\title{
Suzuki Cross-Coupling on Enantiomerically Pure Epoxides: Efficient Synthesis of Diverse, Modular Amino Alcohols from Single Enantiopure Precursors
}

\author{
Xavier Cattoën, Miquel A. Pericàs*
}

Institute of Chemical Research of Catalonia (ICIQ), Av. Països Catalans, 16. 43007 Tarragona, Spain, and Departament de Química Orgànica, Universitat de Barcelona (UB), 08028 Barcelona, Spain.

\section{Supporting information Contents}

NMR and IR spectra of 2a-2d, 3aa-3ag, 5aa-5ag, Precursor of 6, 6, 7a-d, 8aa-ag, 9aa-ag and 10..................................................S2-S131 


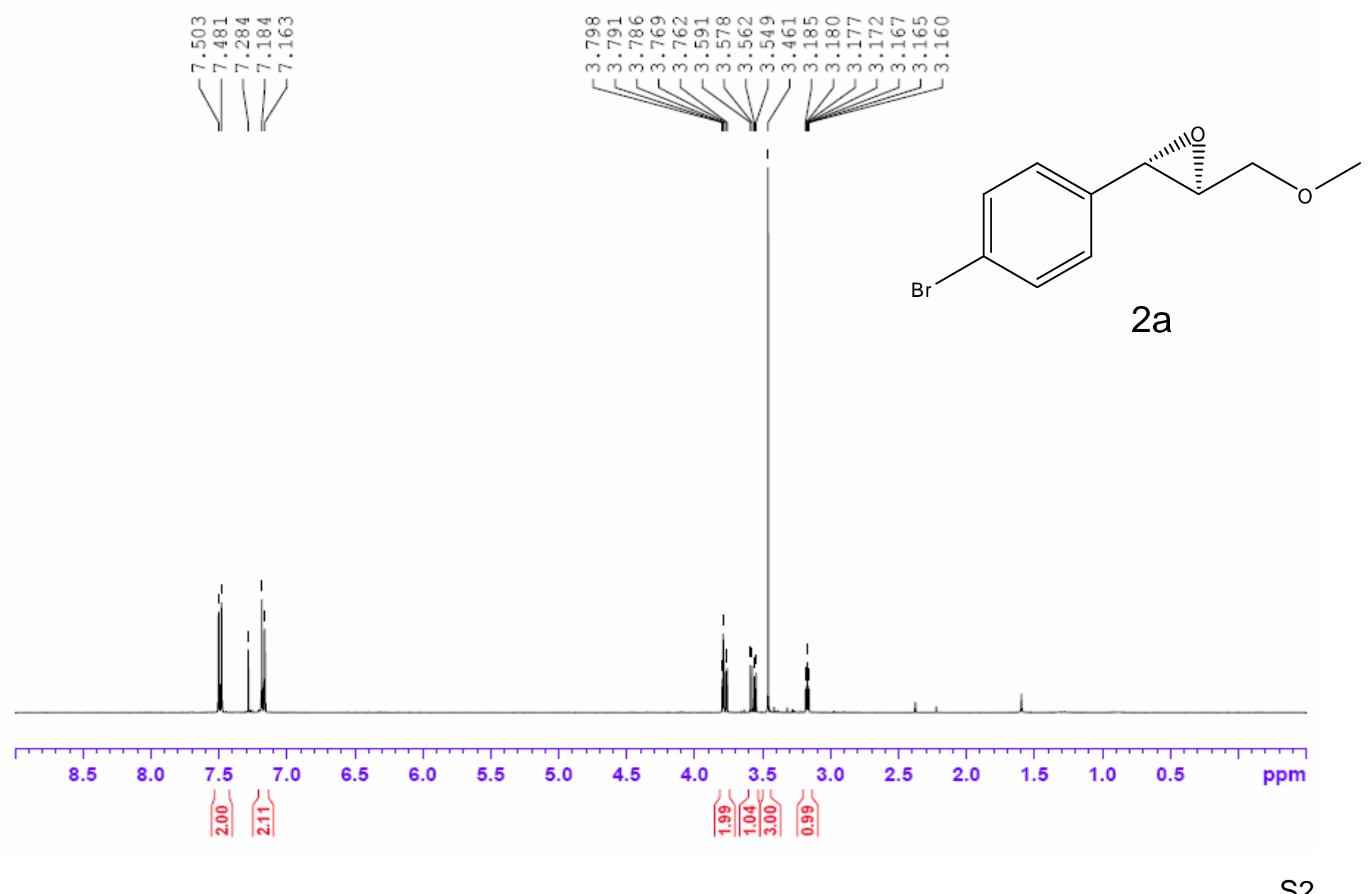




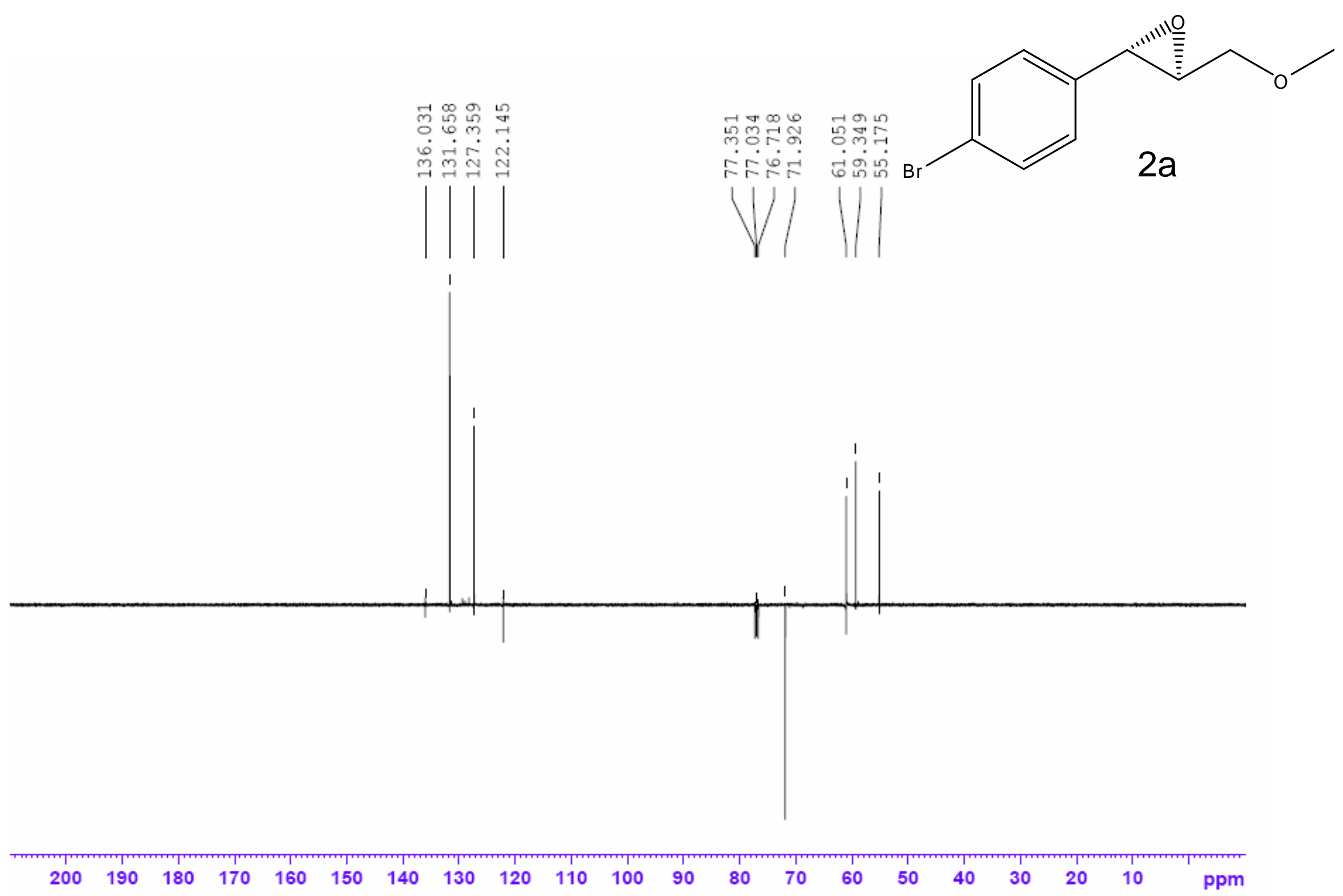




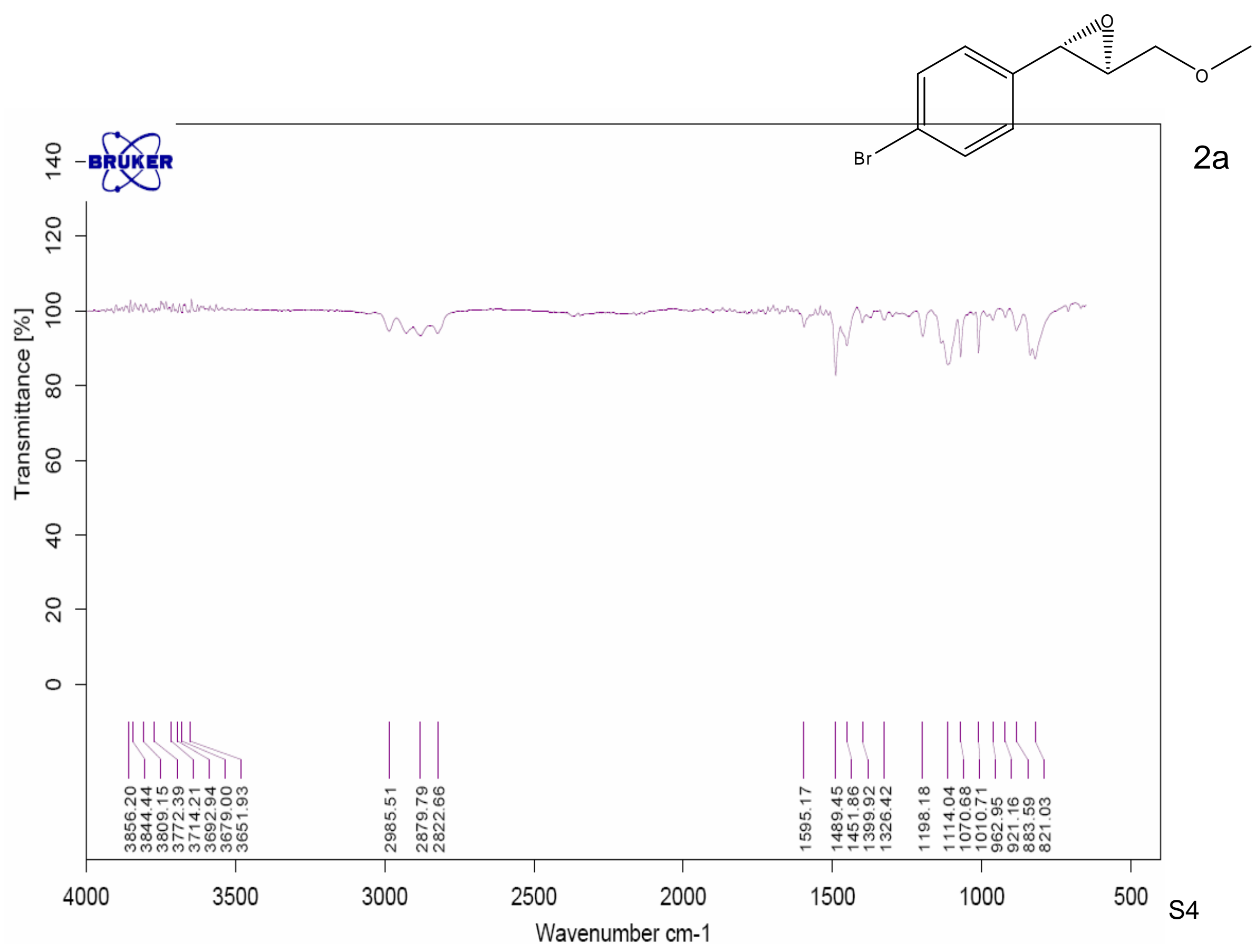




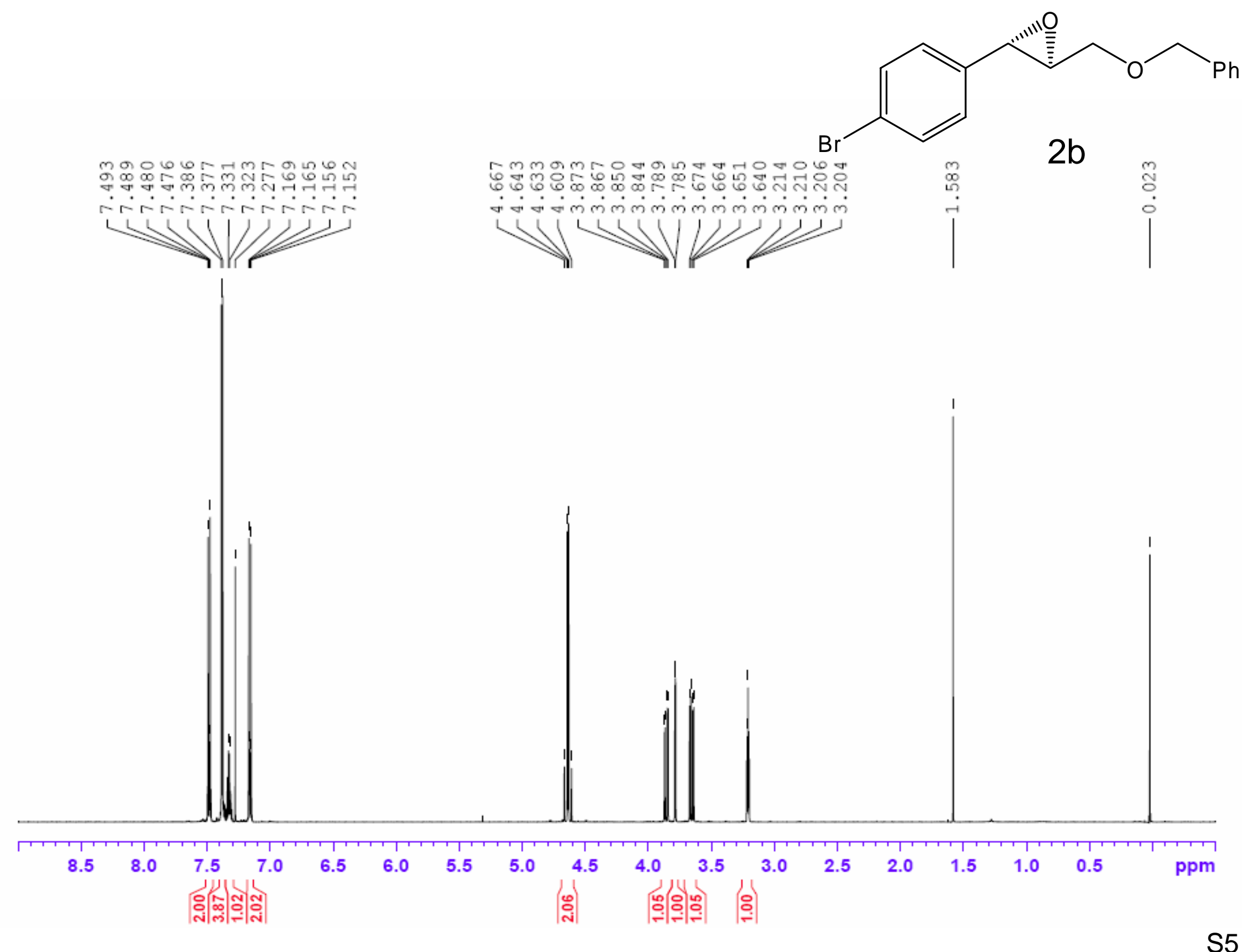




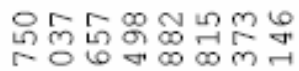

-

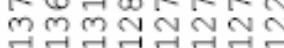

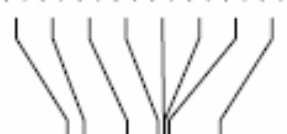

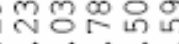

हित्रलं

VI
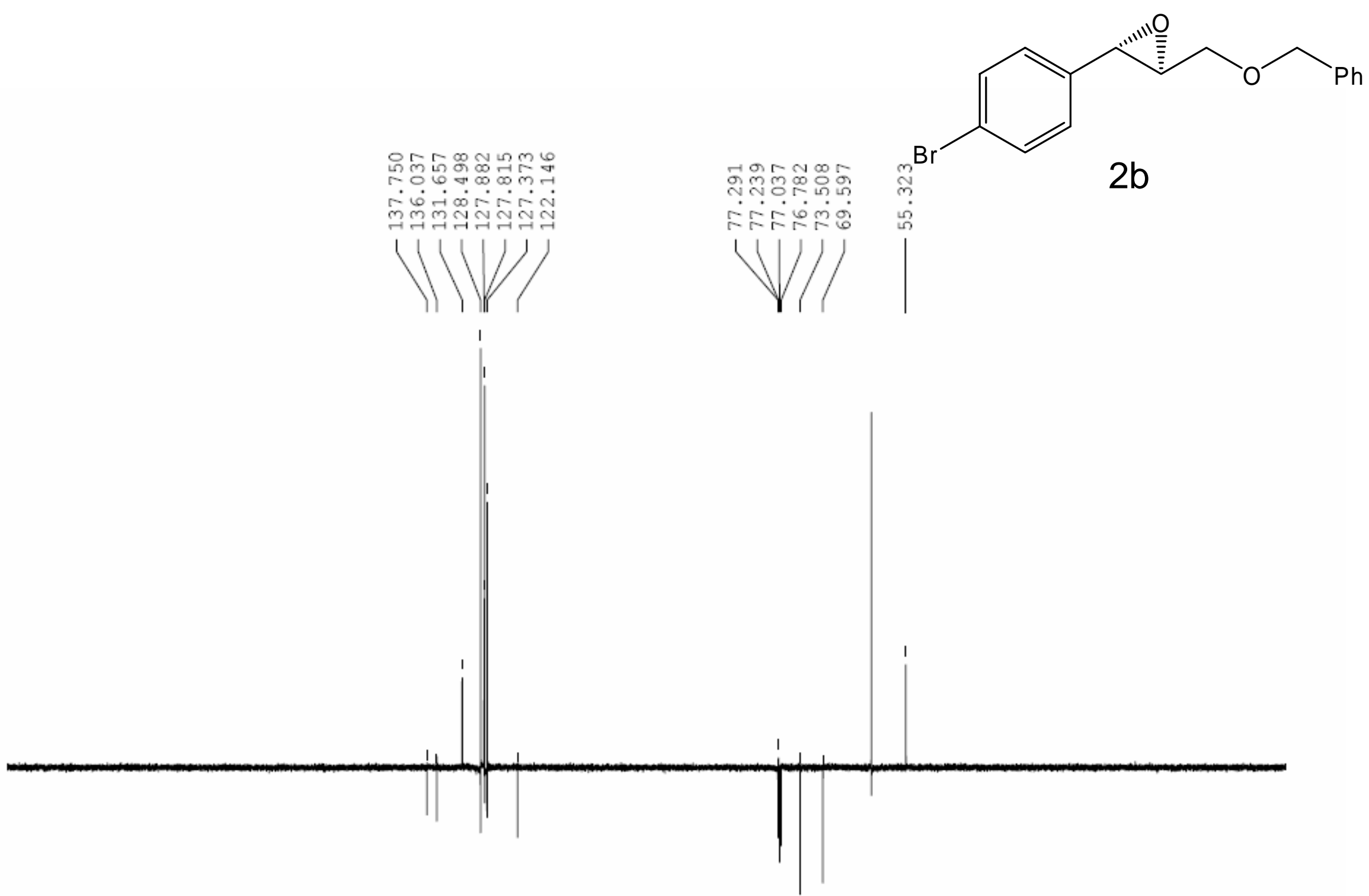


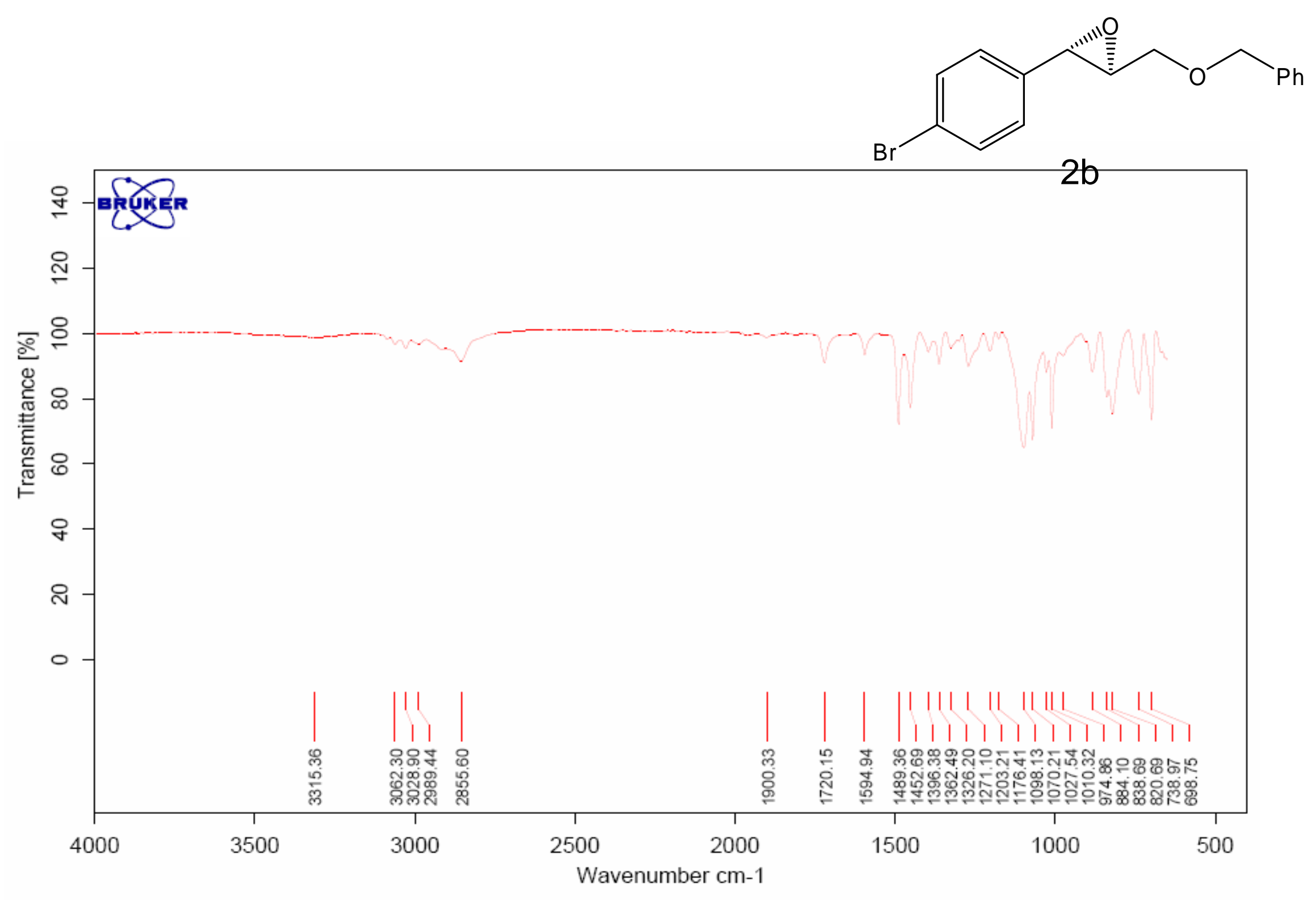




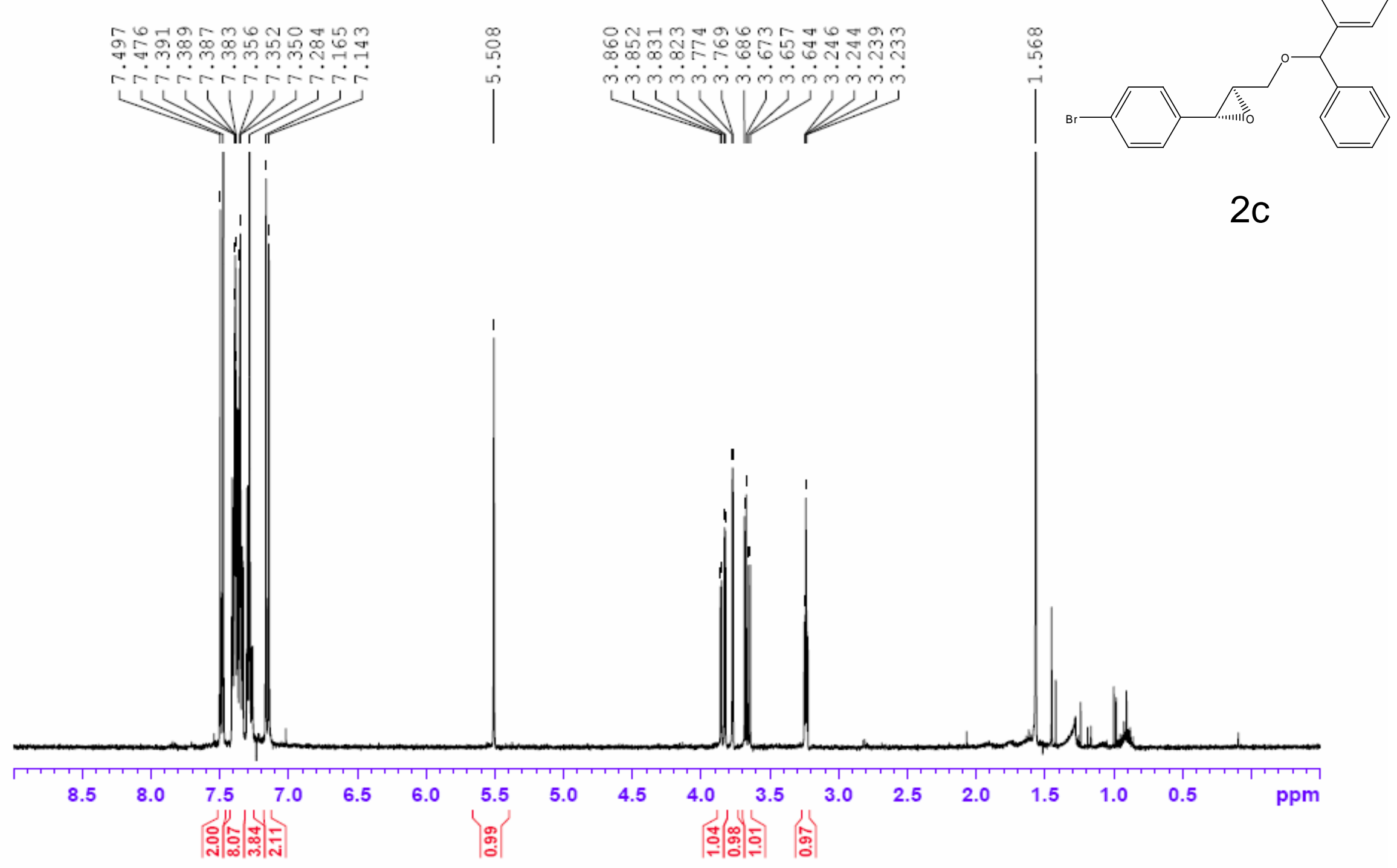




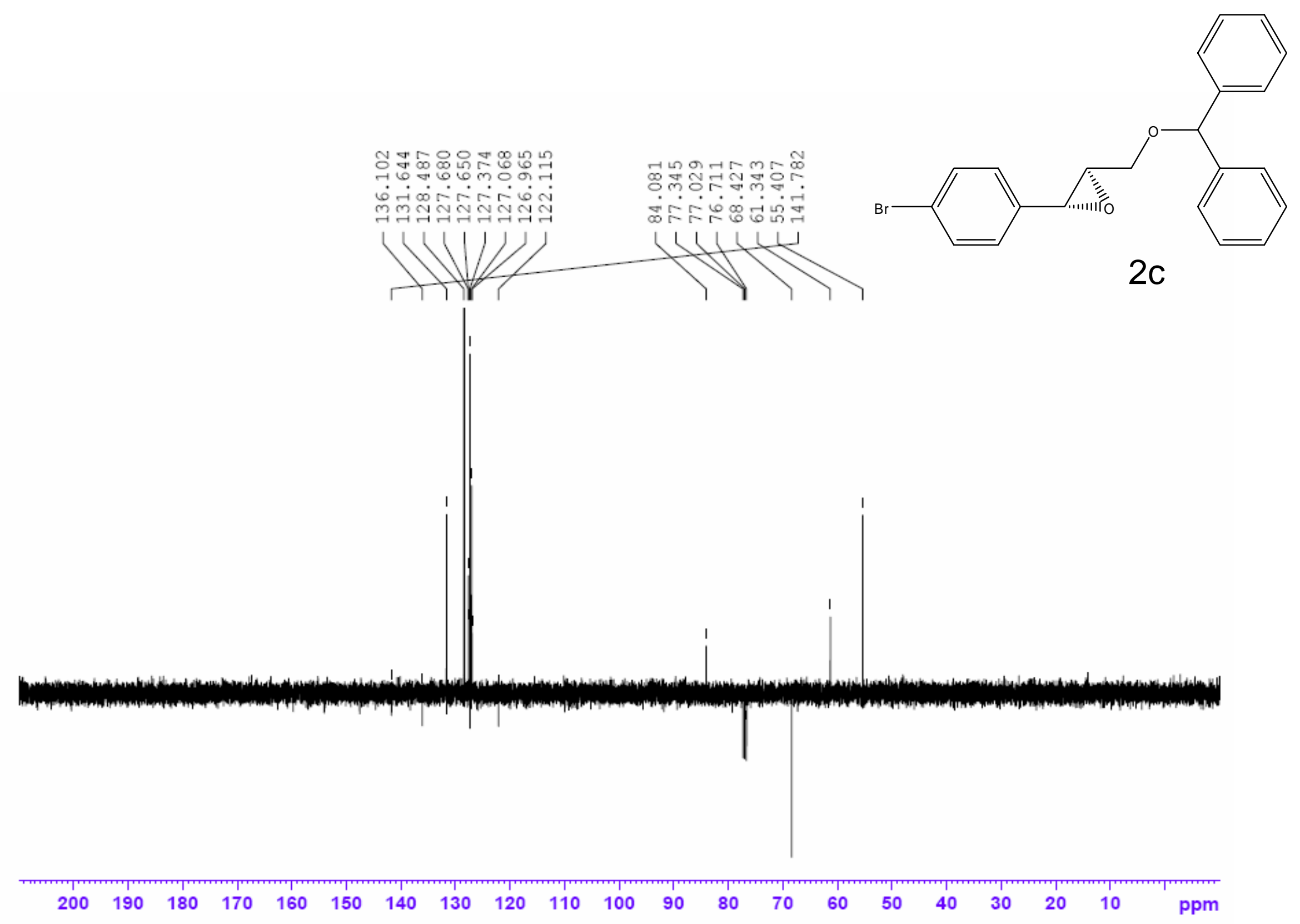




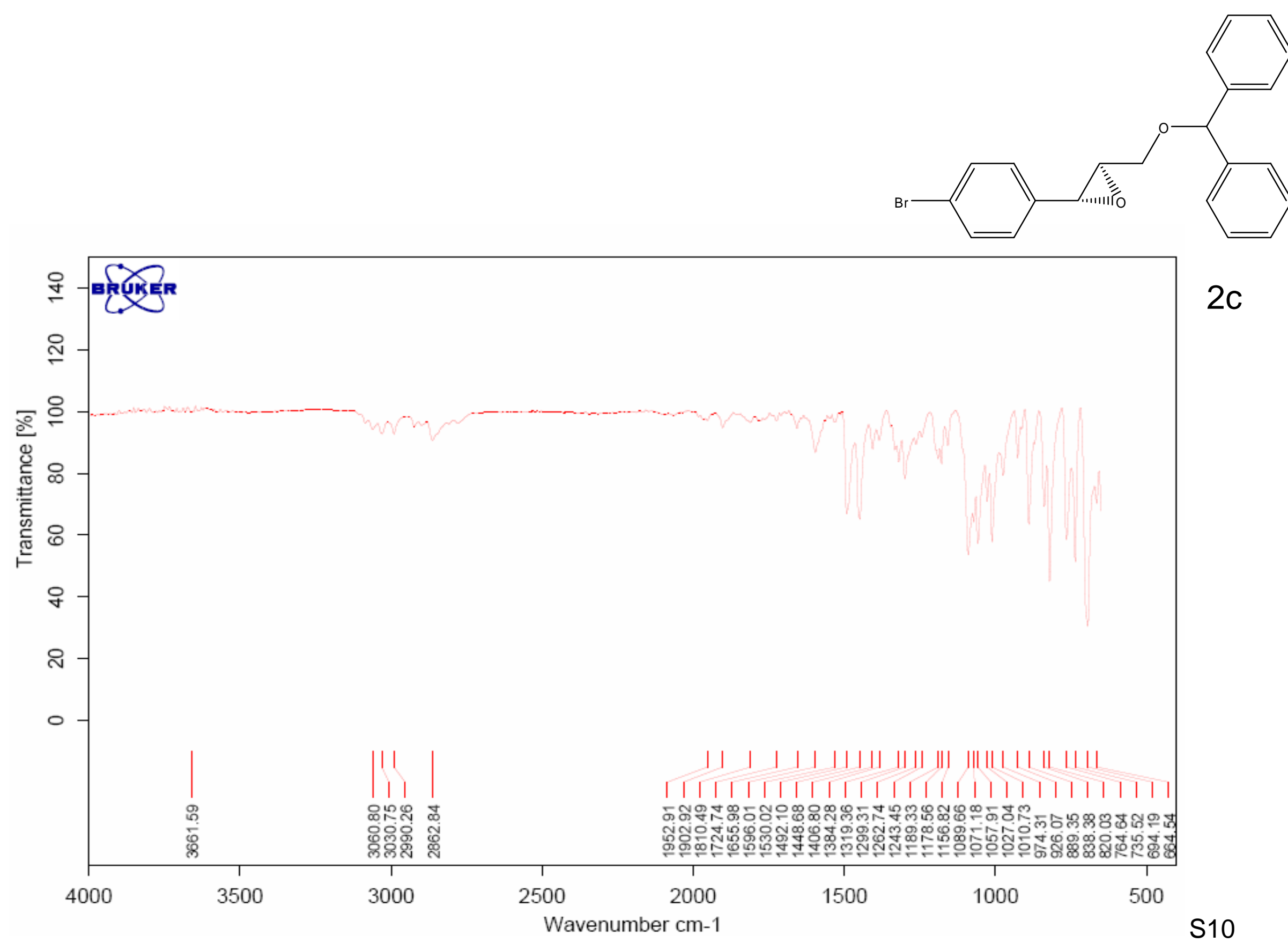




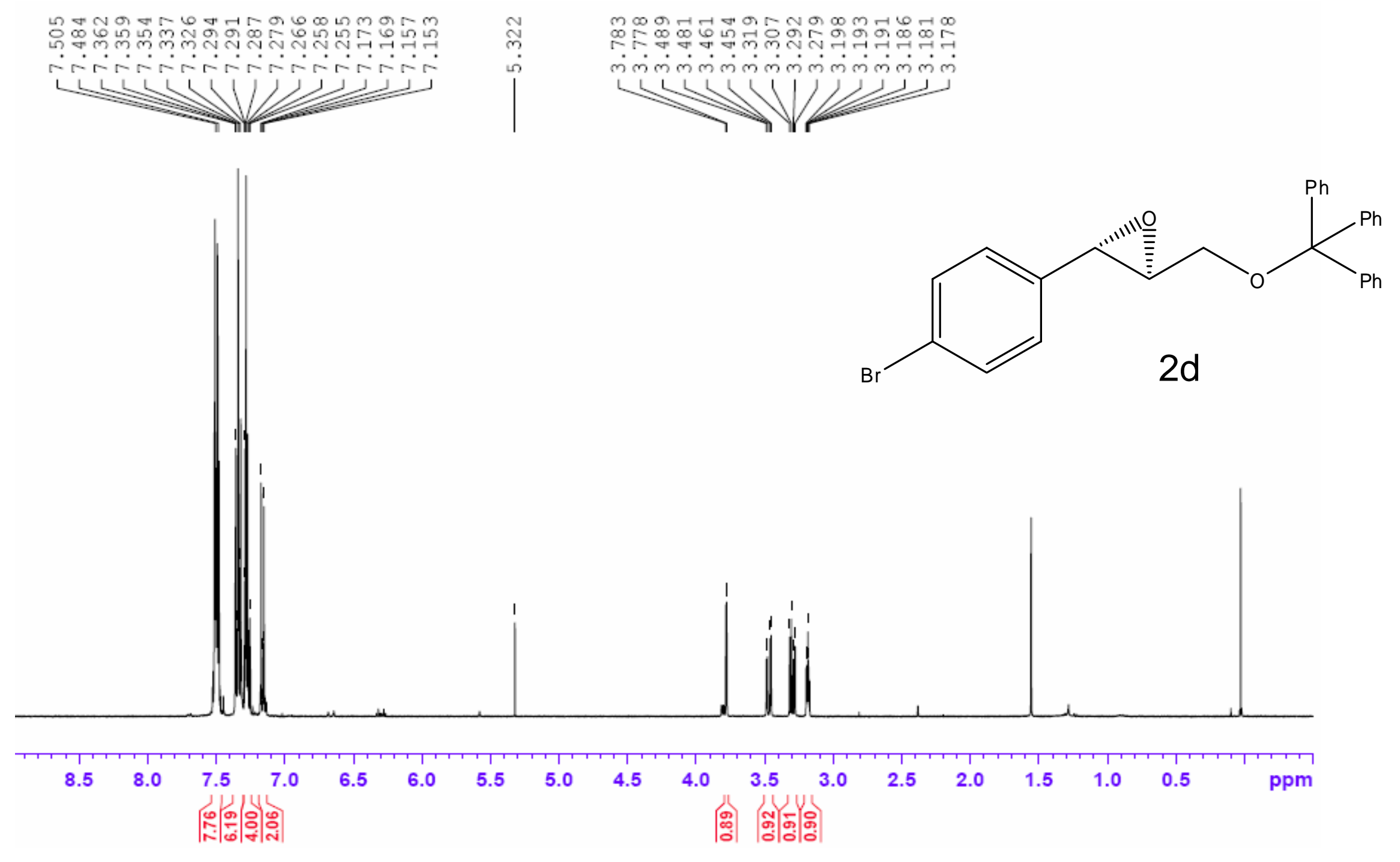




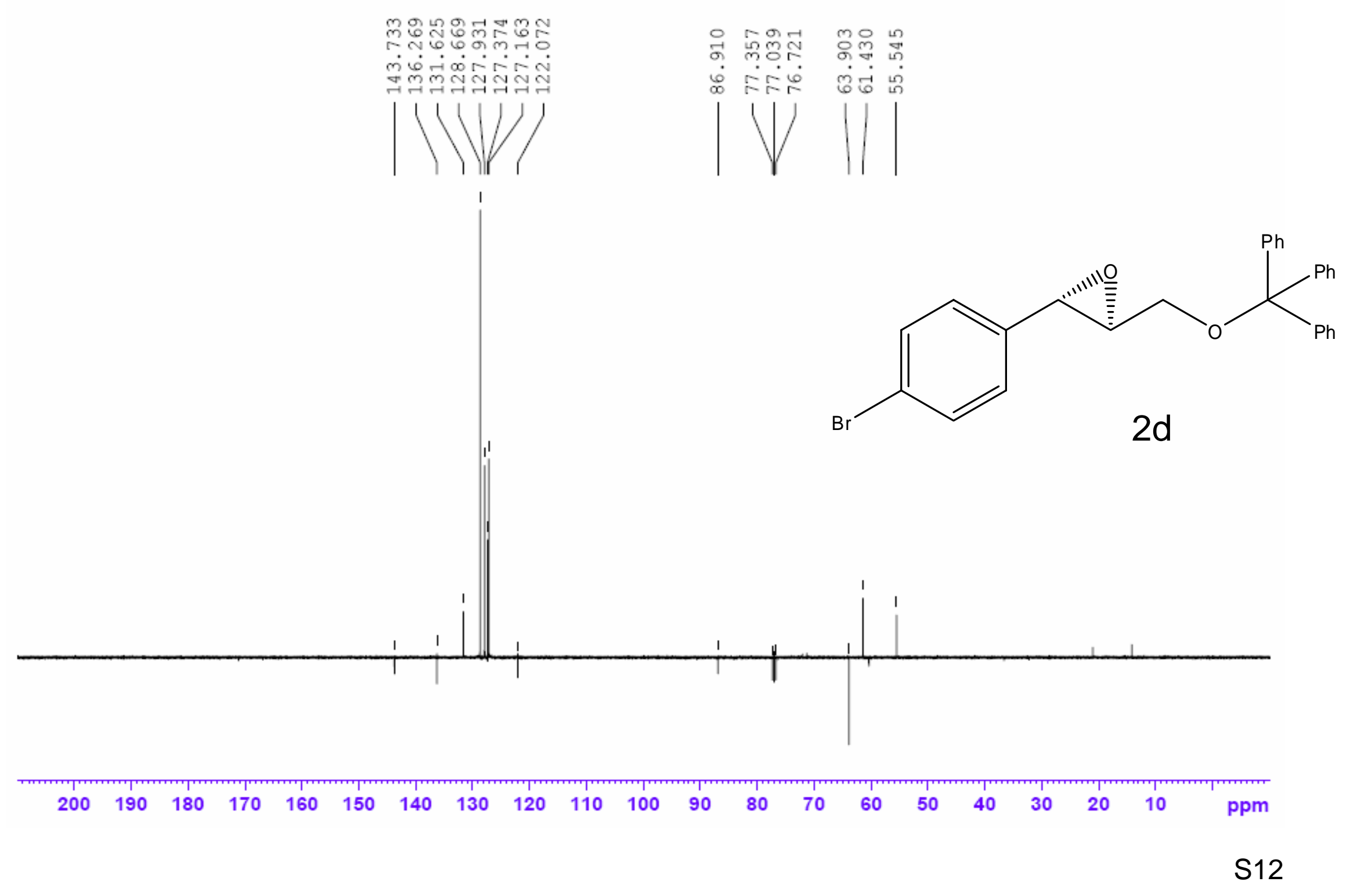



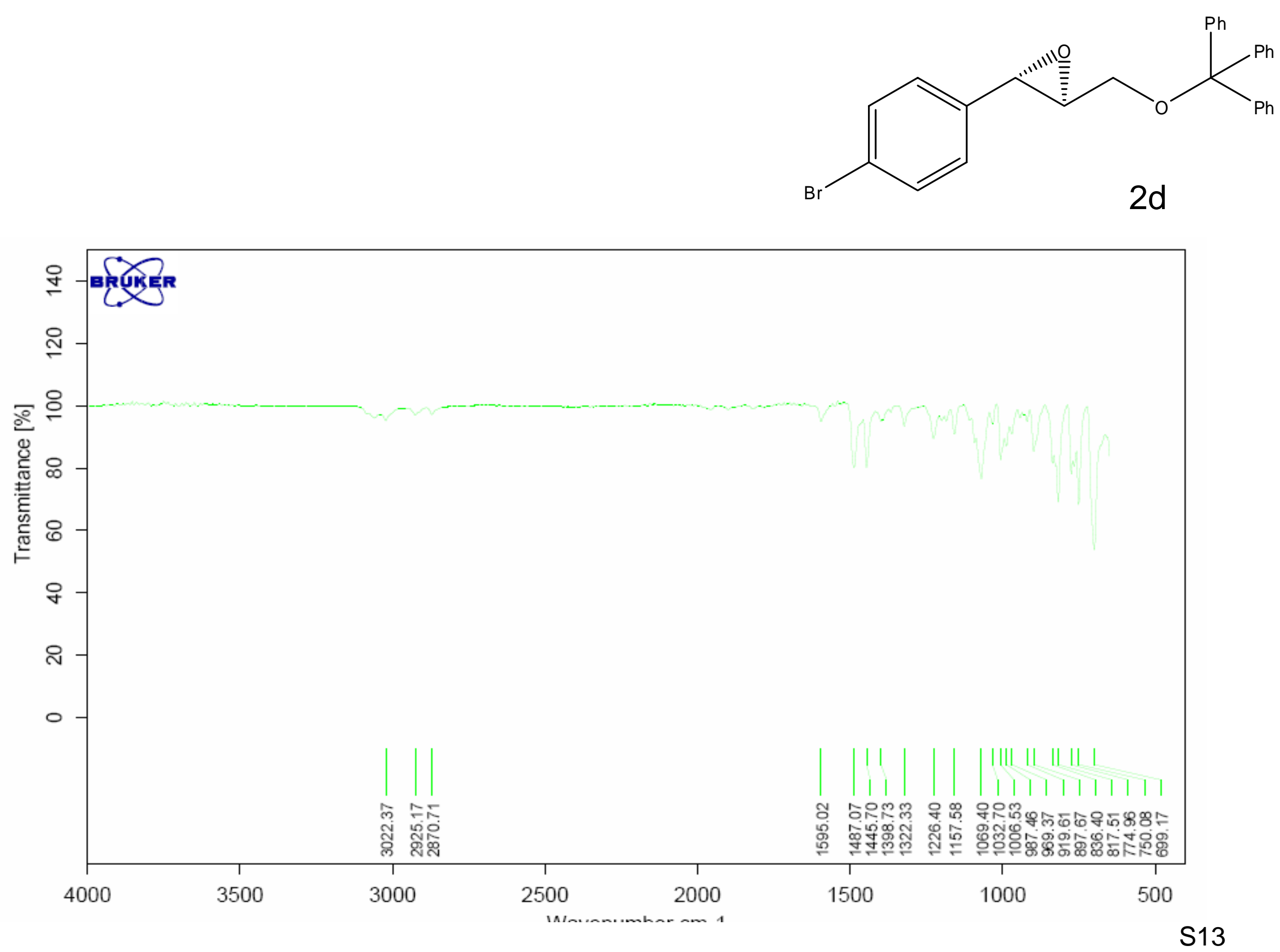


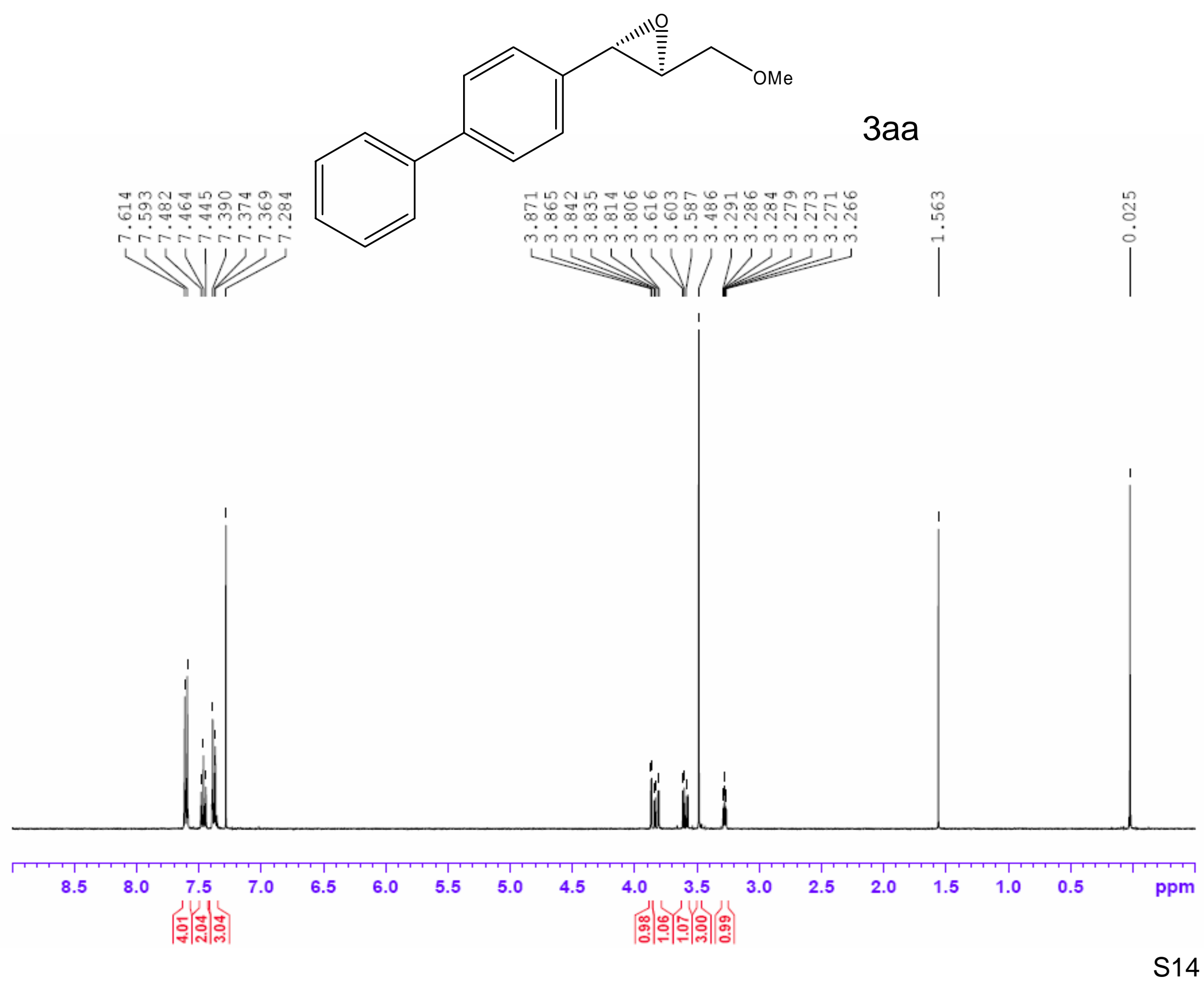




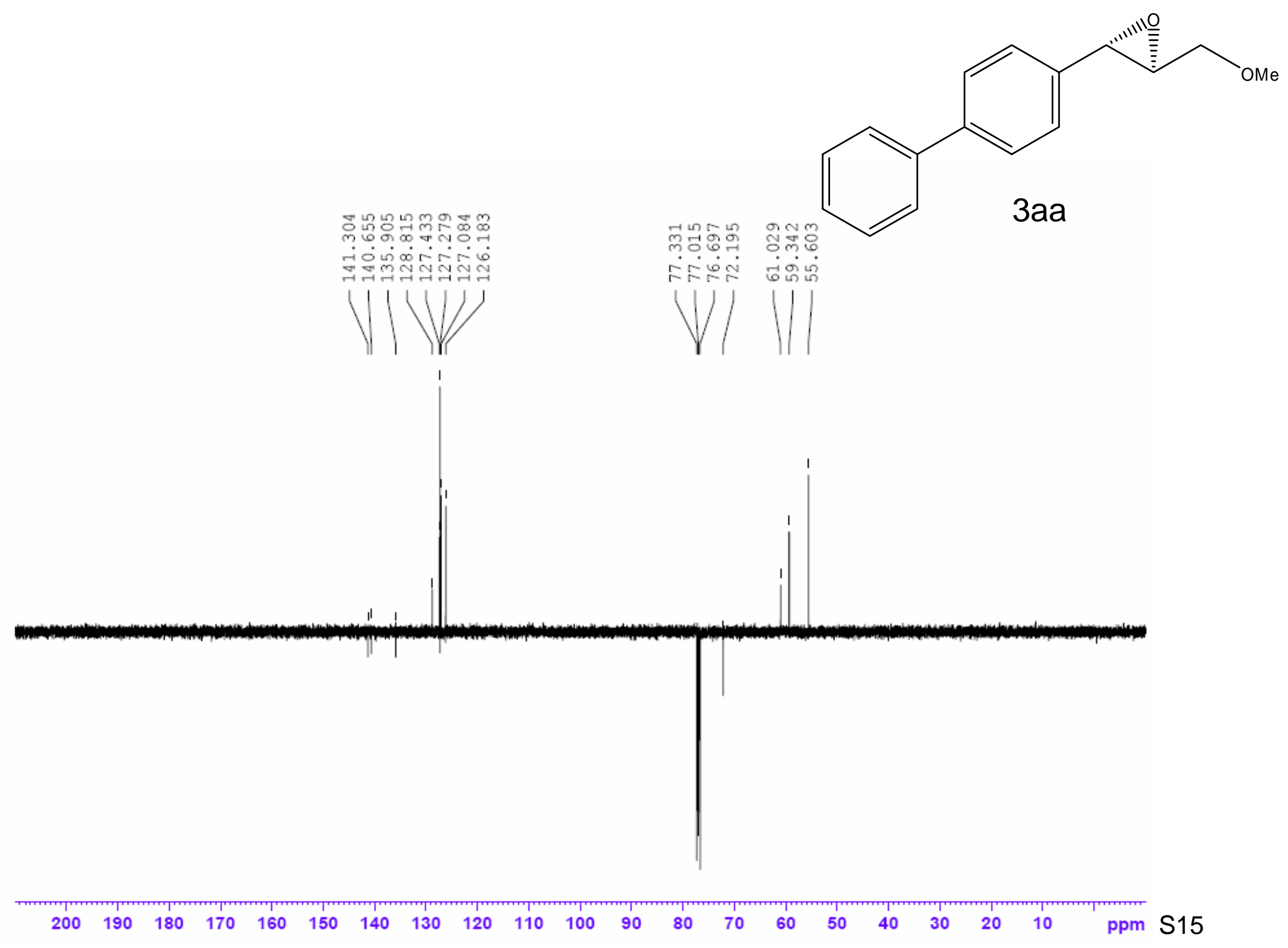




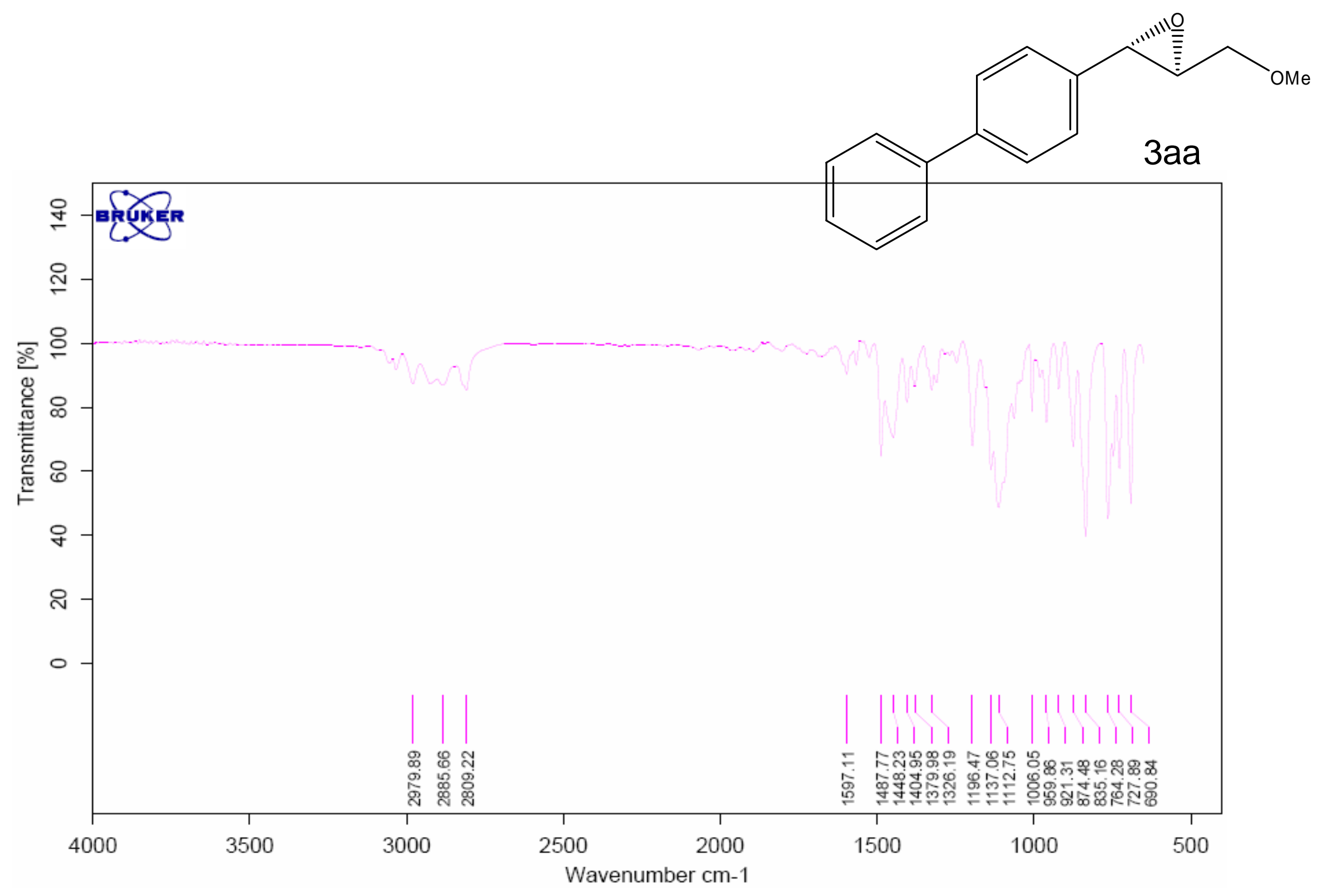




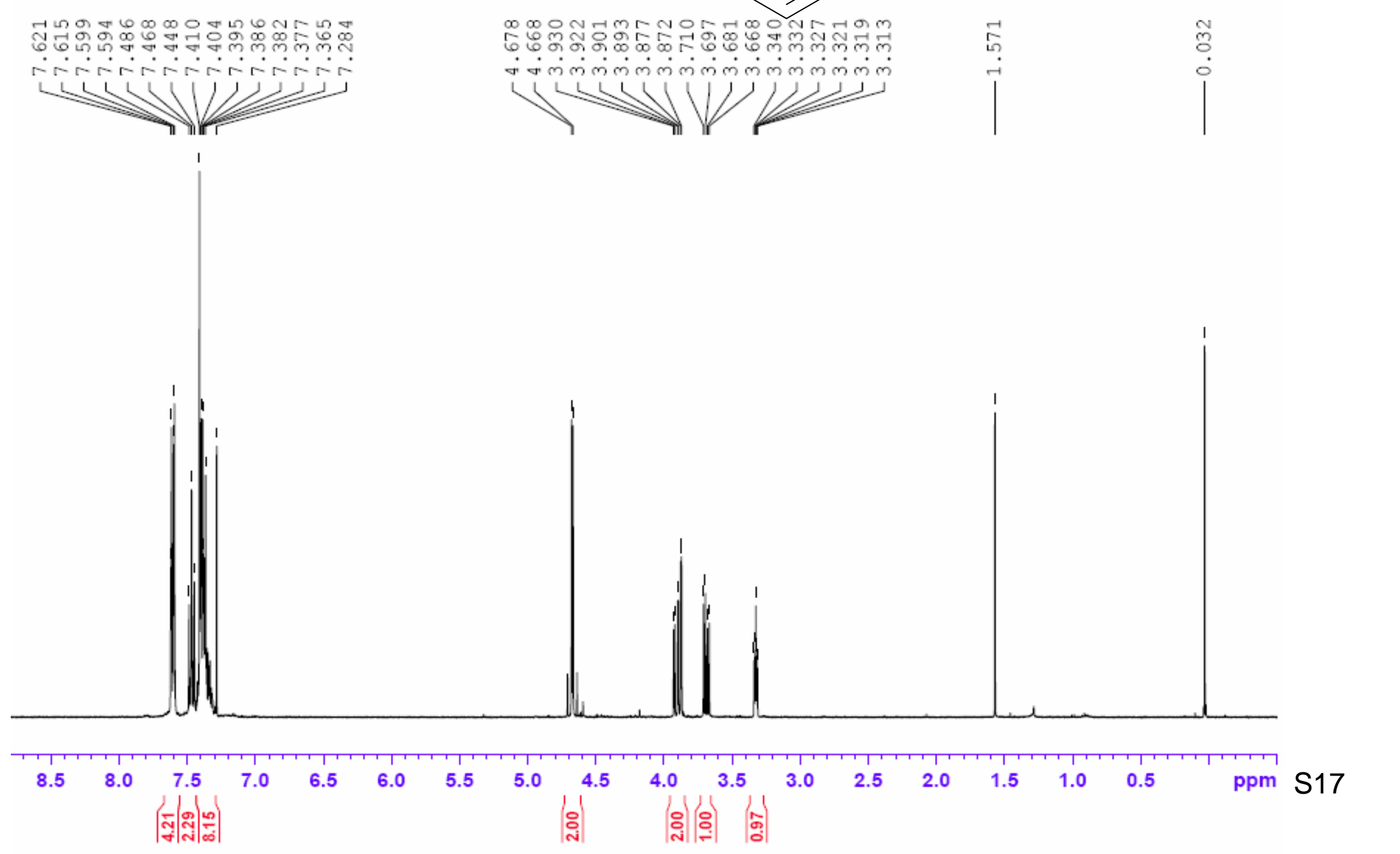




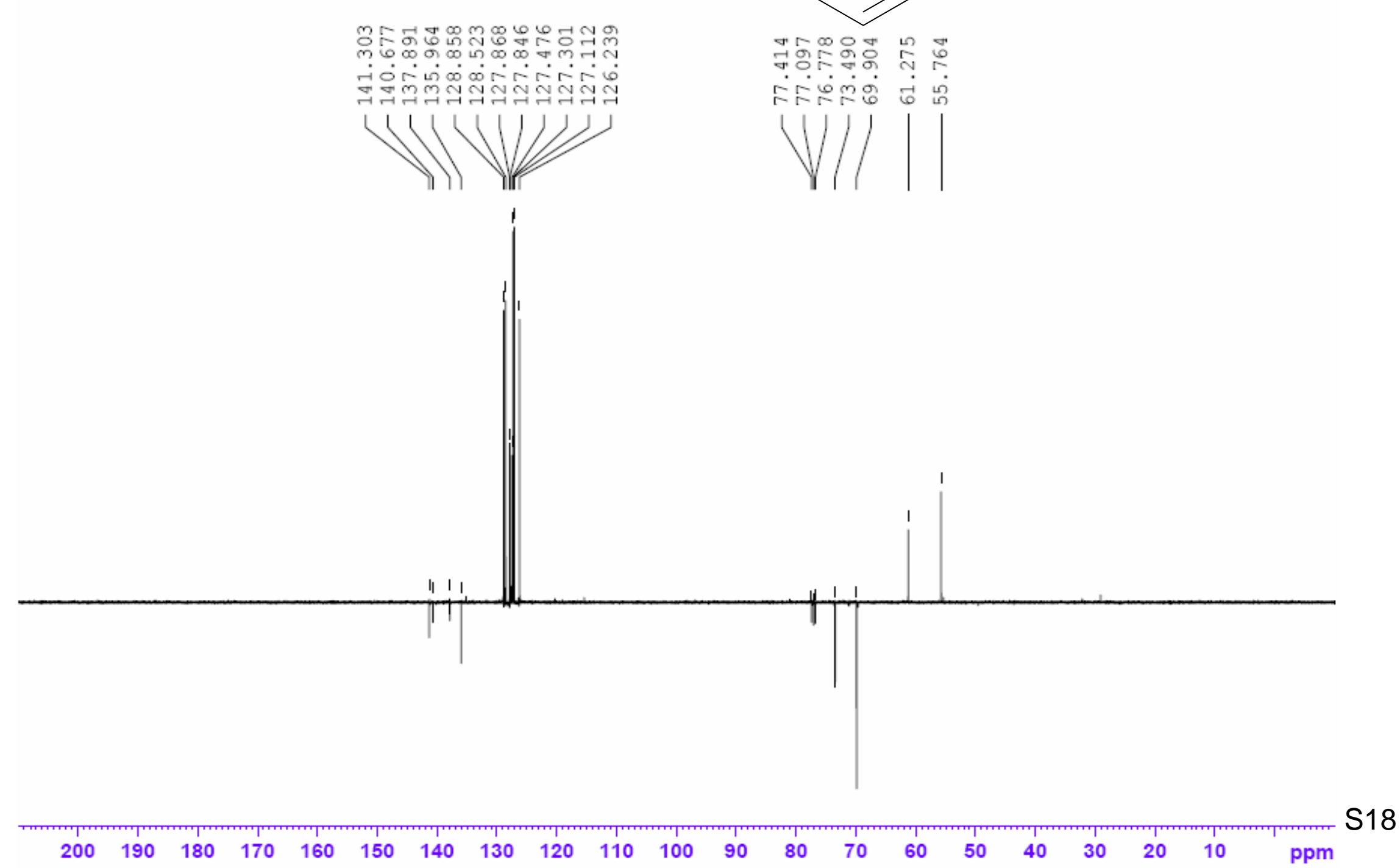




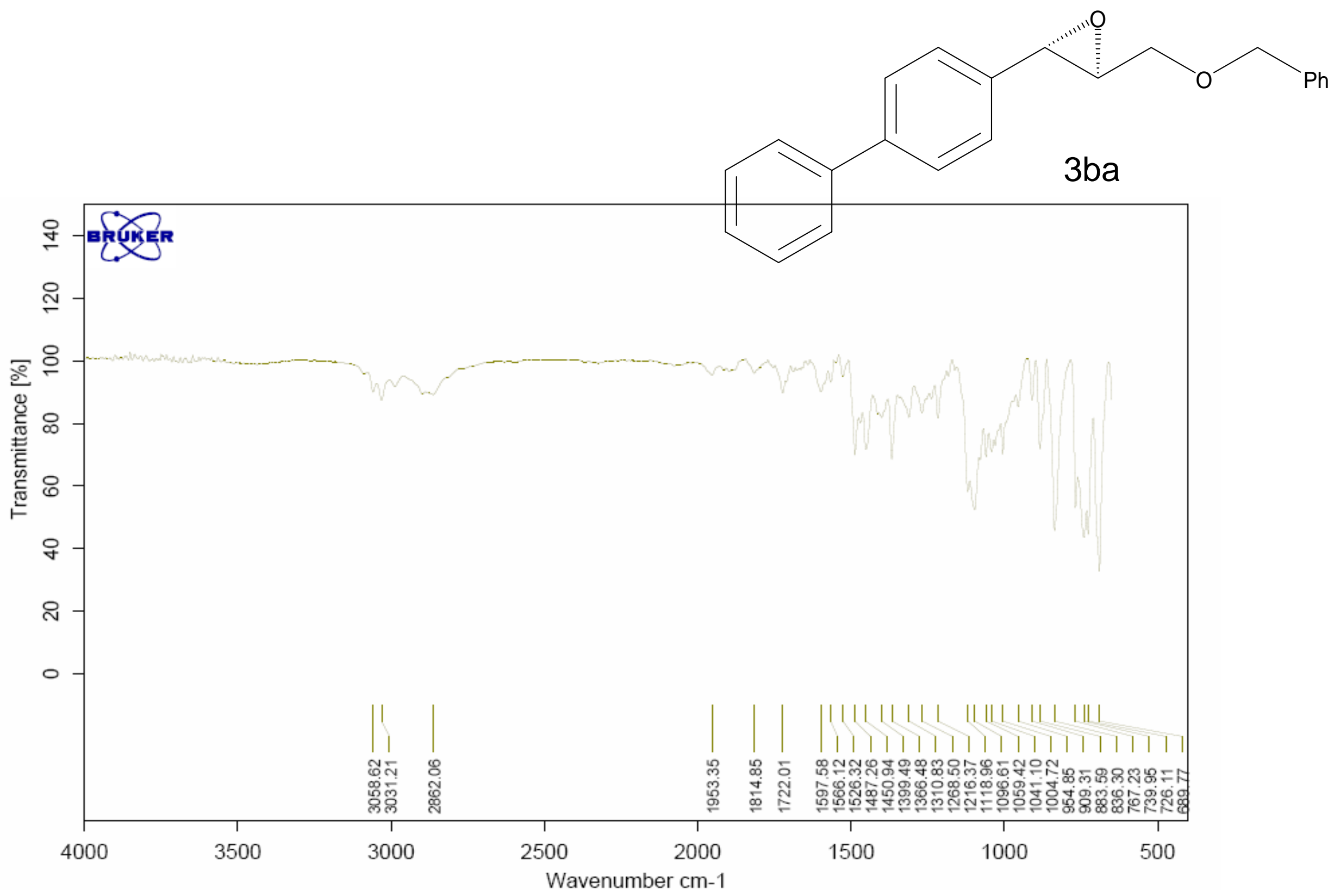




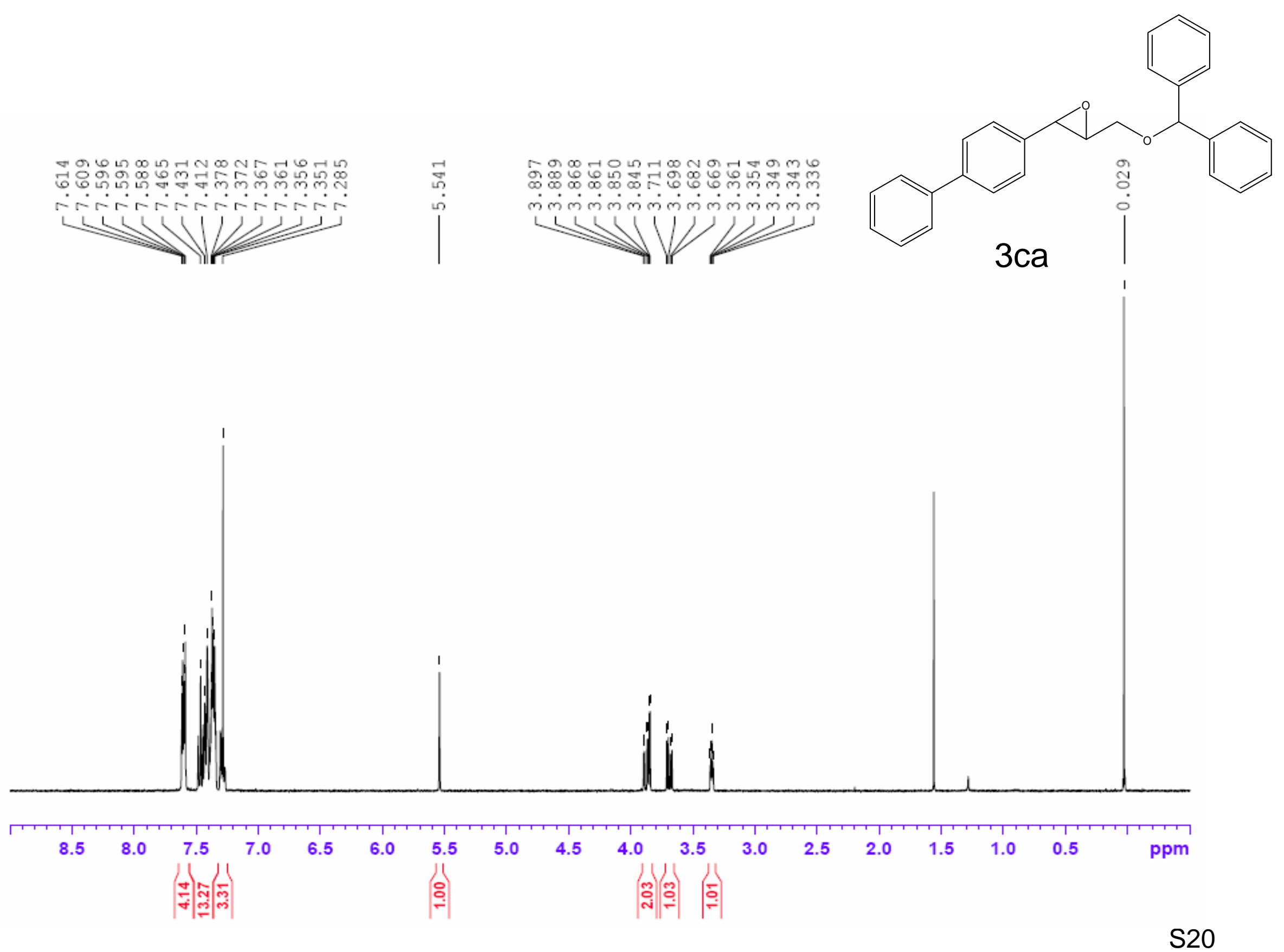




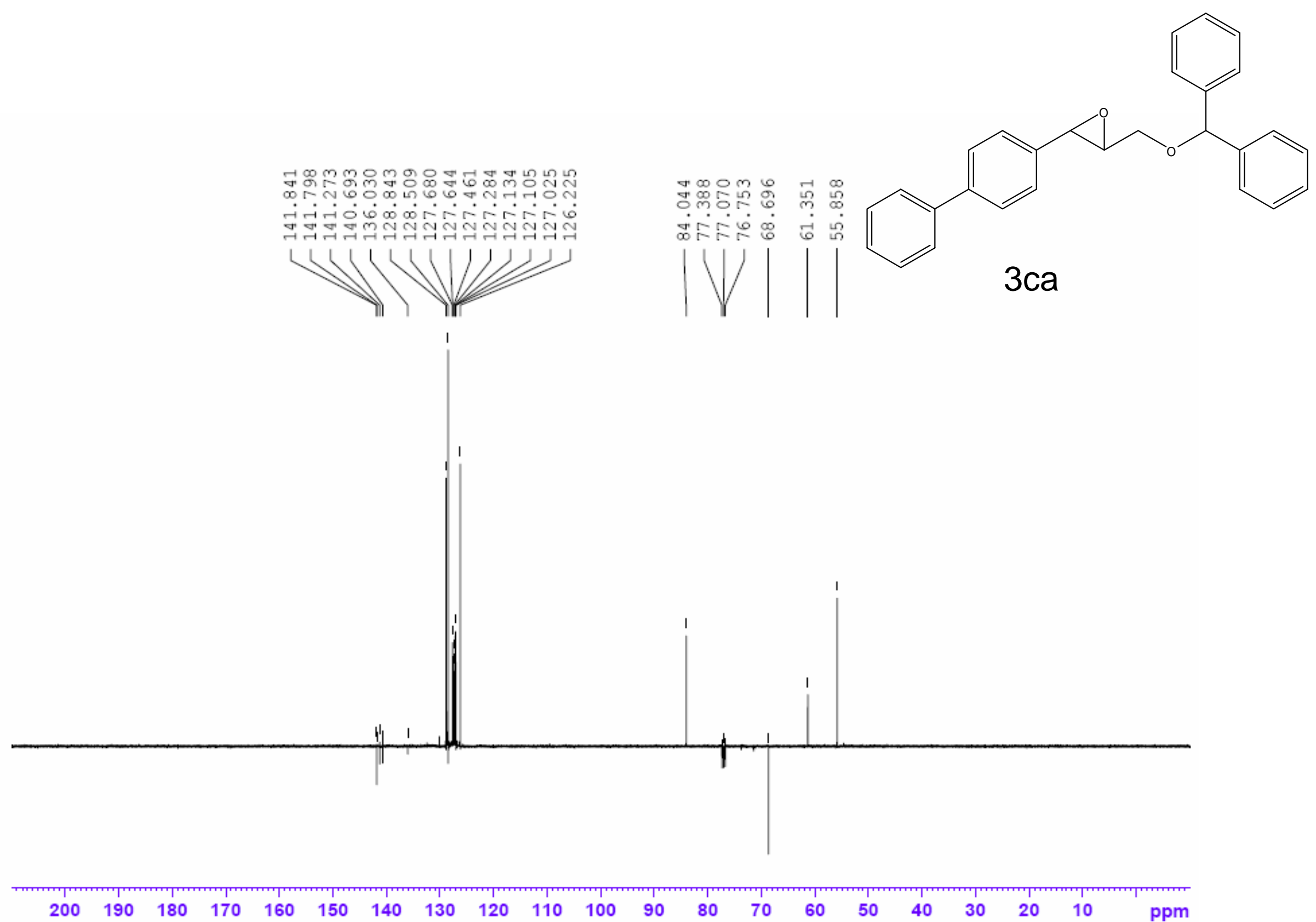




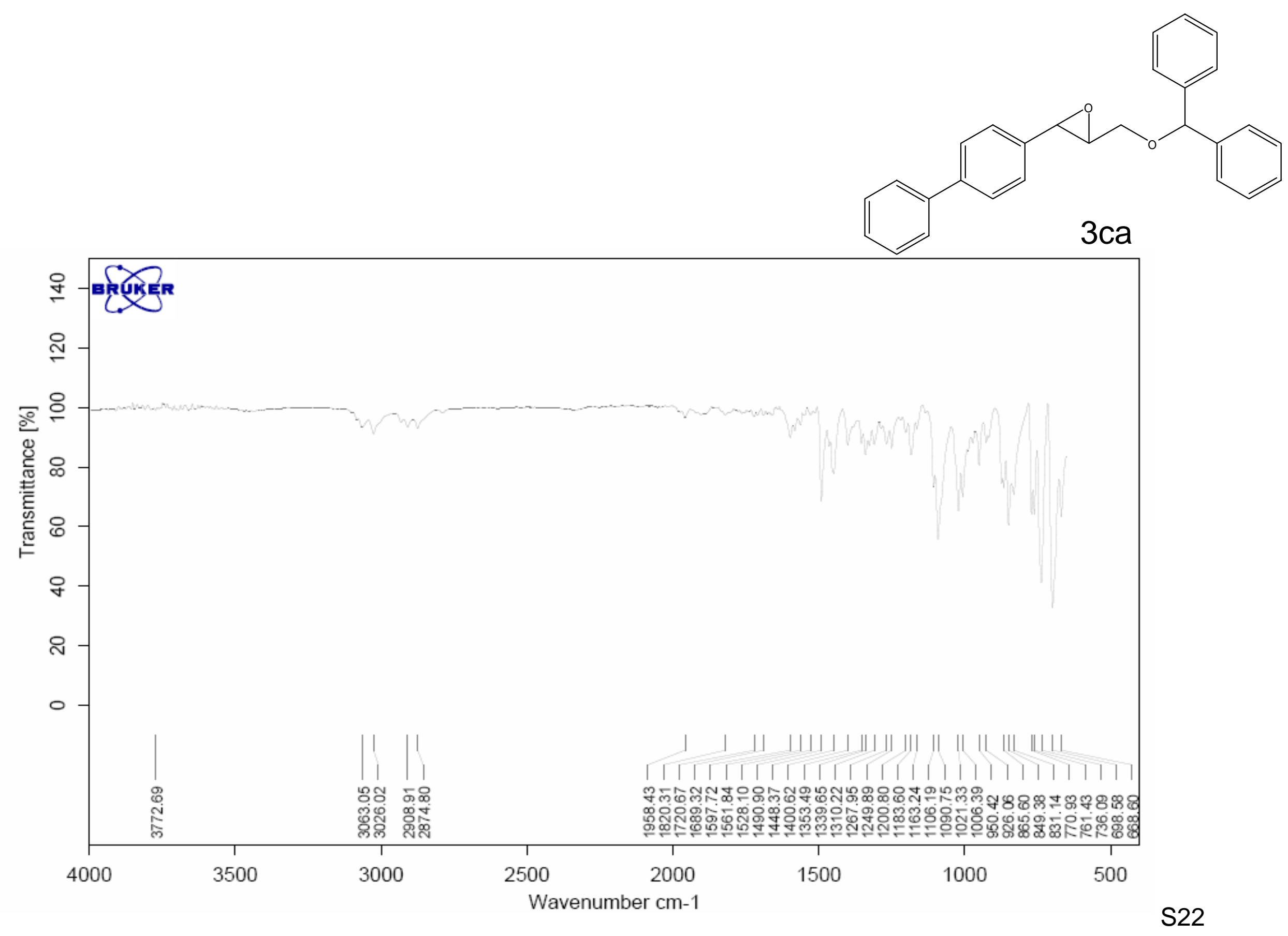



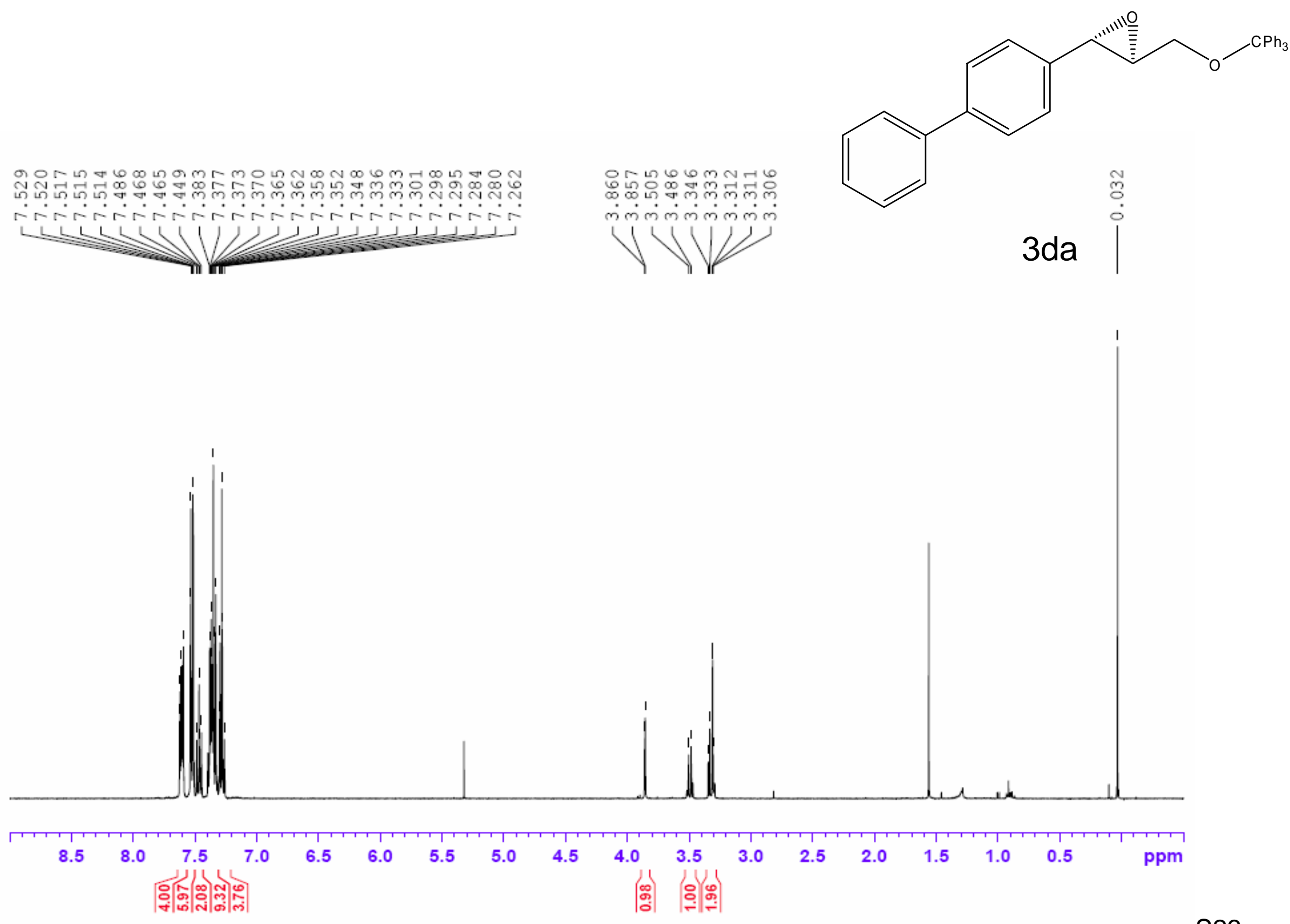

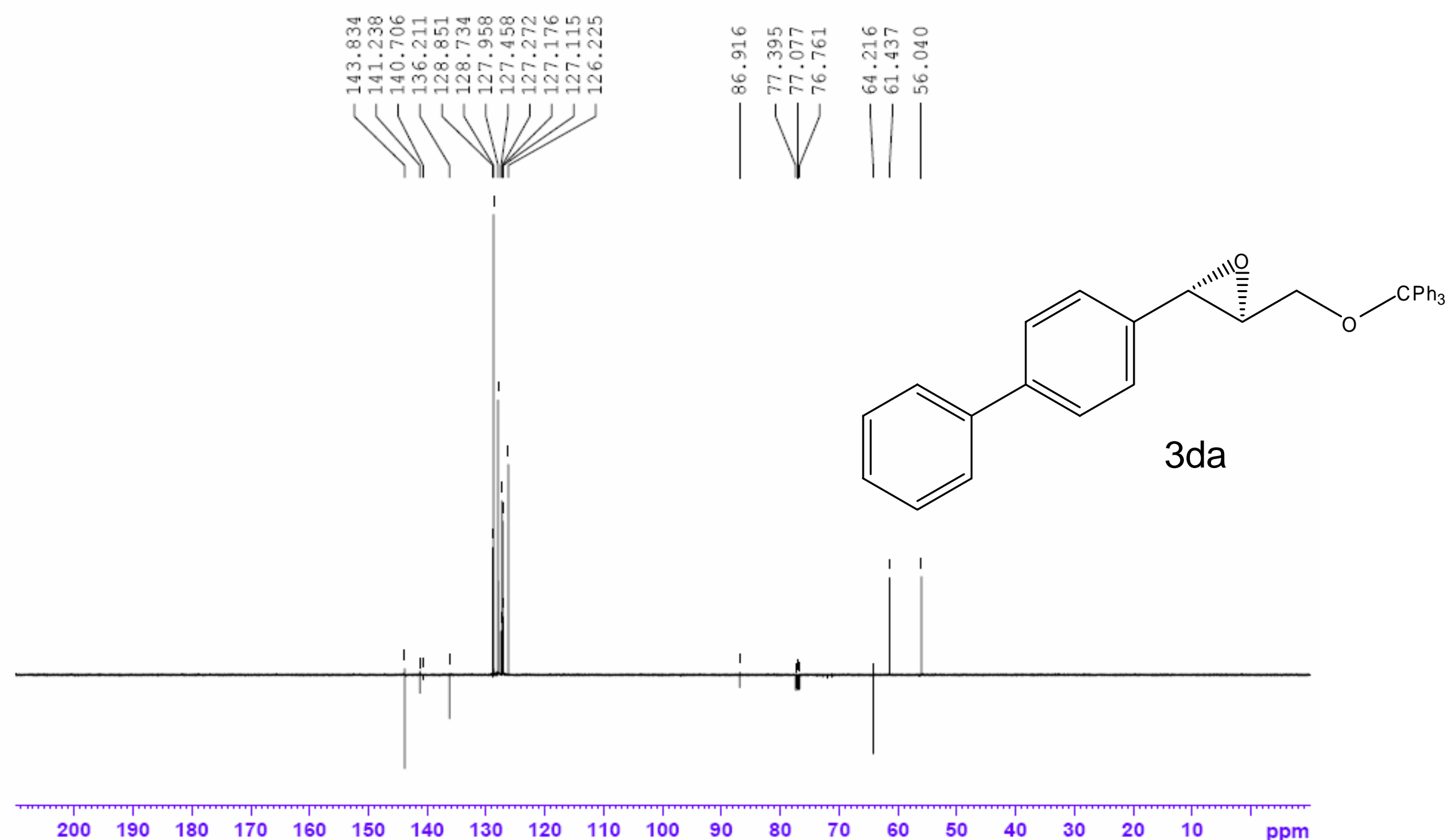


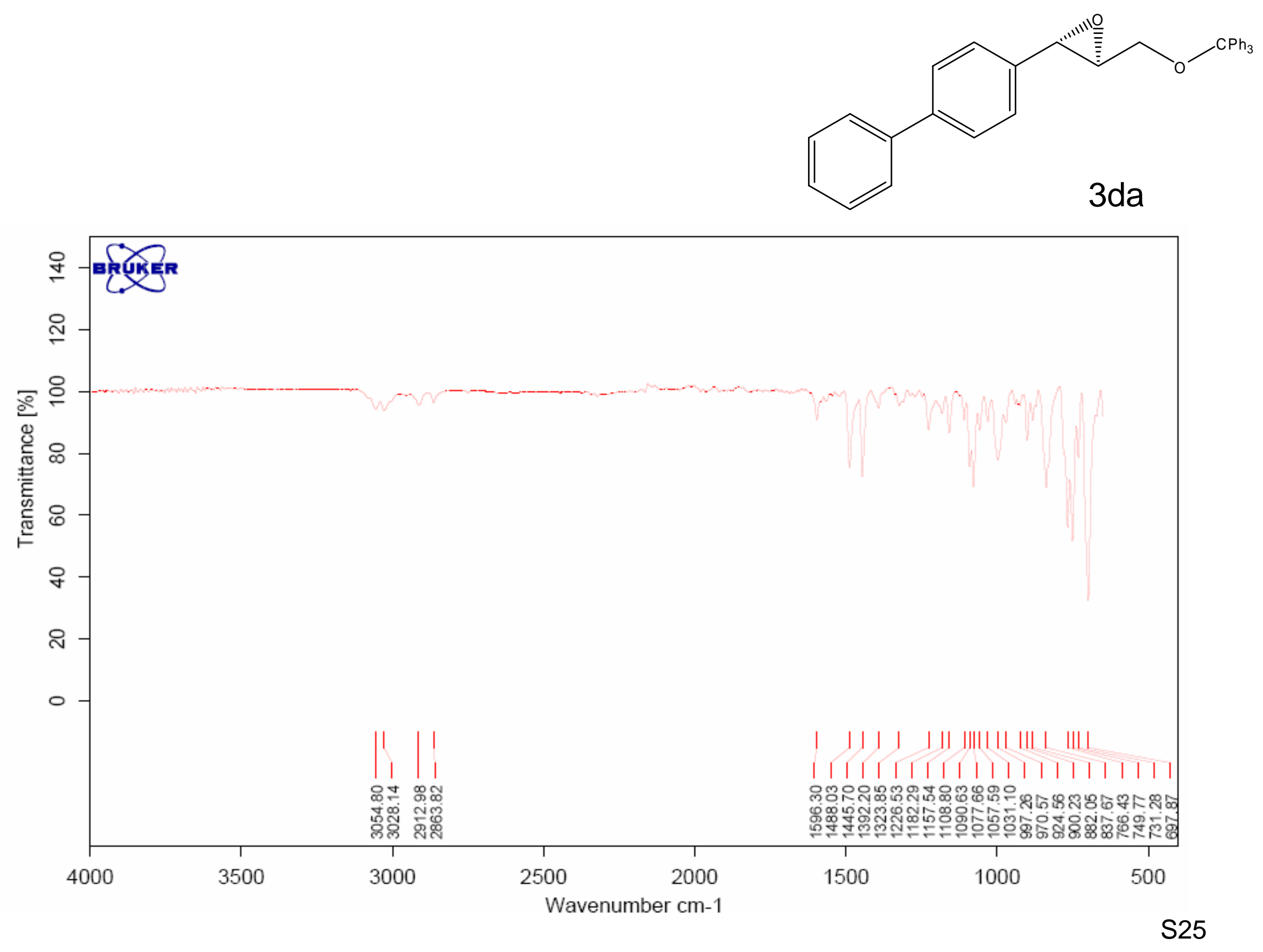




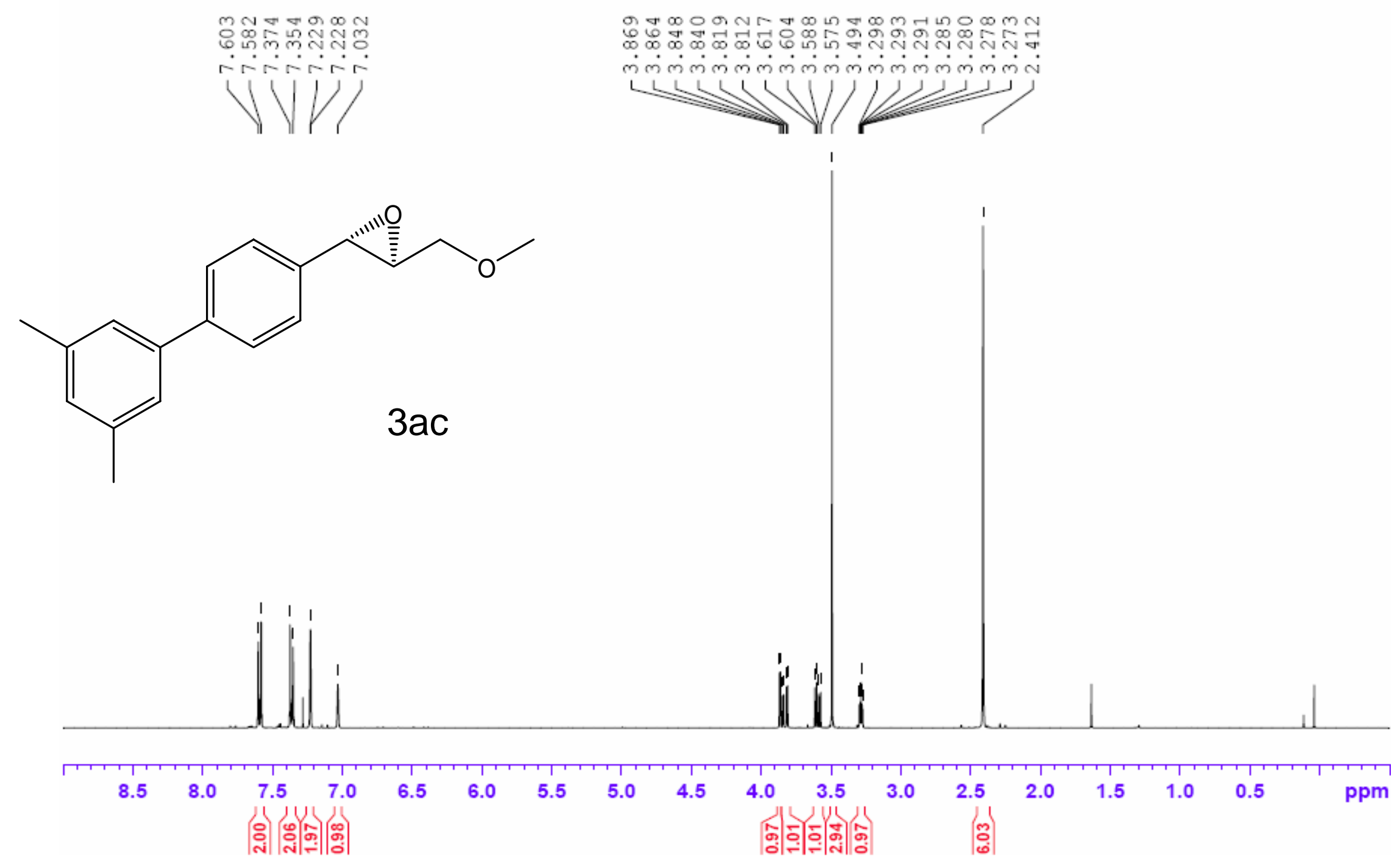




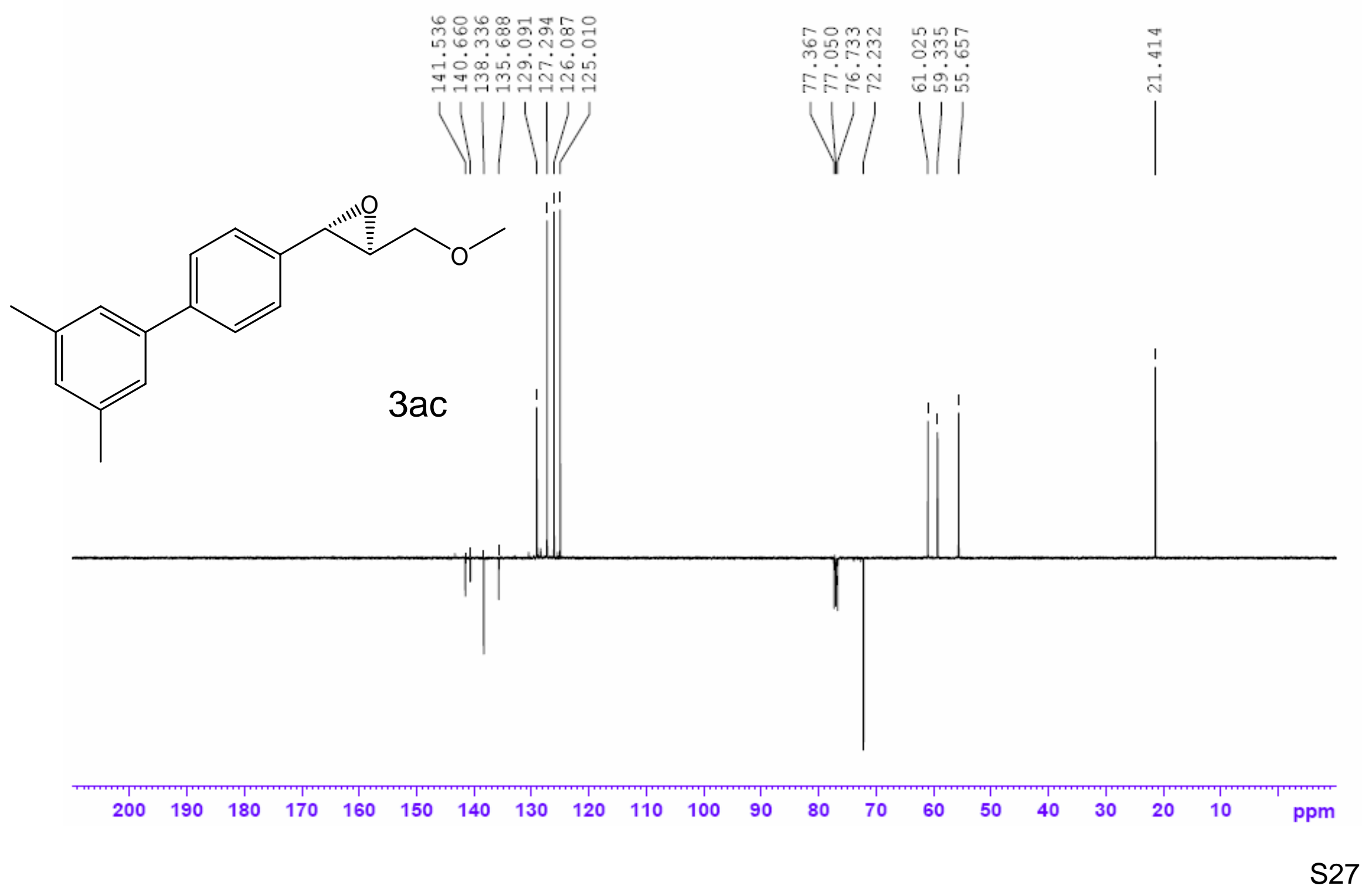




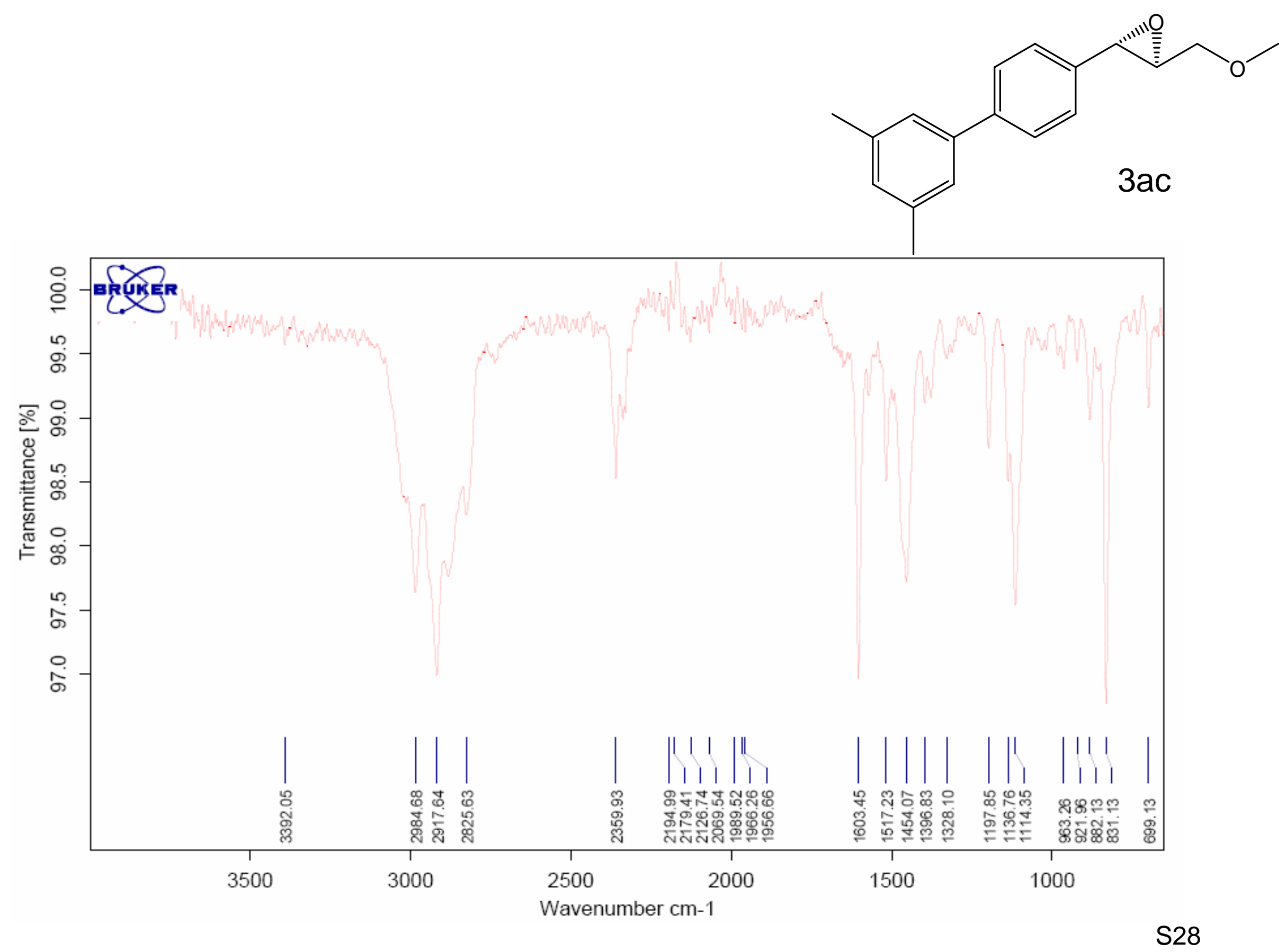




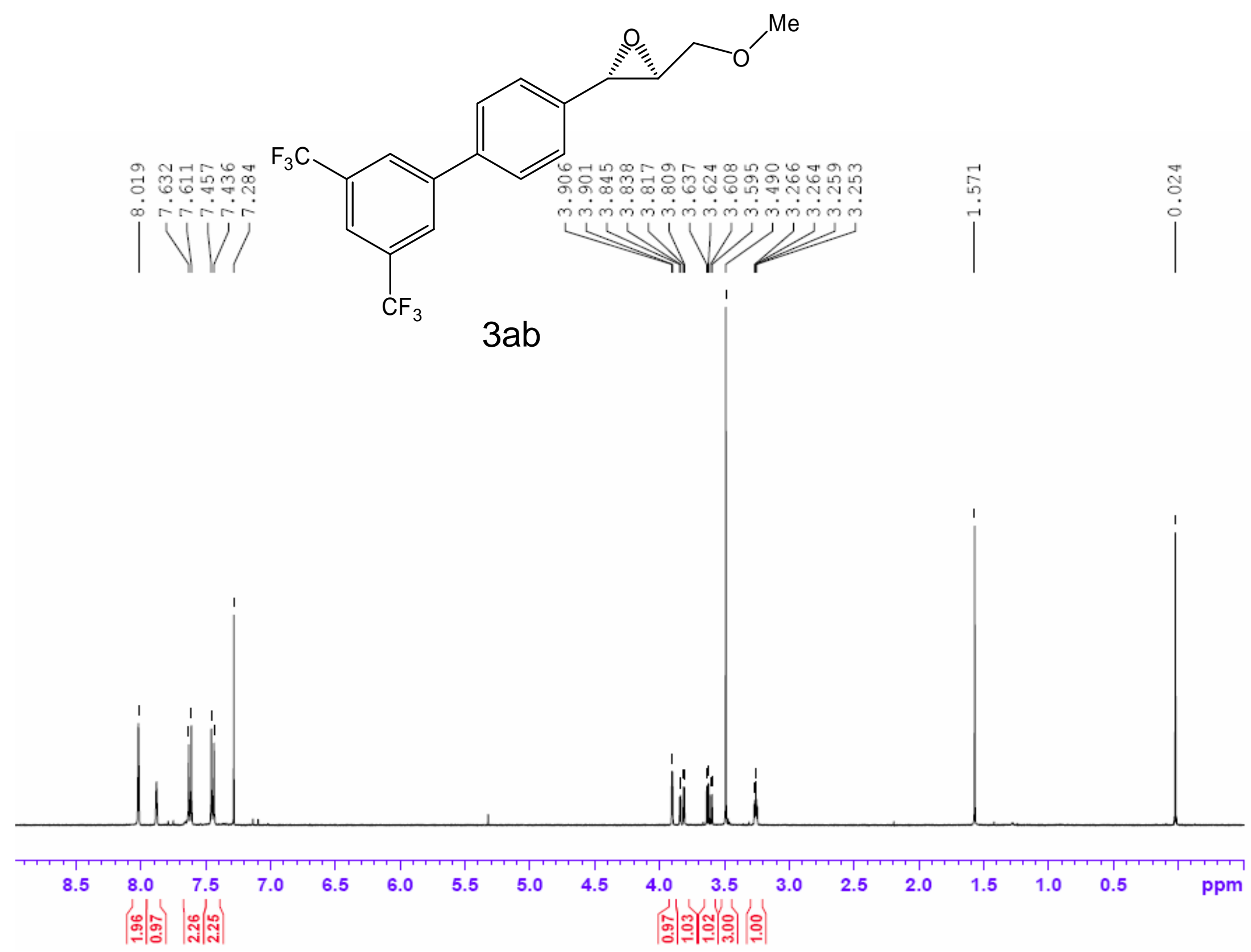




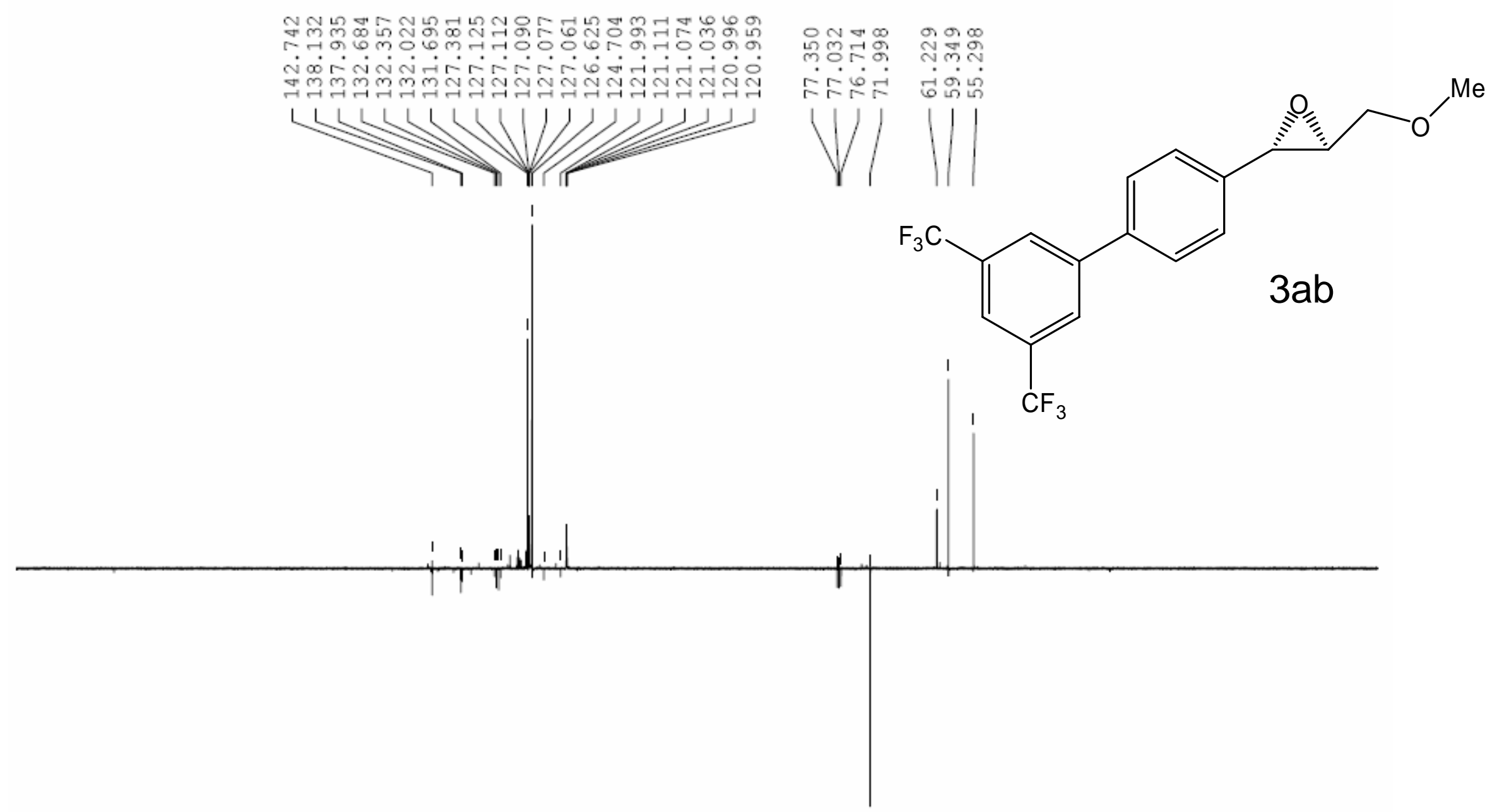

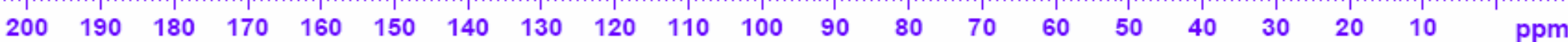




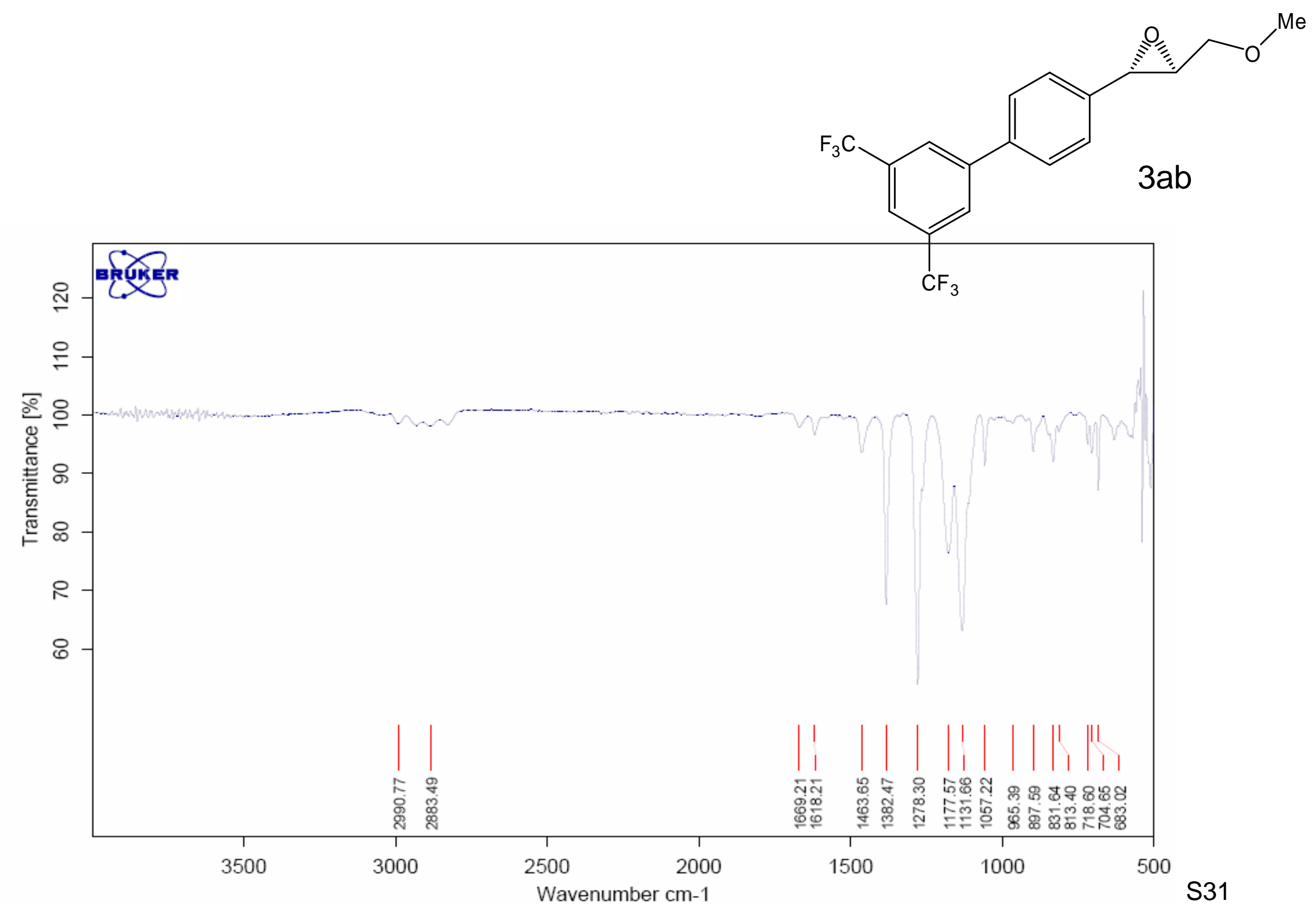




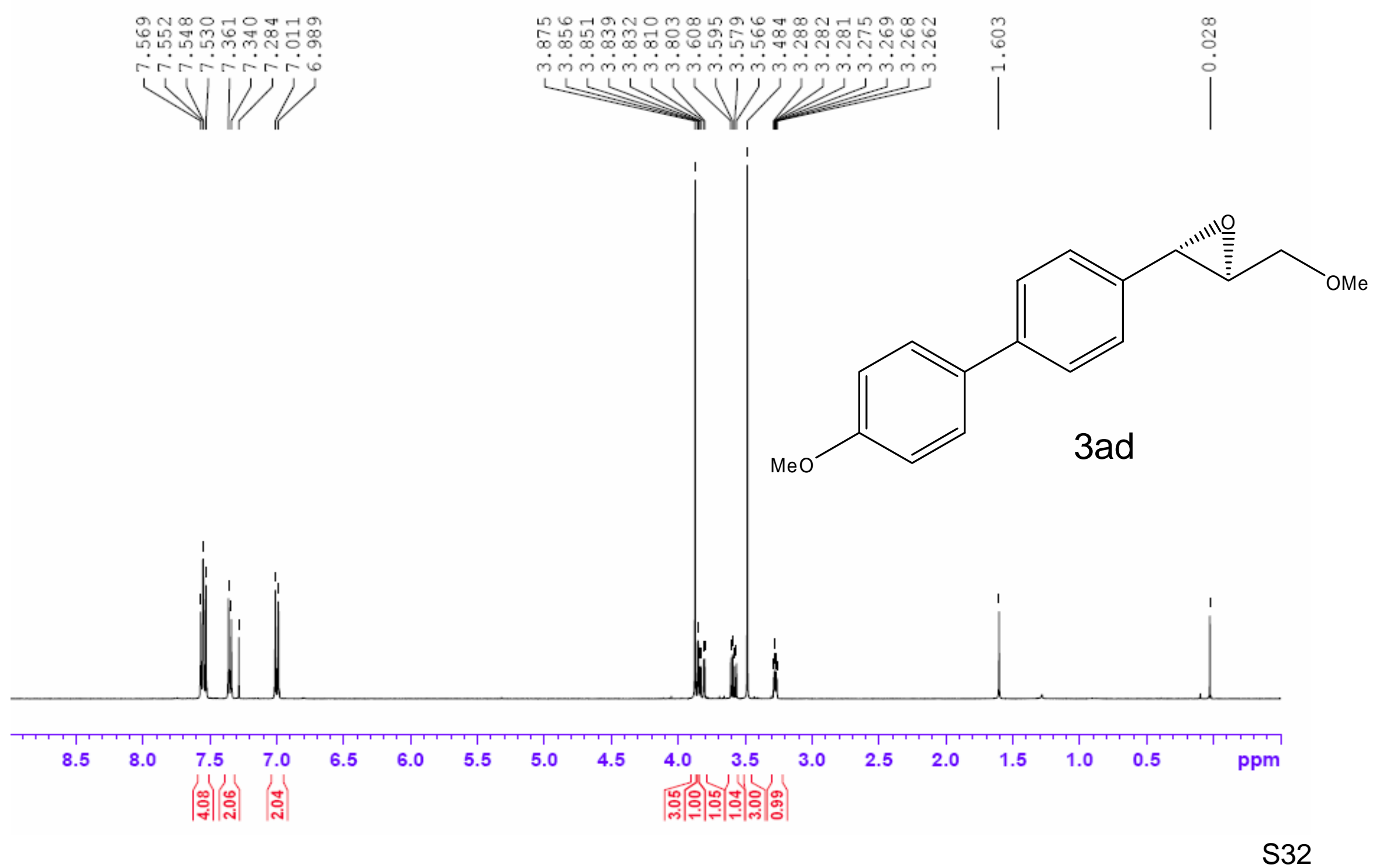




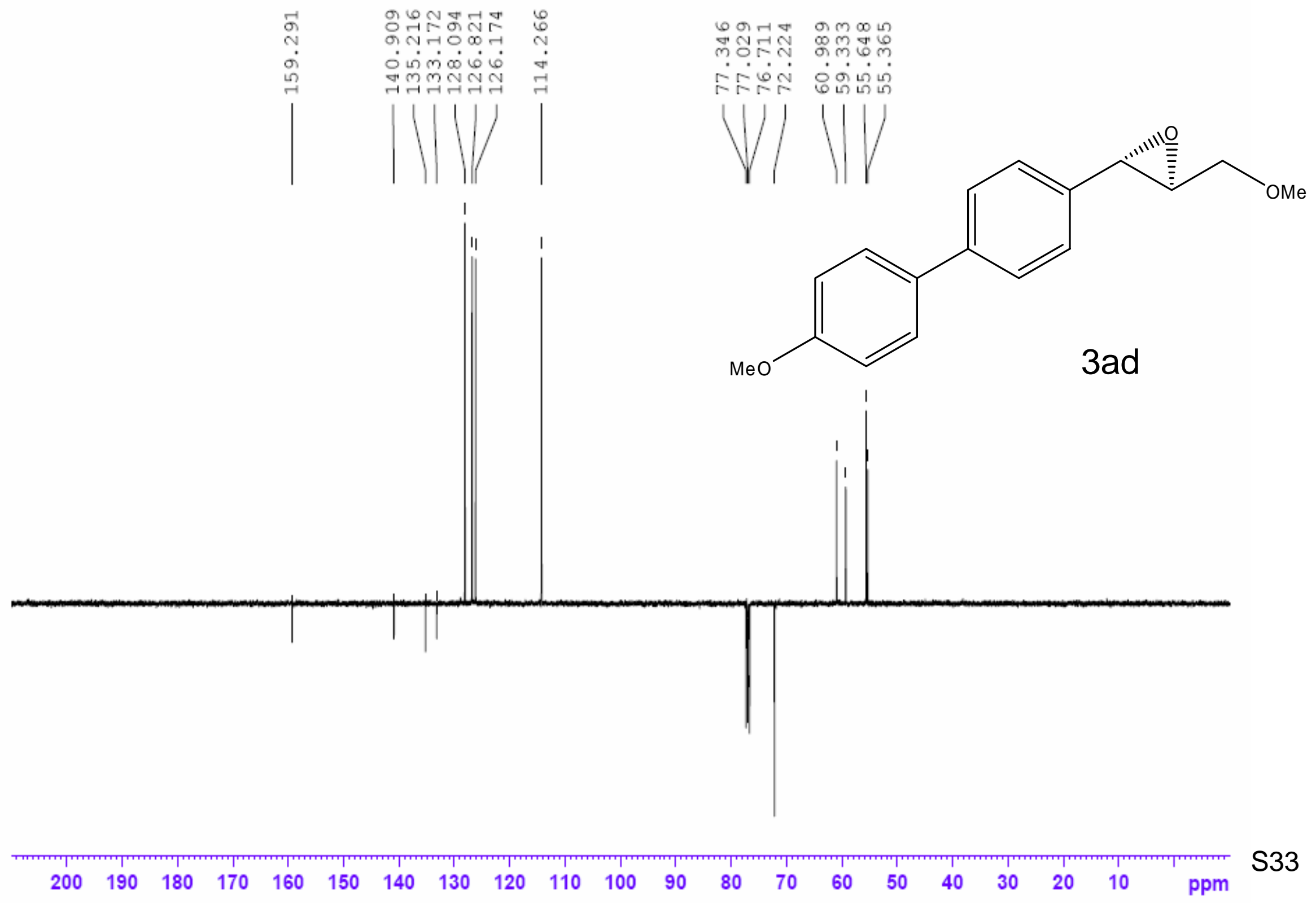




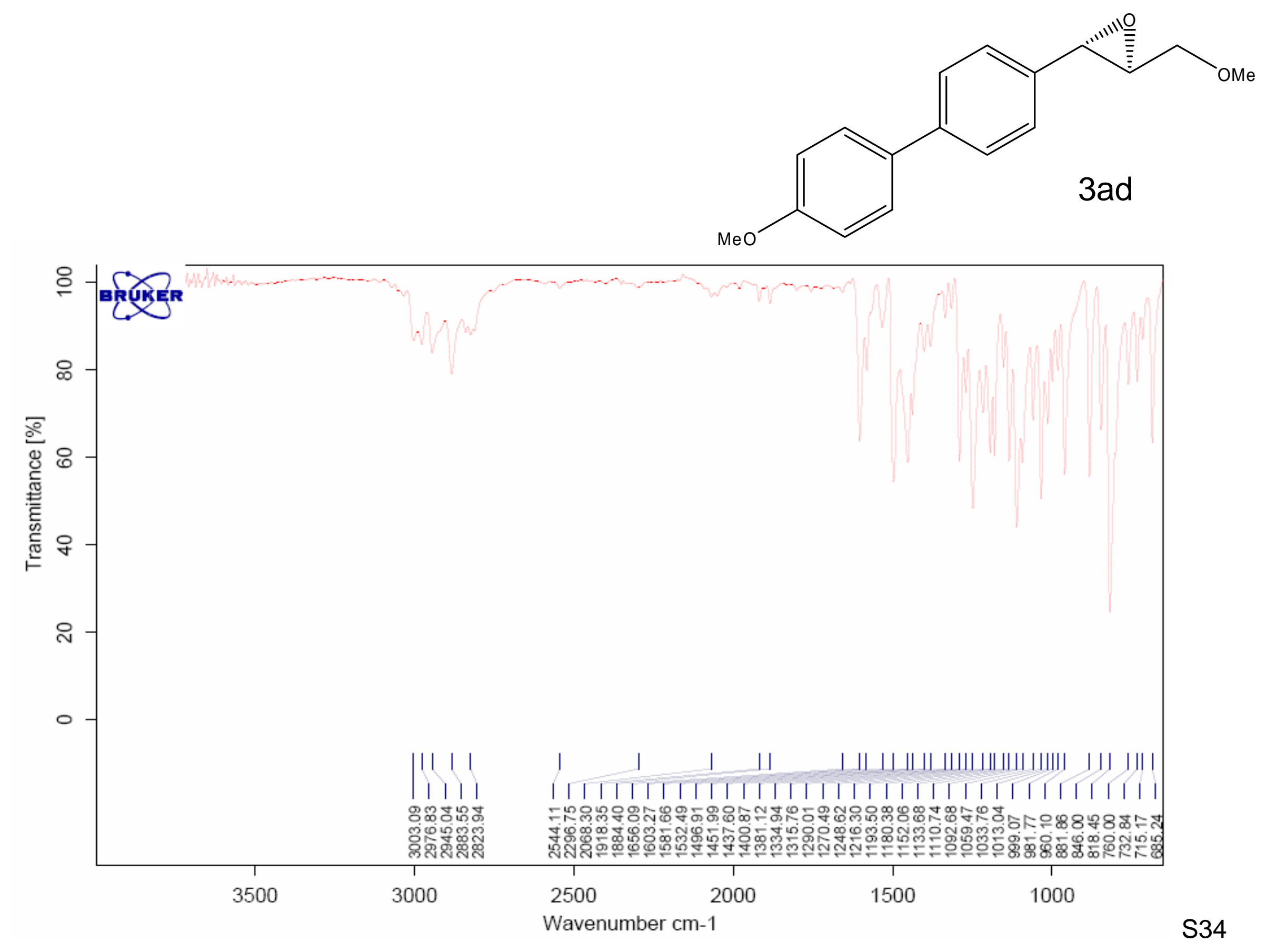




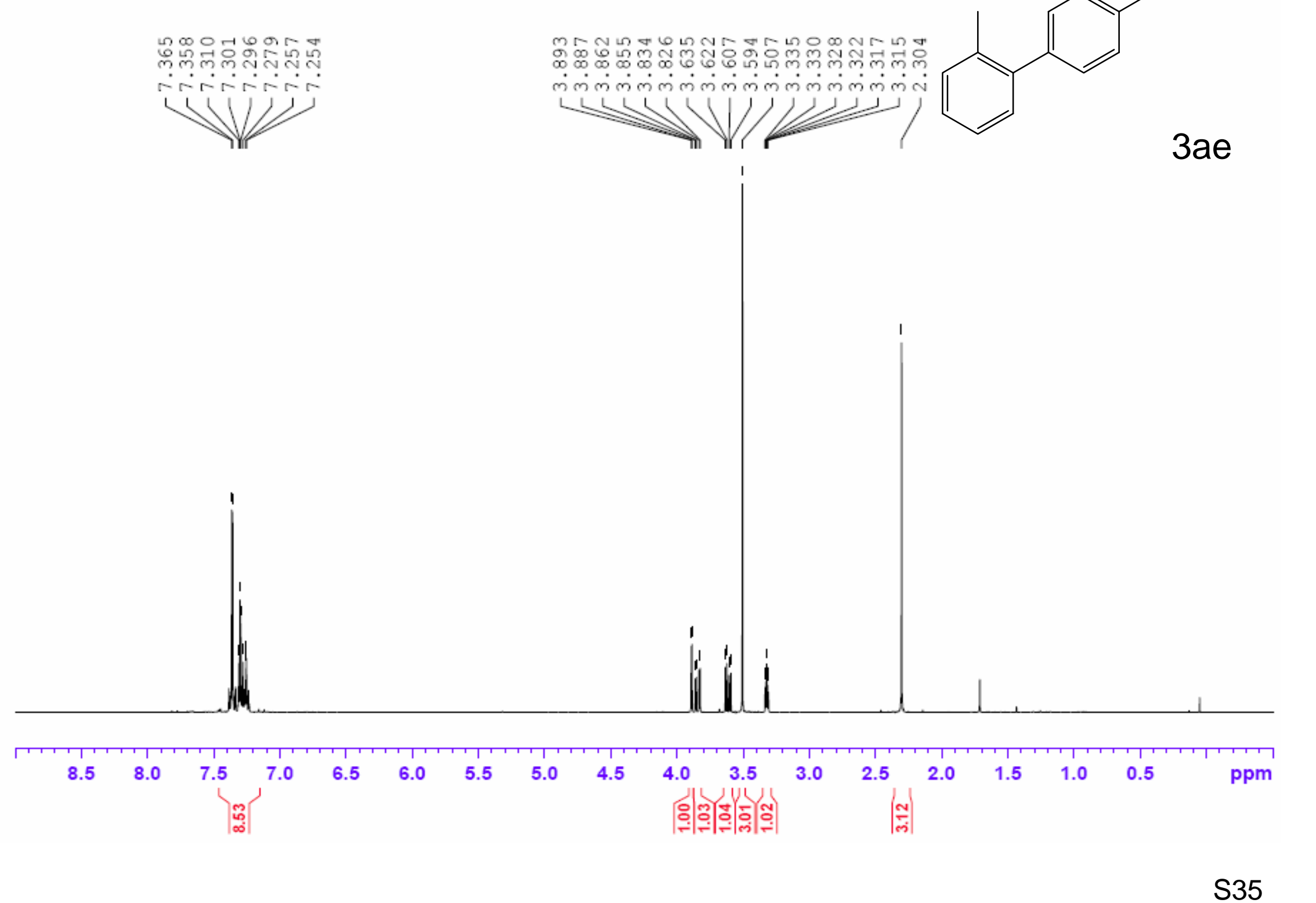




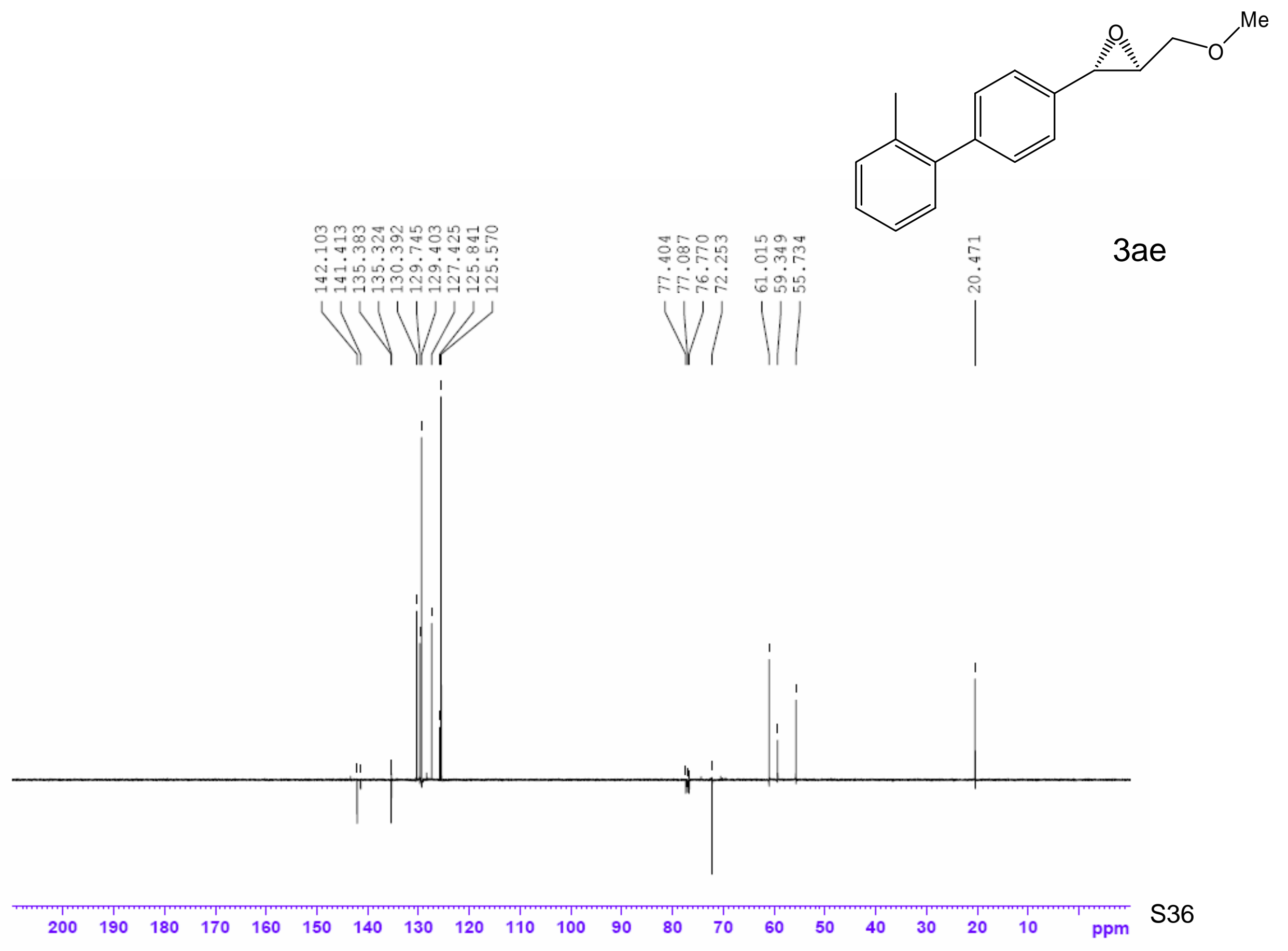




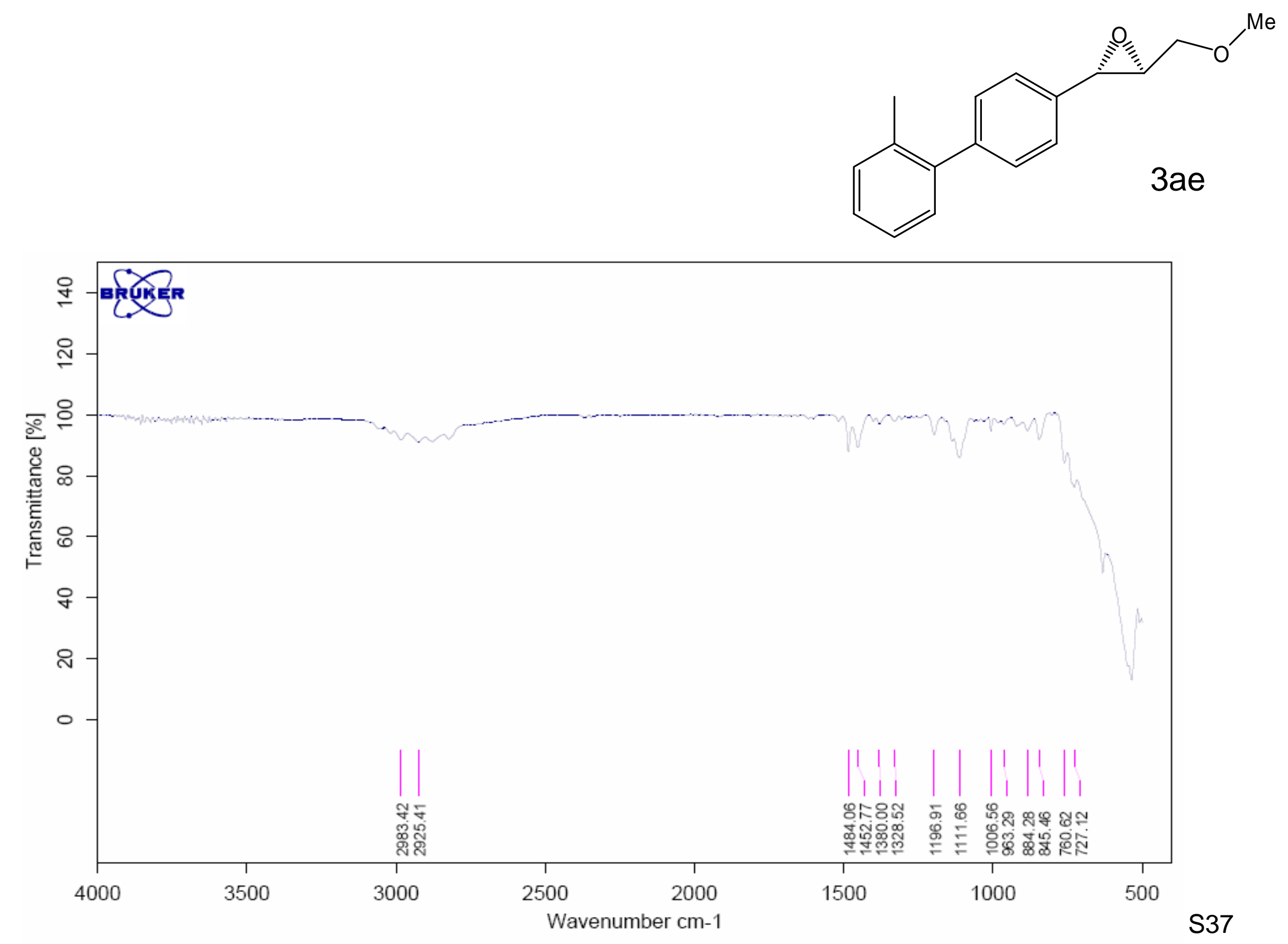




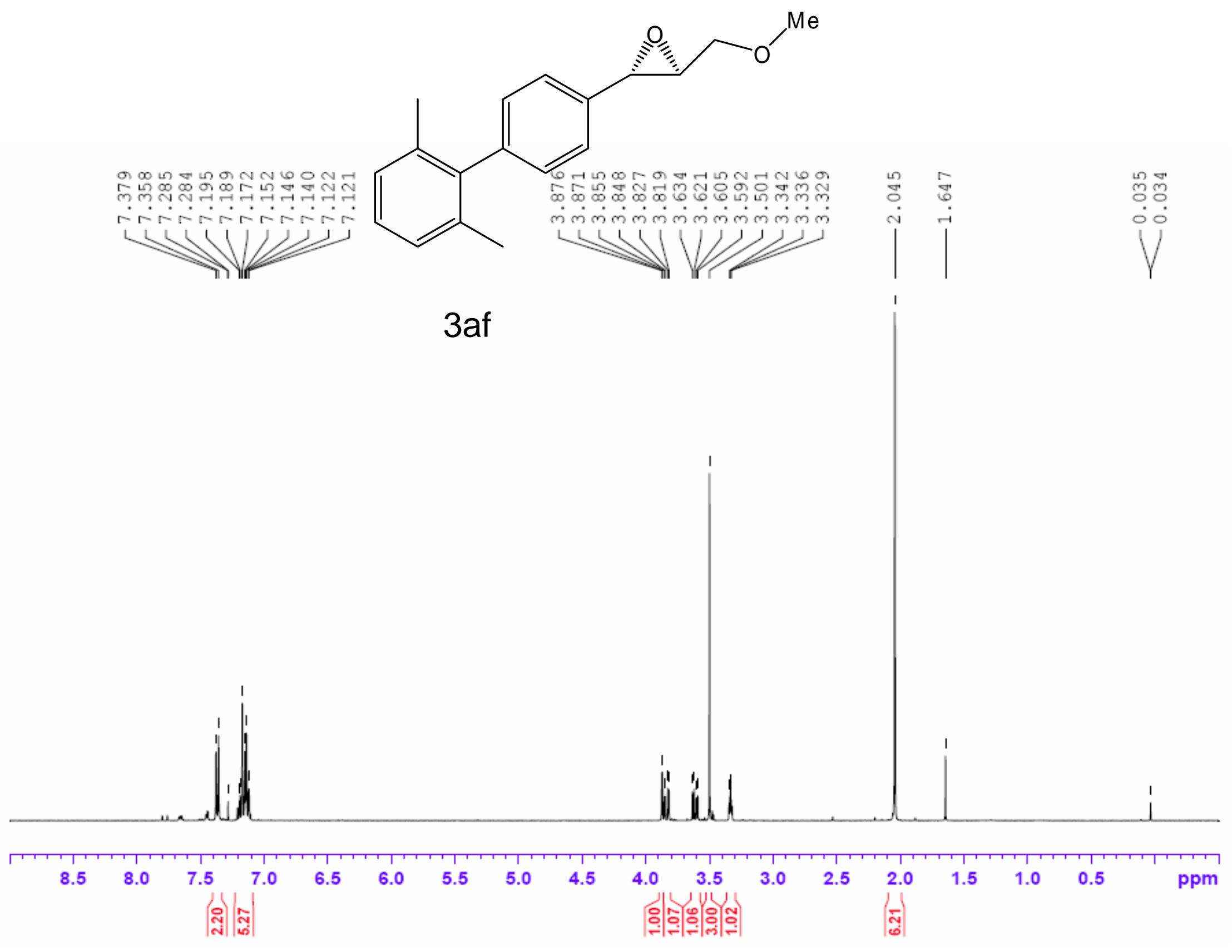



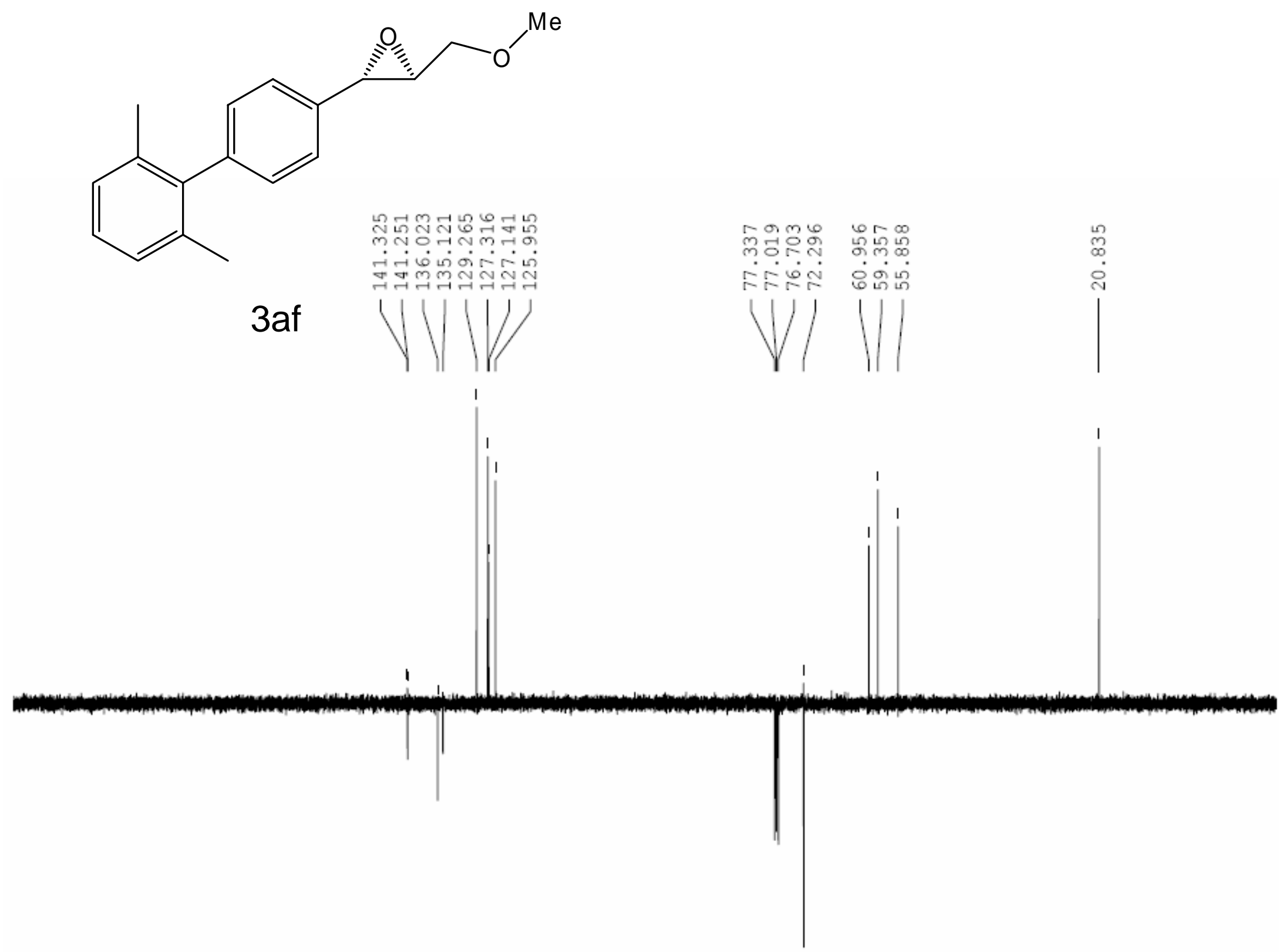

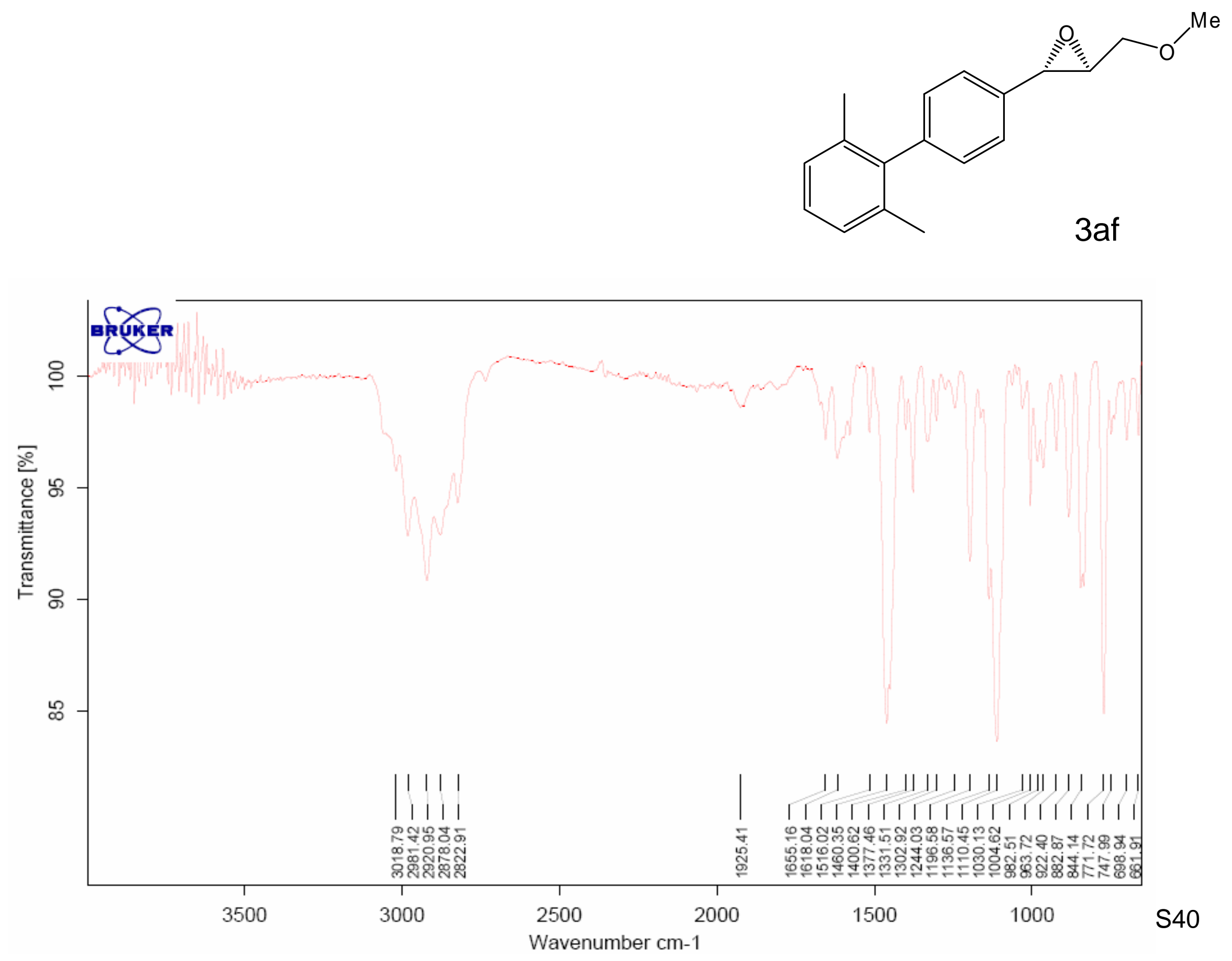


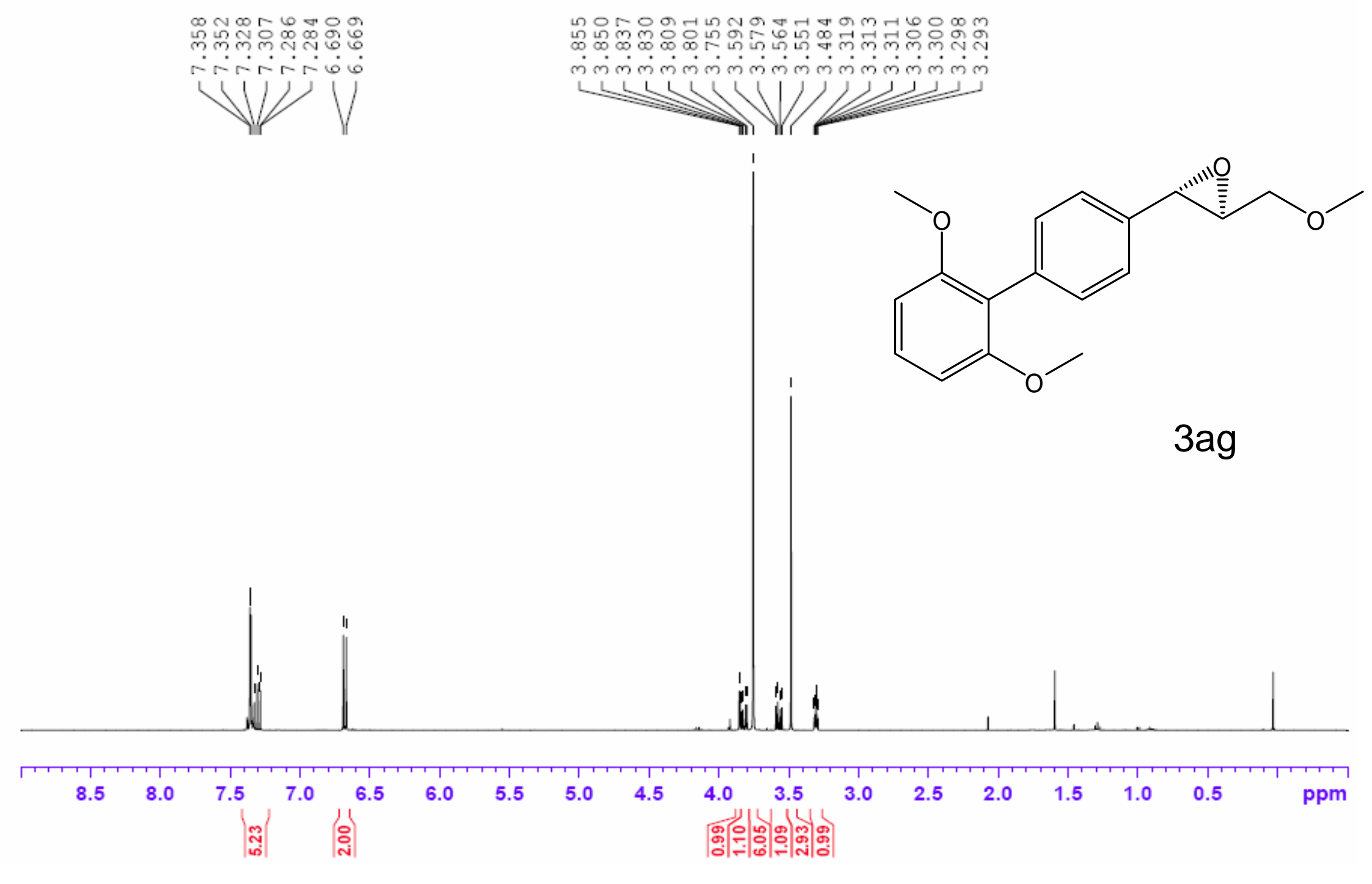




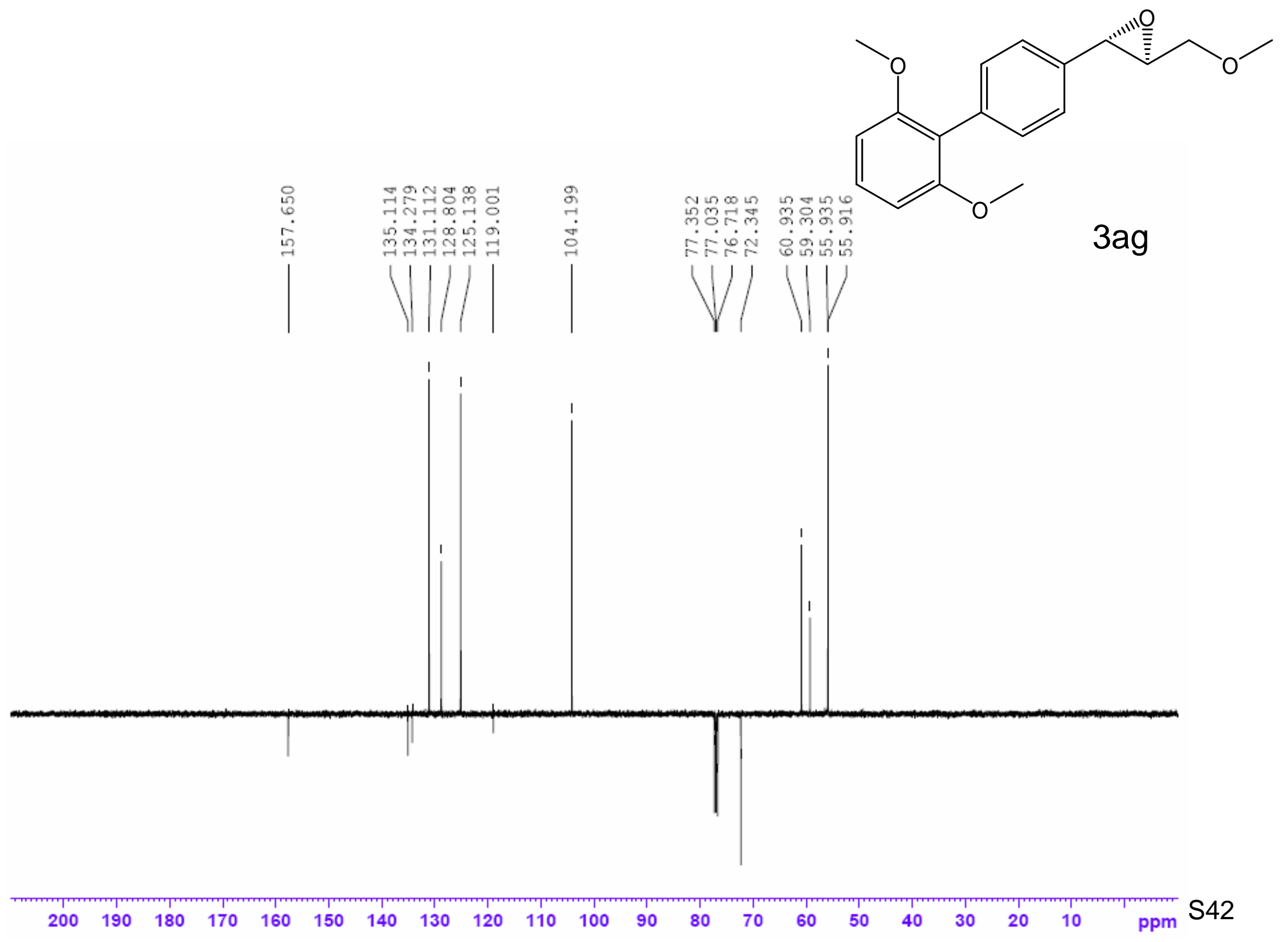



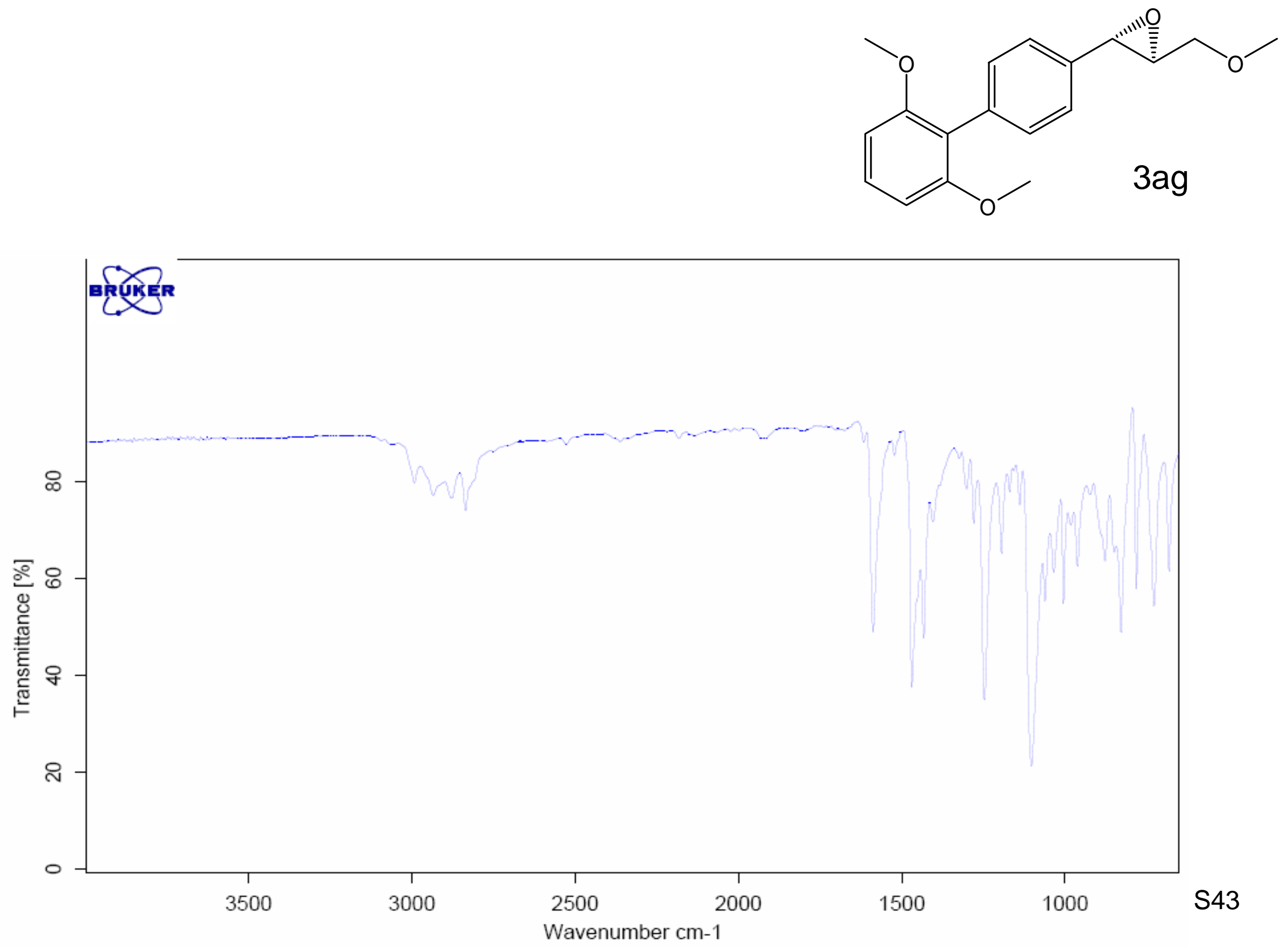


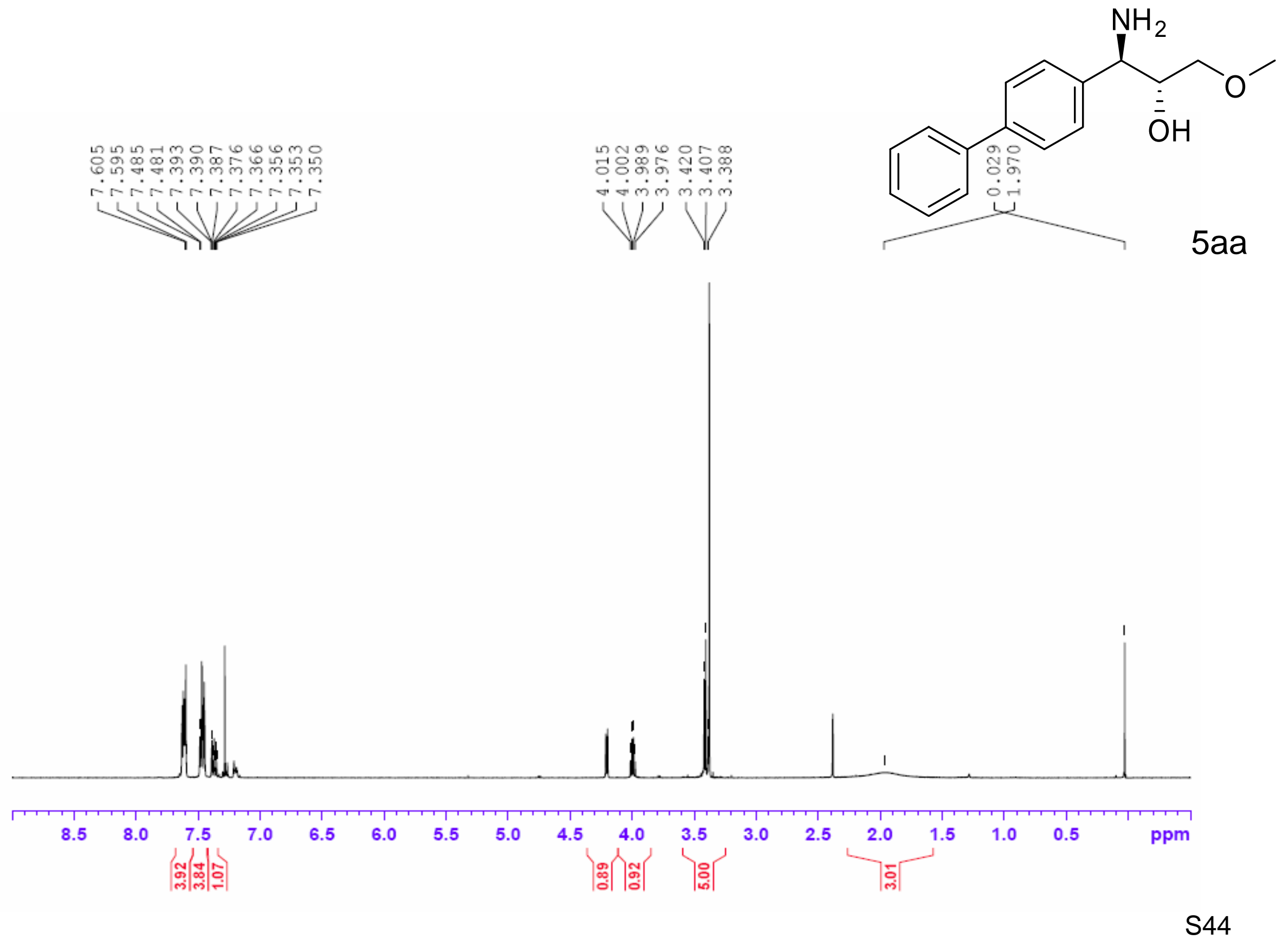




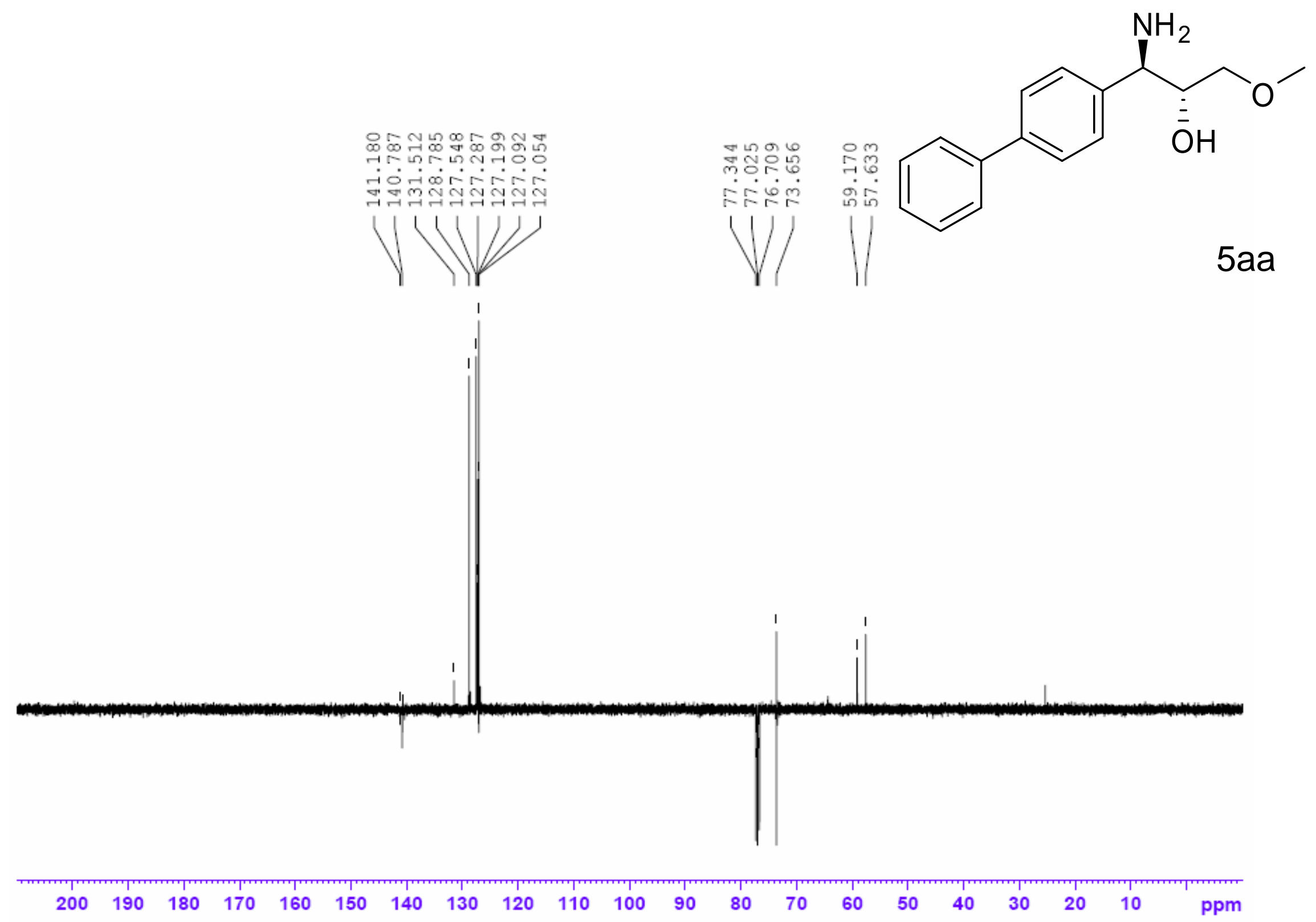




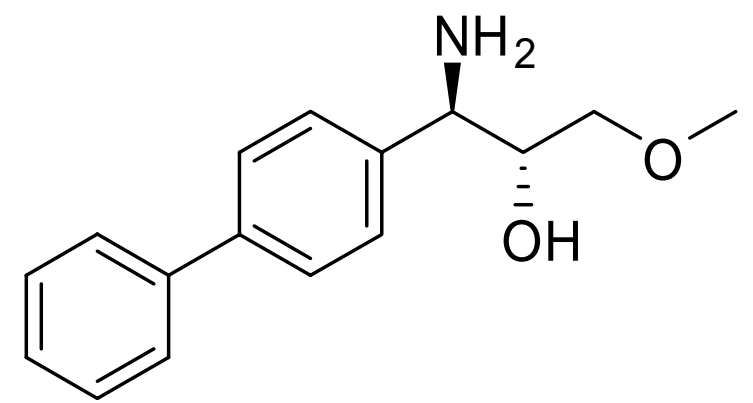

$5 a a$

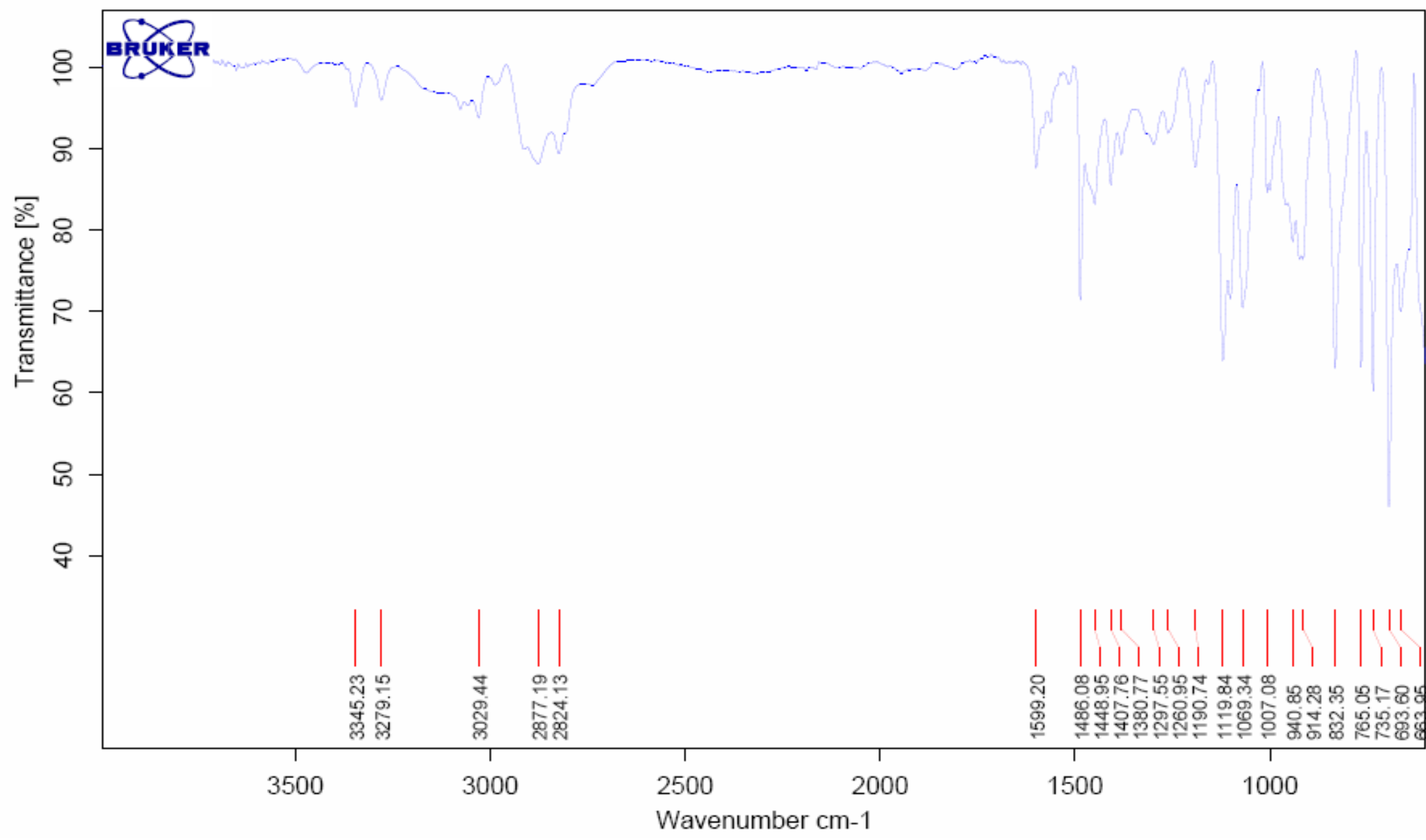



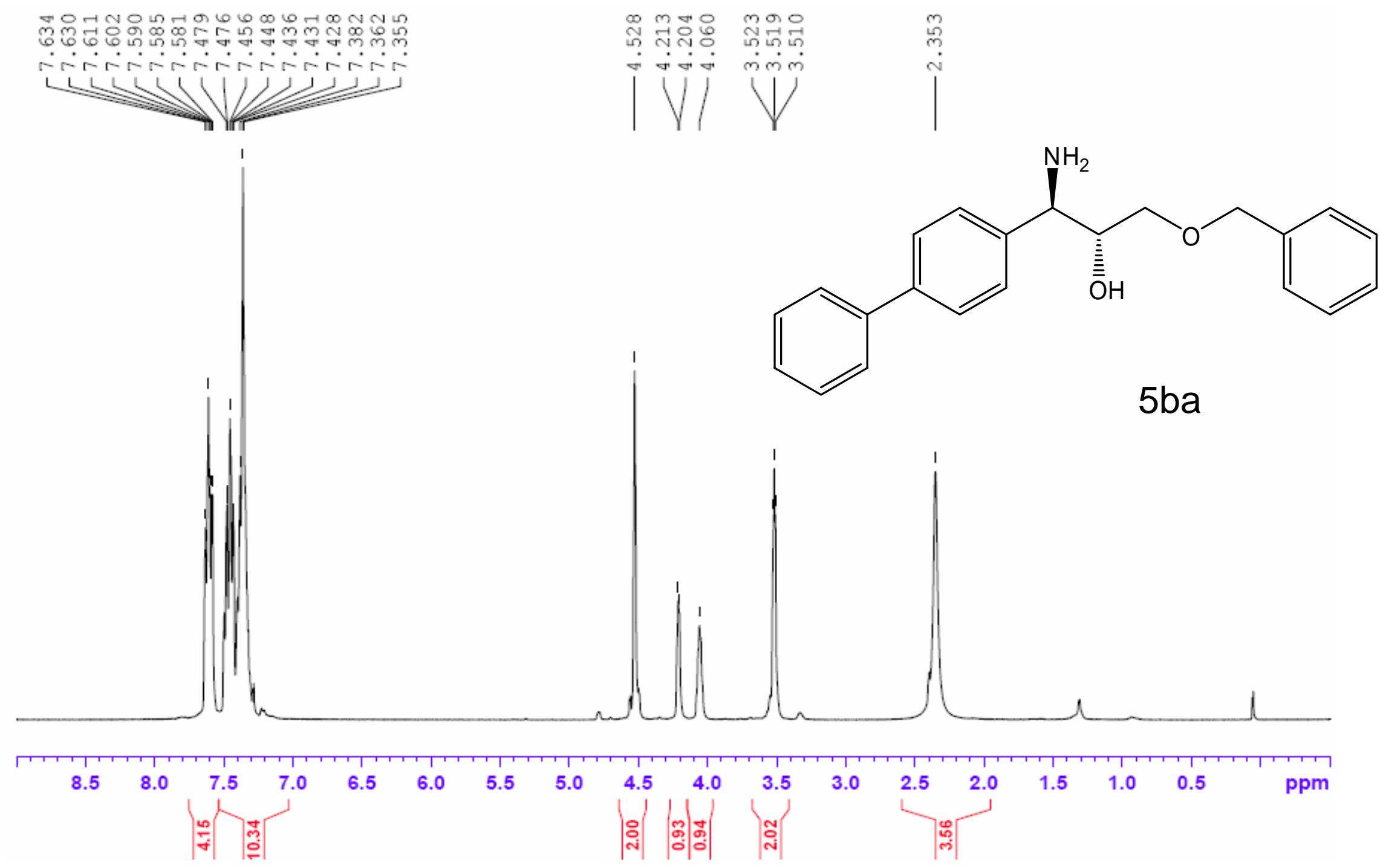


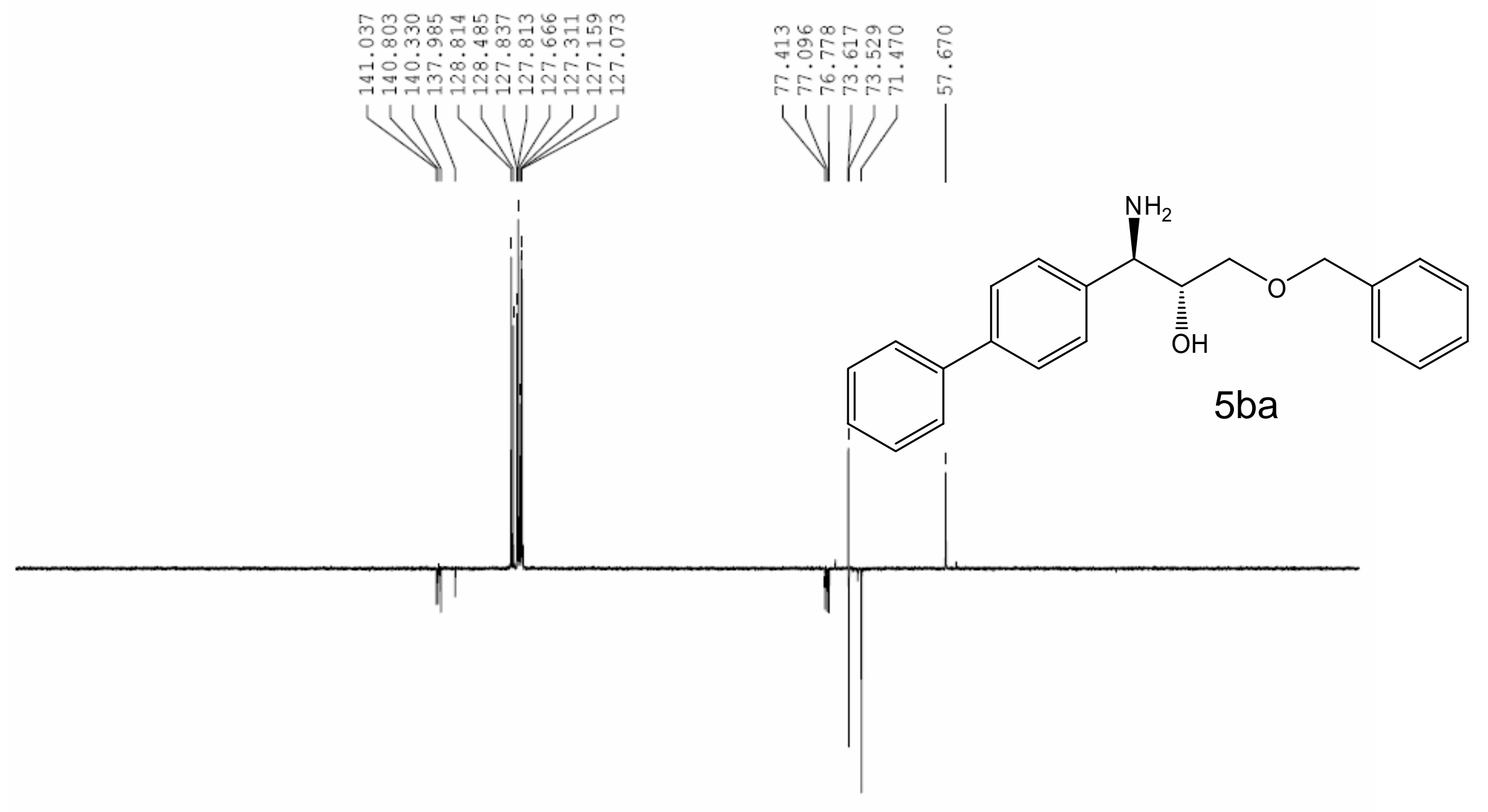

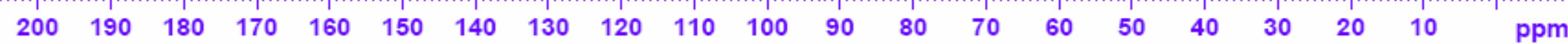



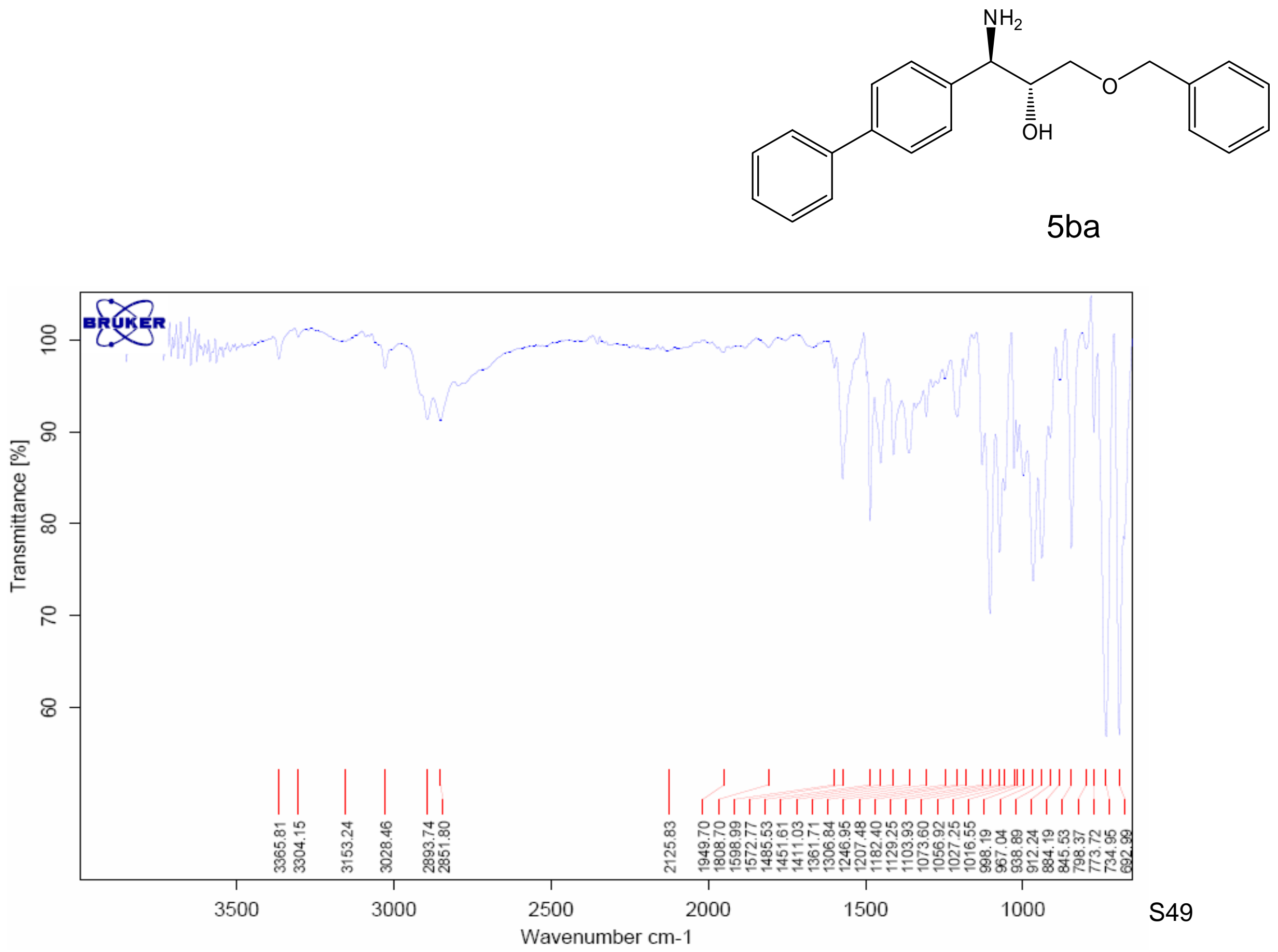


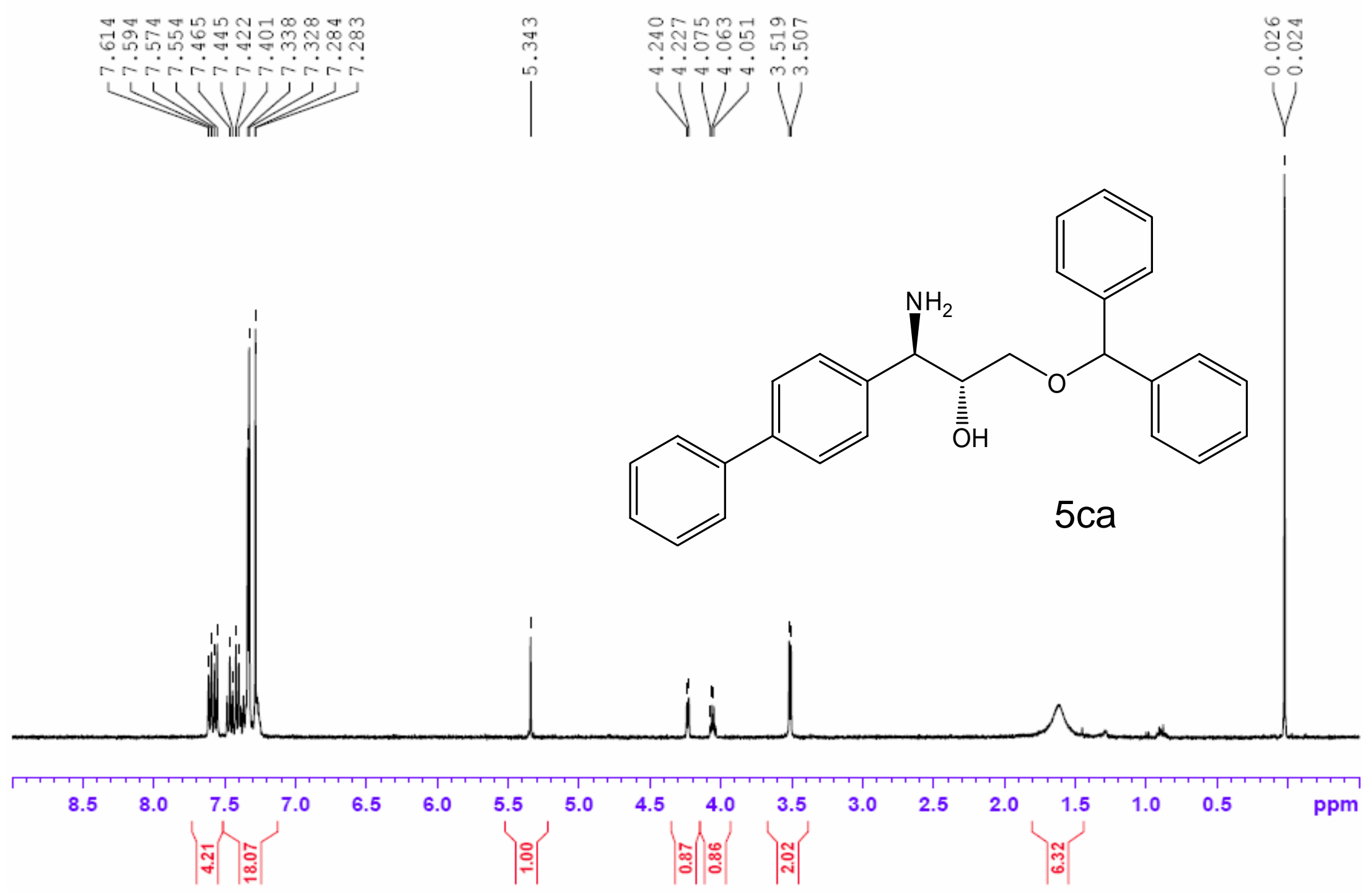




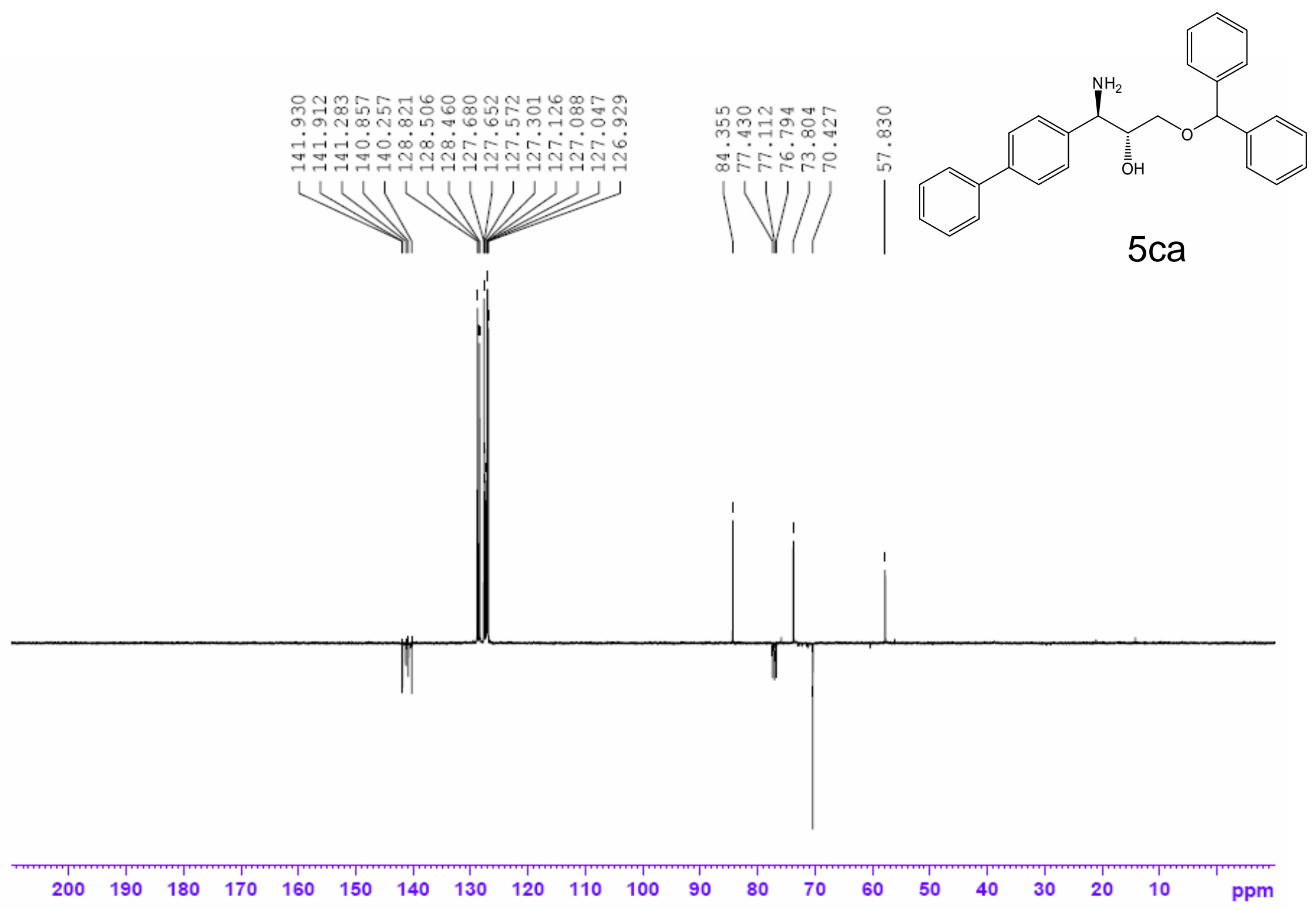




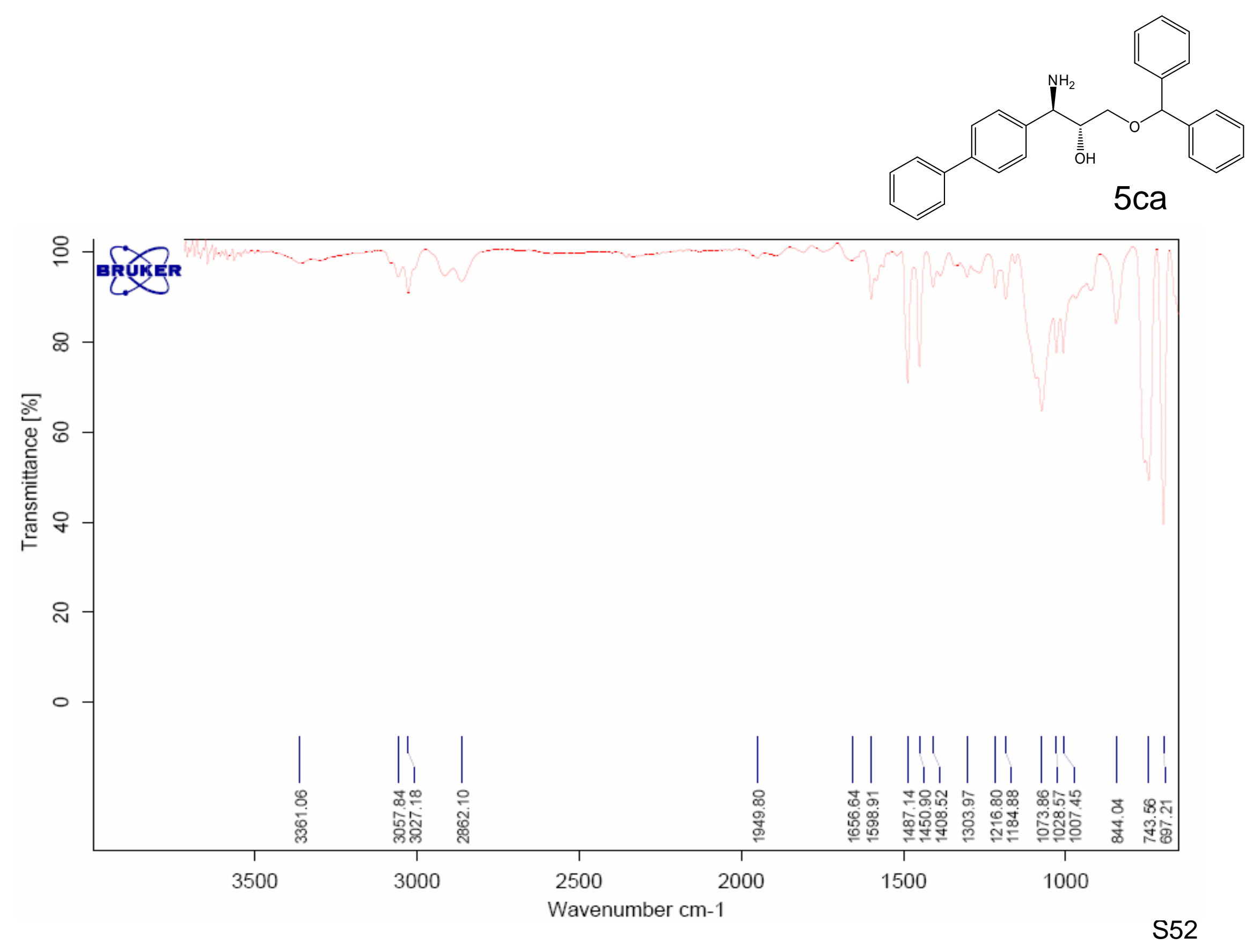



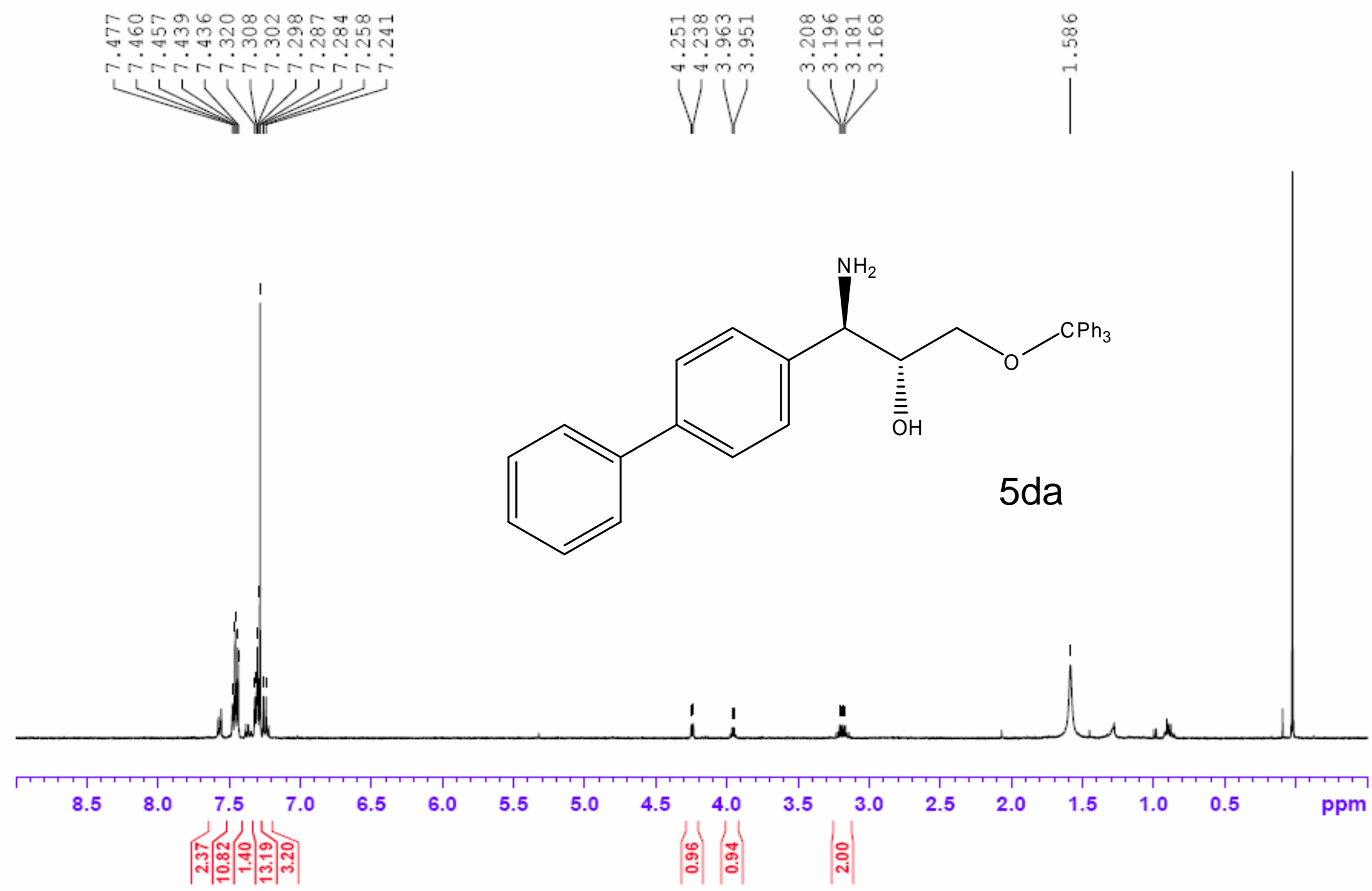


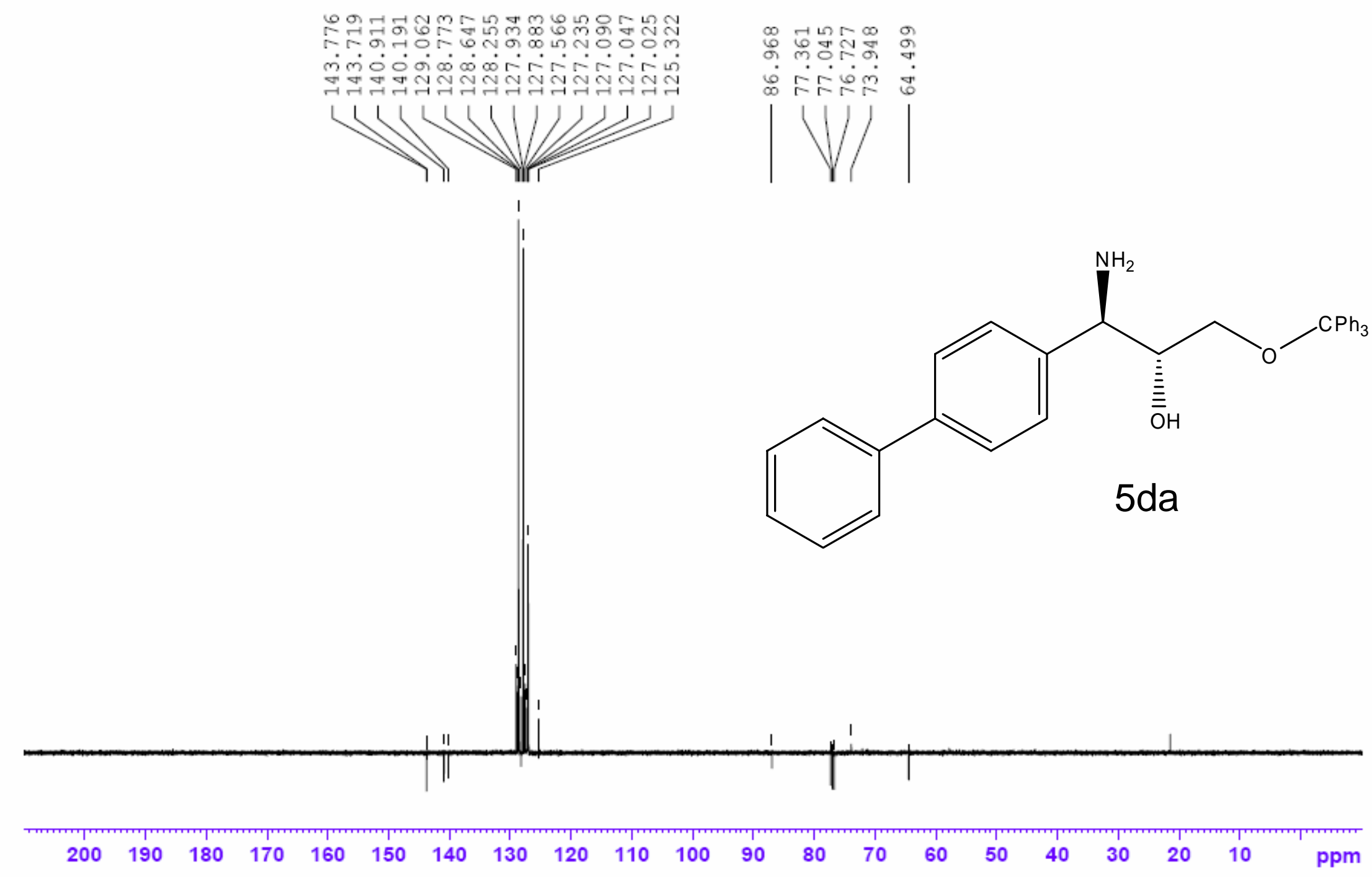




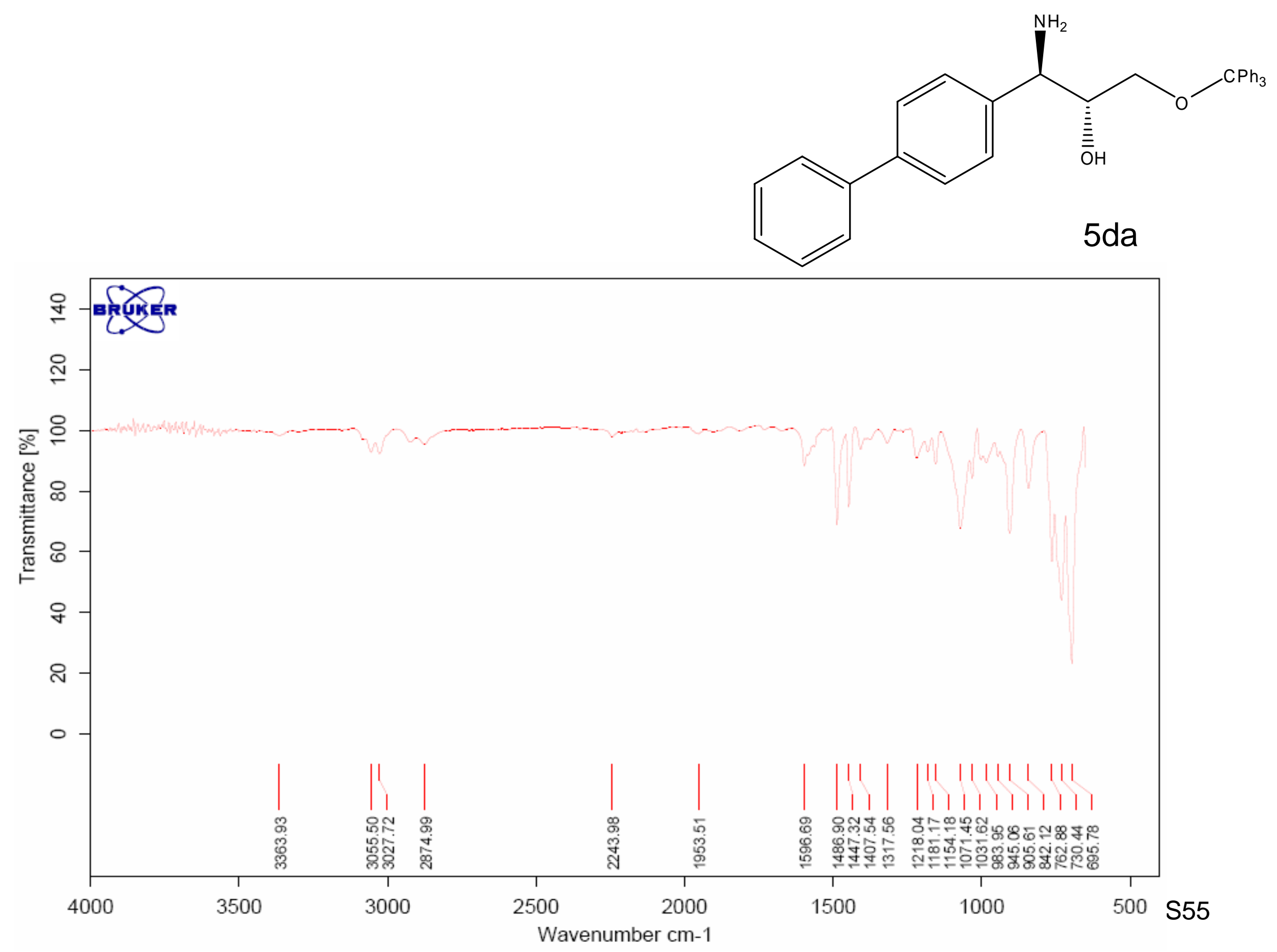




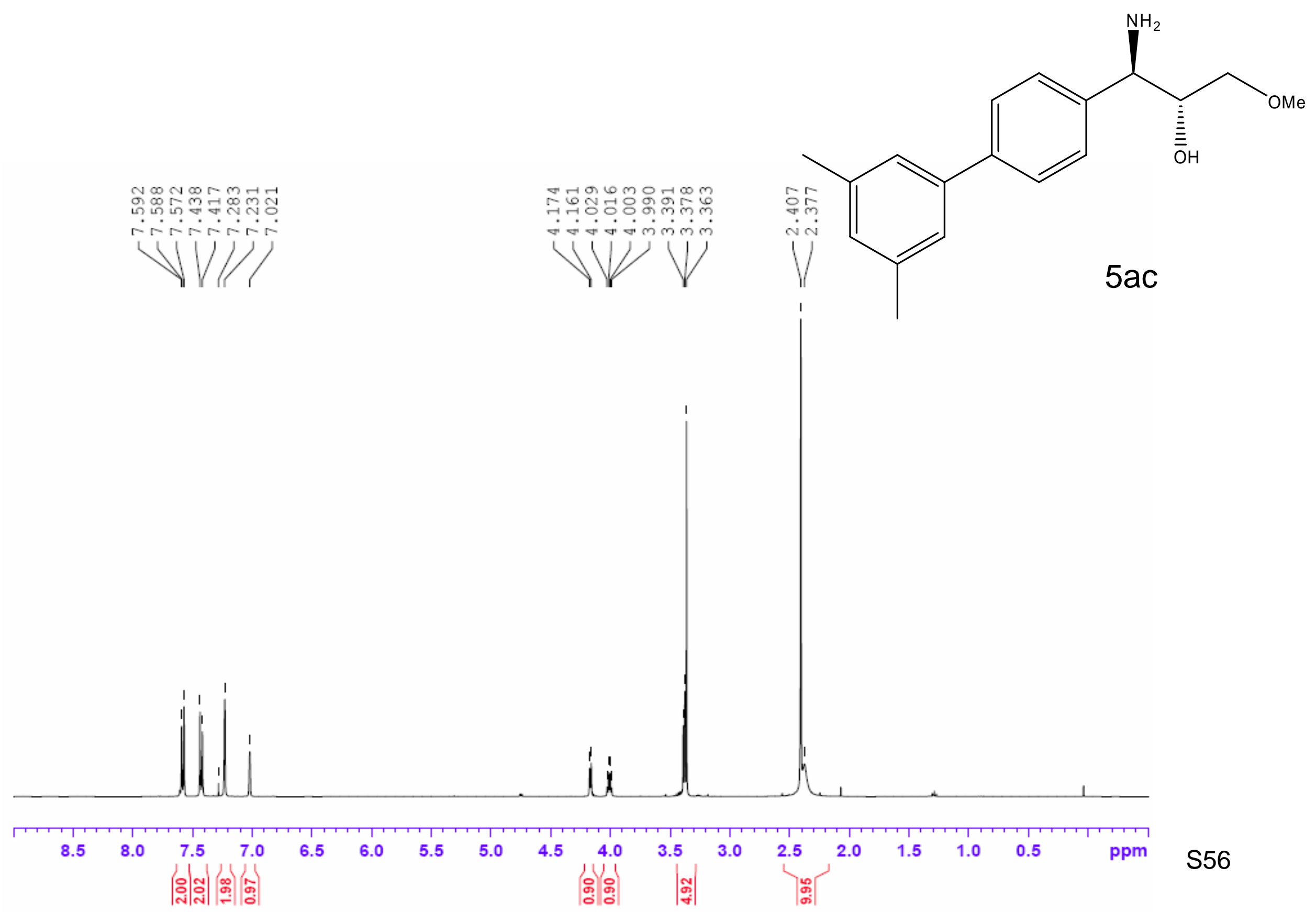




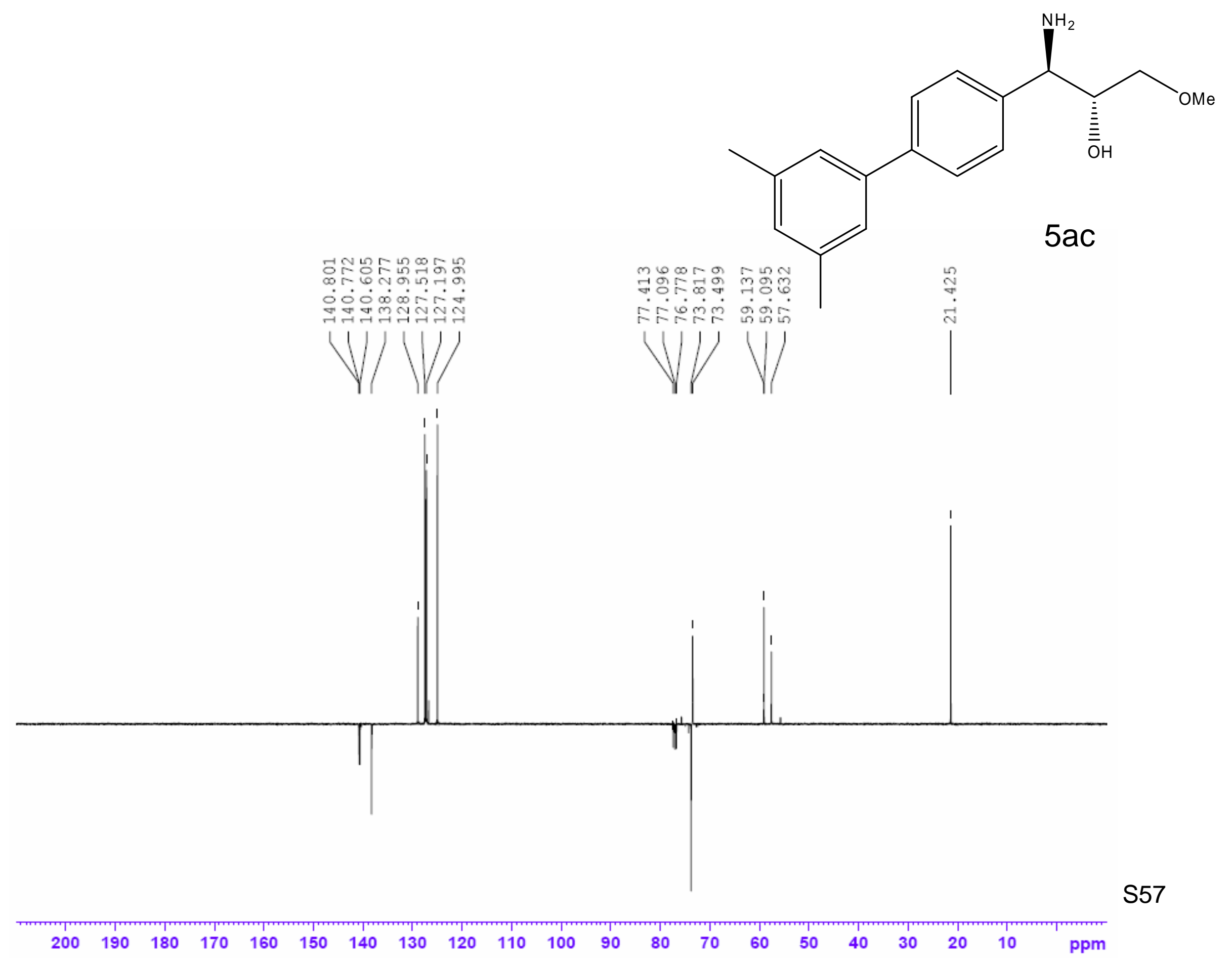




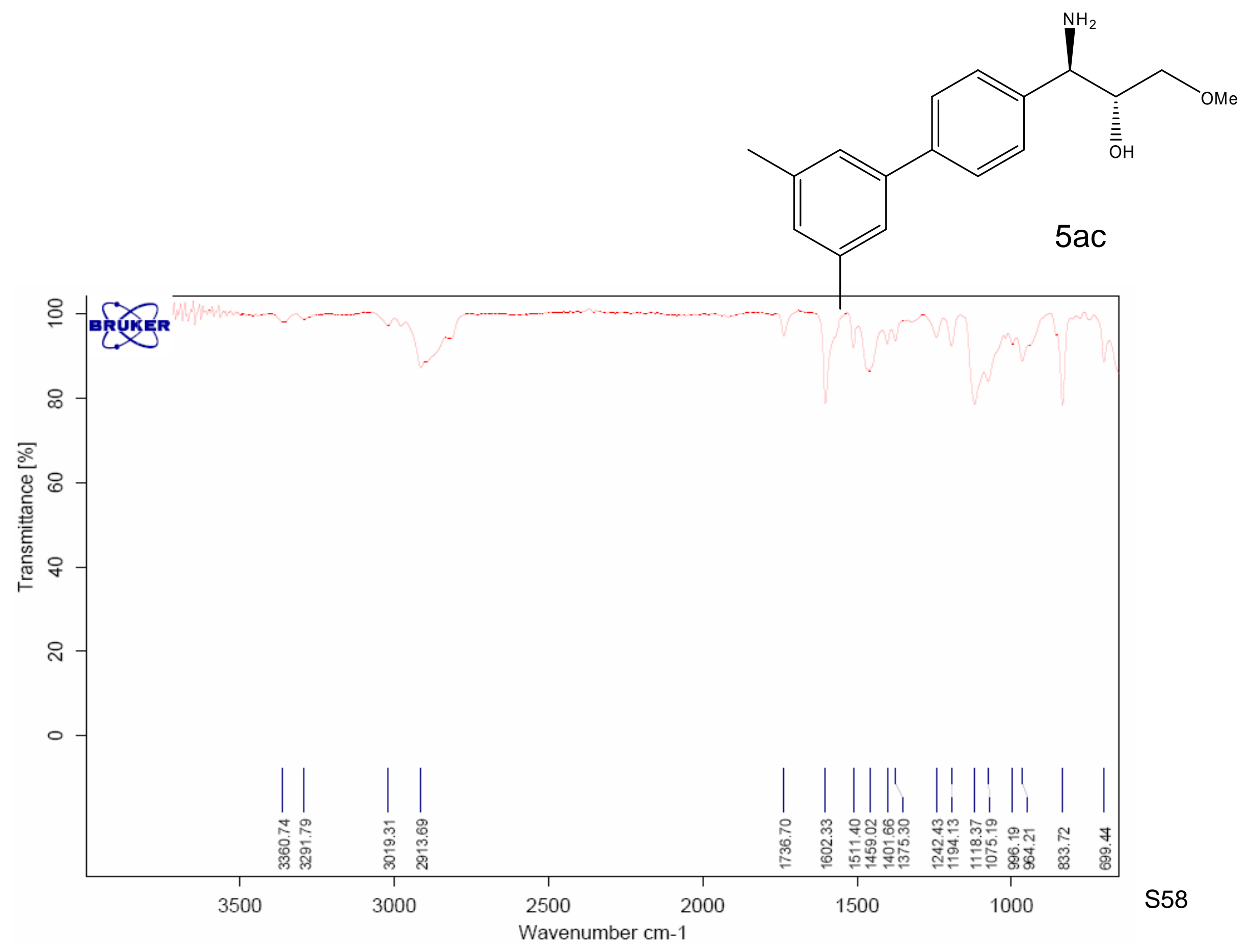




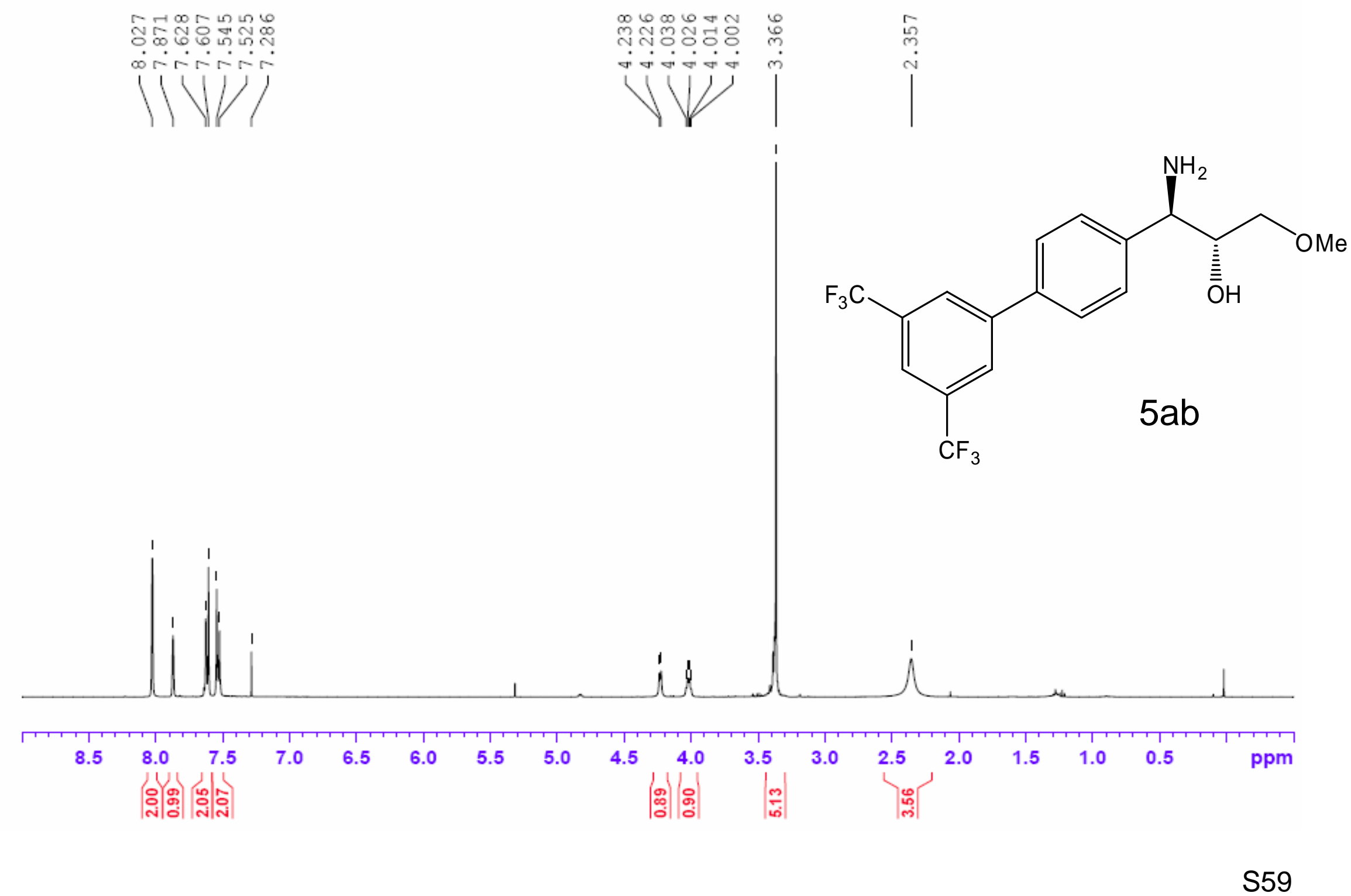




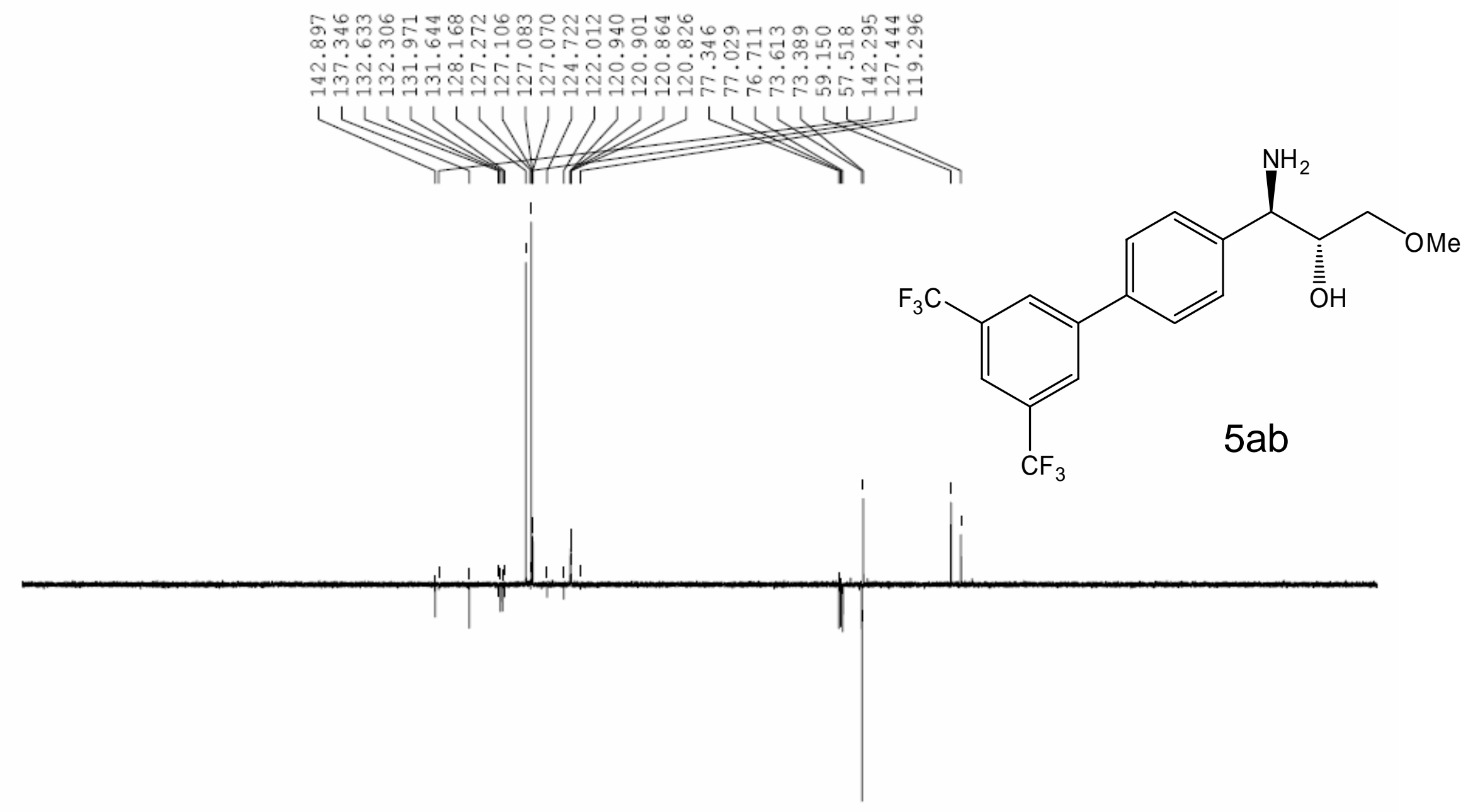

$\begin{array}{lllllllllllllllllllllll}200 & 190 & 180 & 170 & 160 & 150 & 140 & 130 & 120 & 110 & 100 & 90 & 80 & 70 & 60 & 50 & 40 & 30 & 20 & 10 & \mathrm{ppm}\end{array}$ 

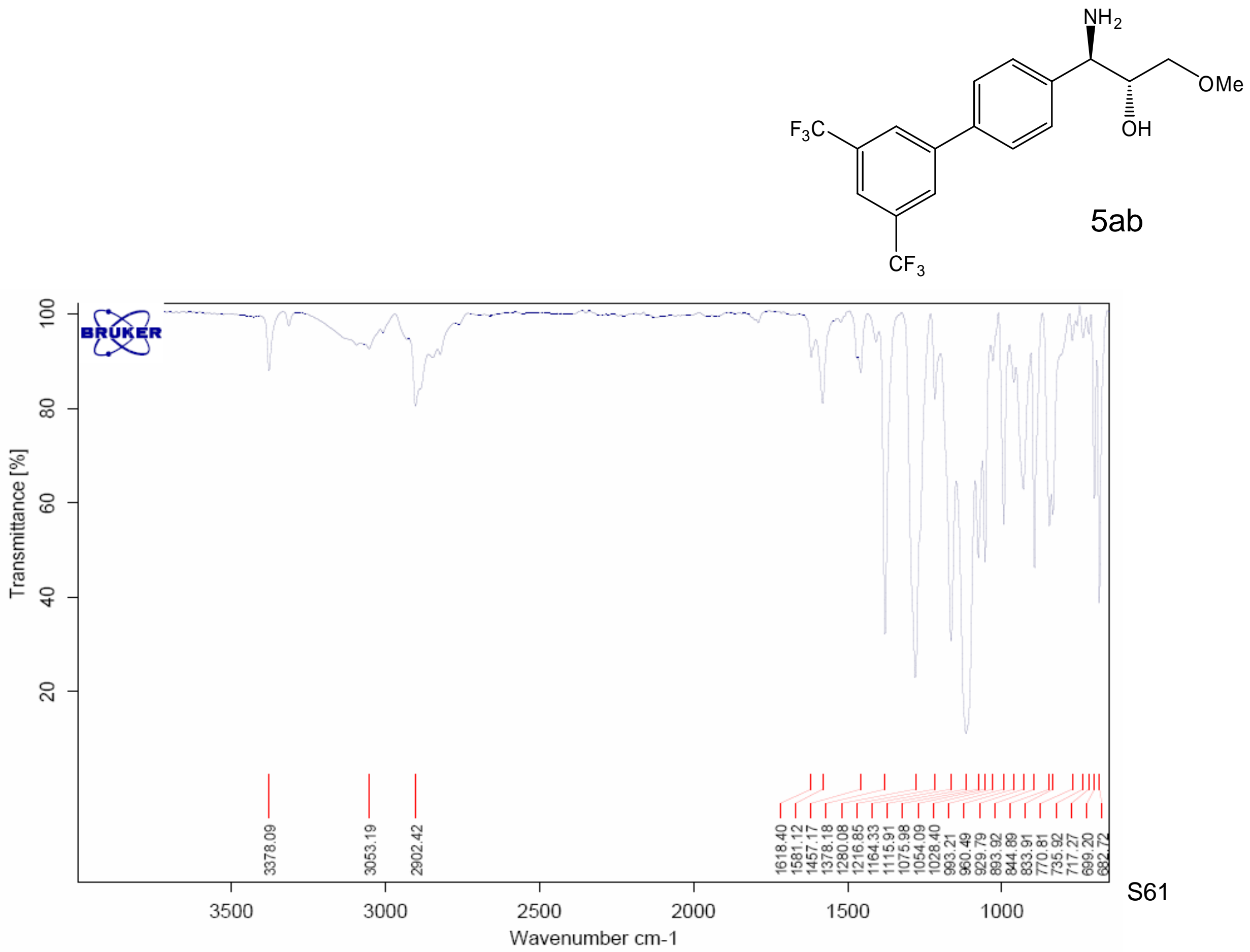


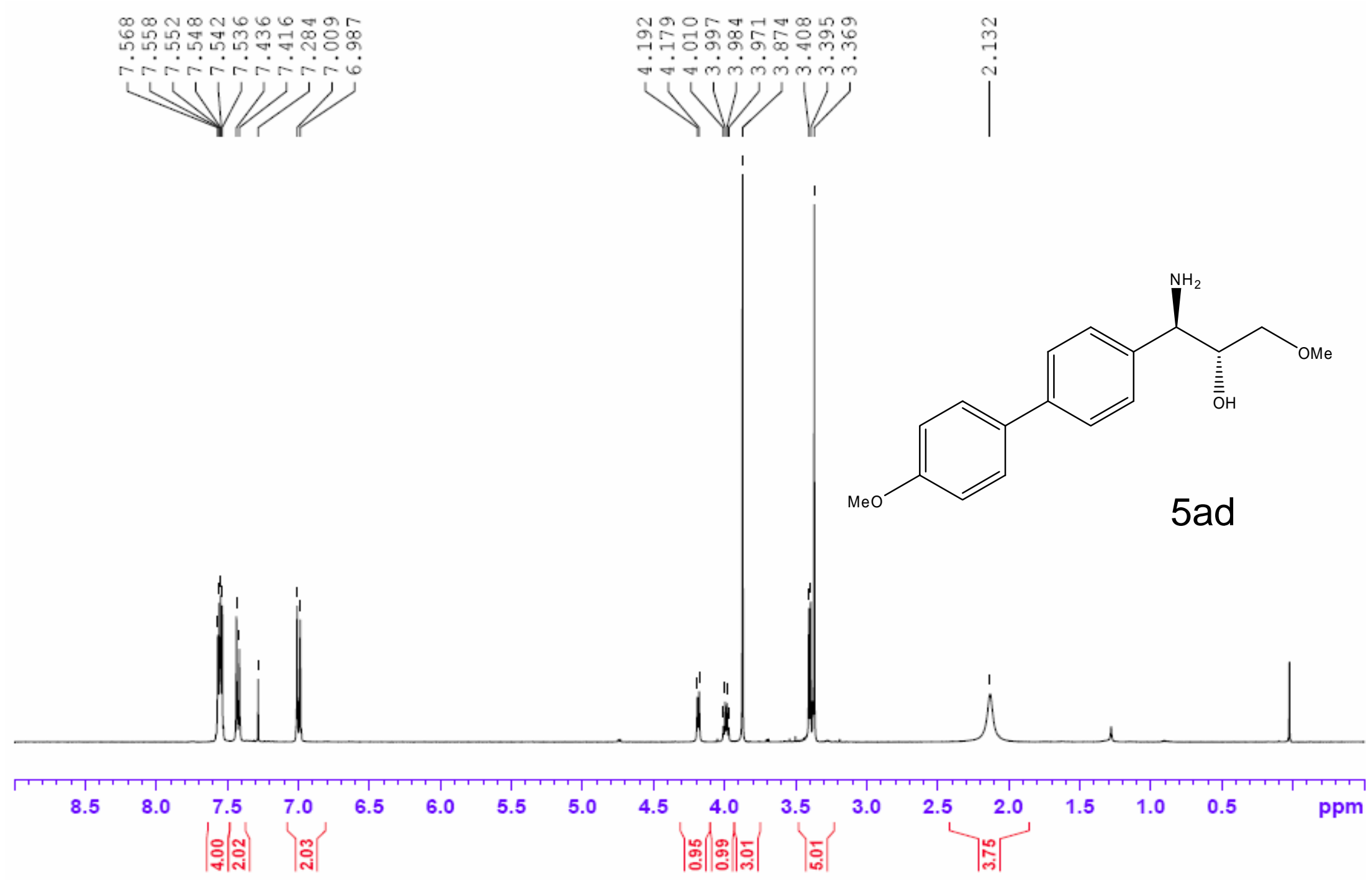




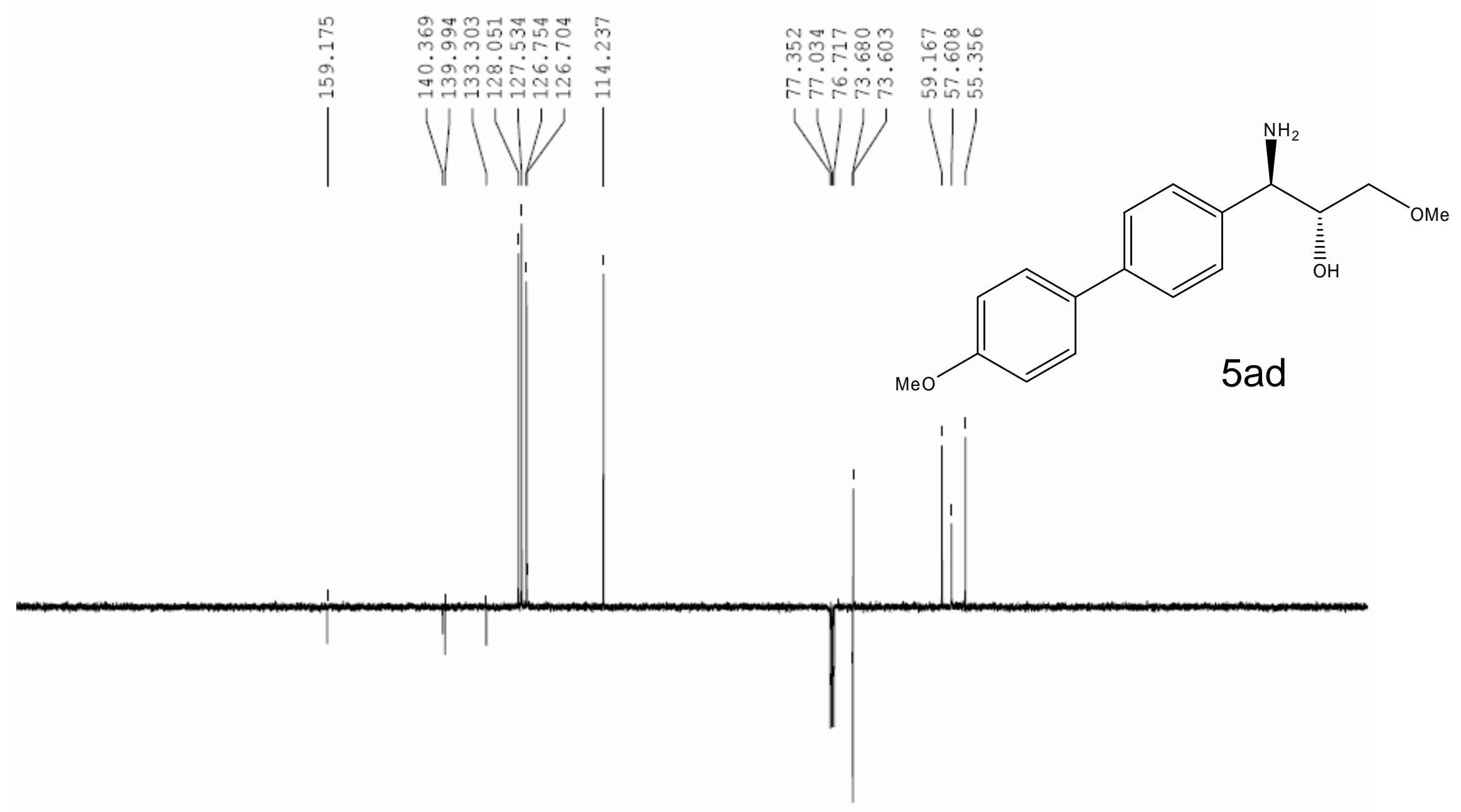

$\begin{array}{lllllllllllllllllllll}200 & 190 & 180 & 170 & 160 & 150 & 140 & 130 & 120 & 110 & 100 & 90 & 80 & 70 & 60 & 50 & 40 & 30 & 20 & 10 & \text { ppm }\end{array}$ 

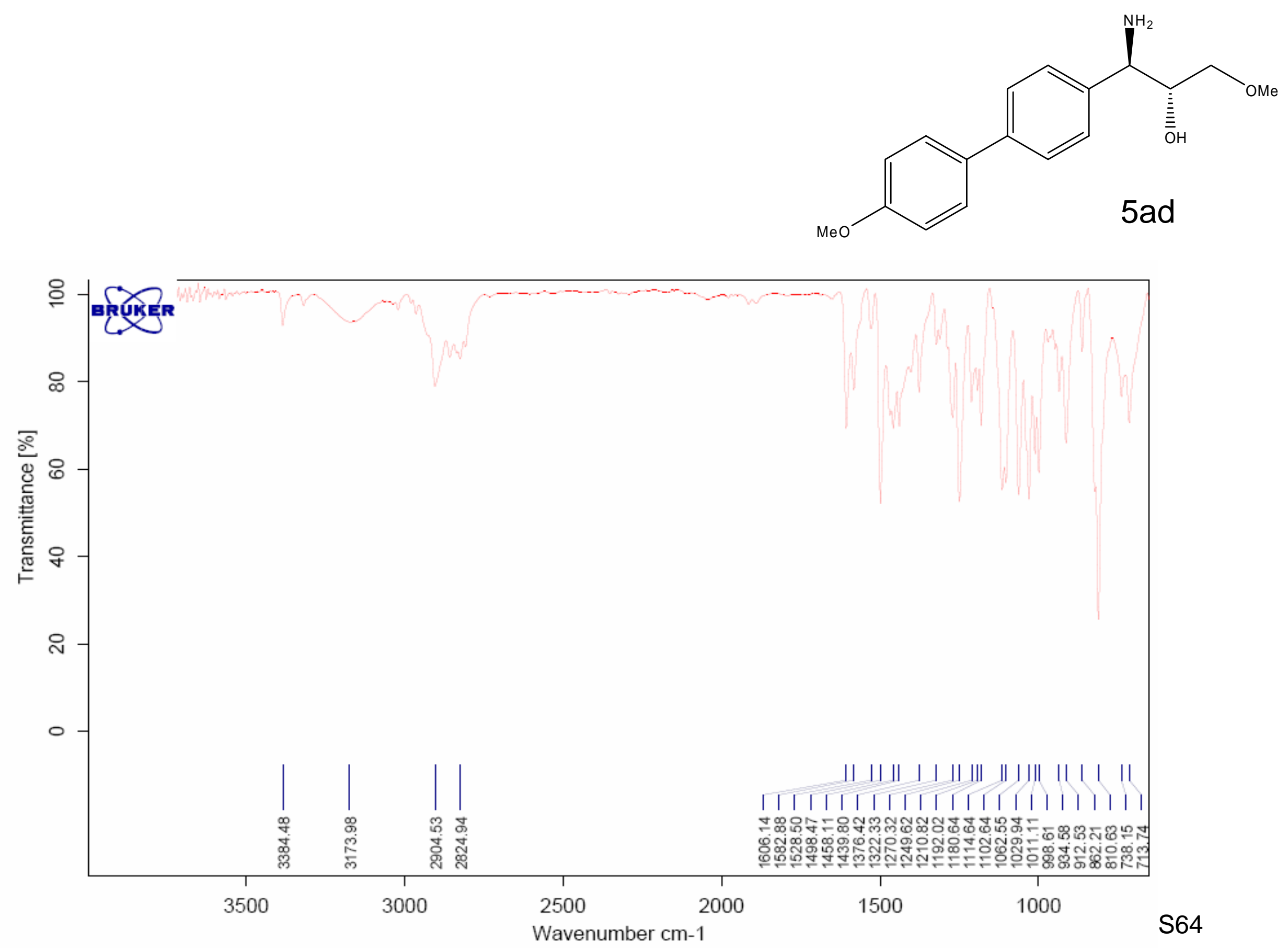


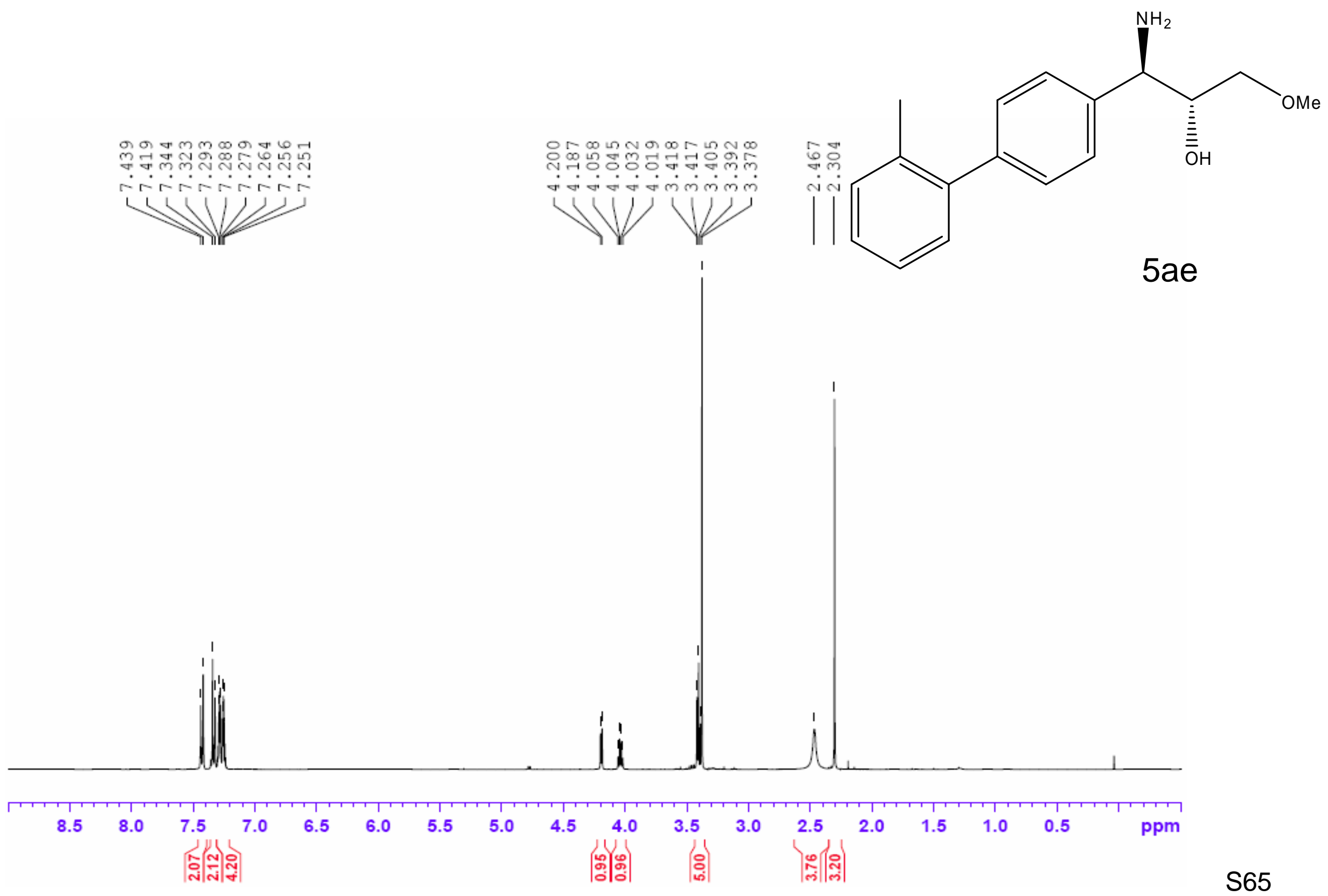




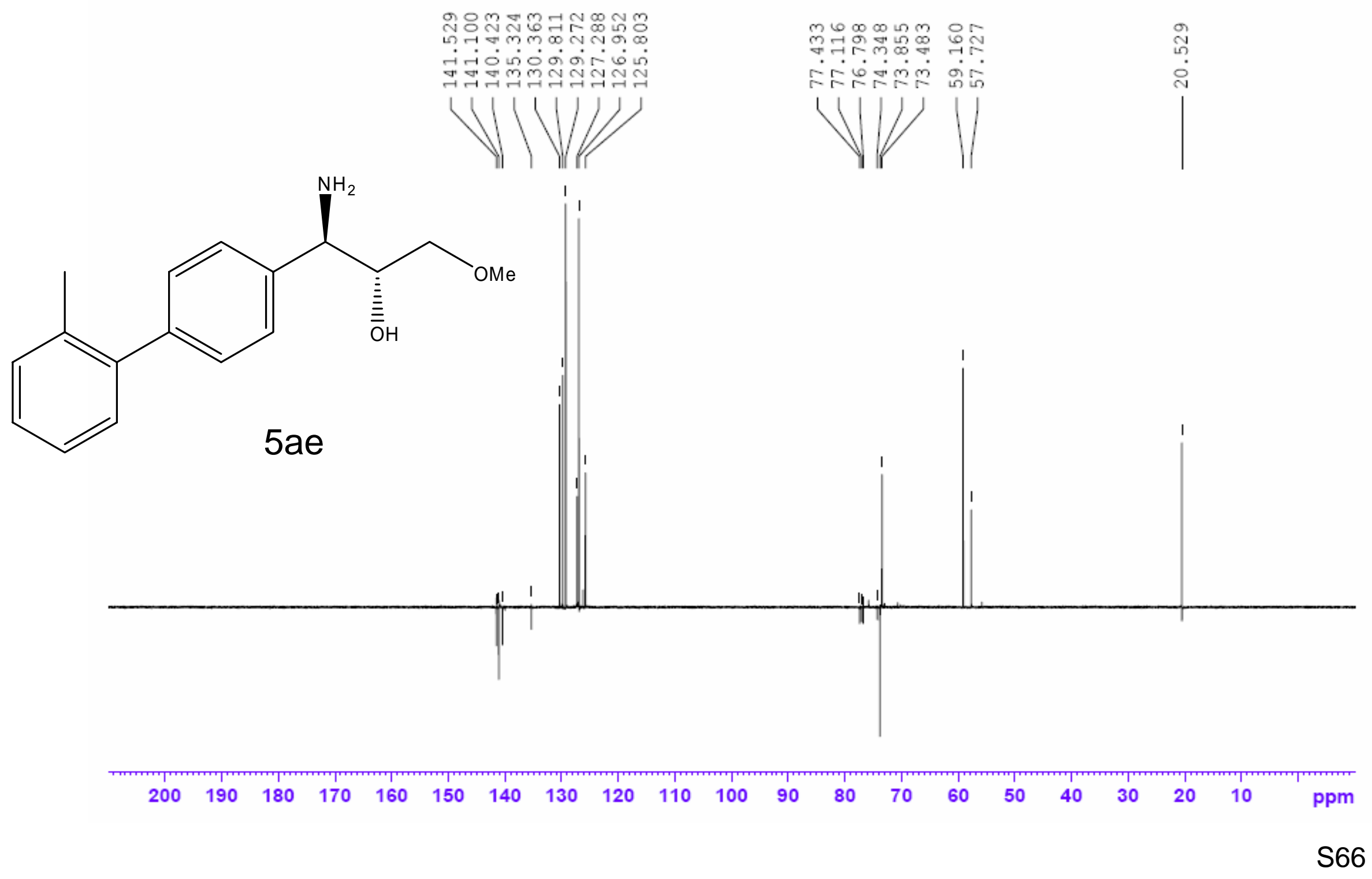



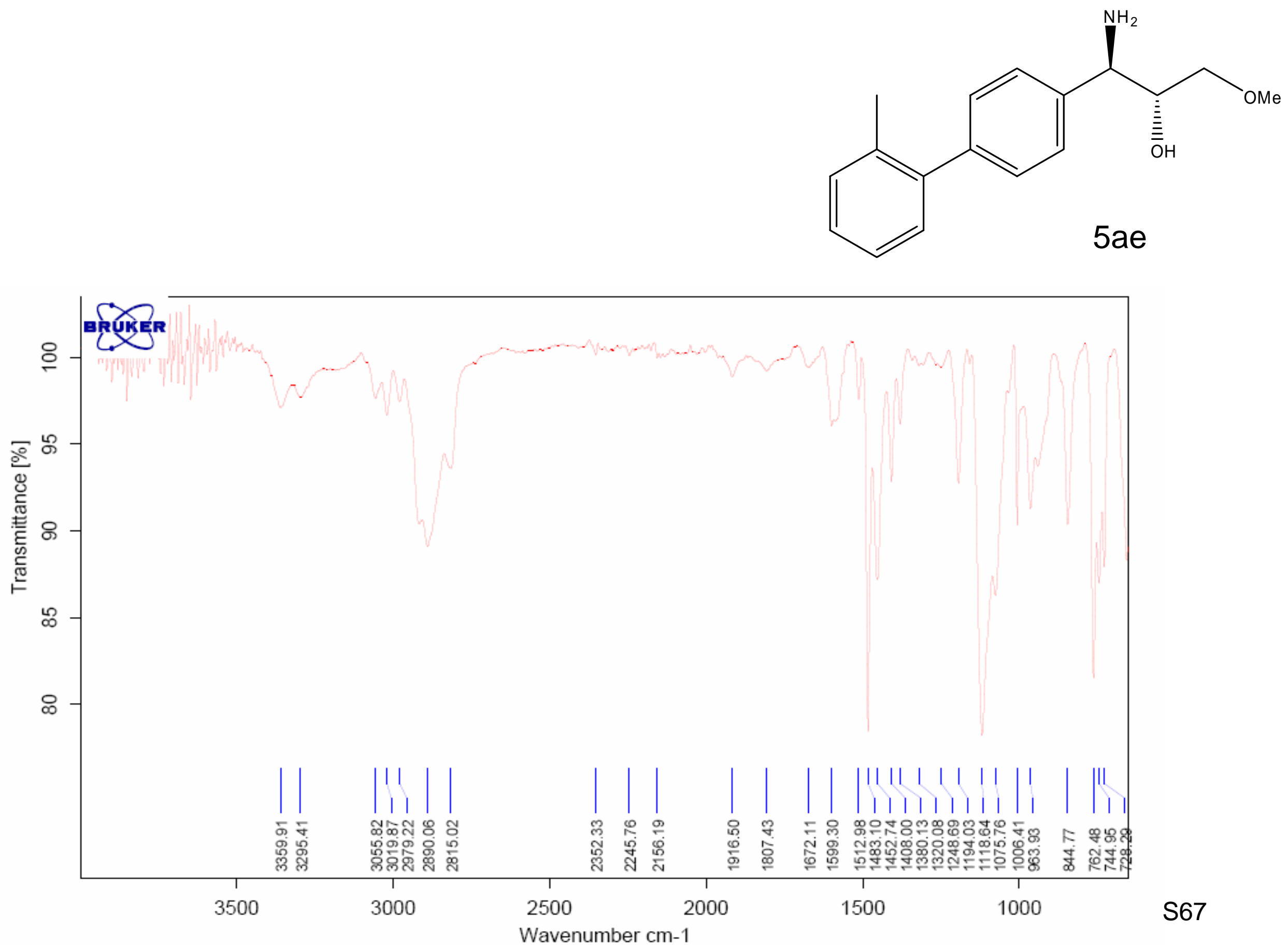


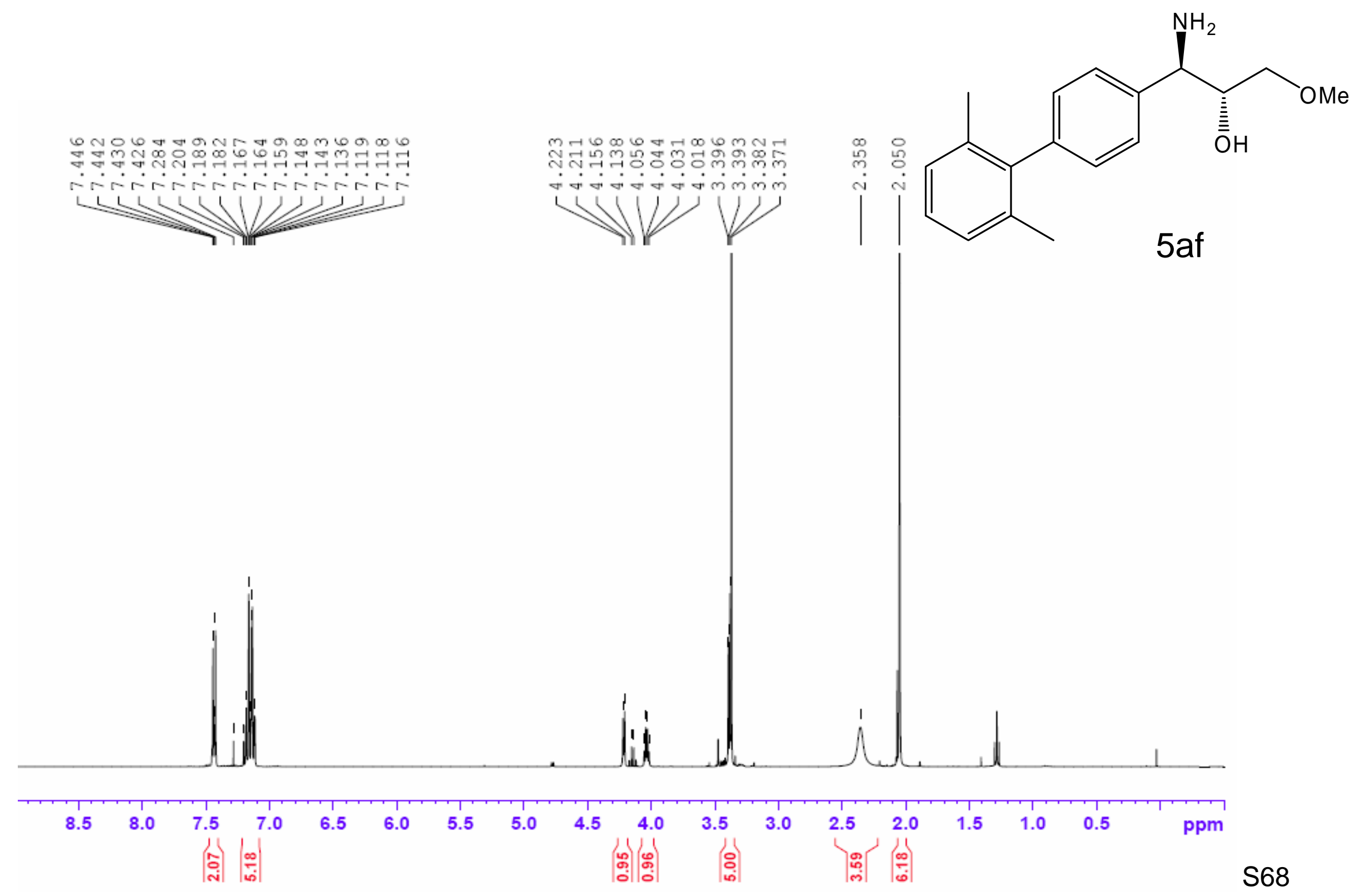




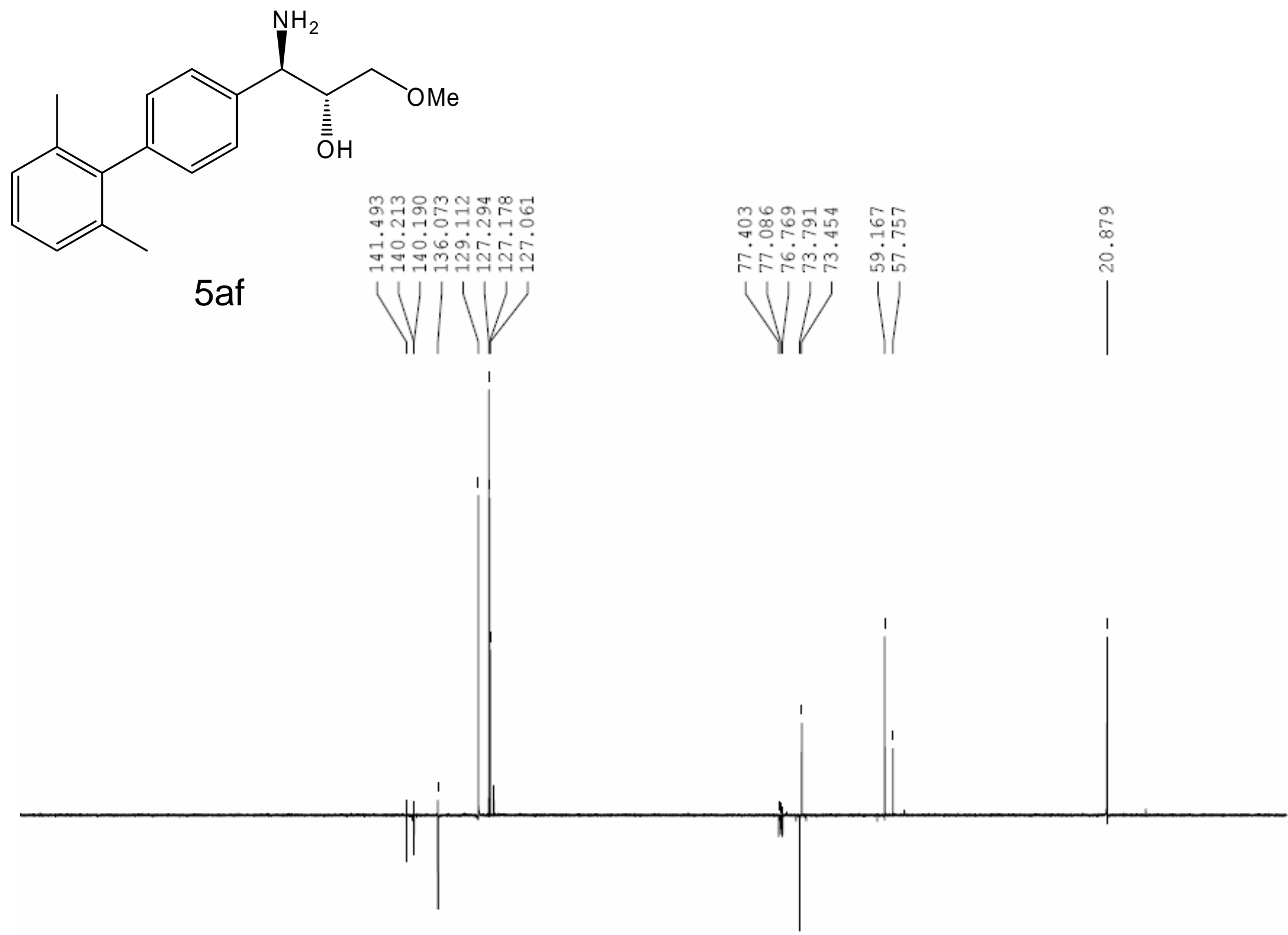

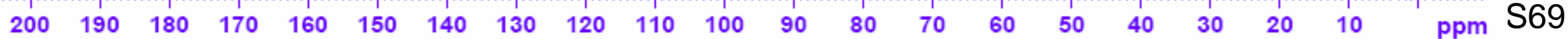




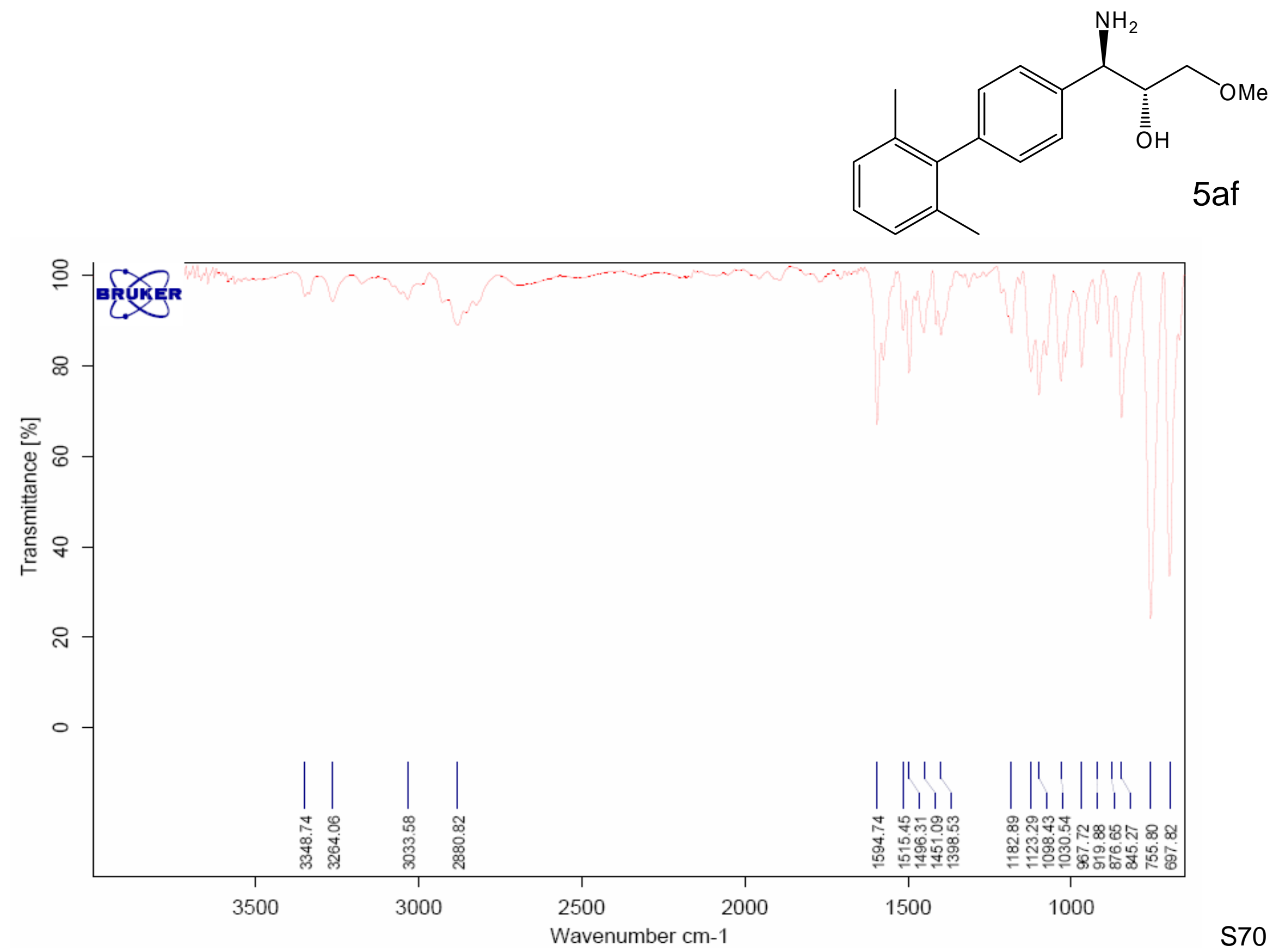




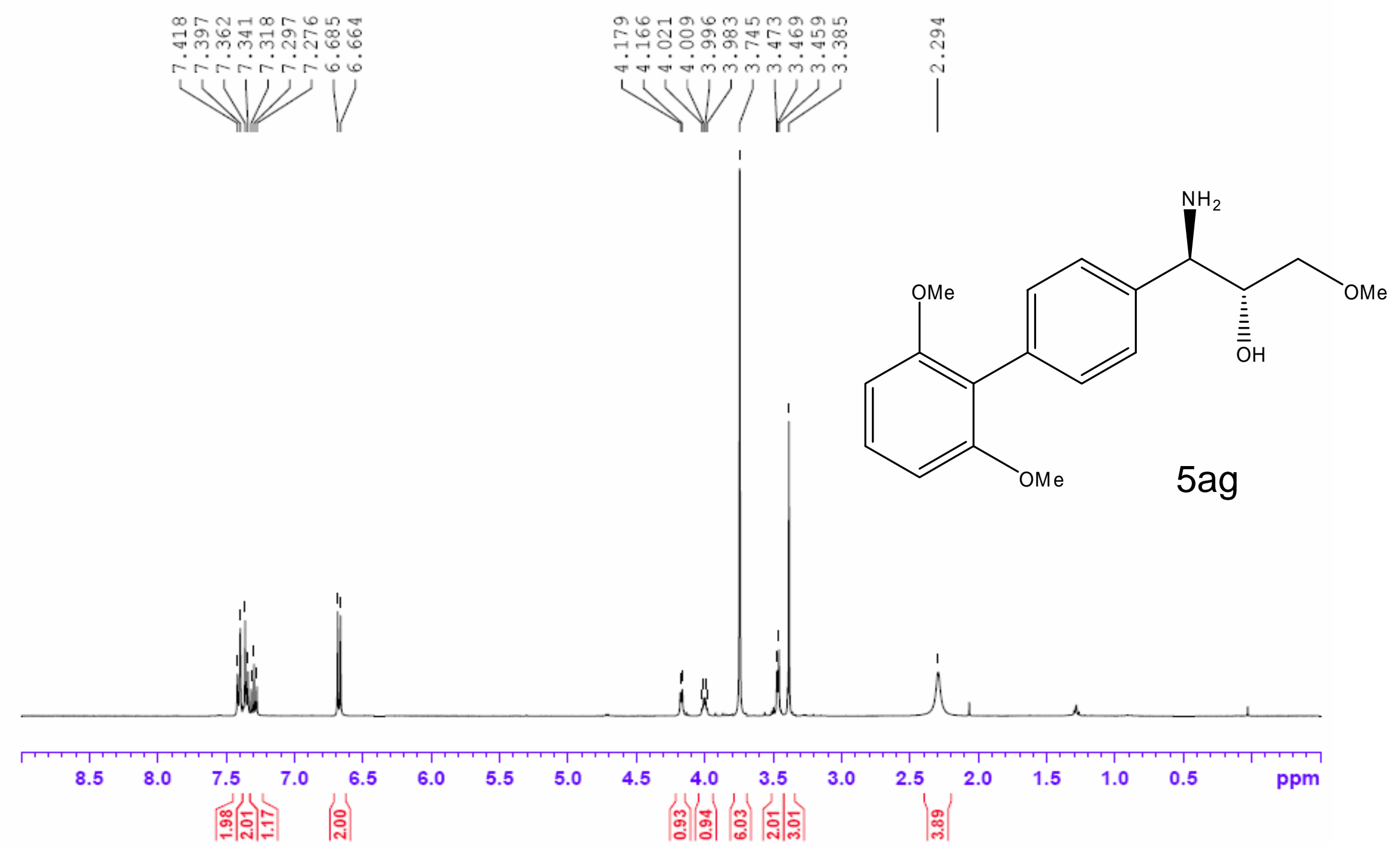




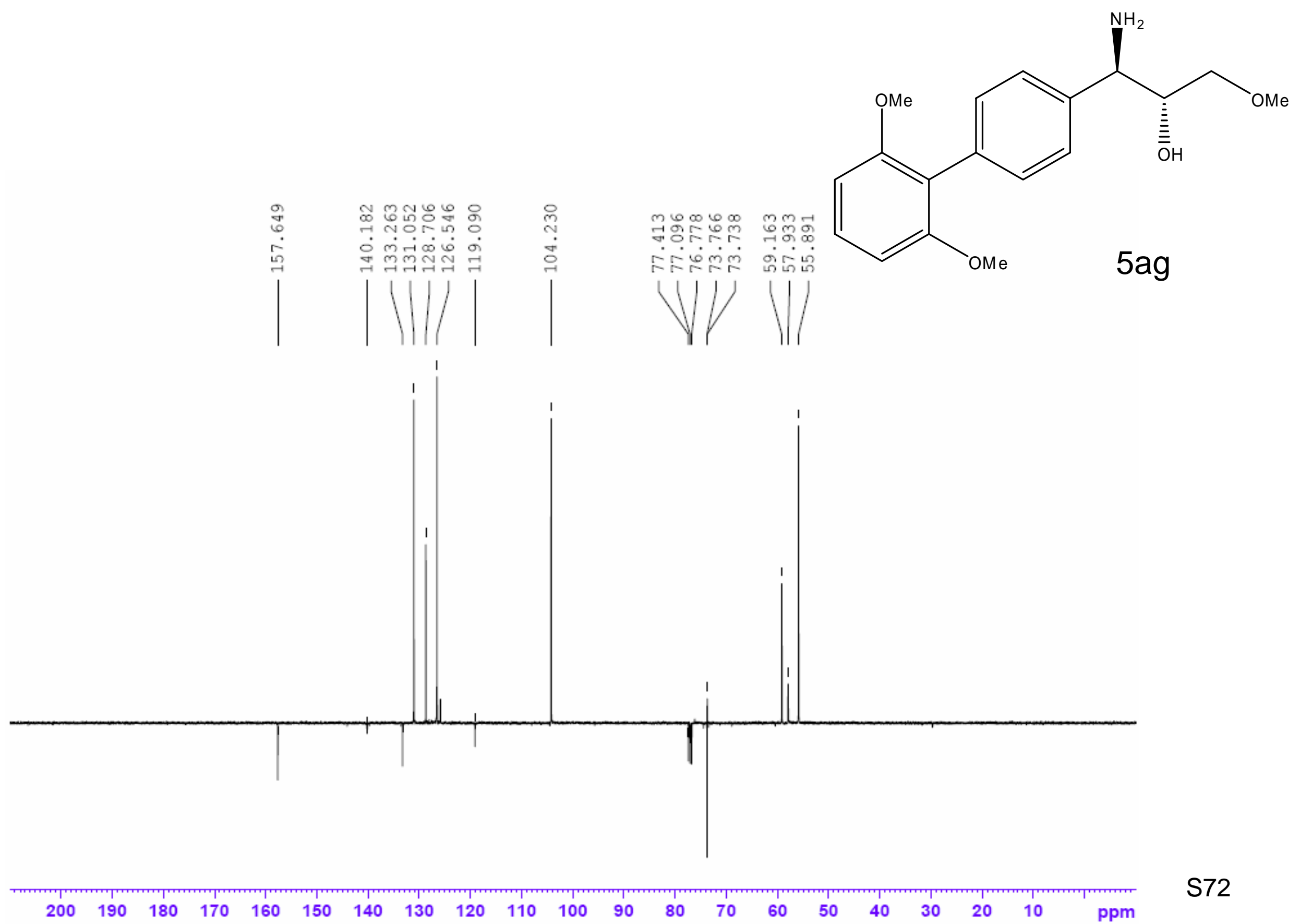



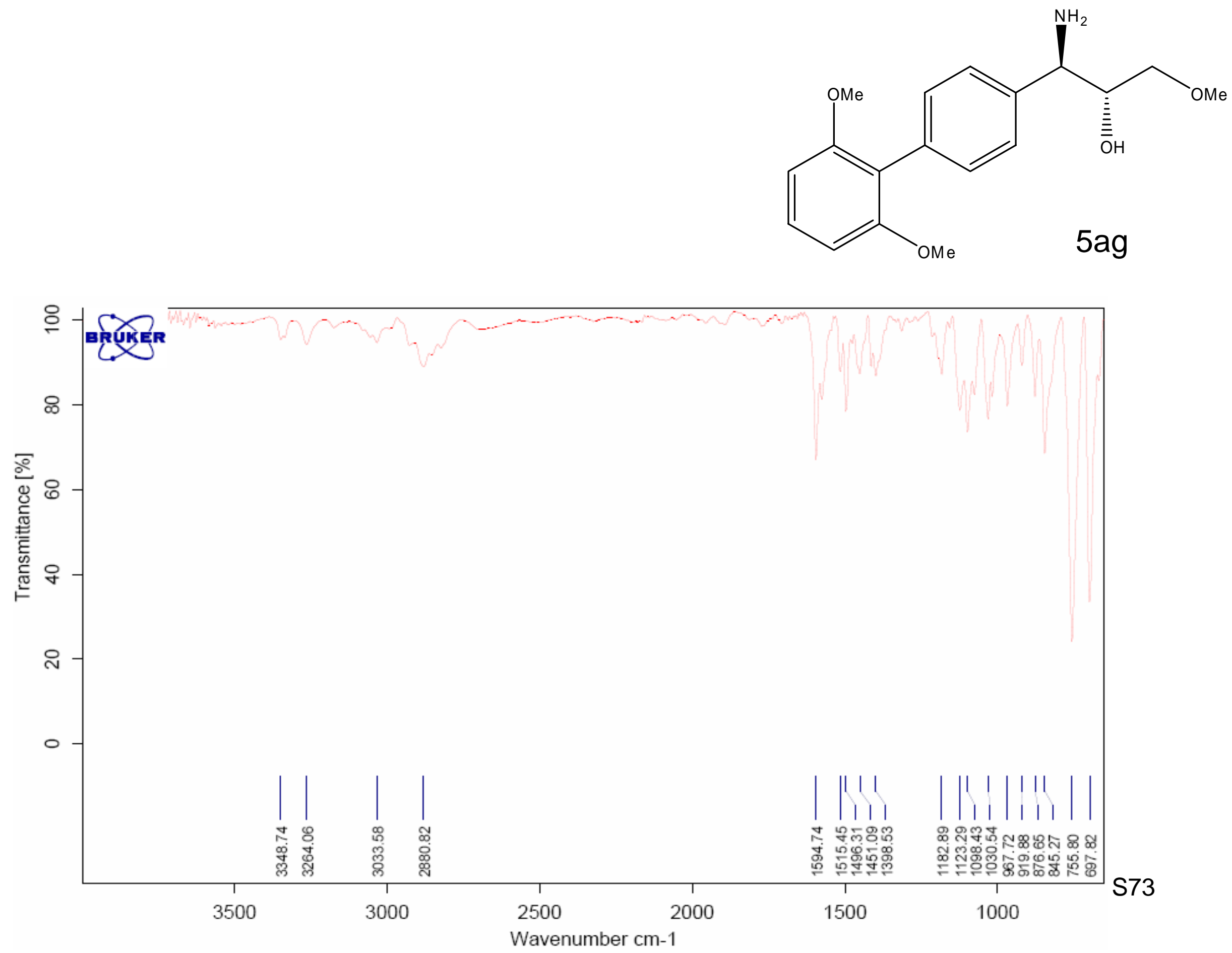

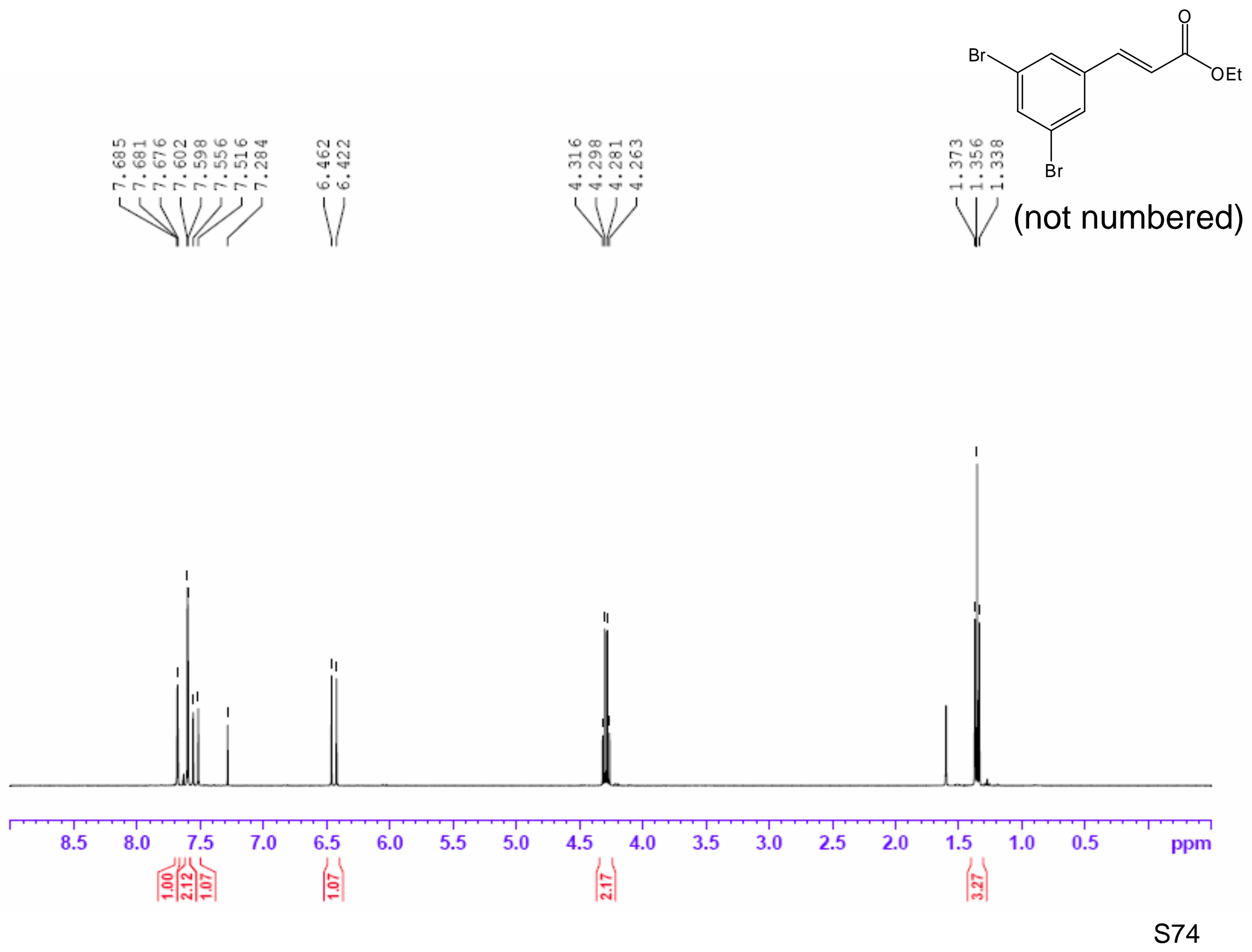


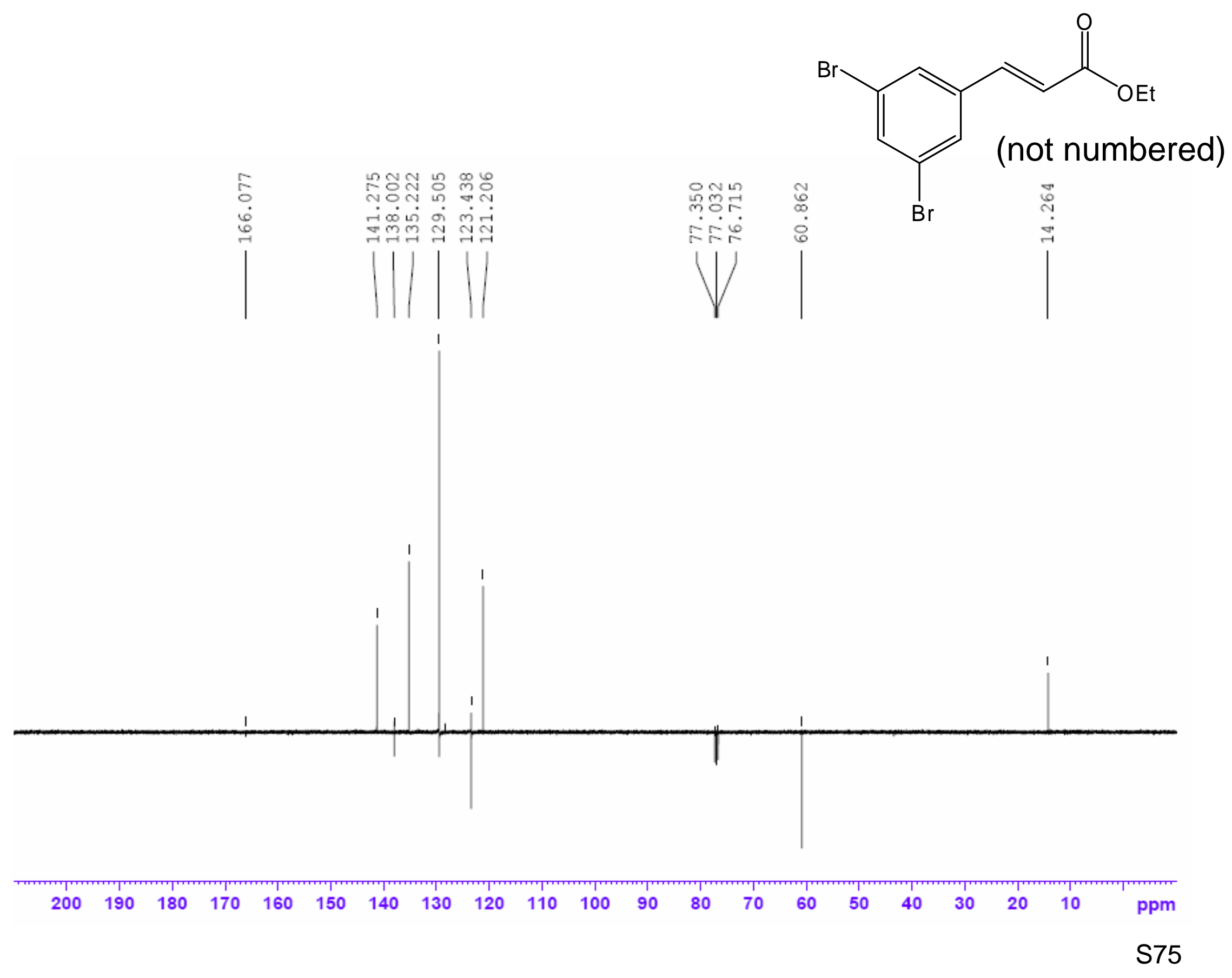




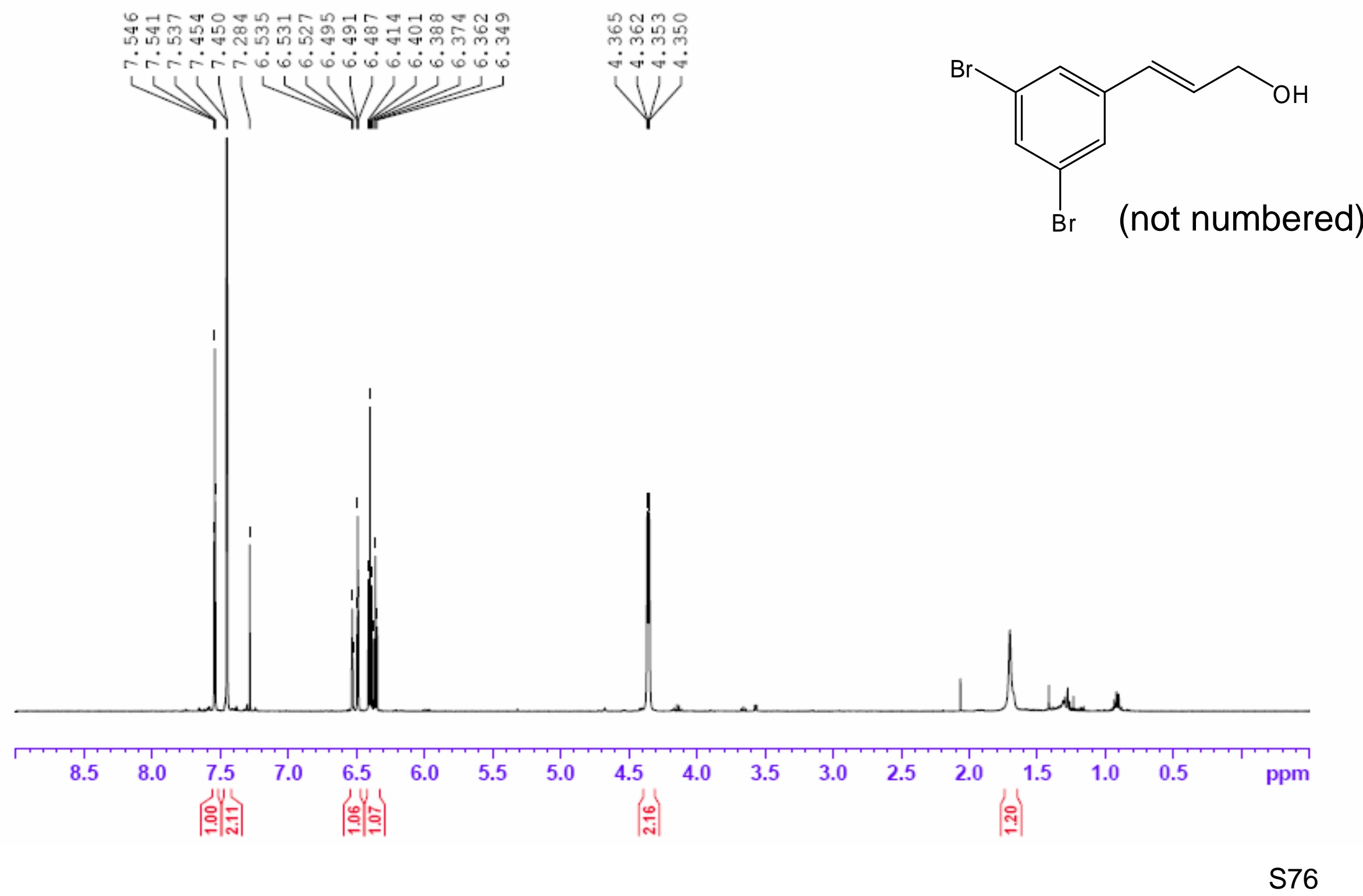




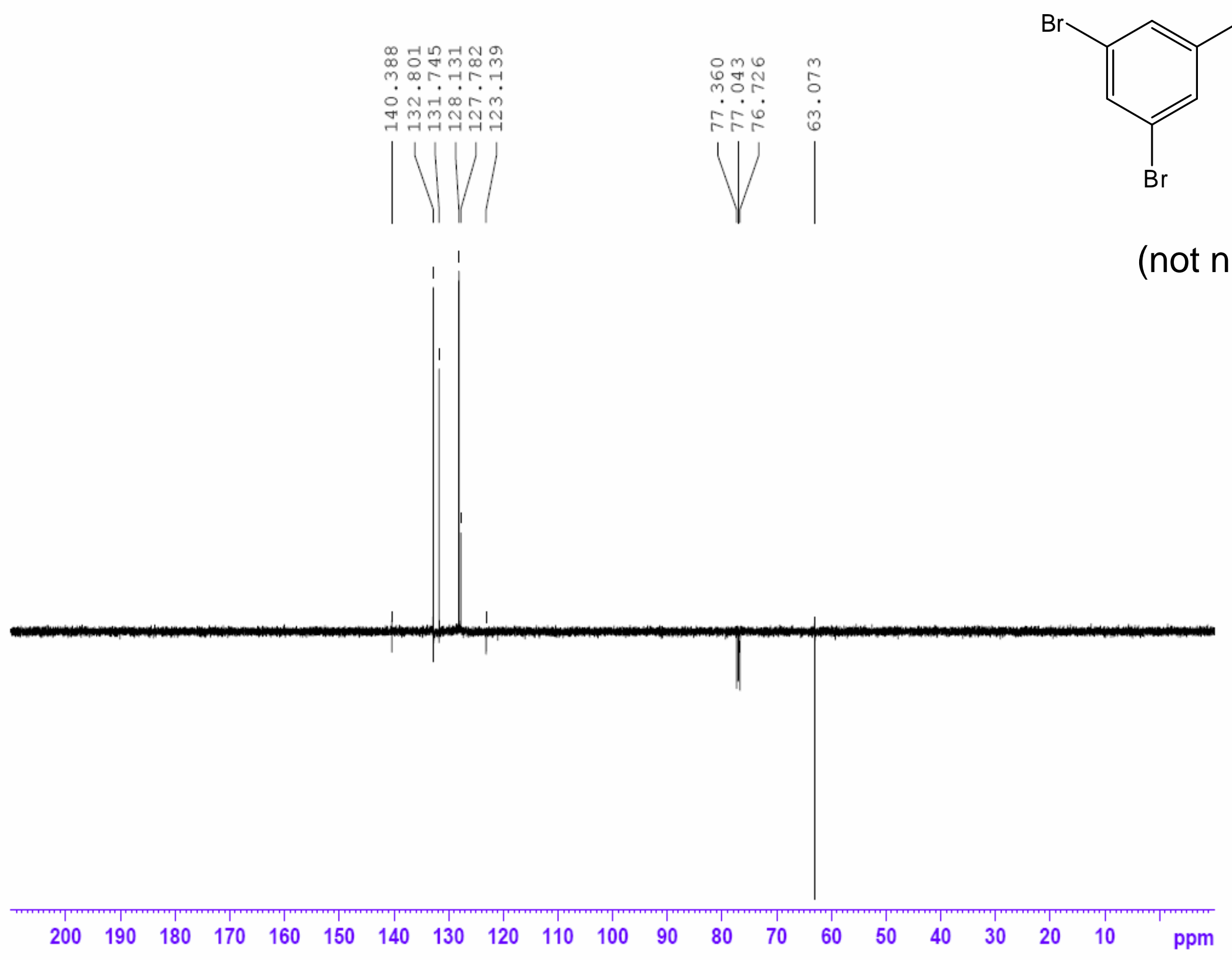




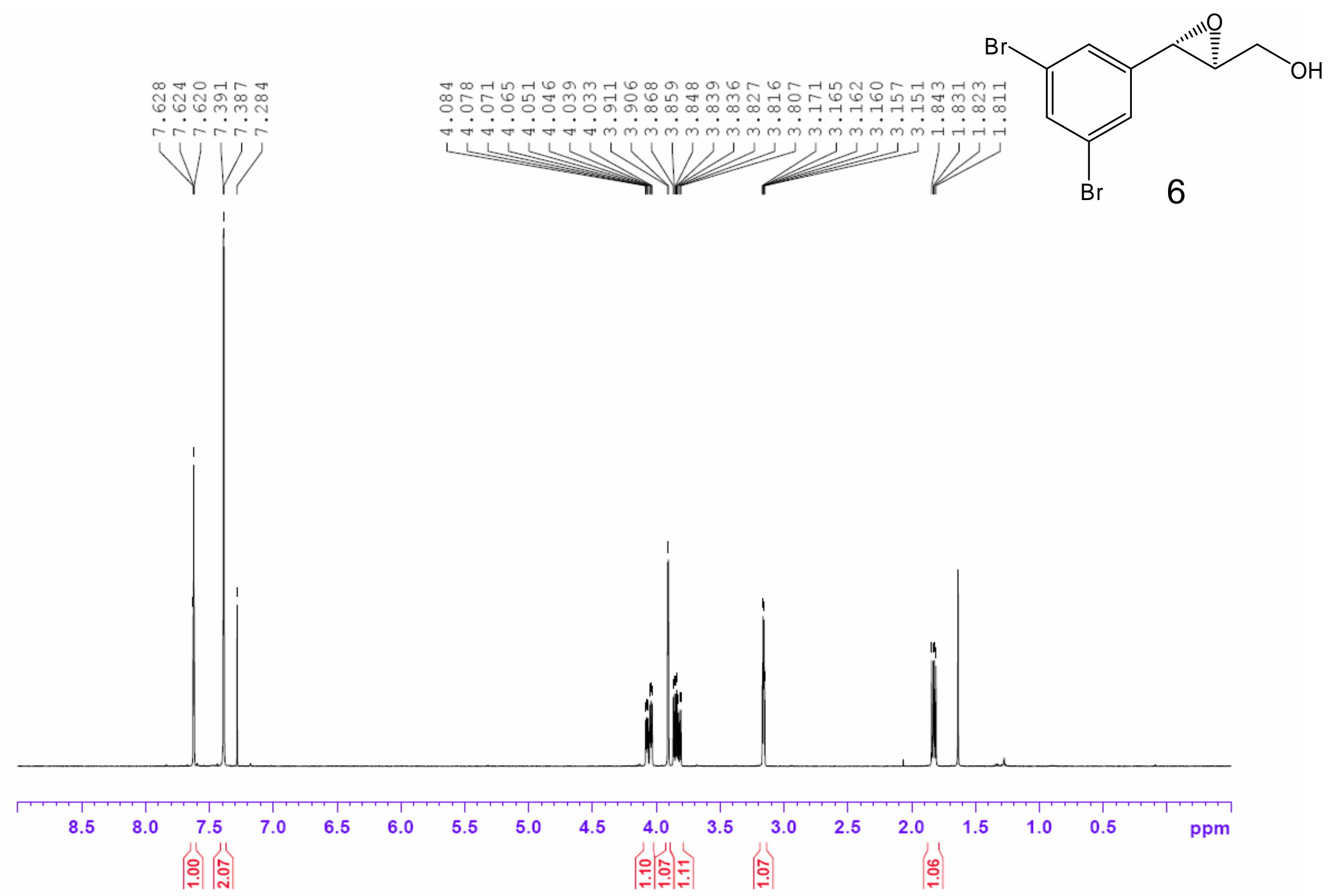




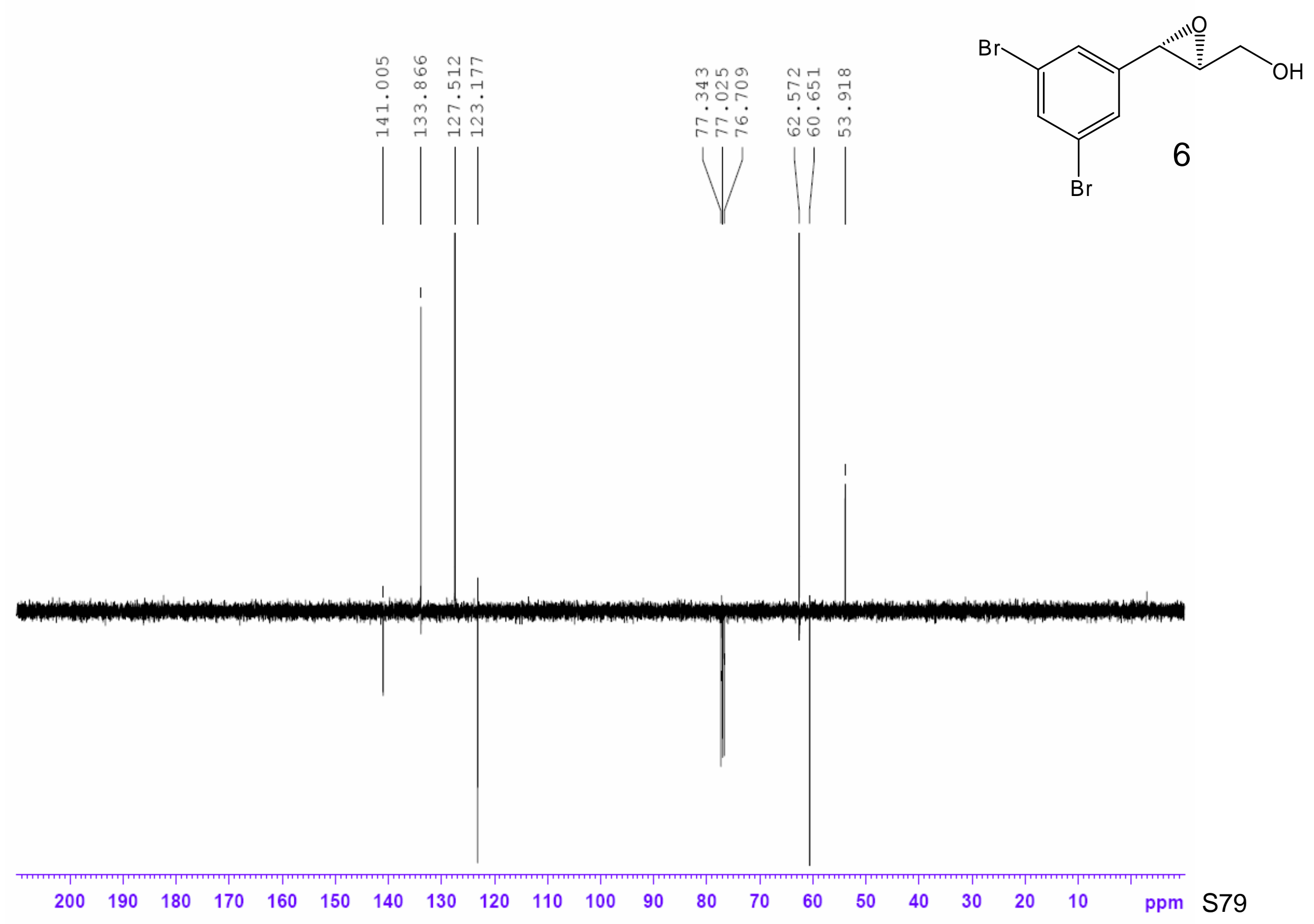




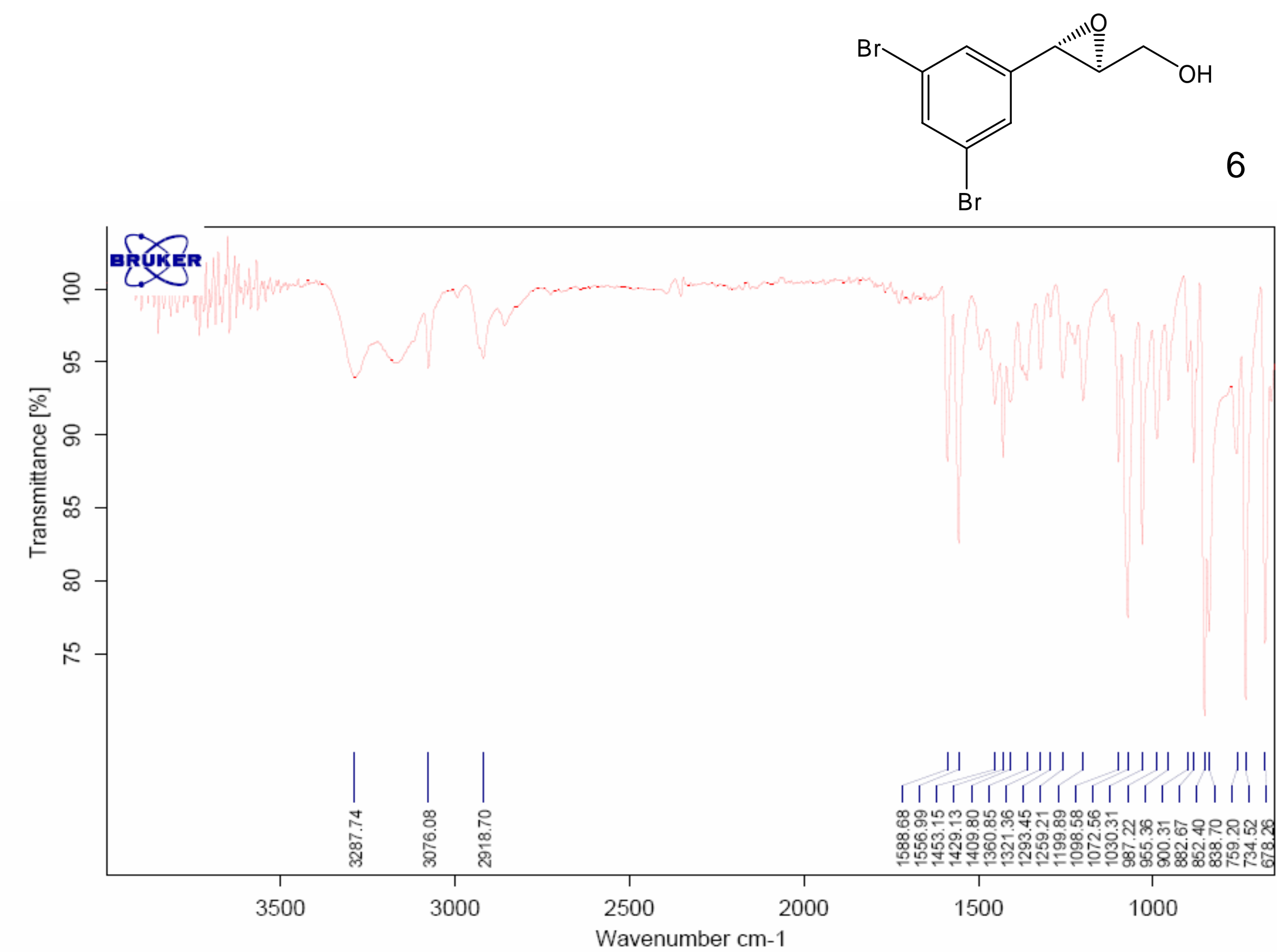




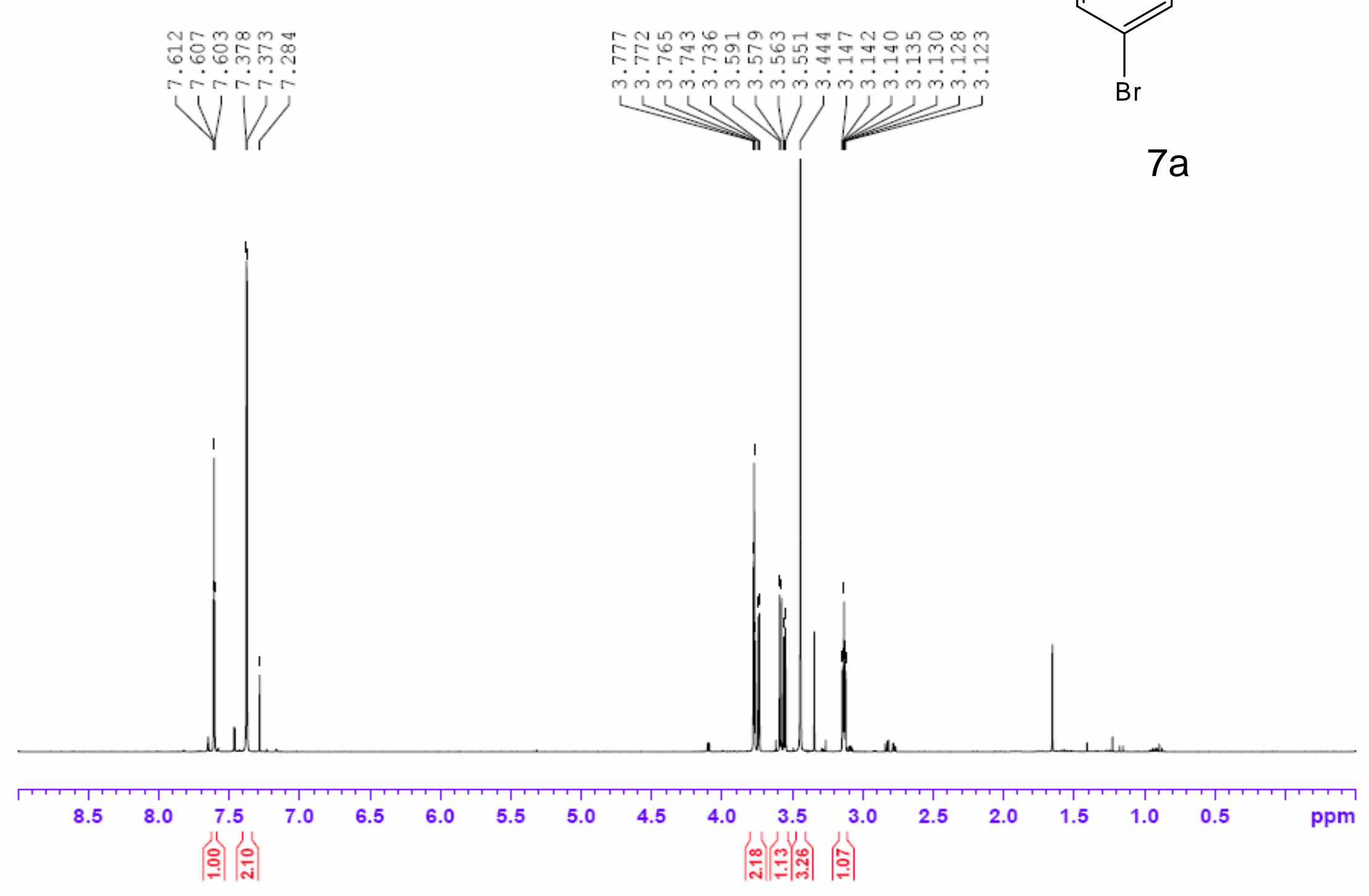




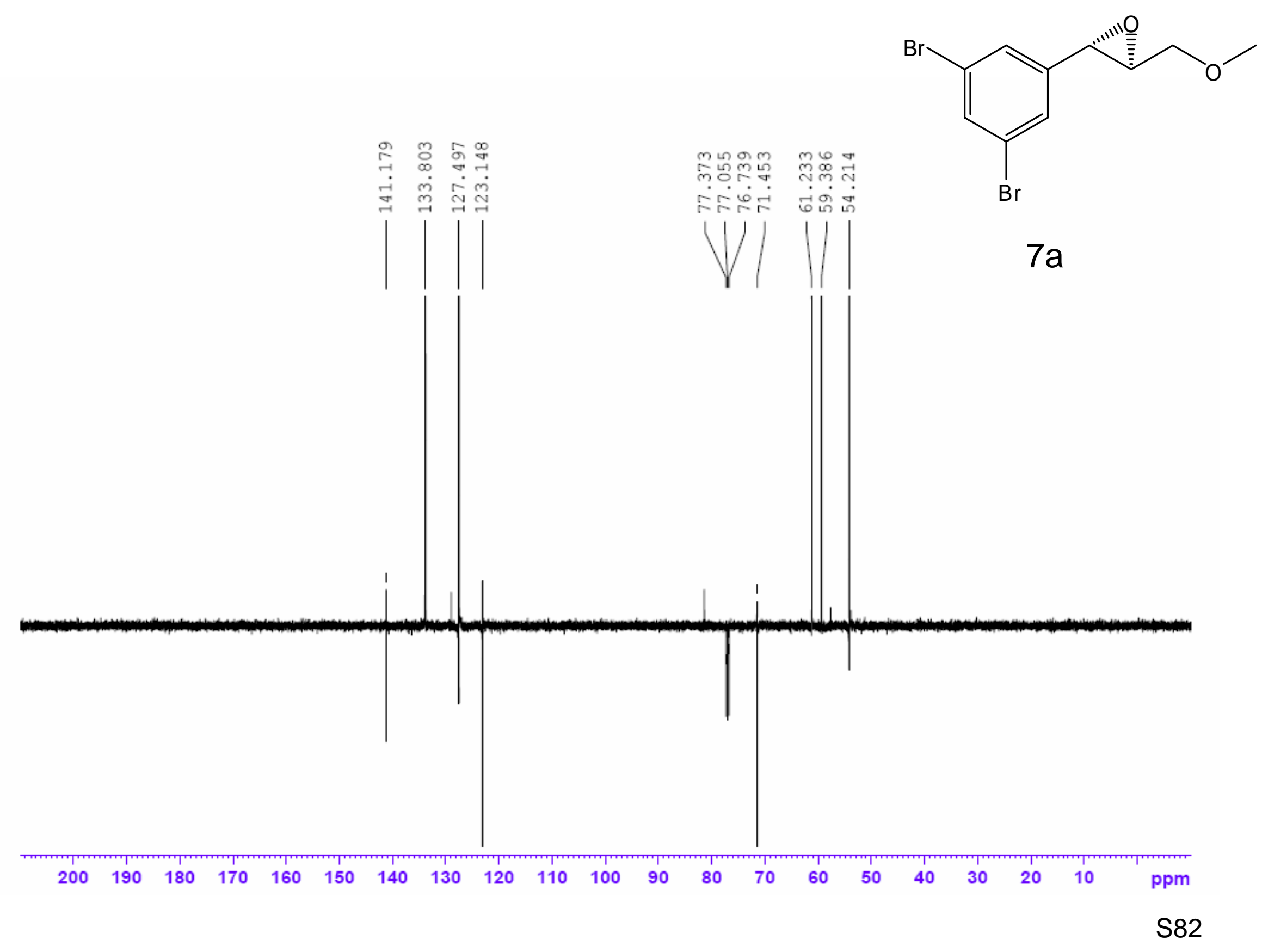



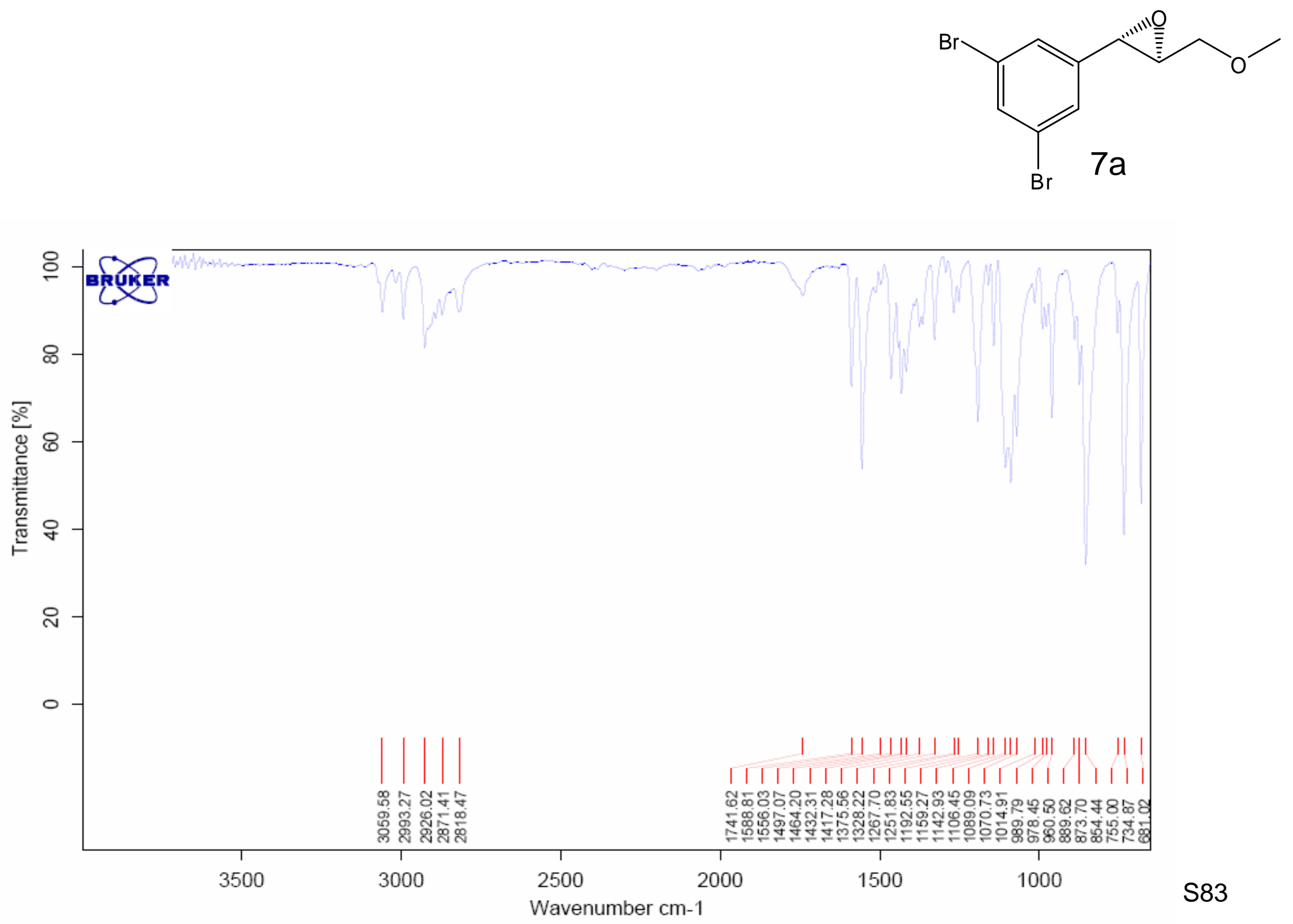


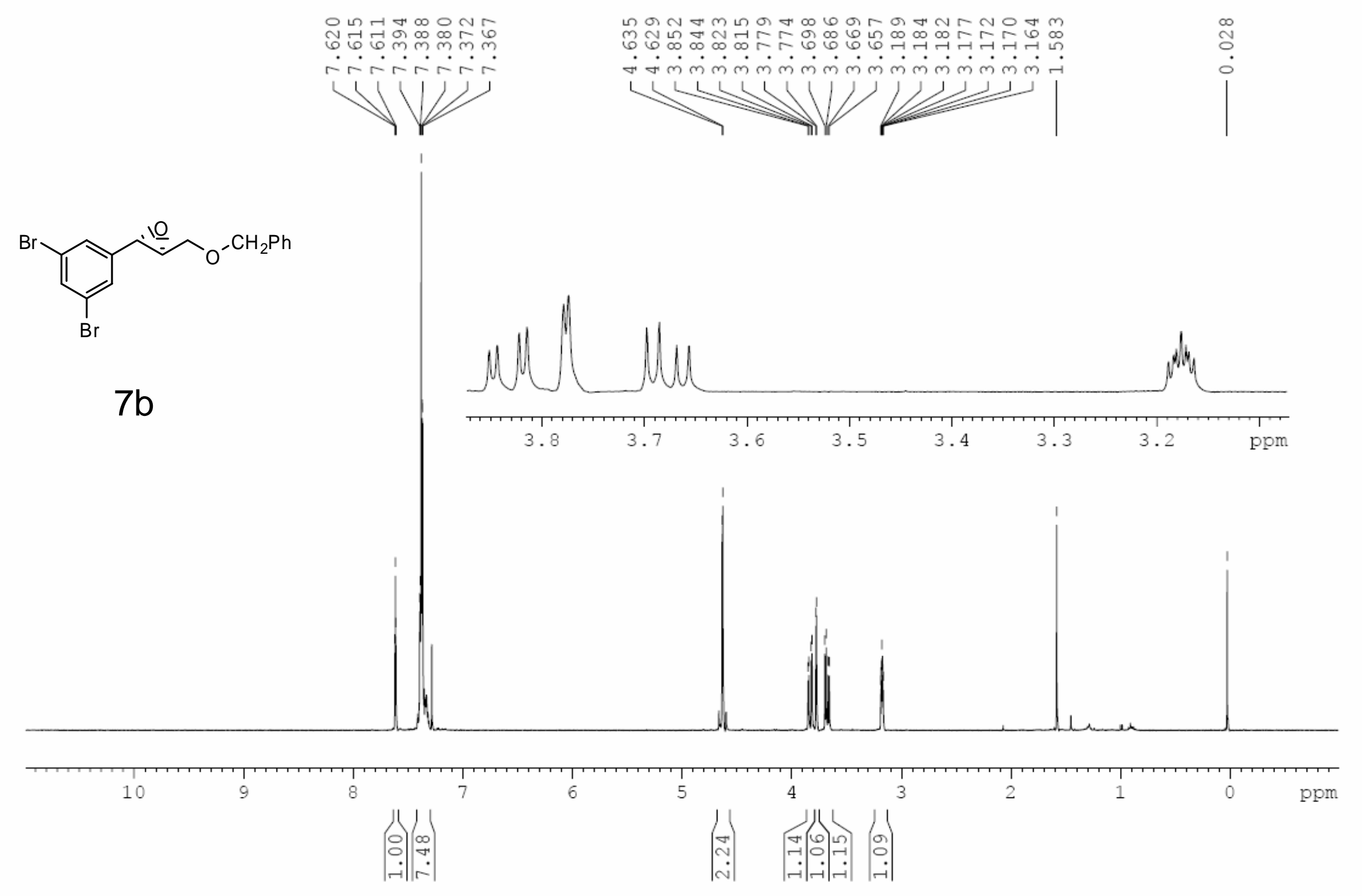




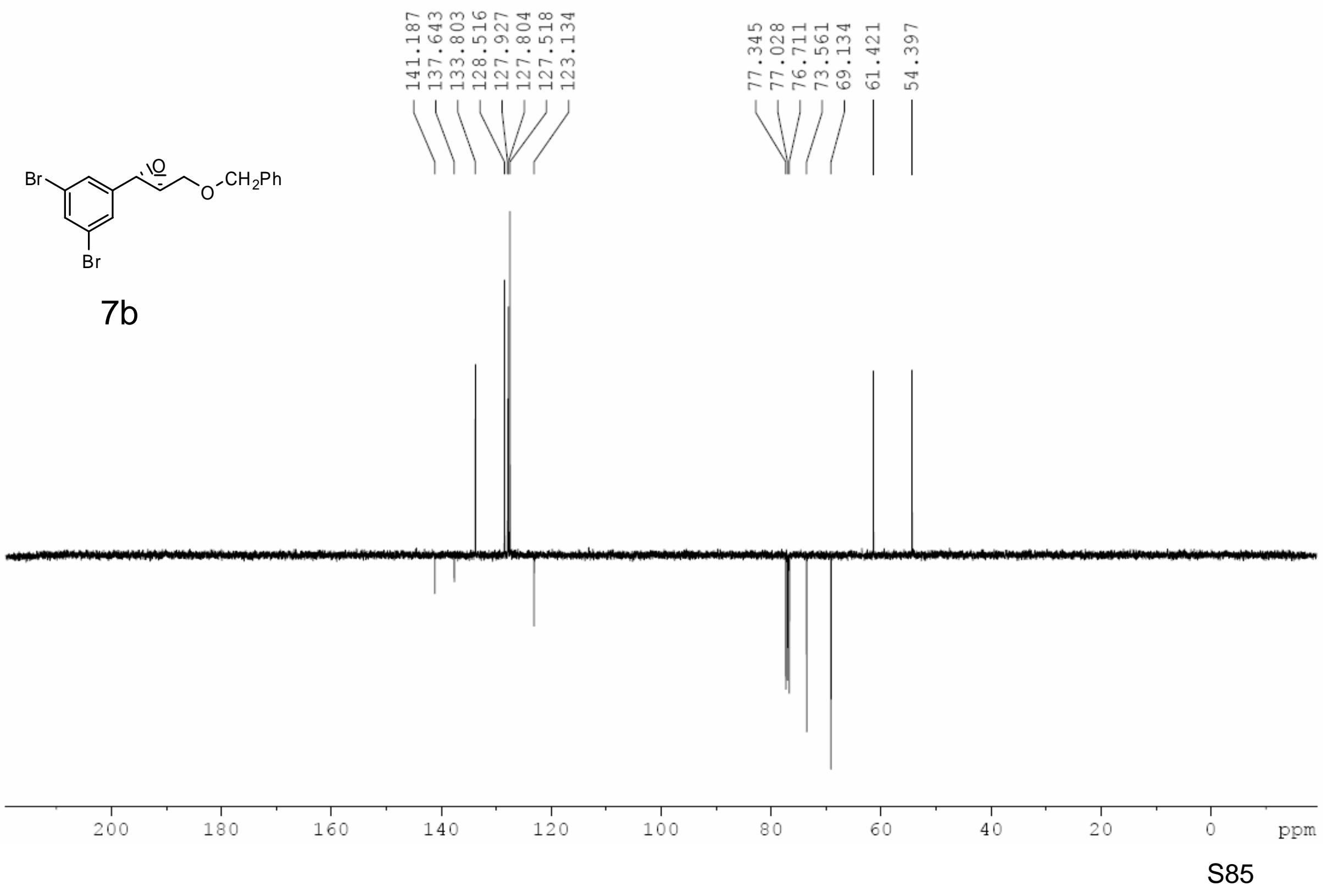




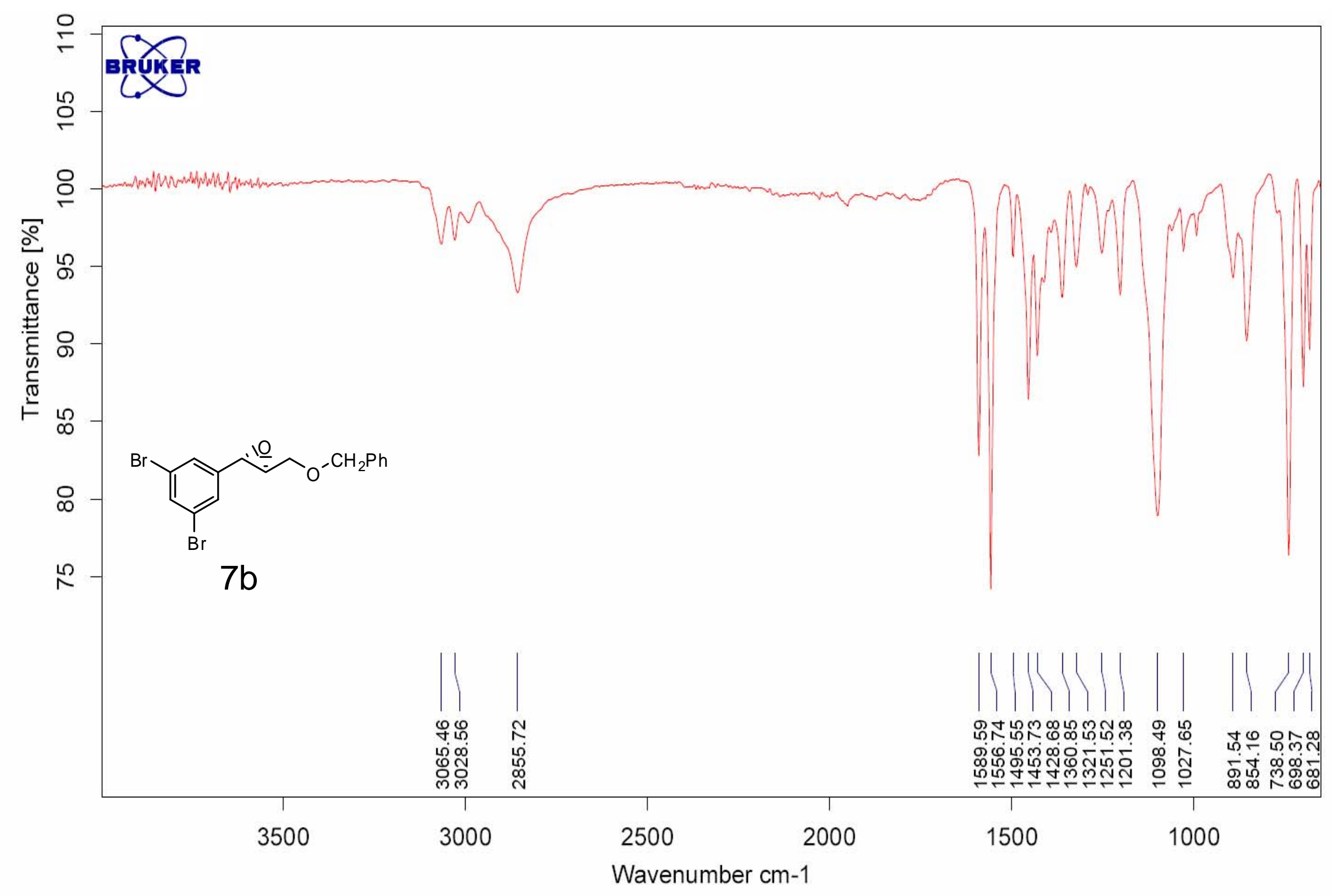




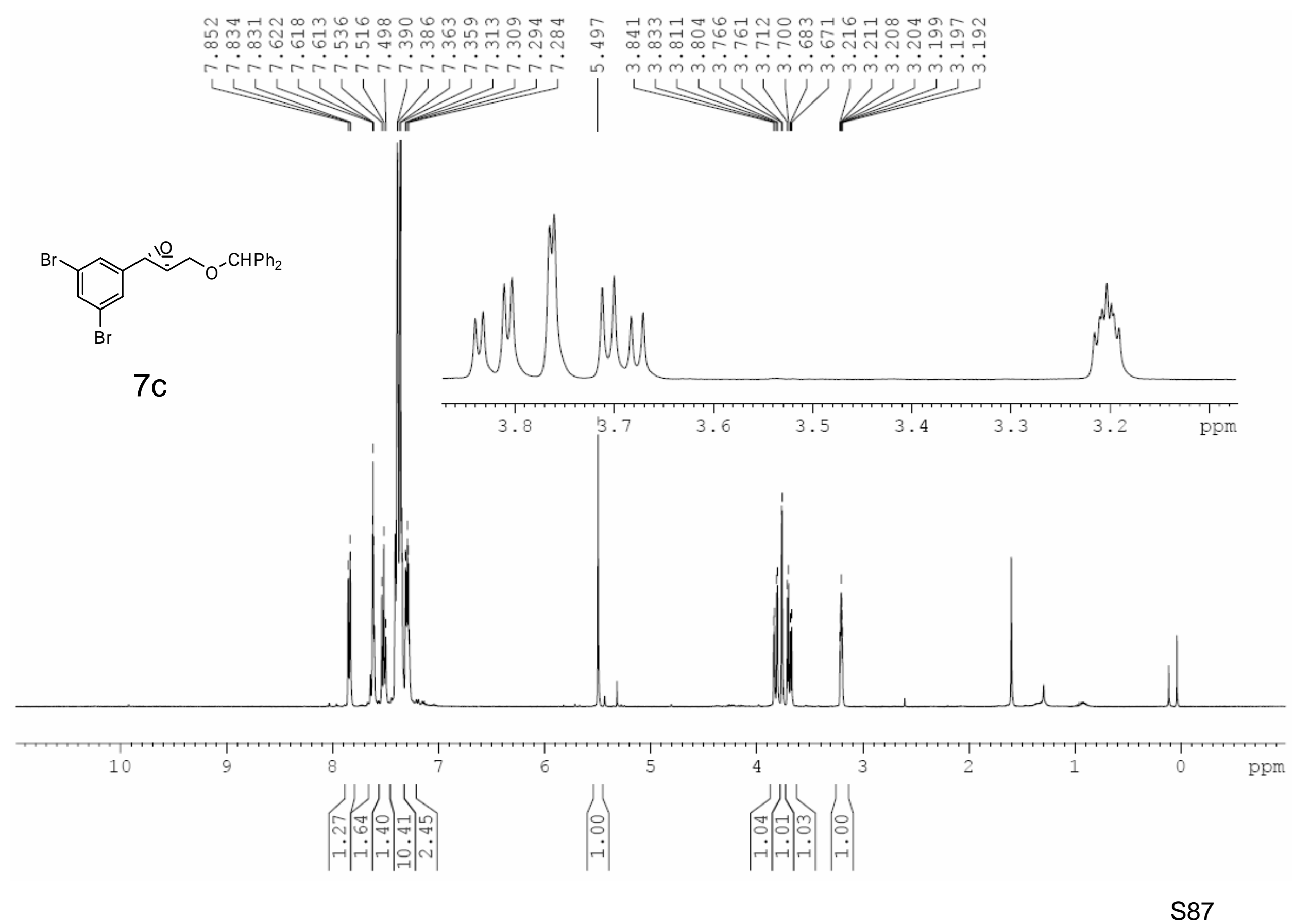


क ஏ न

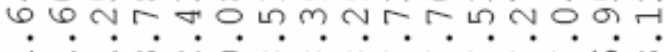

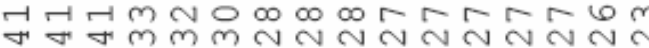

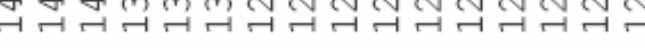

surem

nin

$7 c$

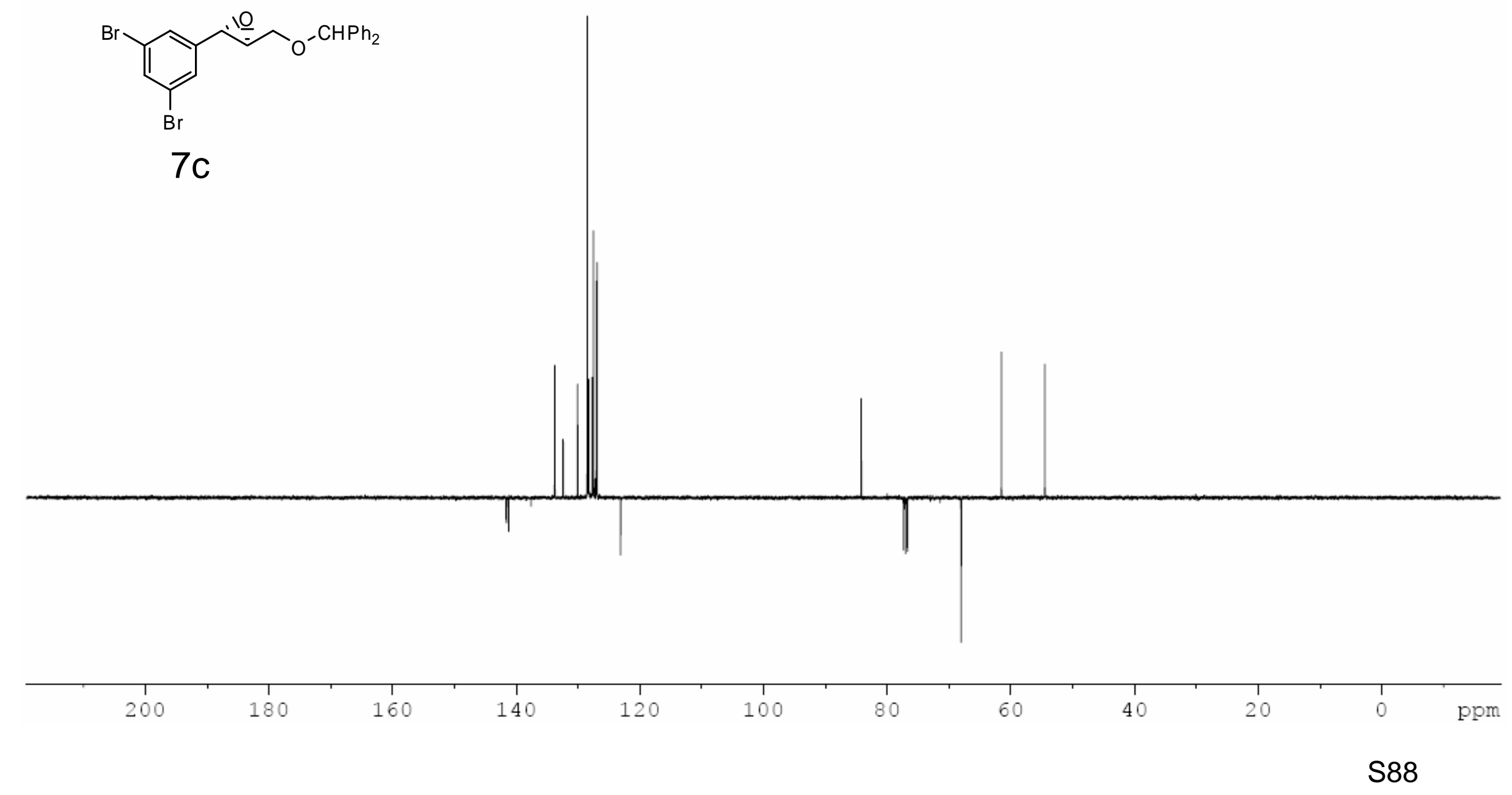

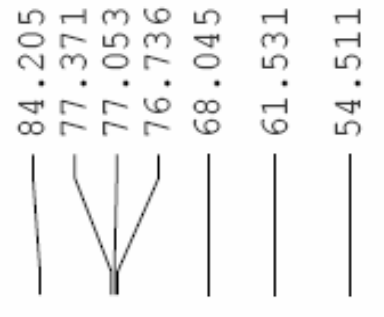

तmor n?

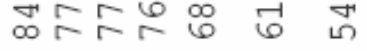

$|V|||$ 


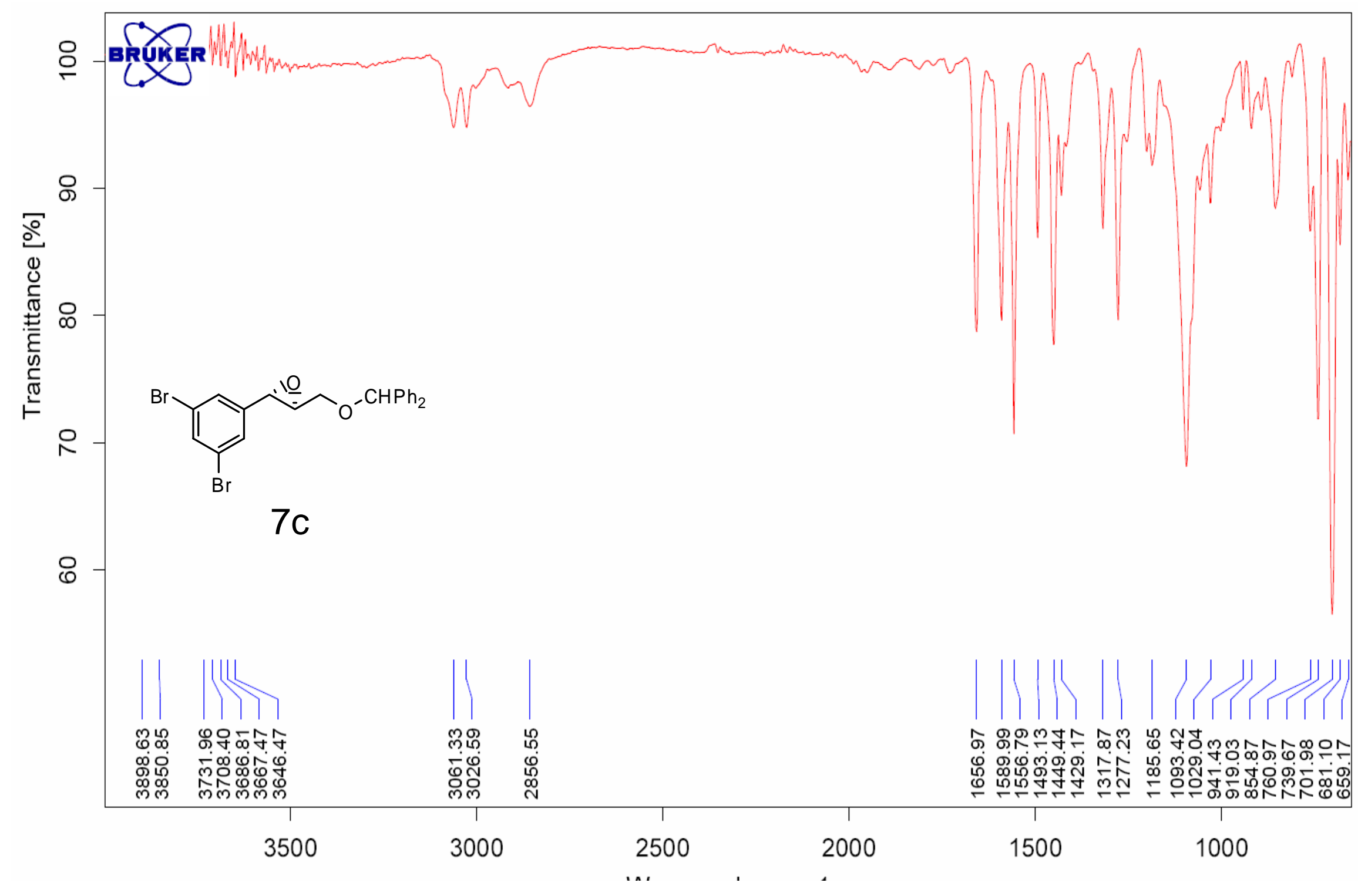




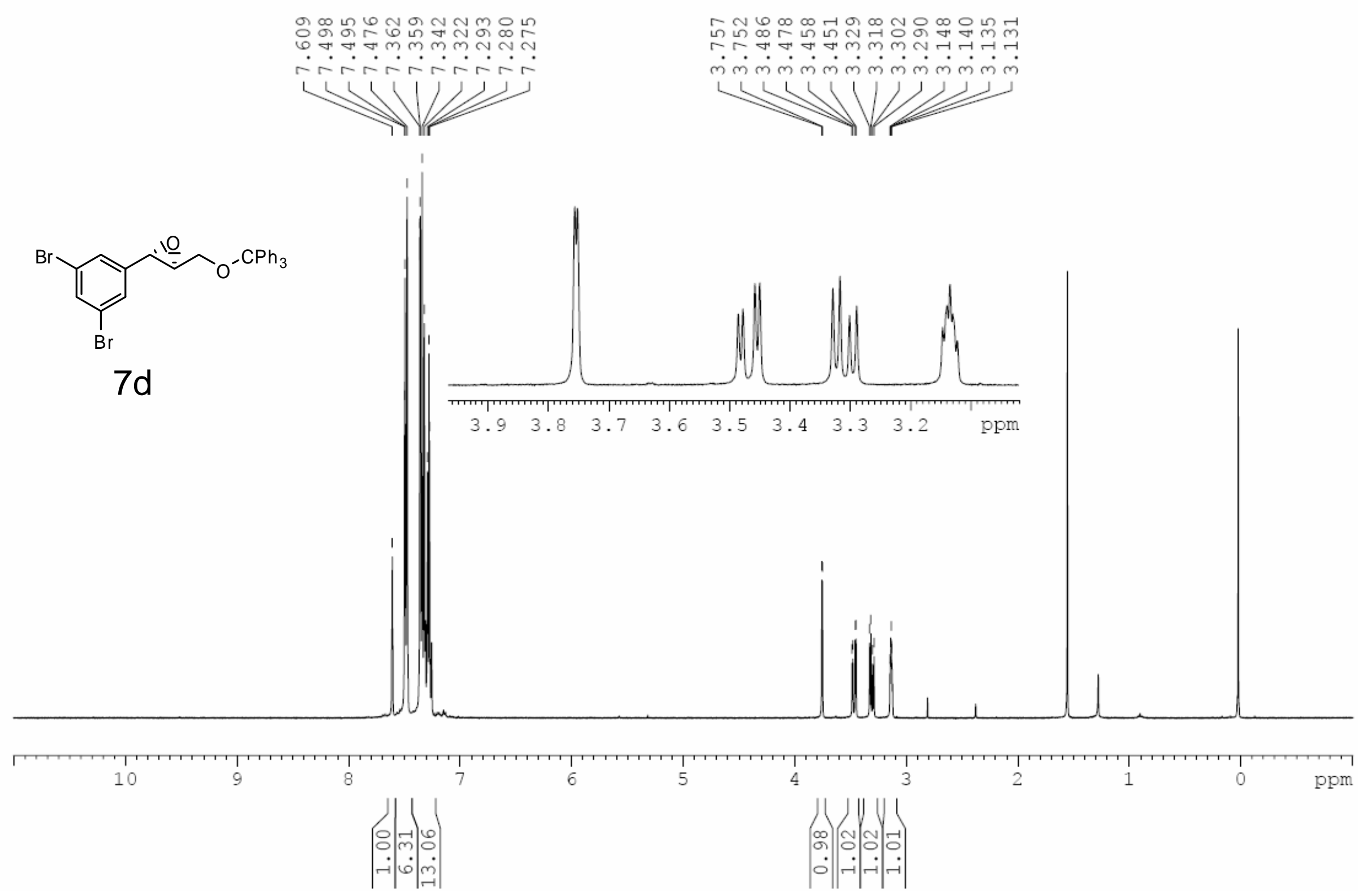



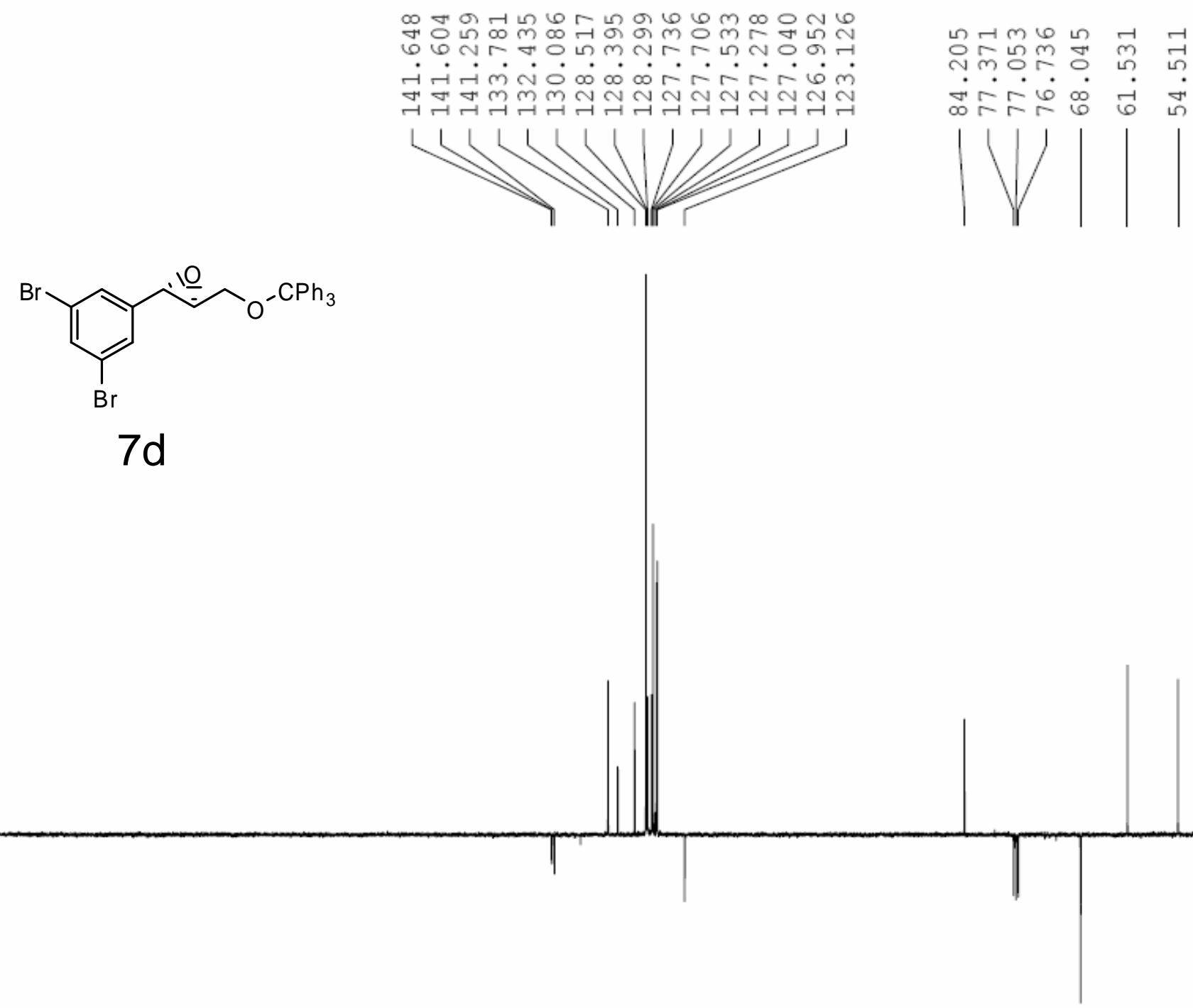

$7 d$

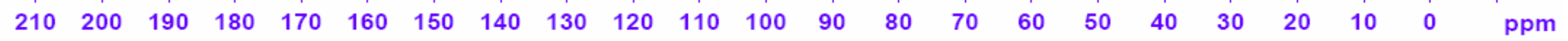




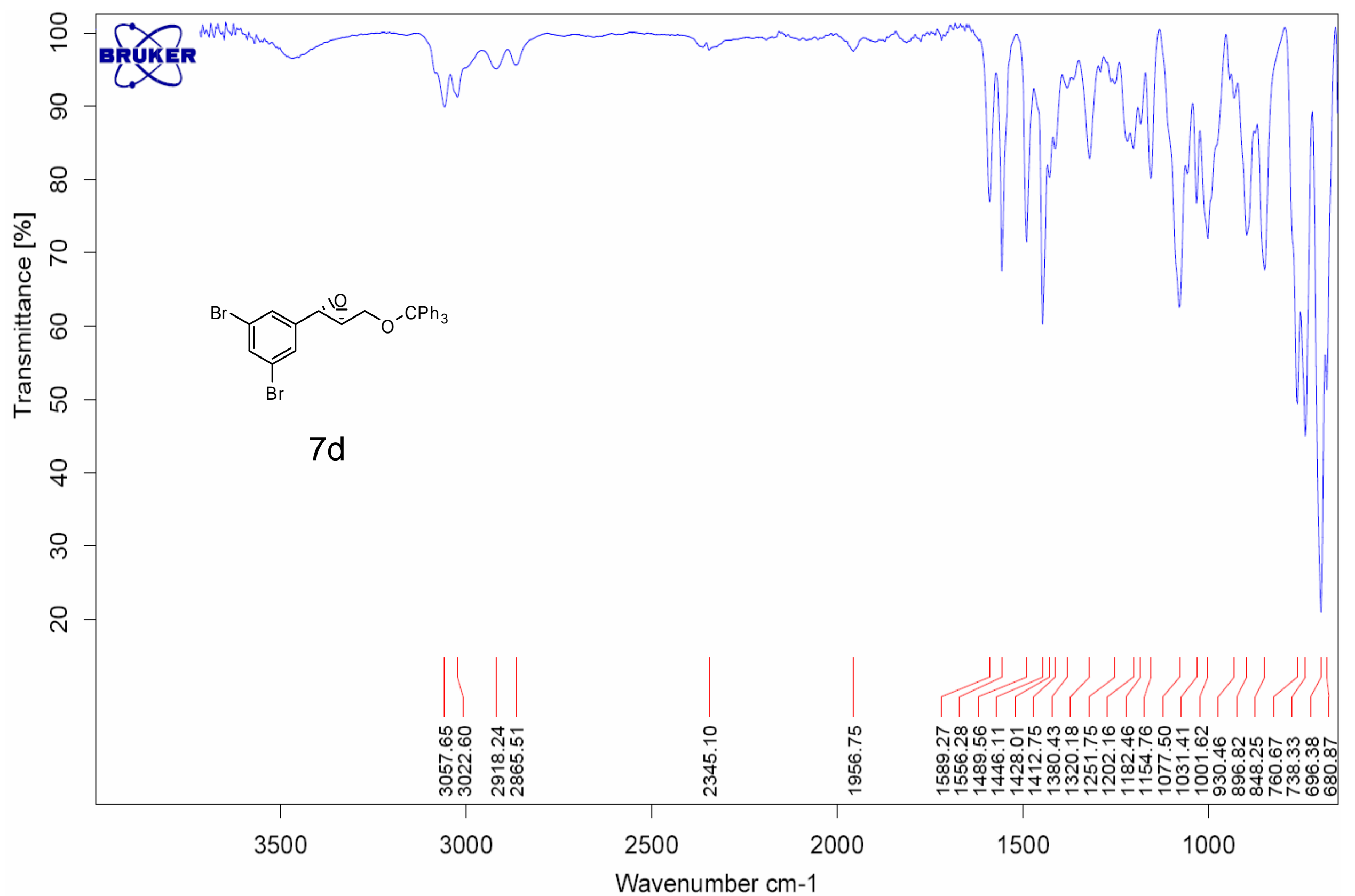




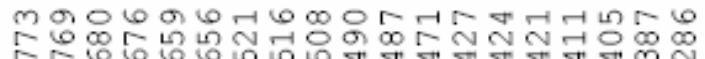

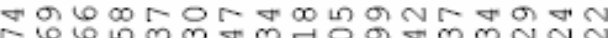

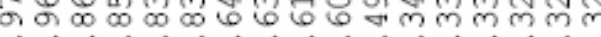

arina.

$\longrightarrow$

ㄱา 11 ir

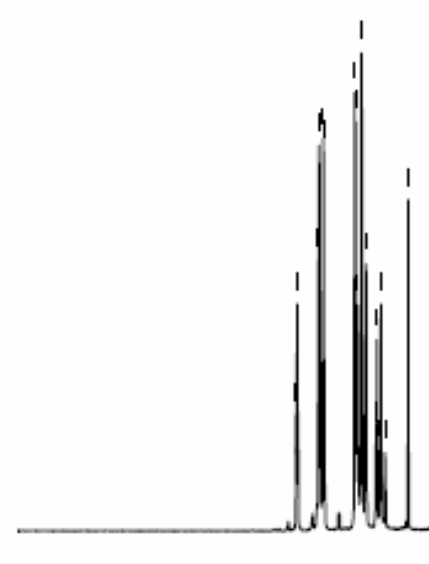

mmmminmmin

301111111

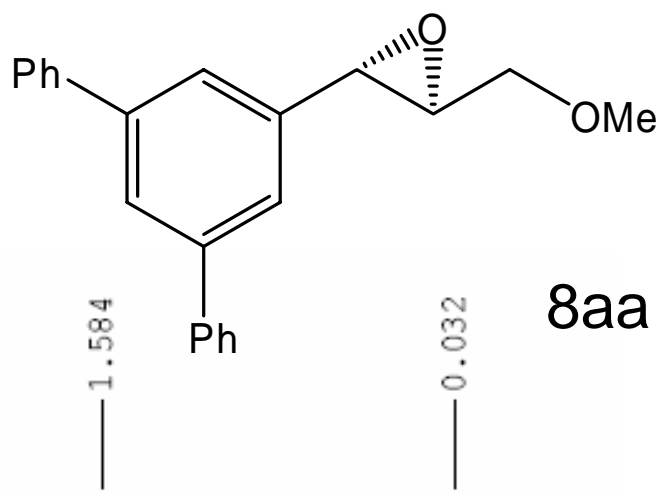

$8.5 \quad 8.0$

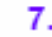

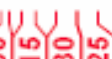

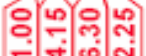




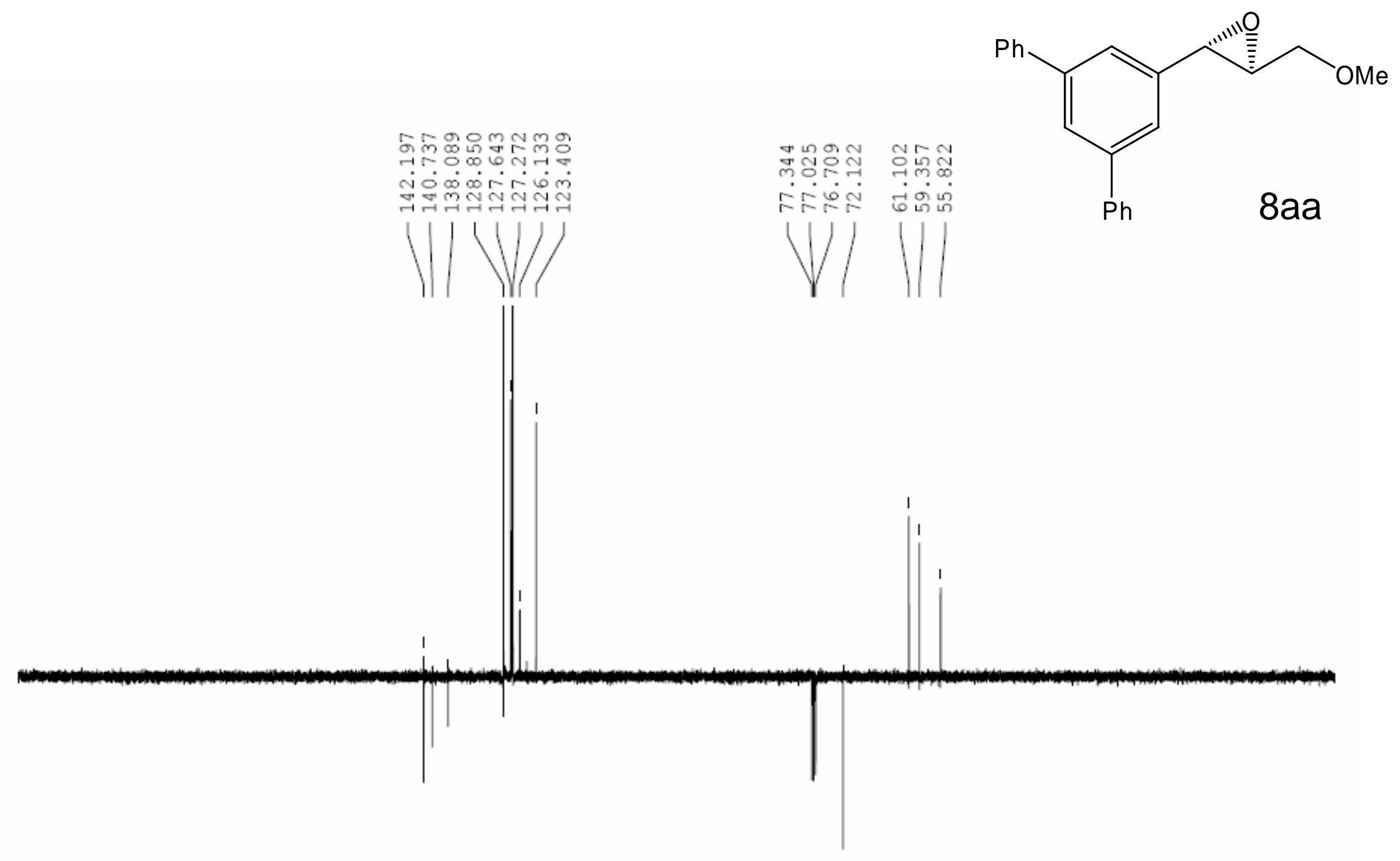

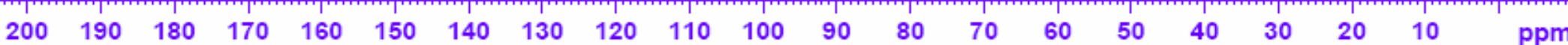



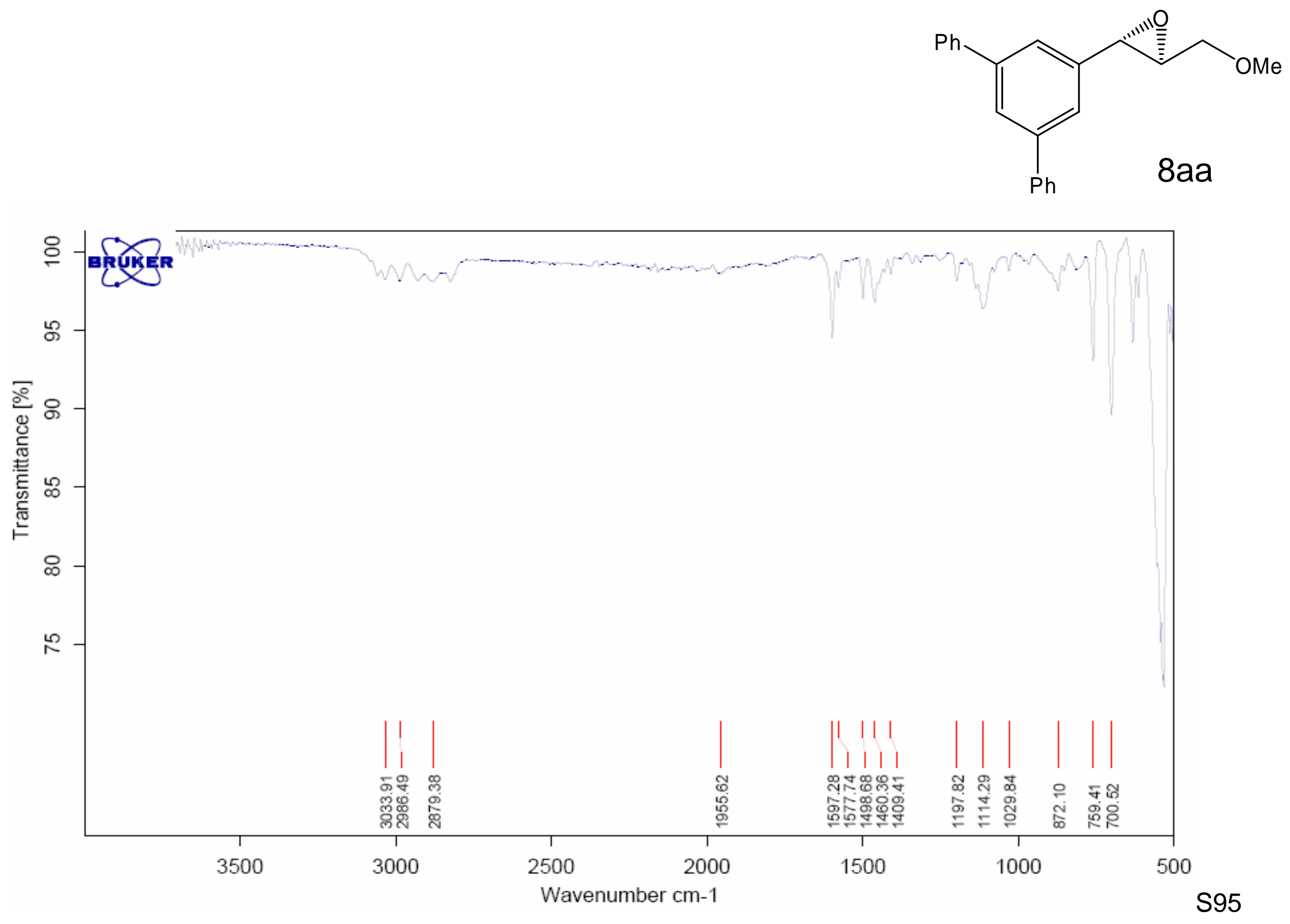


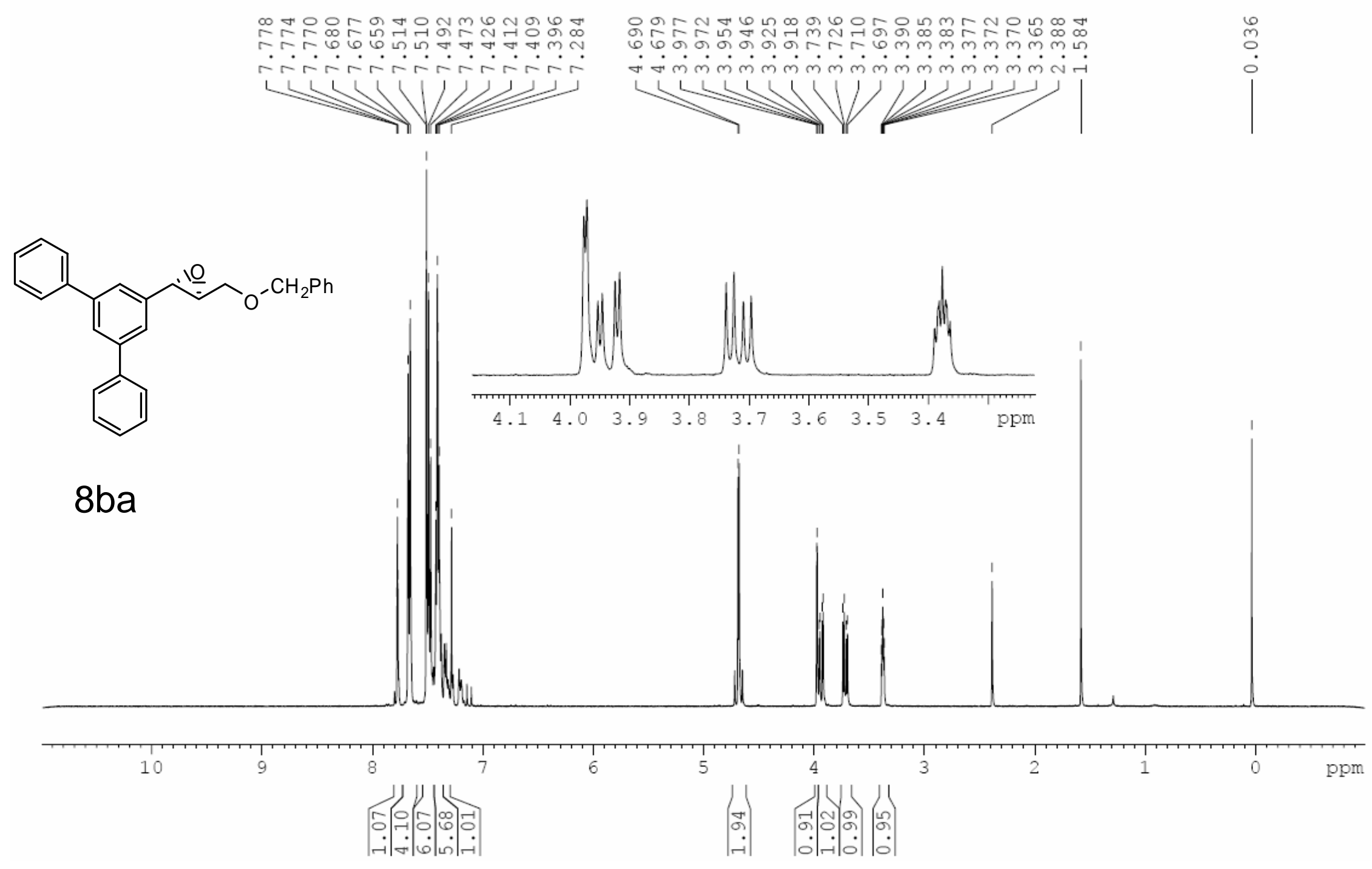




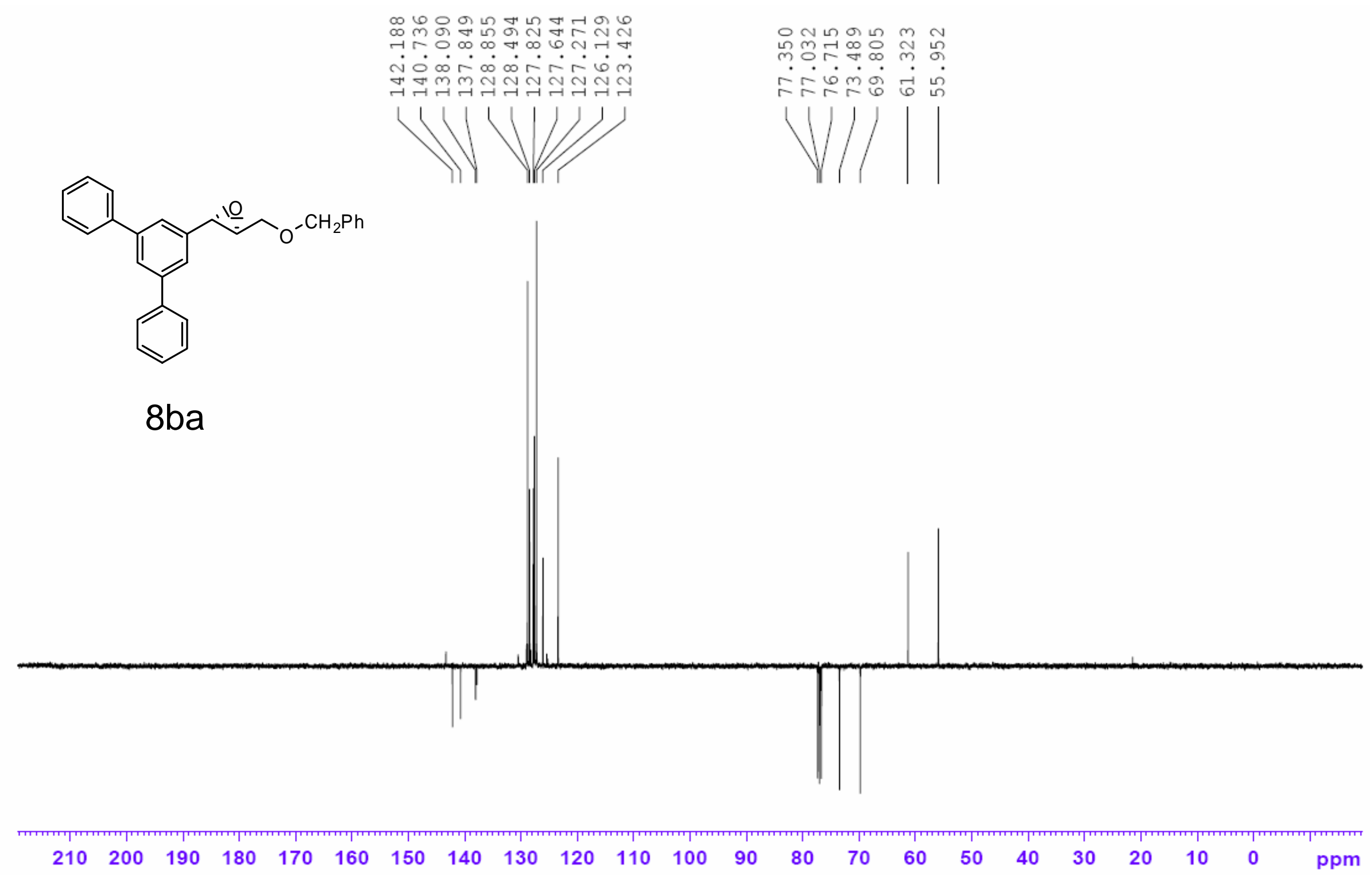




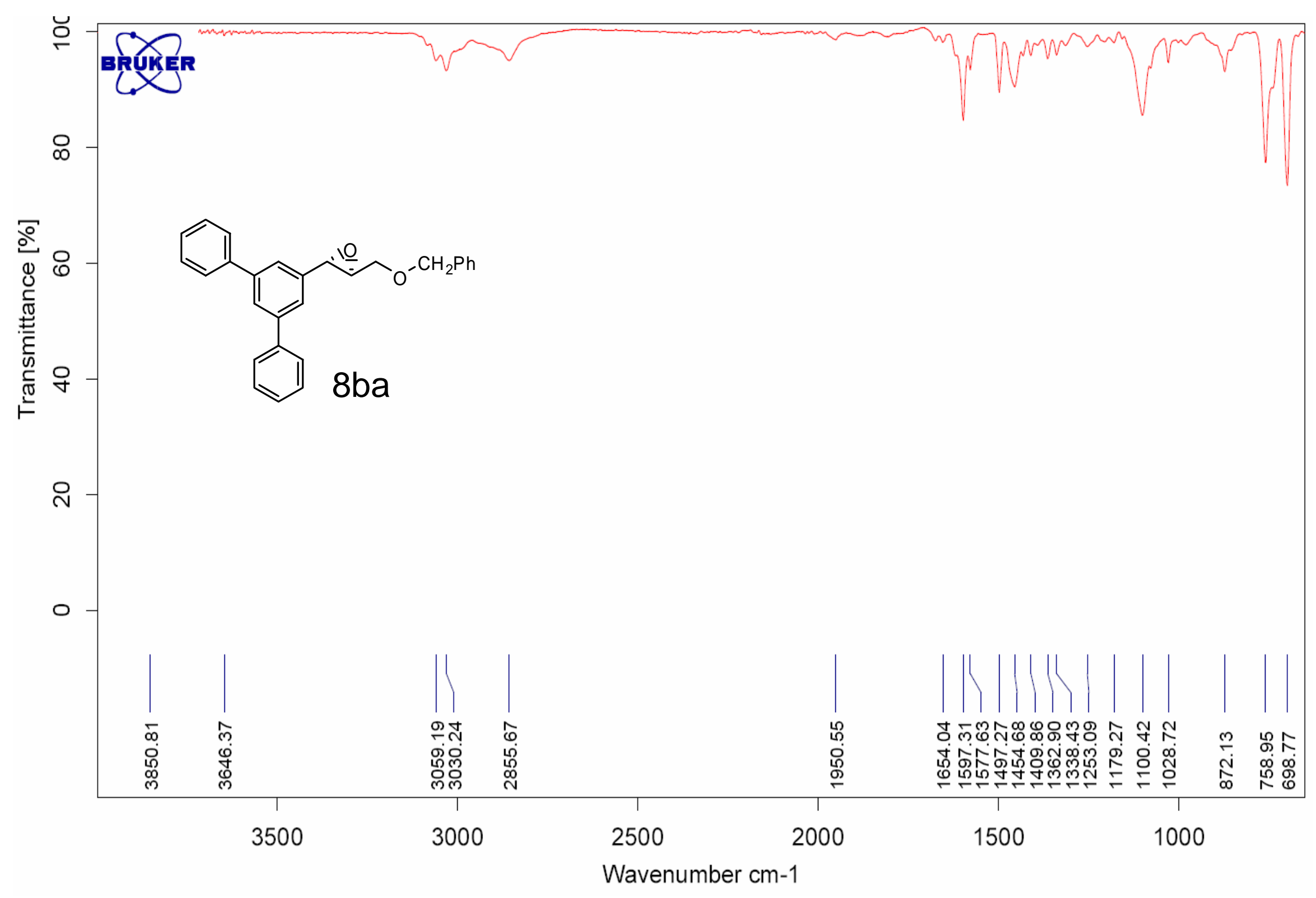




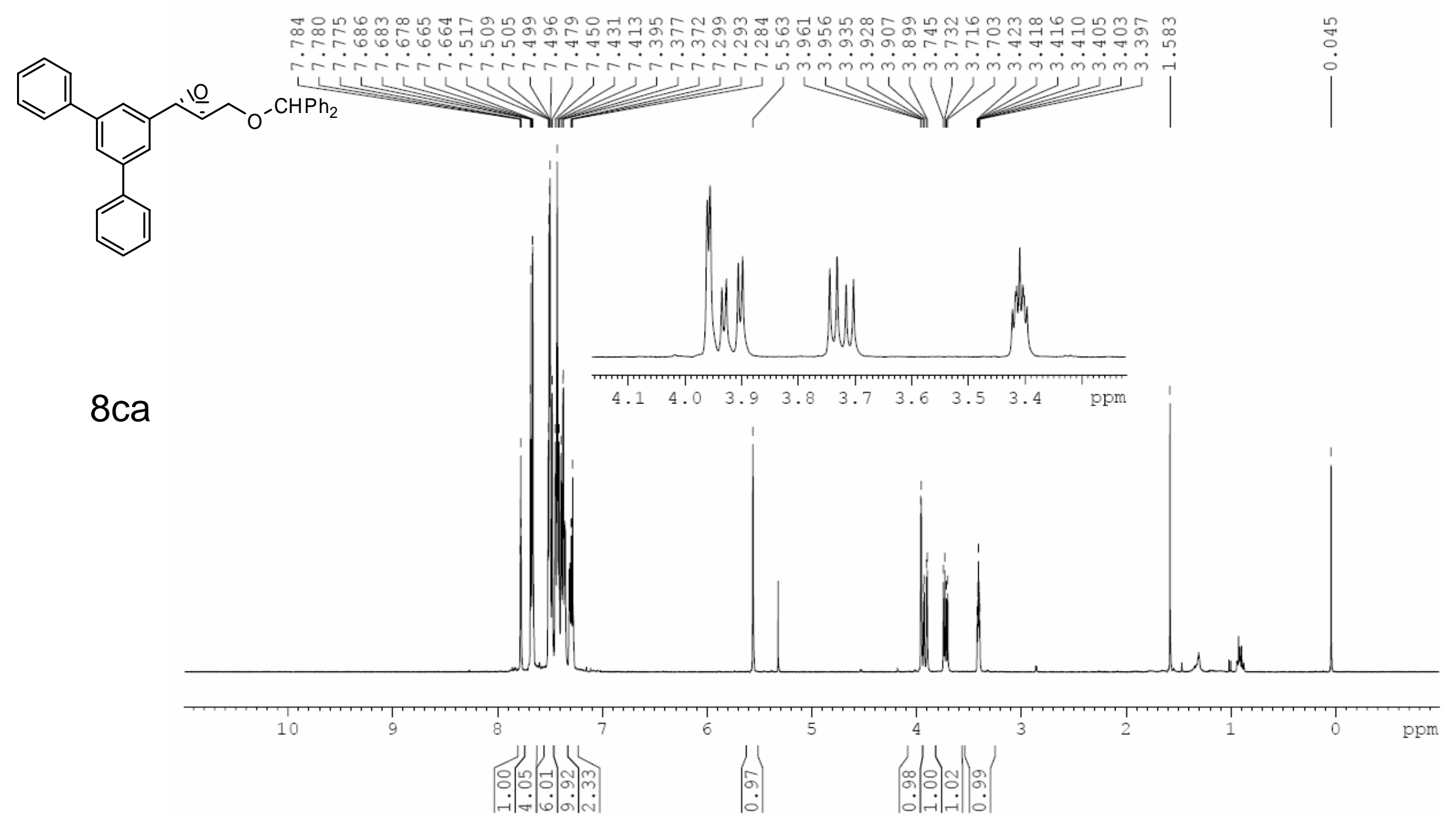




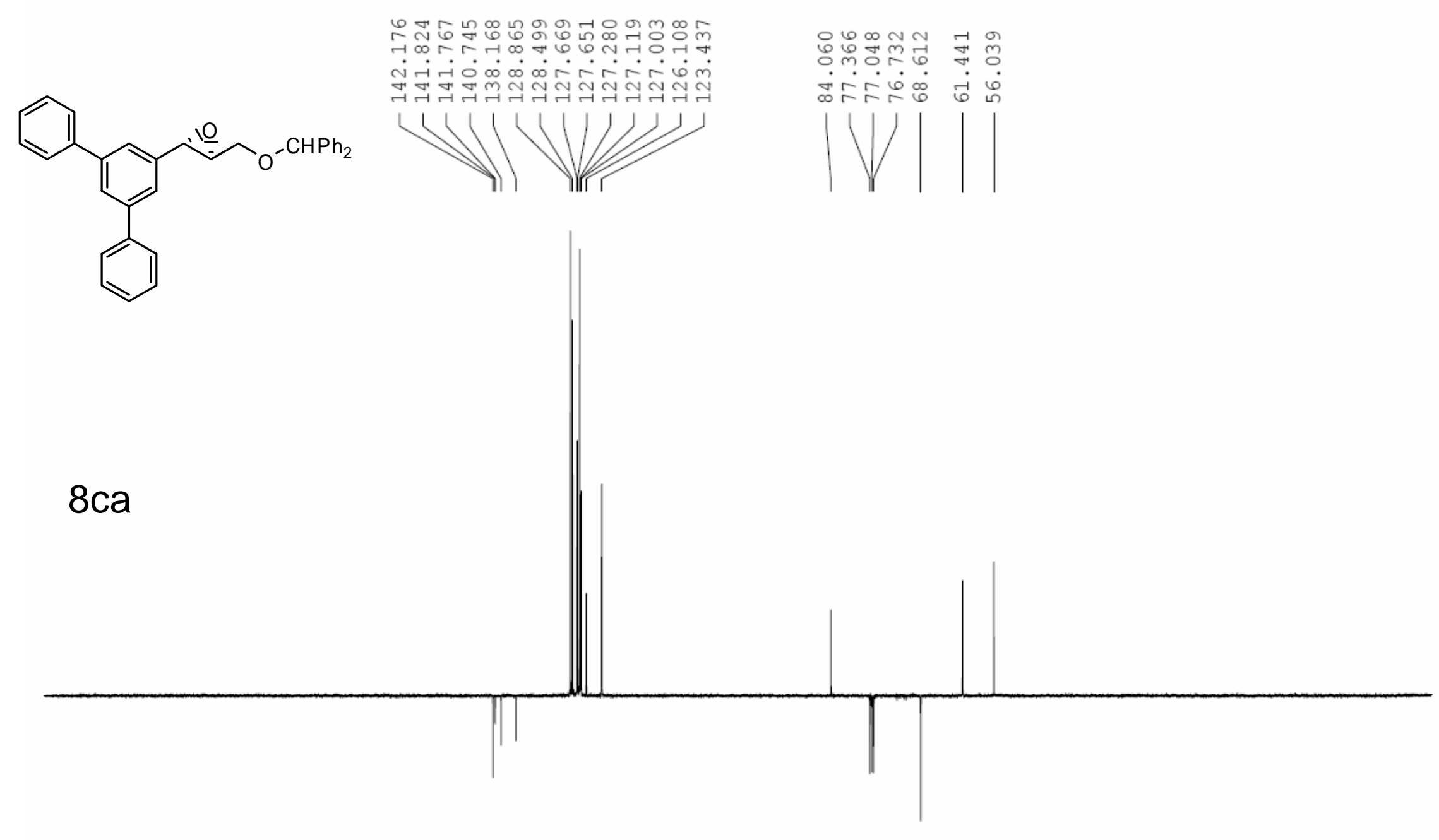

$\begin{array}{llllllllllllllllllllllllll}210 & 200 & 190 & 180 & 170 & 160 & 150 & 140 & 130 & 120 & 110 & 100 & 90 & 80 & 70 & 60 & 50 & 40 & 30 & 20 & 10 & 0 & \mathrm{ppm}\end{array}$ 


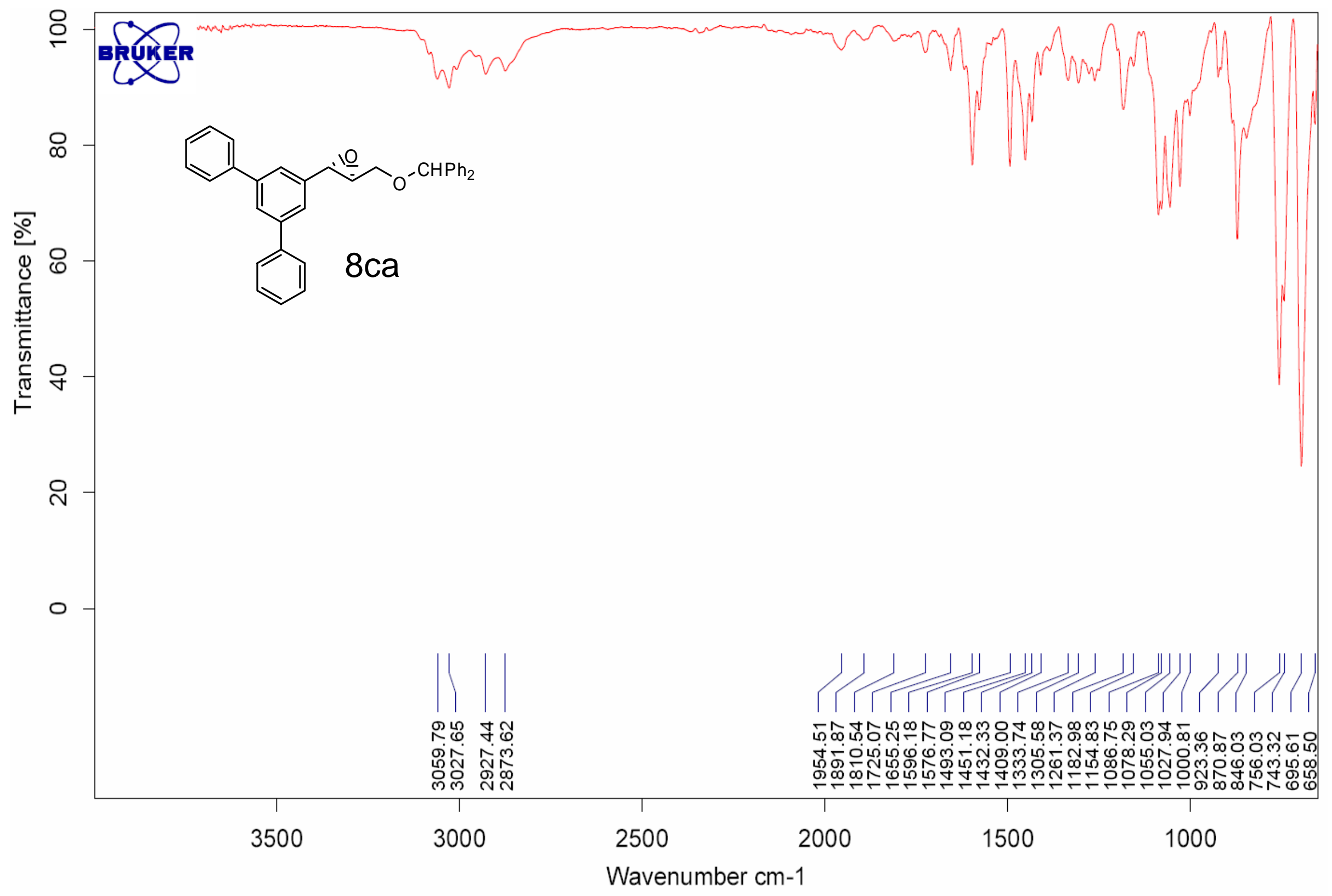

S101 


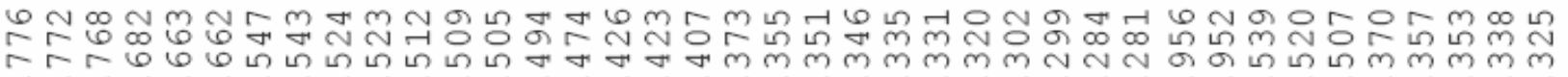

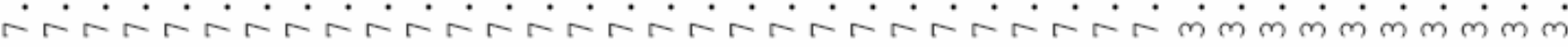

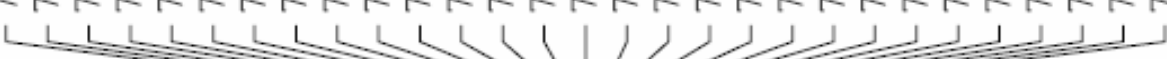

\section{า7 1 ini}

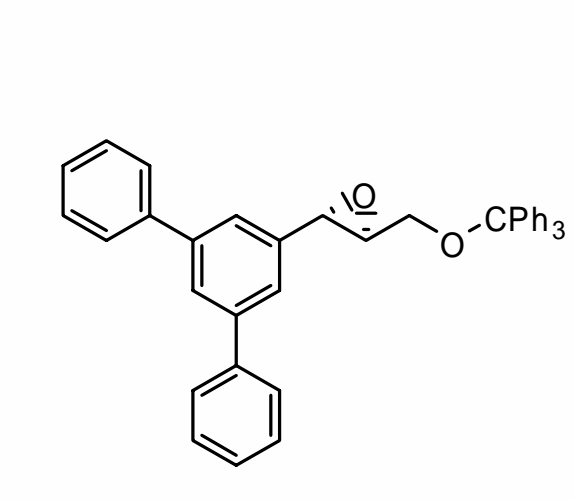

8da

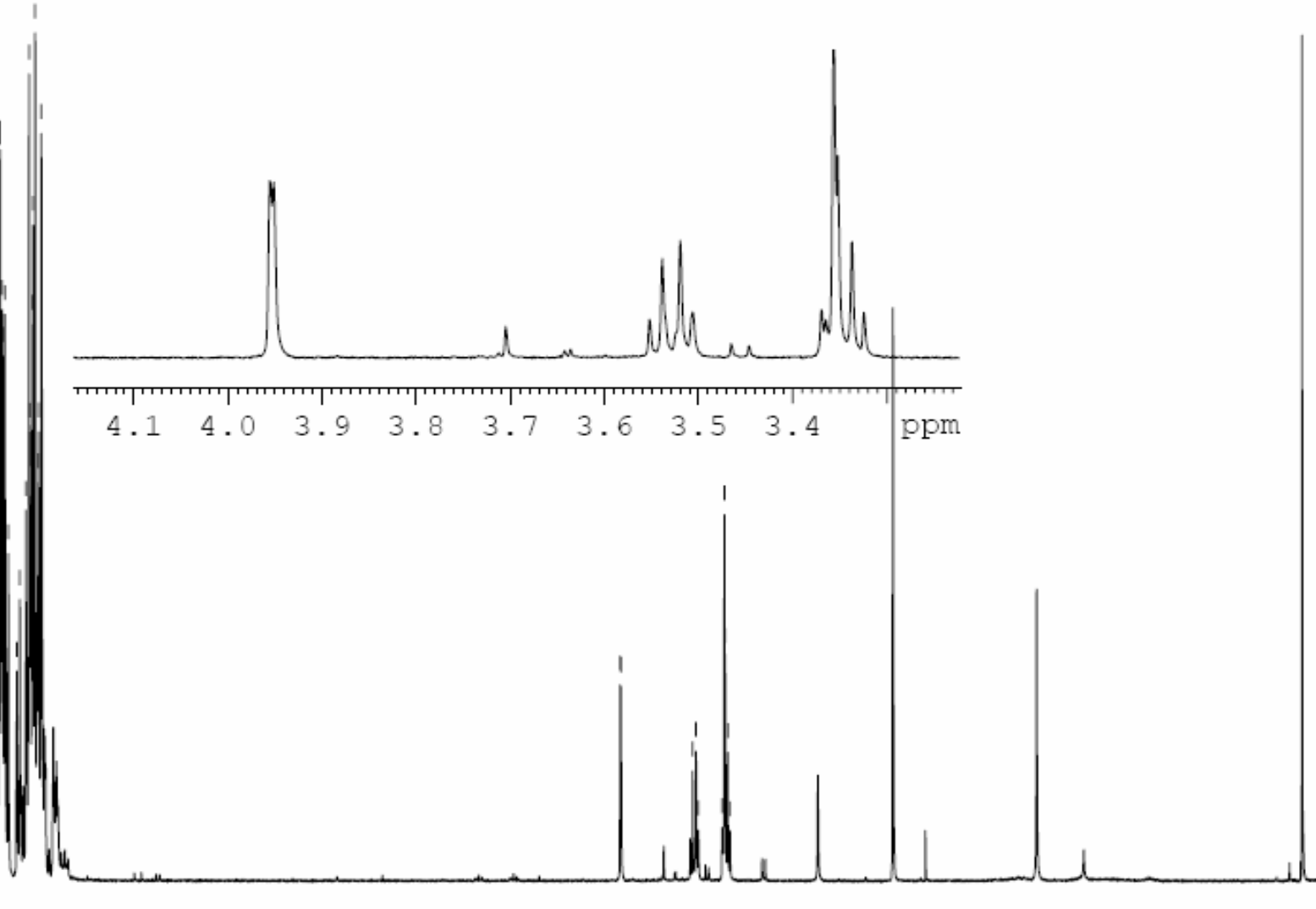

10

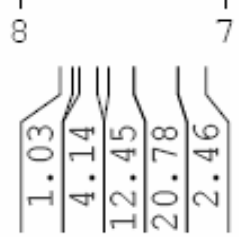

3

2

1

ppm 


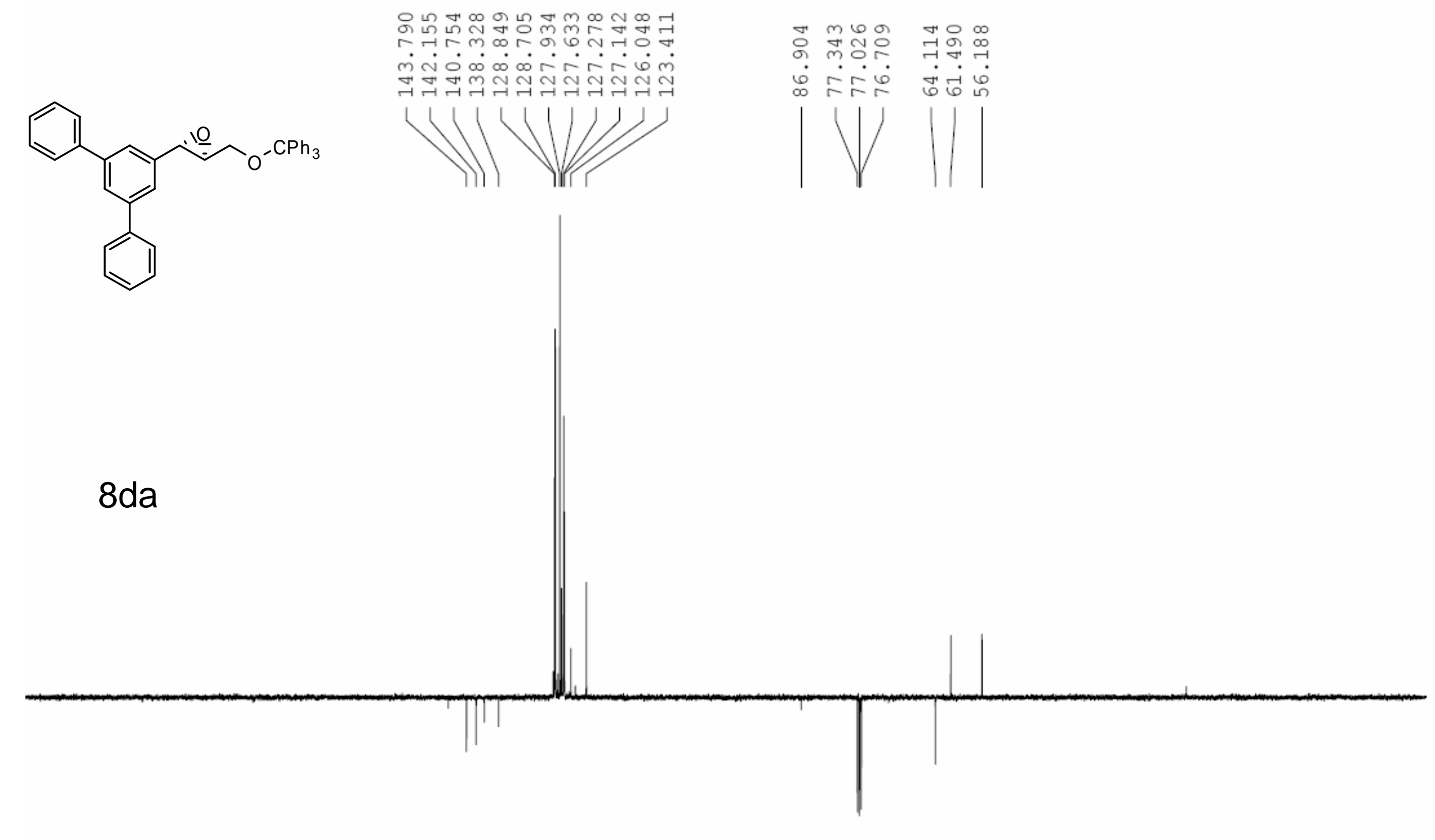

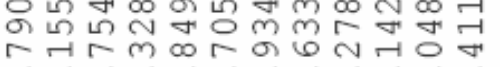
miom $\infty$ m n r n m

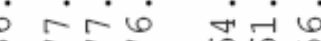

| 


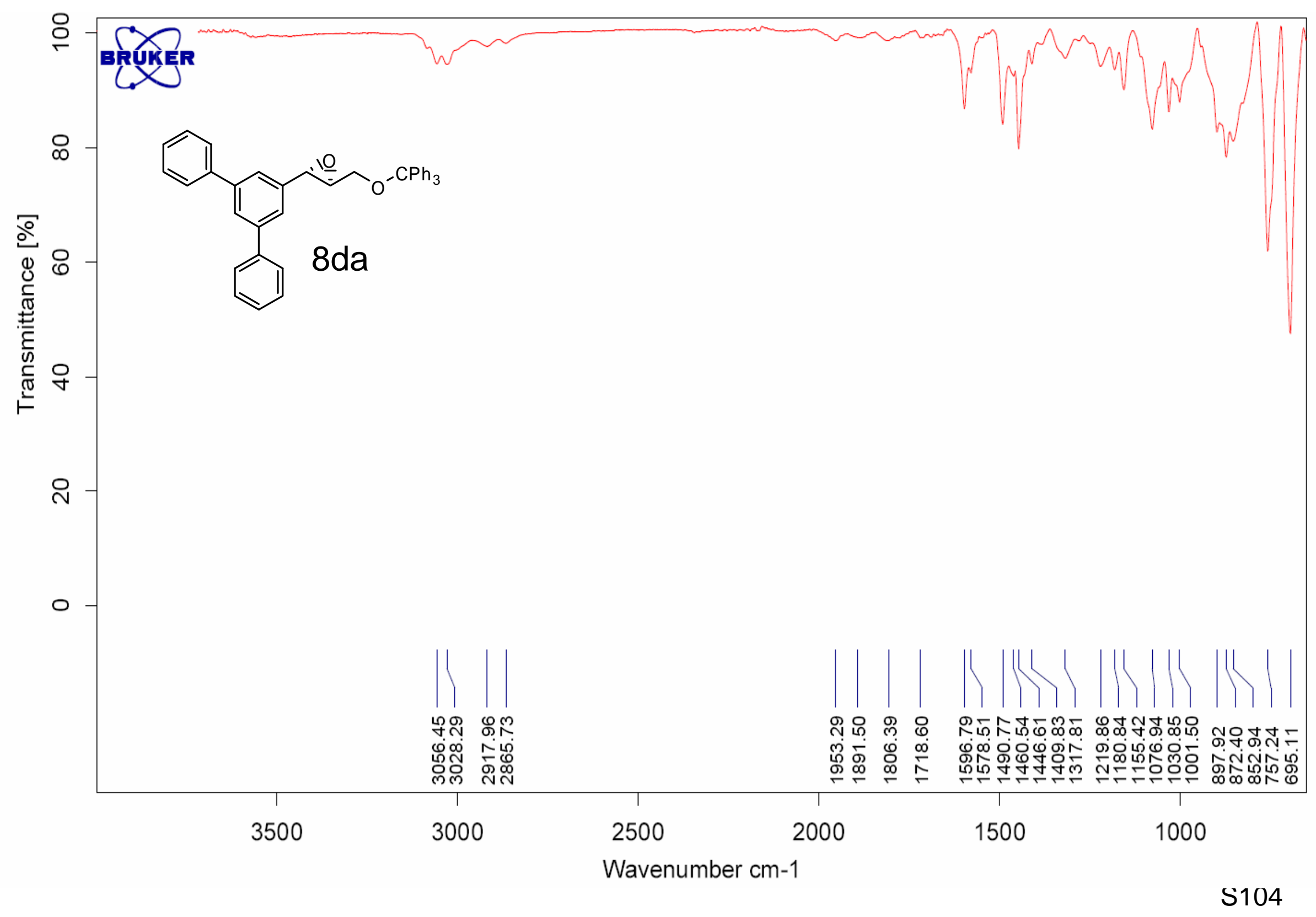




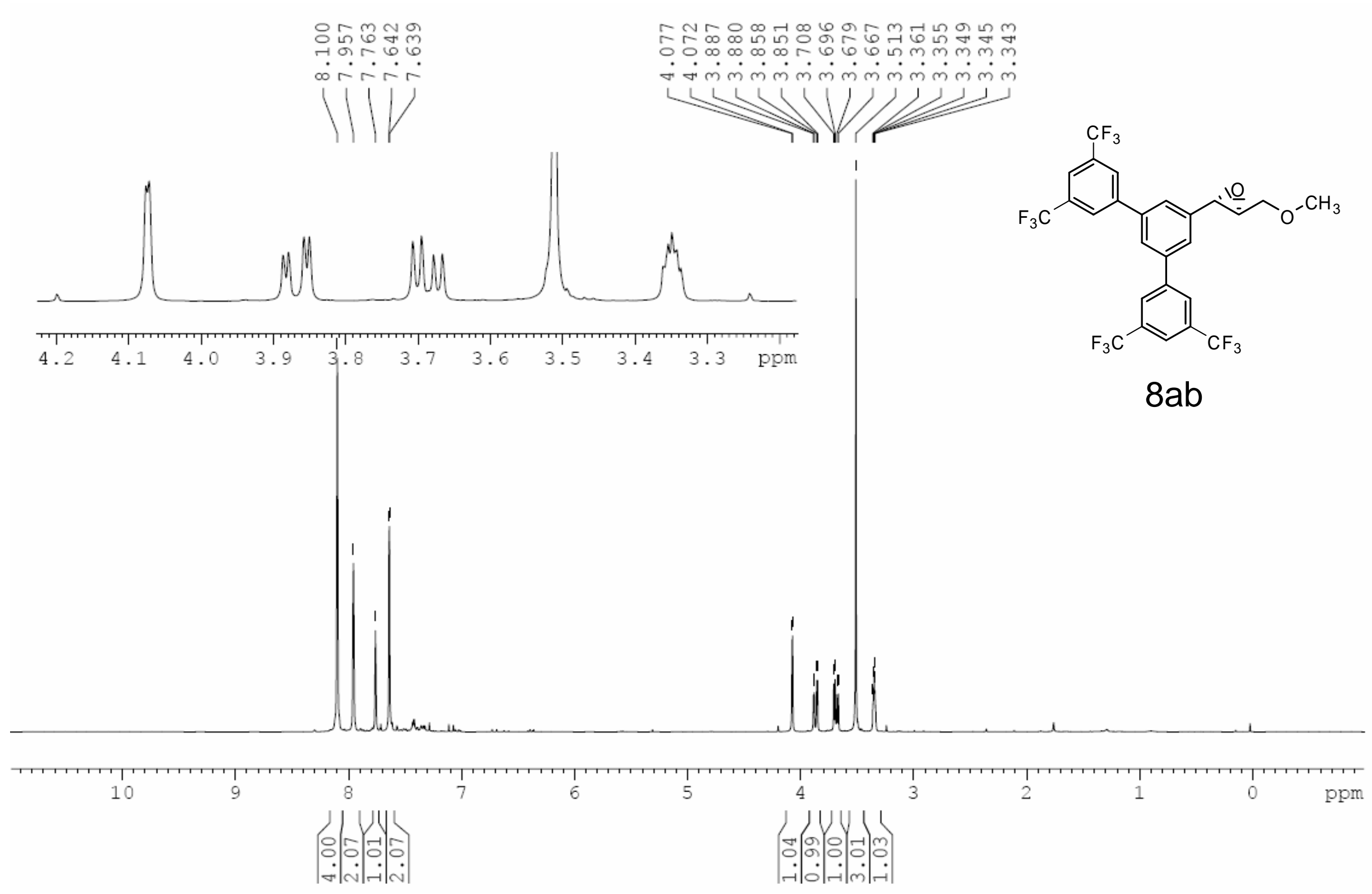

S105 


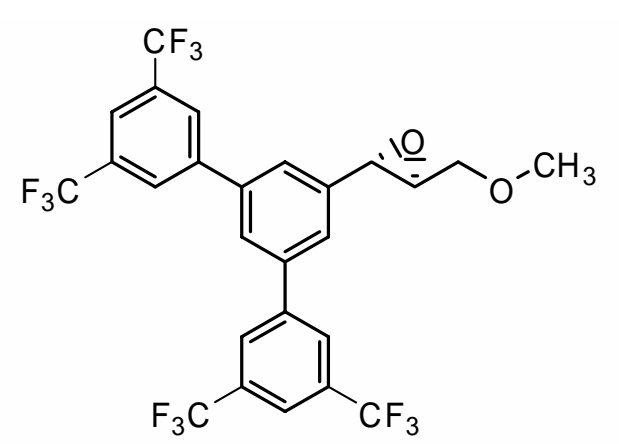

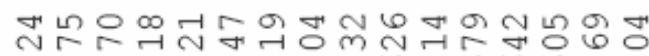

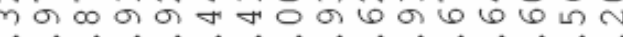

ขंबं 㟧

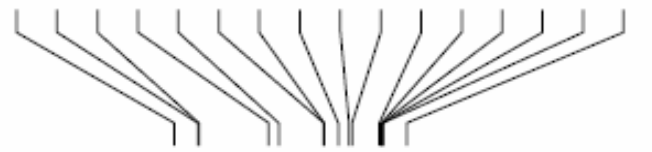

$8 a b$

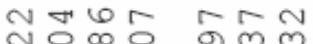

m...

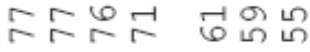

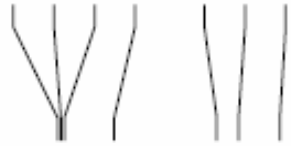

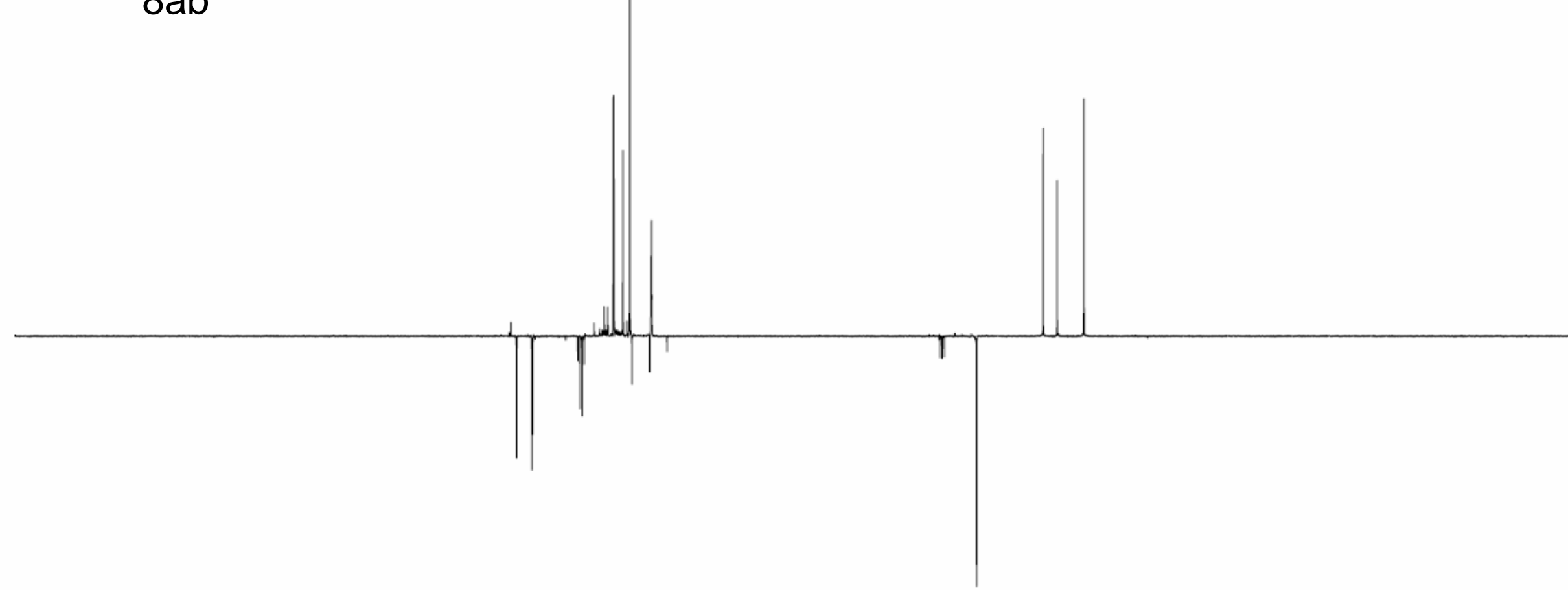

$\begin{array}{llllllllllllllllllllll}210 & 200 & 190 & 180 & 170 & 160 & 150 & 140 & 130 & 120 & 110 & 100 & 90 & 80 & 70 & 60 & 50 & 40 & 30 & 20 & 10 & 0\end{array}$ 


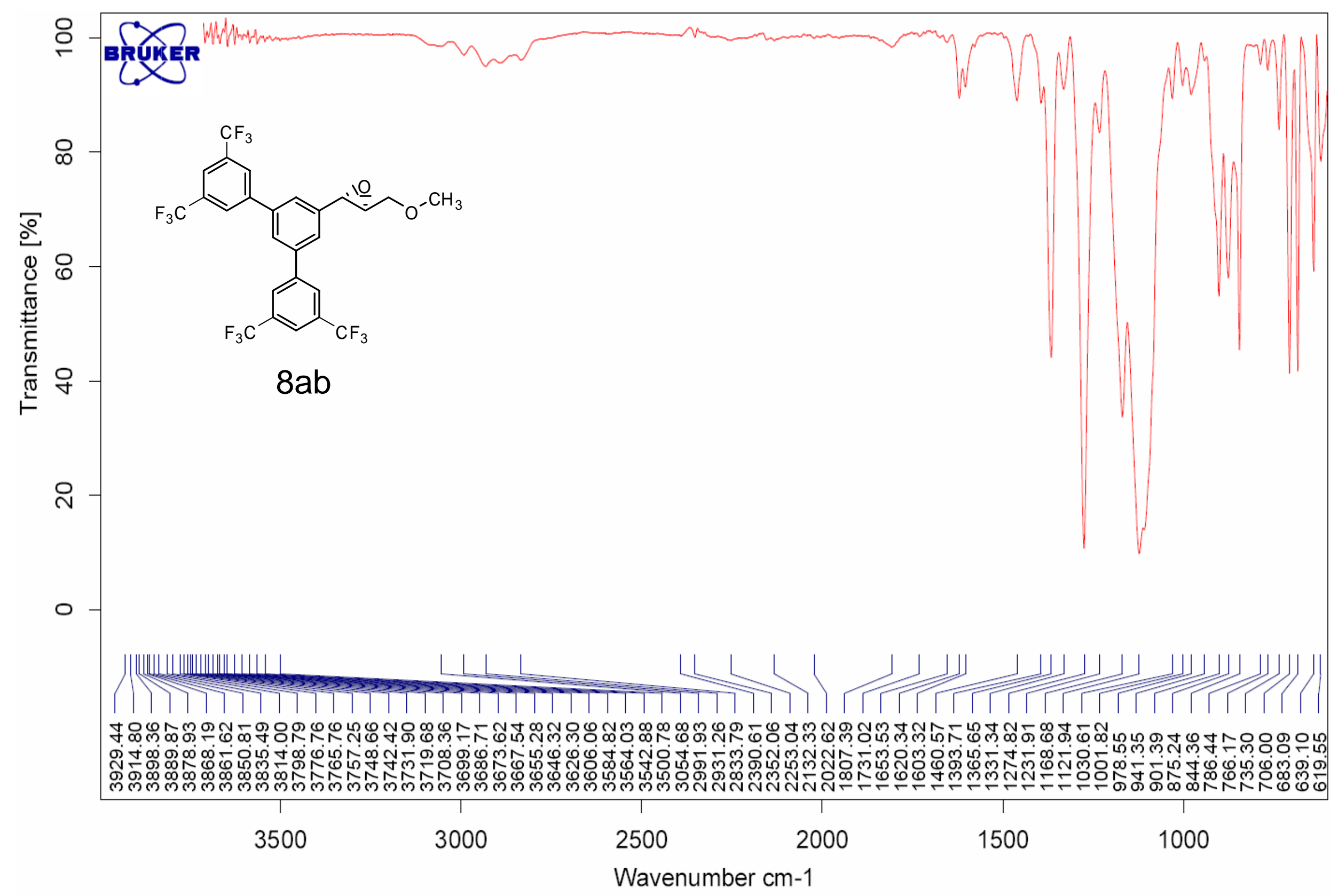



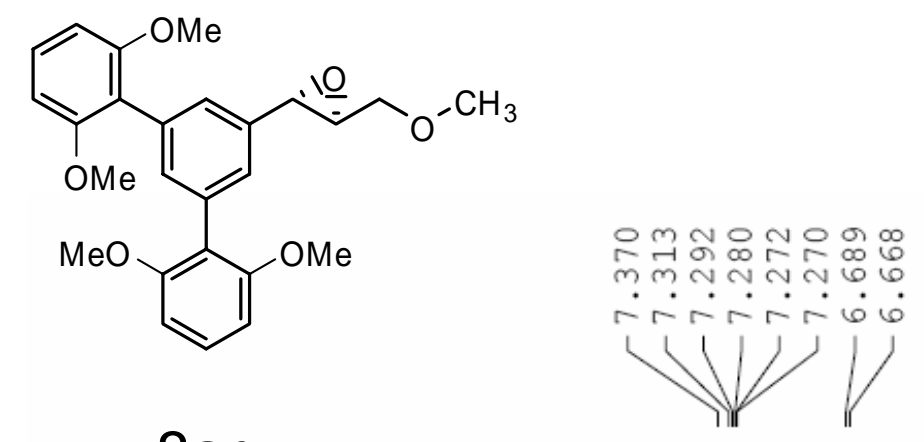

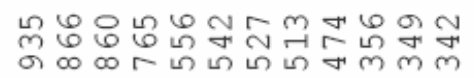

$\dot{m} \dot{m} \dot{m} \dot{m} \dot{m} \dot{m} \dot{m} \dot{m}$

$8 a g$
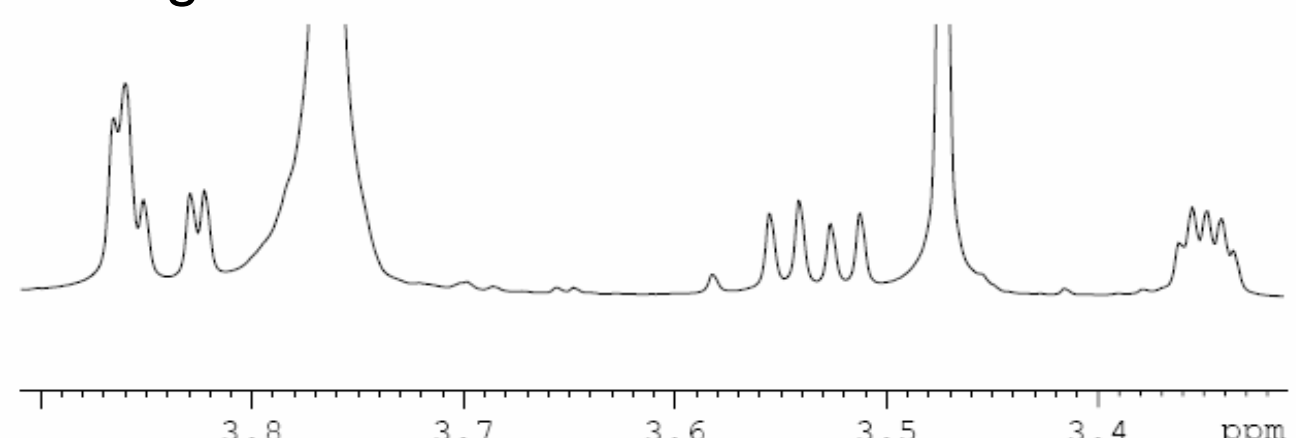

3. 8

3.7

3.6

3.5
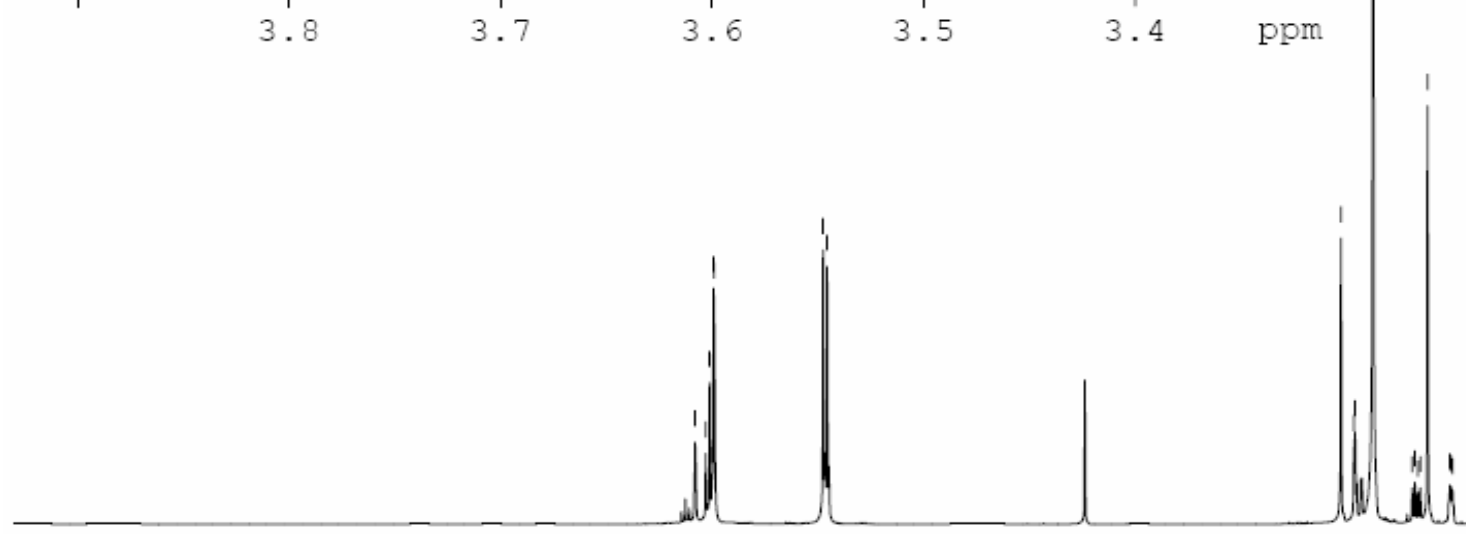

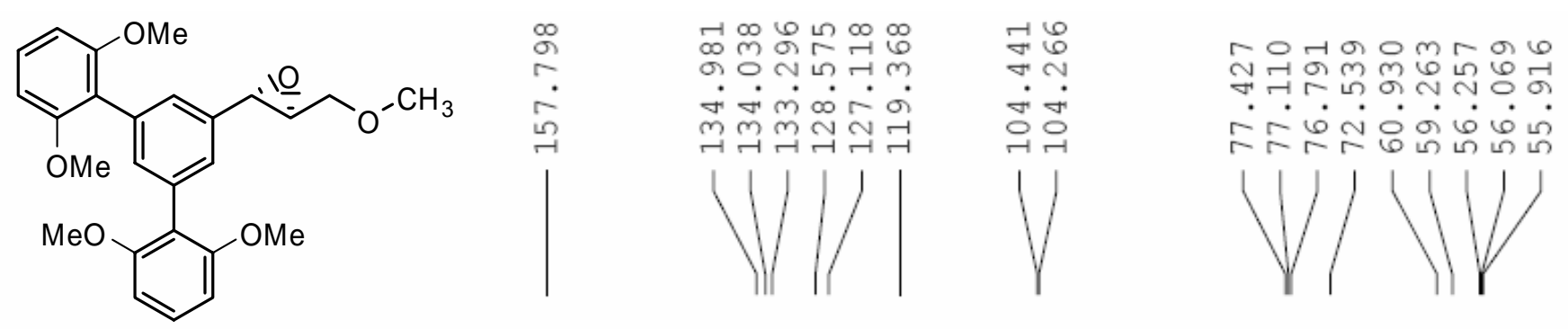

$8 \mathrm{ag}$

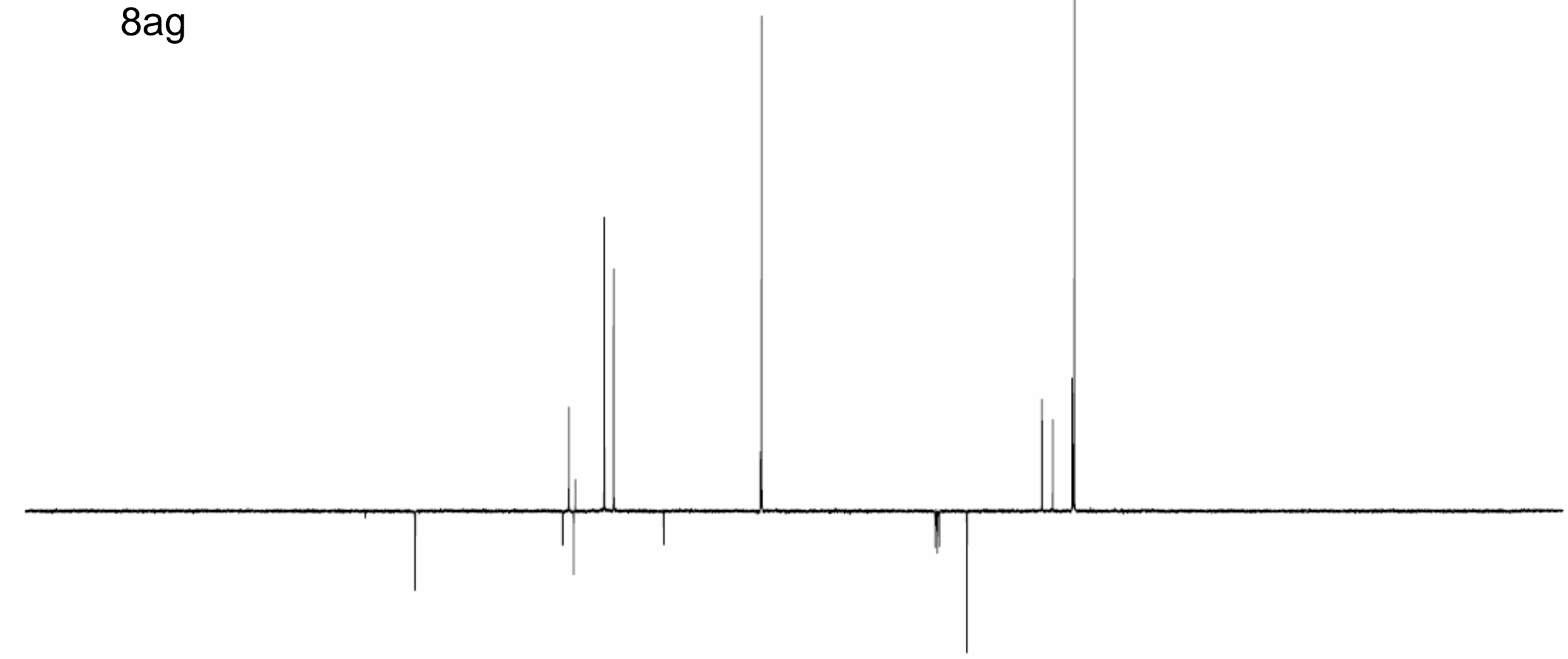

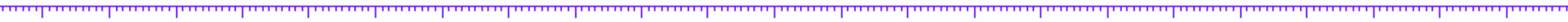

$\begin{array}{llllllllllllllllllllllll}210 & 200 & 190 & 180 & 170 & 160 & 150 & 140 & 130 & 120 & 110 & 100 & 90 & 80 & 70 & 60 & 50 & 40 & 30 & 20 & 10 & 0 & \text { ppm }\end{array}$ 


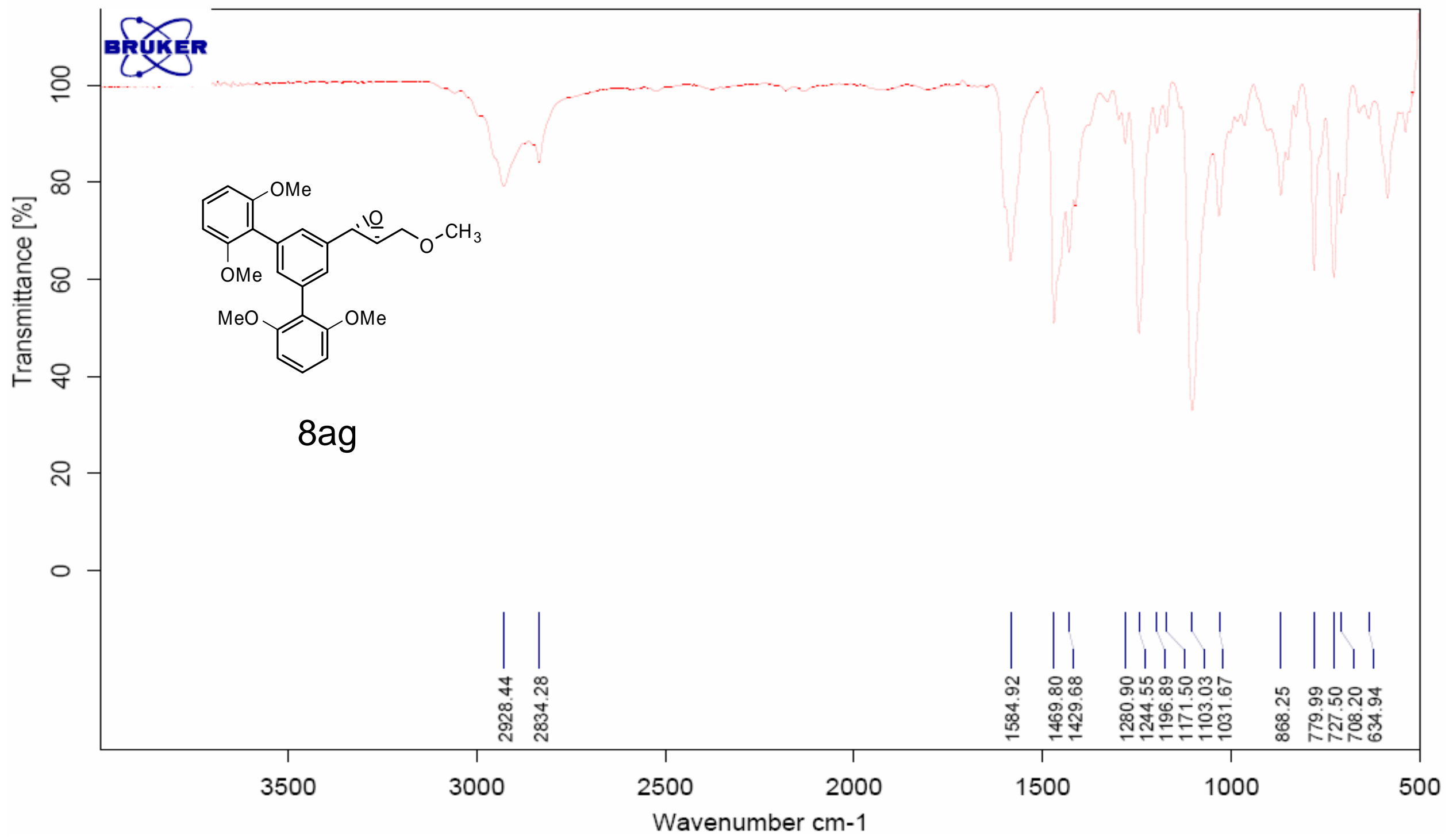

S110 


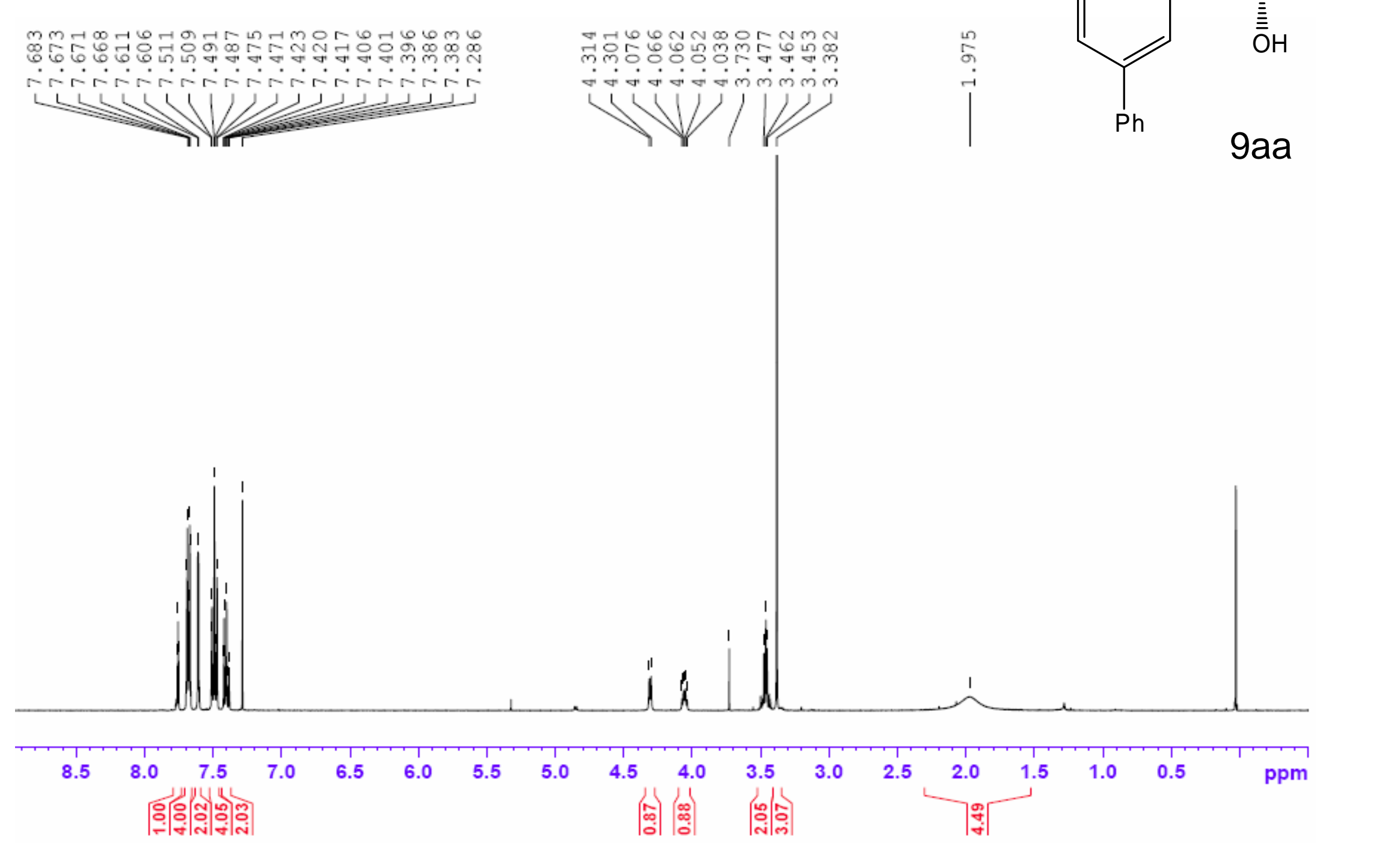




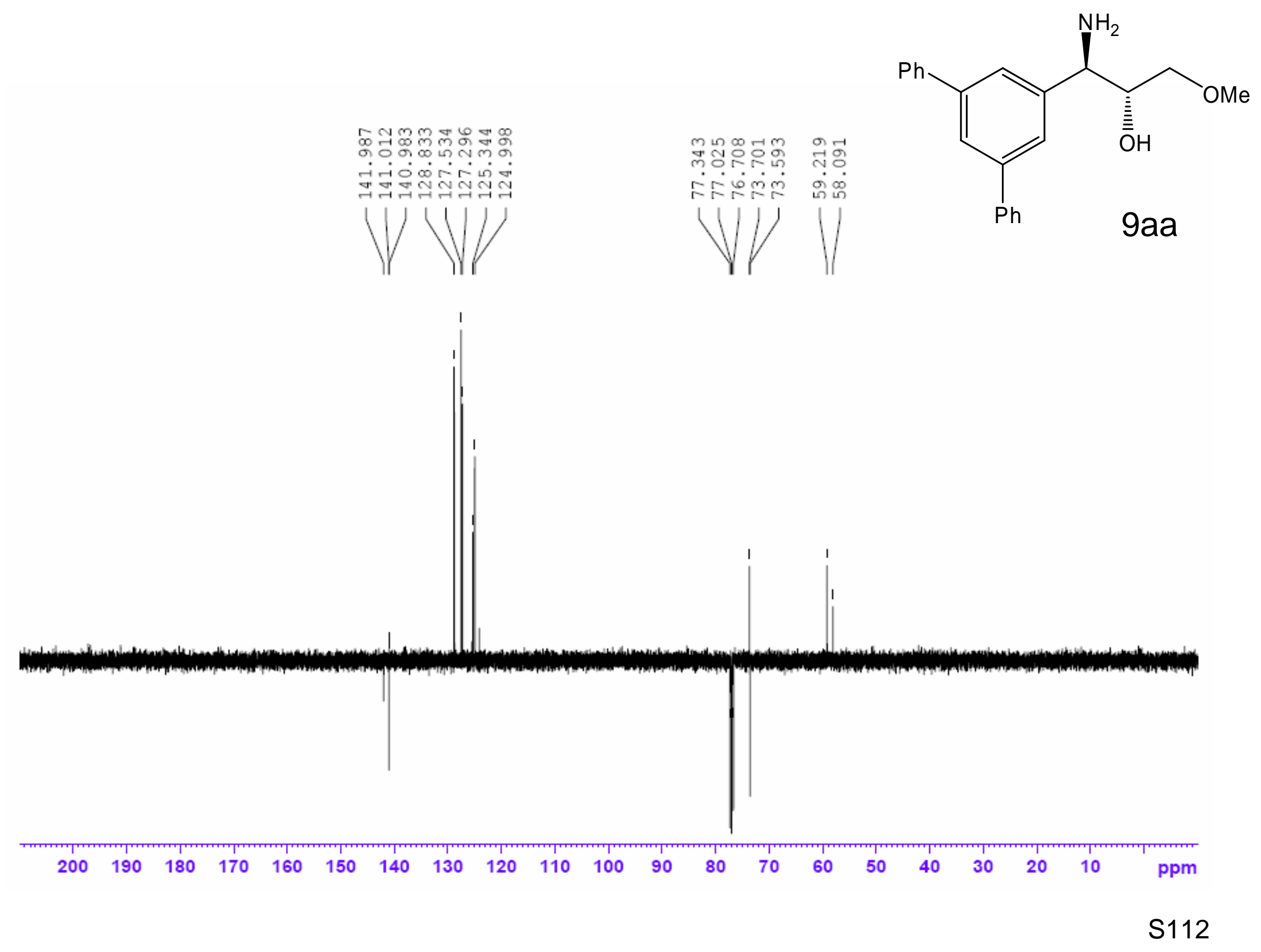



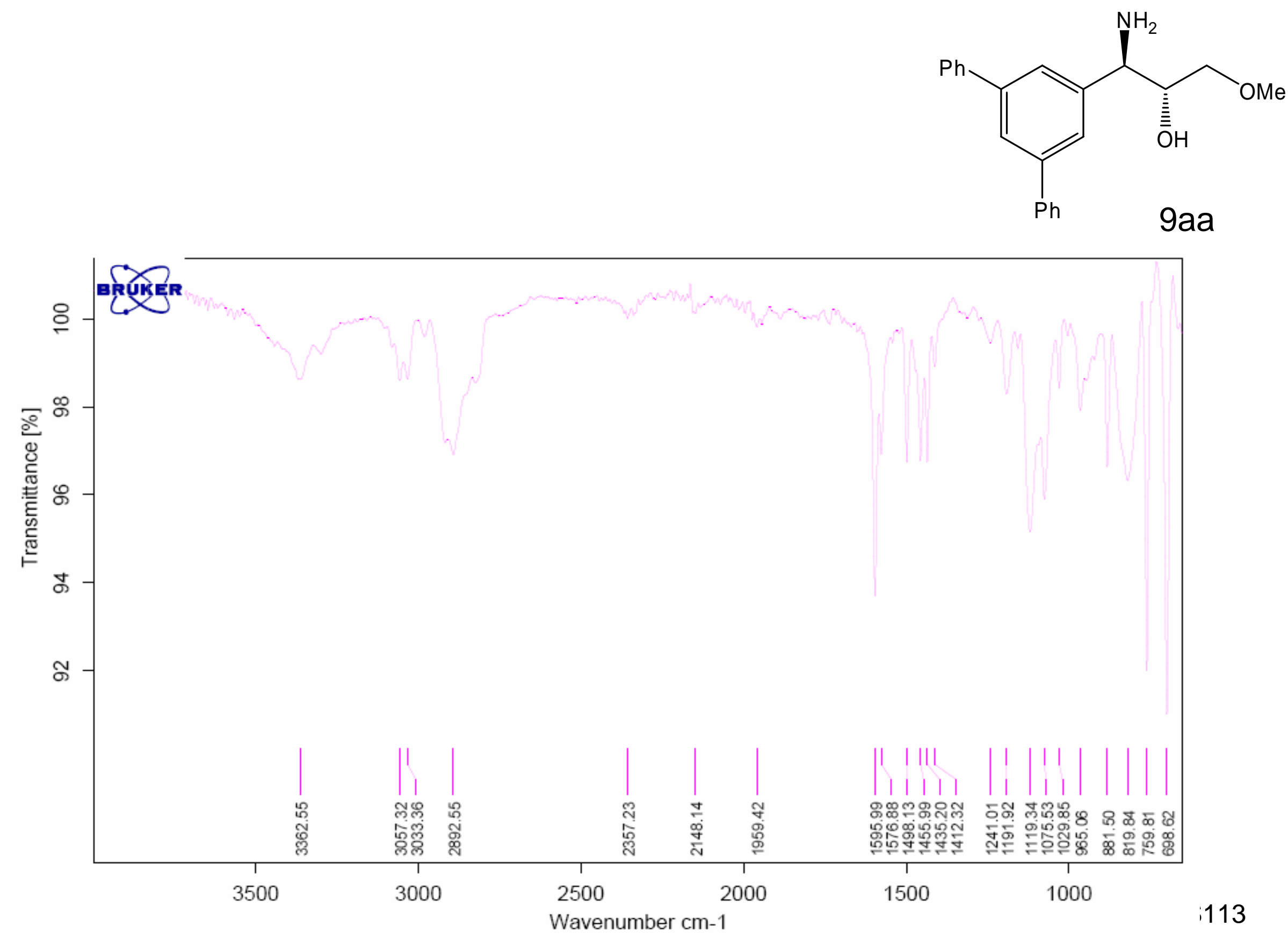


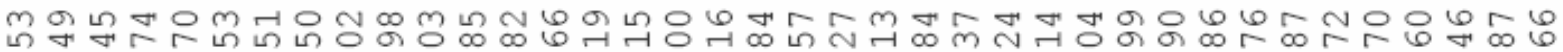

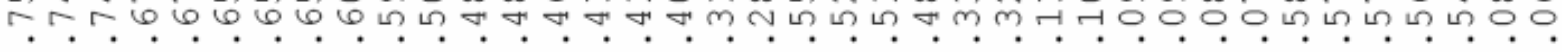

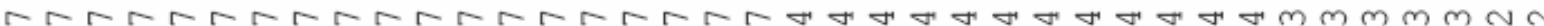

$\ldots$

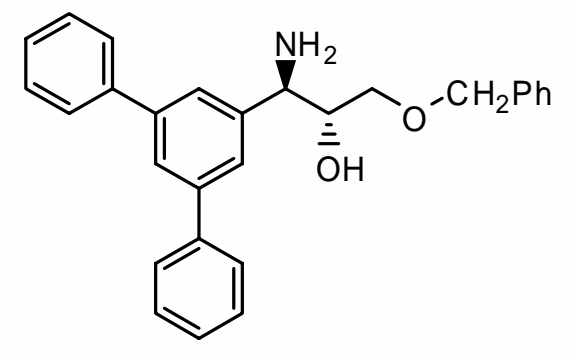

$9 \mathrm{ba}$
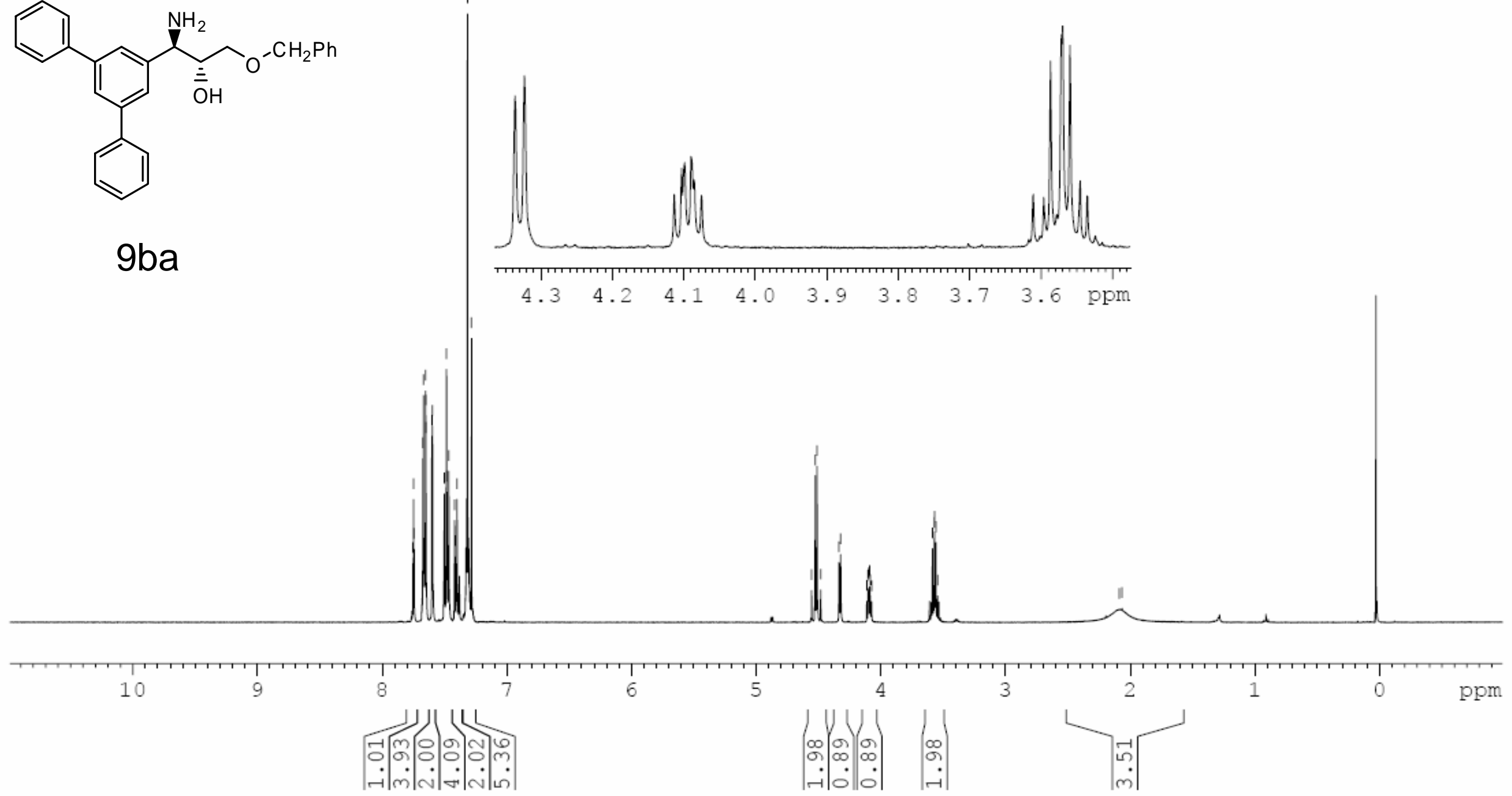

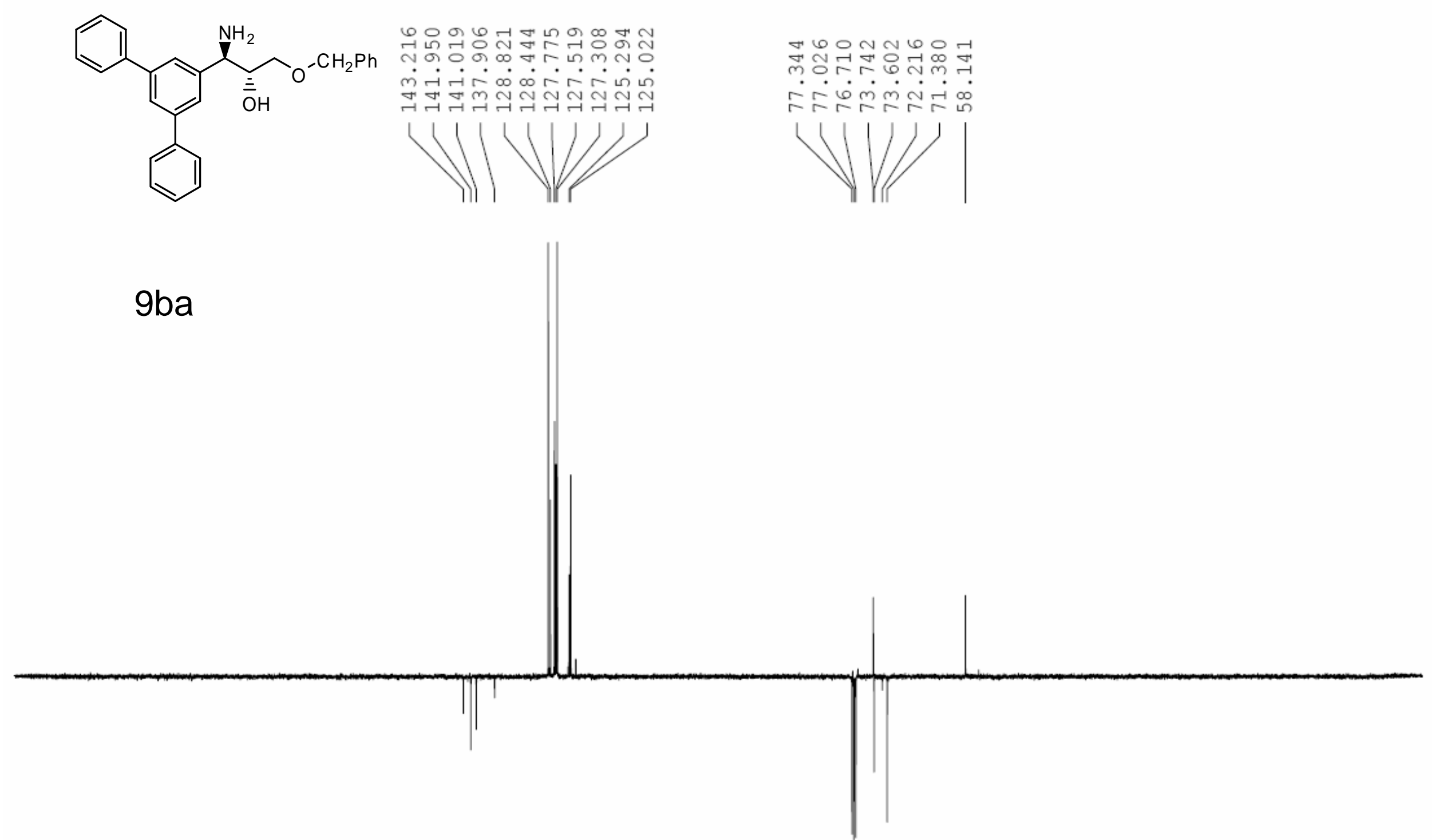

$\begin{array}{rlllllllllllllllllllllll}210 & 200 & 190 & 180 & 170 & 160 & 150 & 140 & 130 & 120 & 110 & 100 & 90 & 80 & 70 & 60 & 50 & 40 & 30 & 20 & 10 & 0 & \mathrm{ppm}\end{array}$




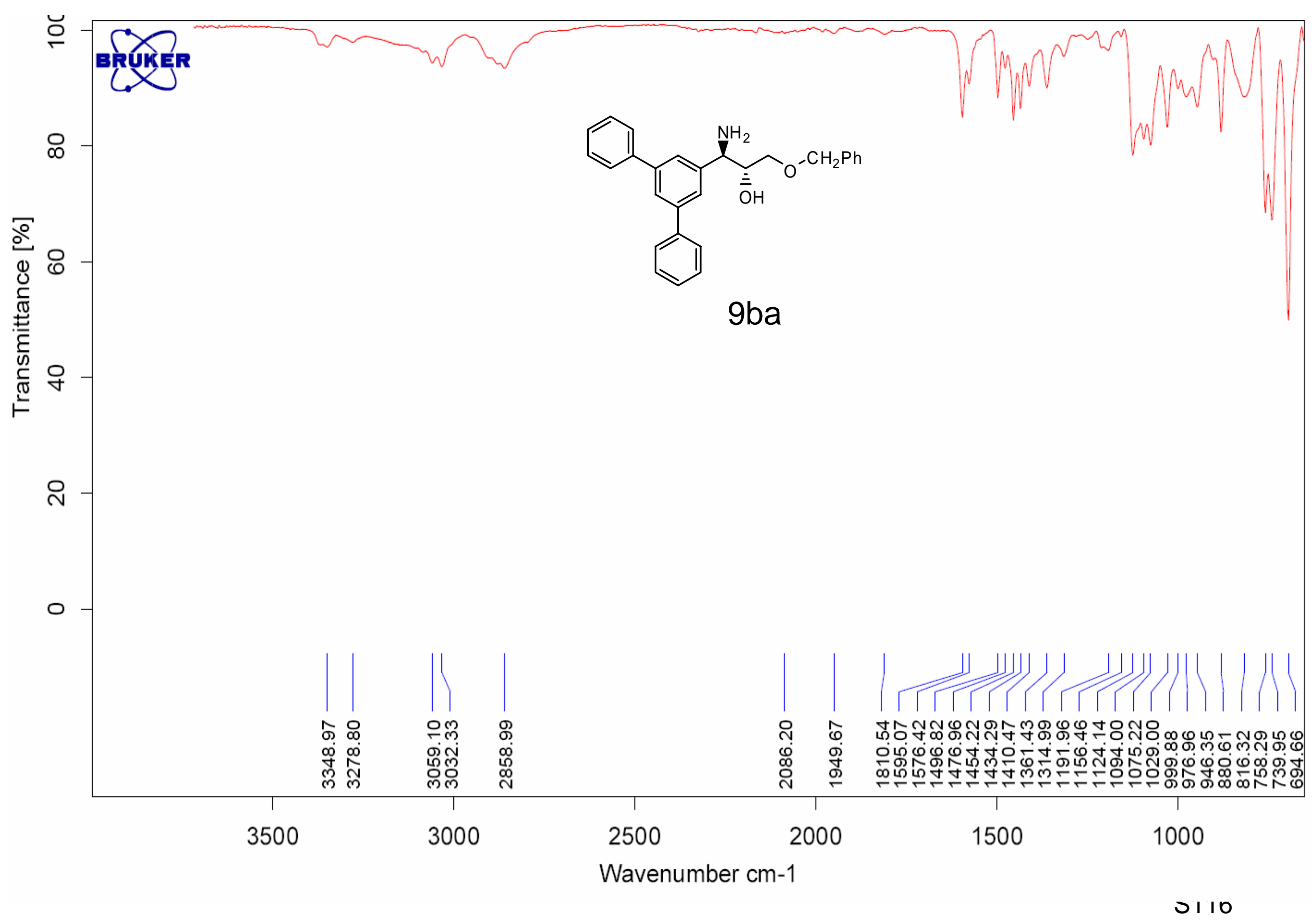




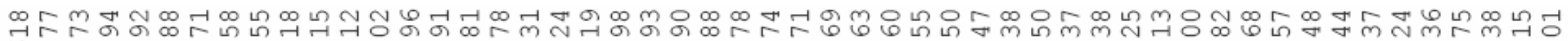
e.

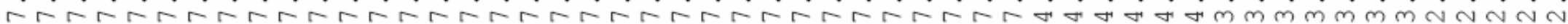

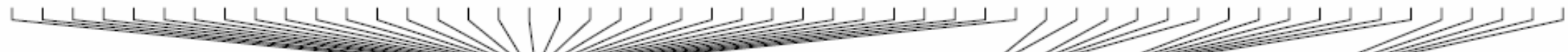

intin
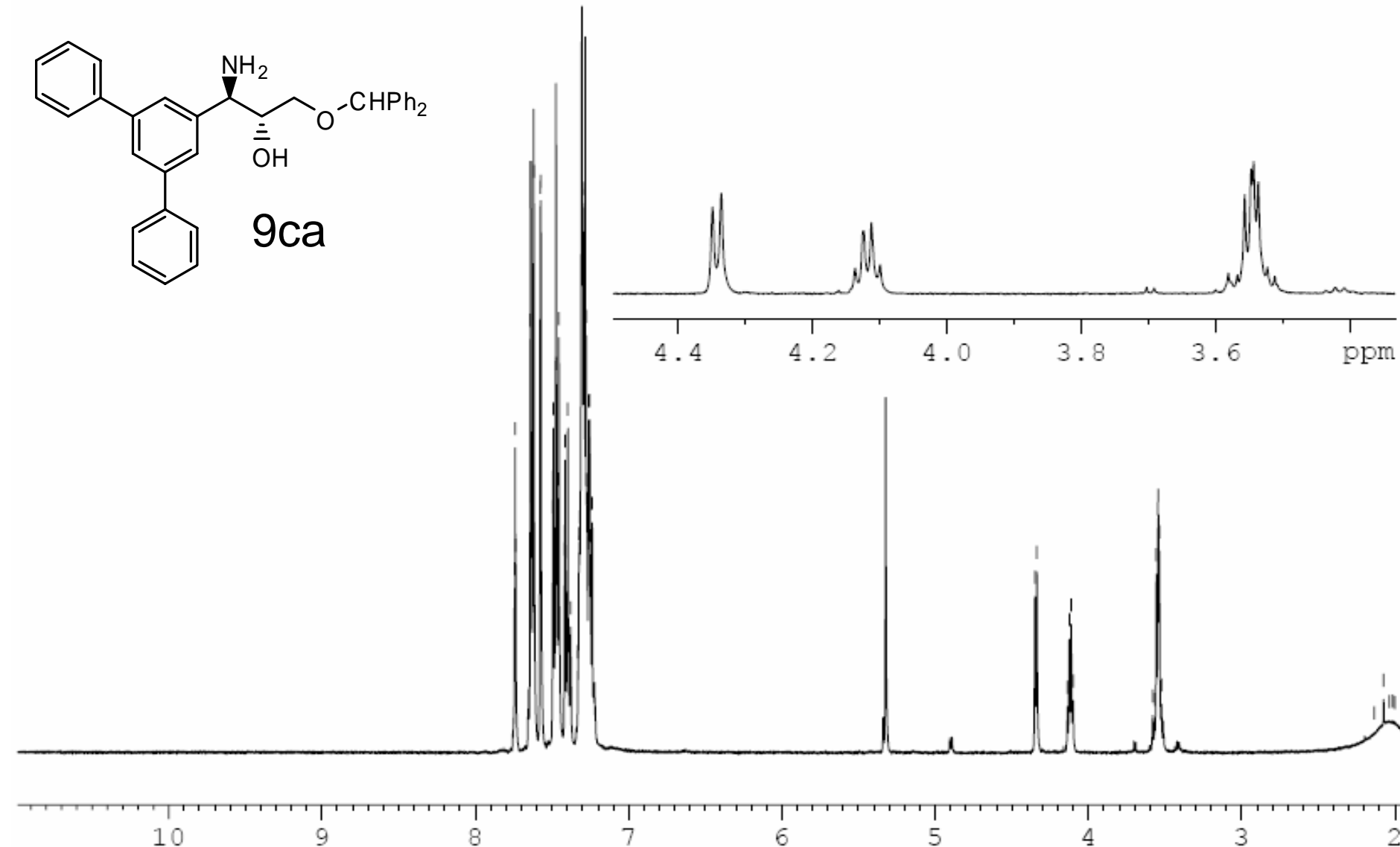

9

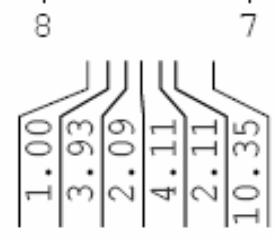

6

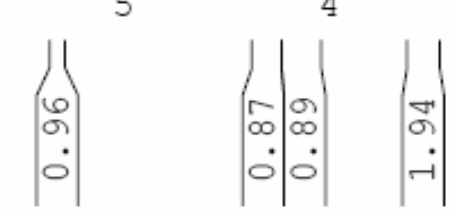

3

2

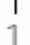

ppm 


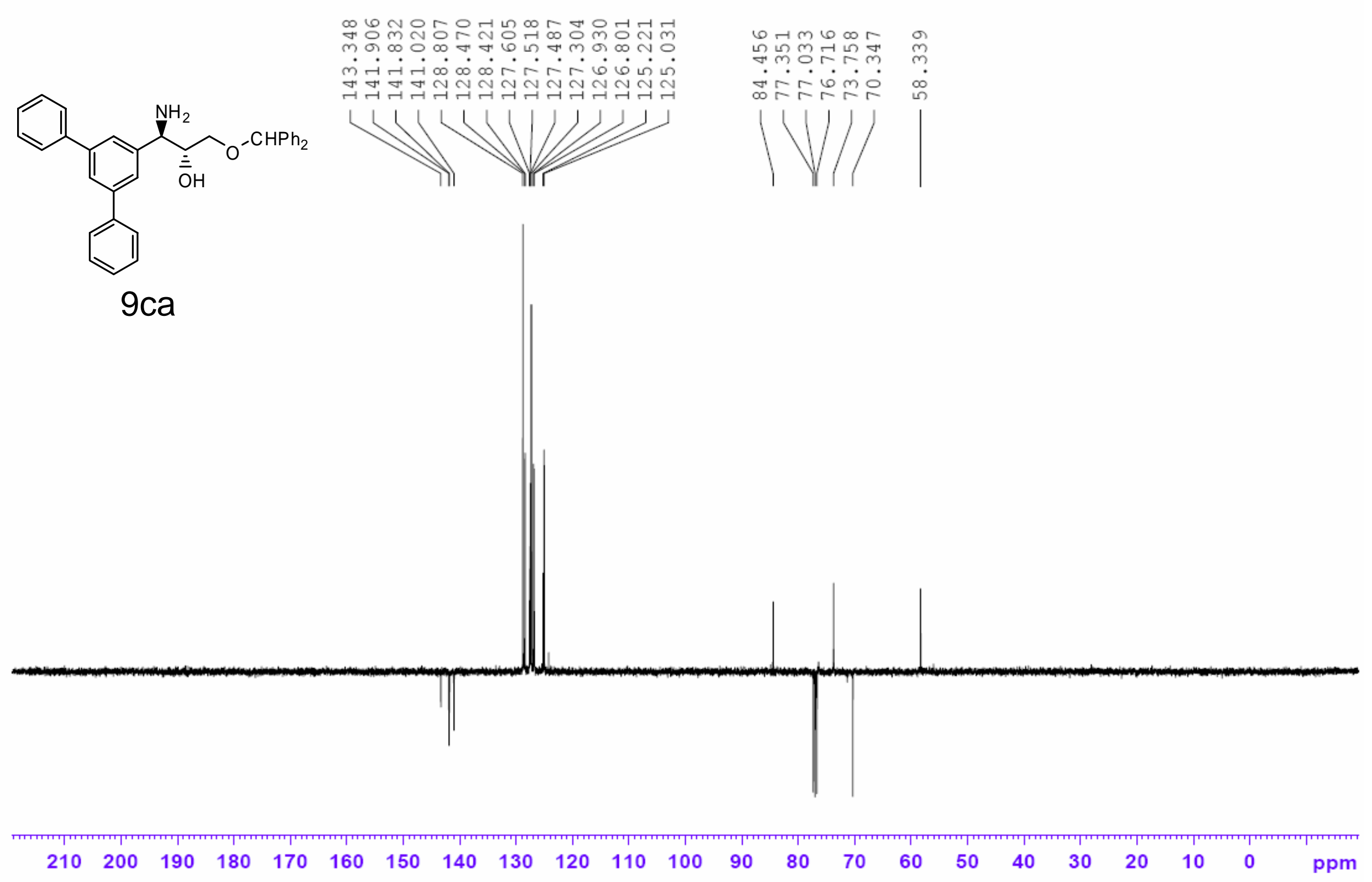




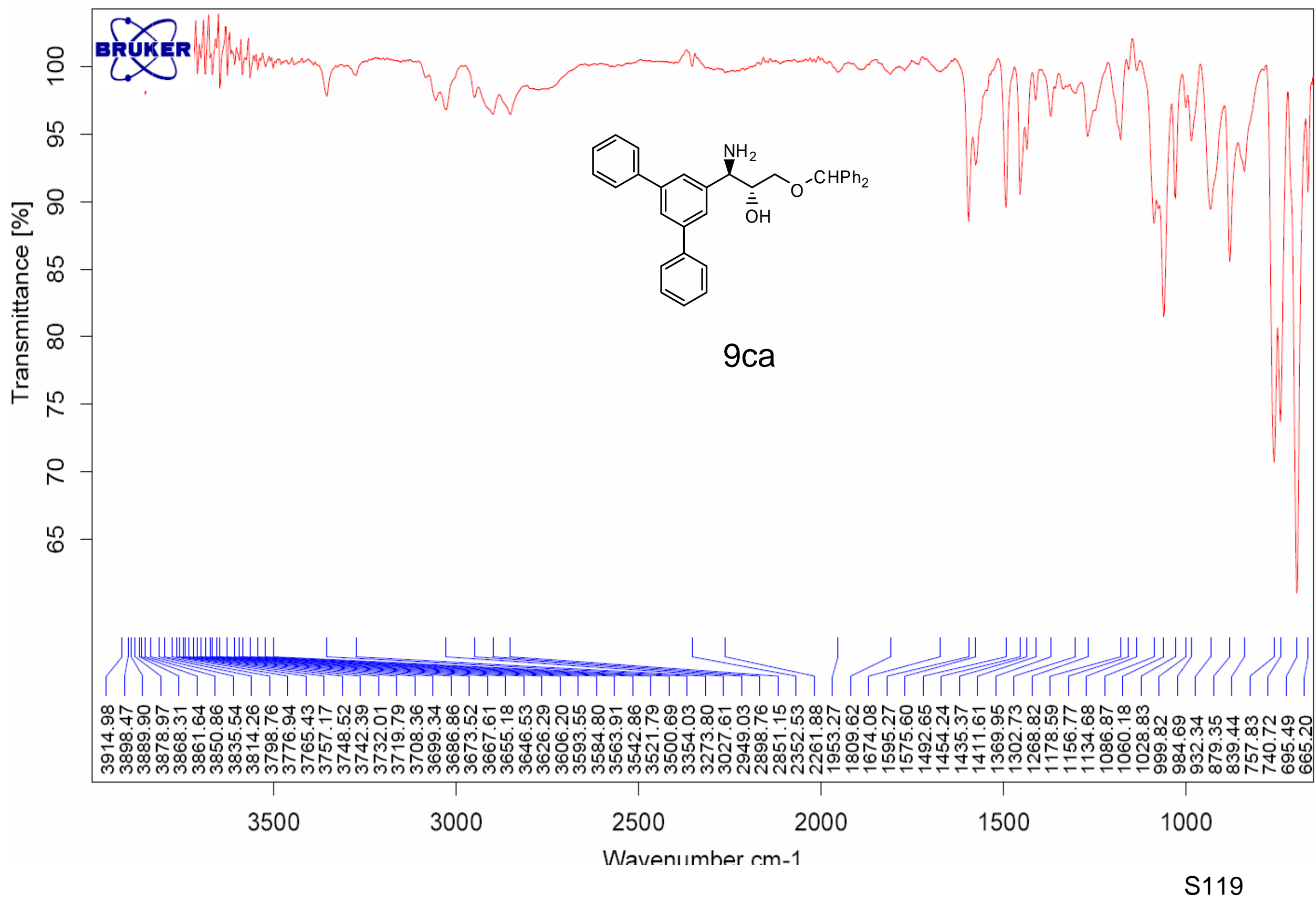




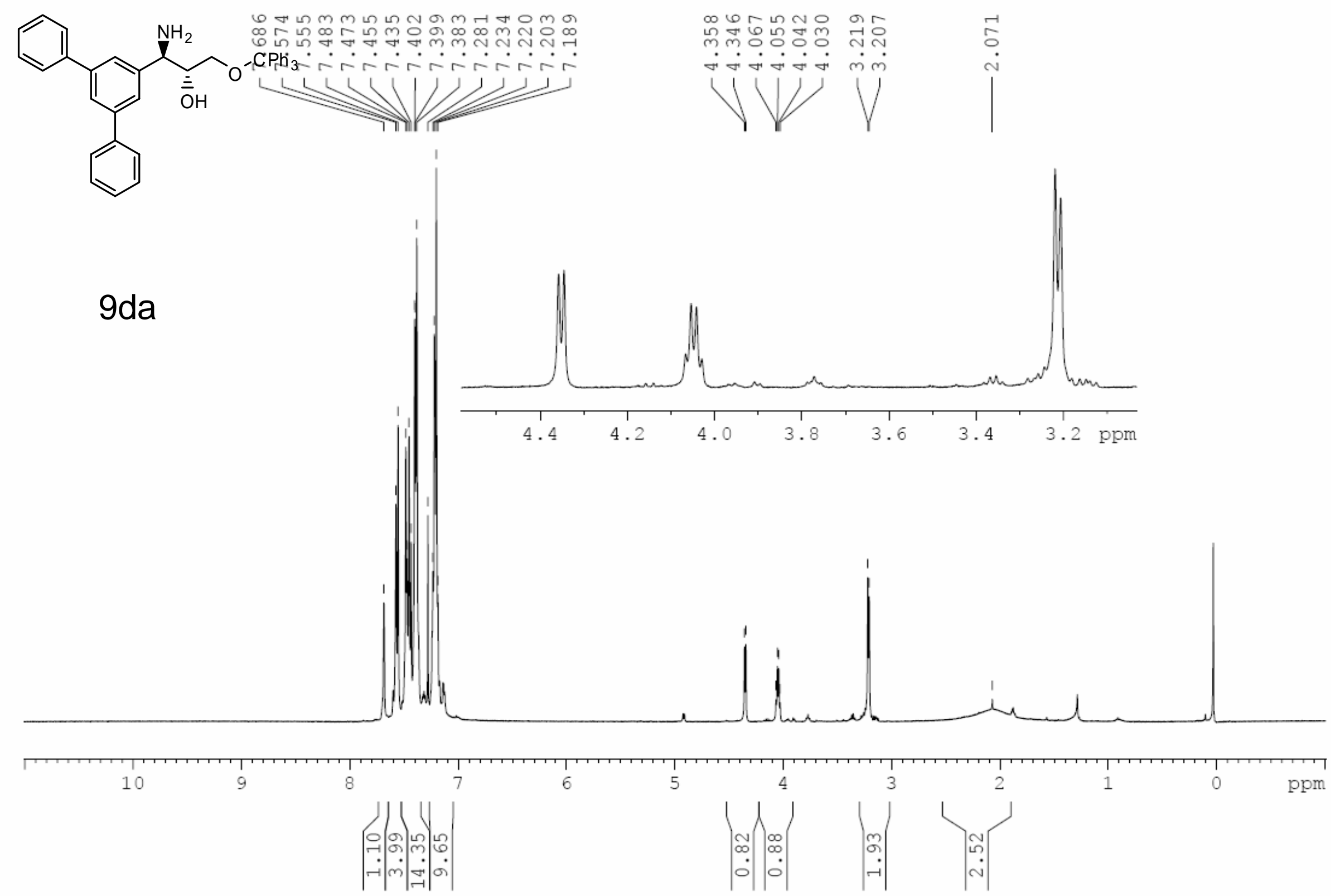




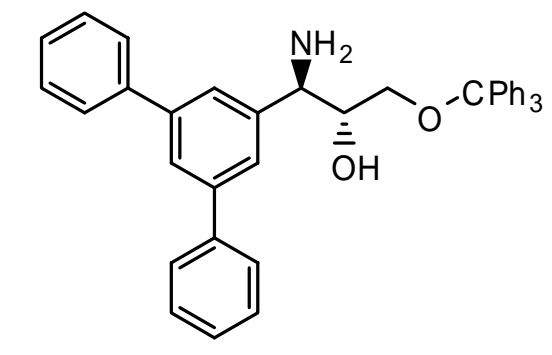

9da
츙ำํํำ

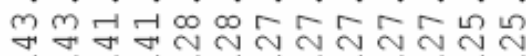

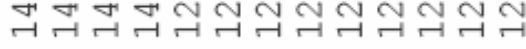

1

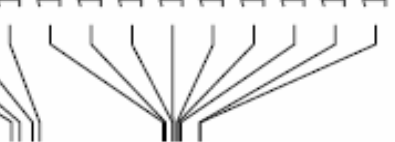

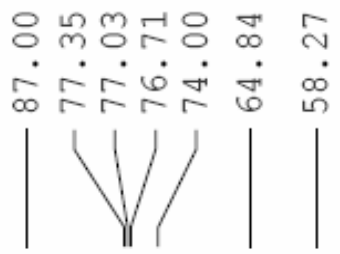

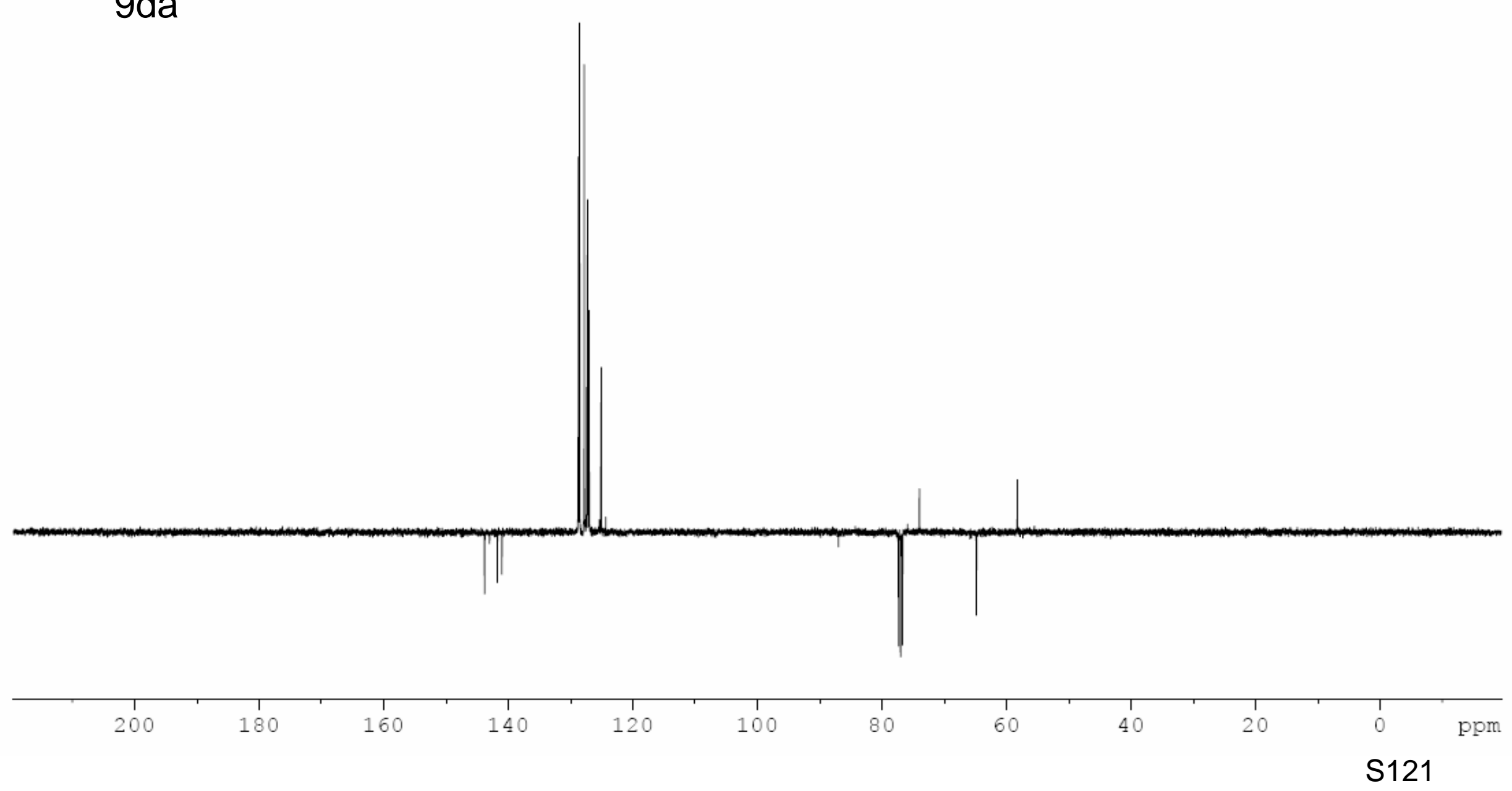




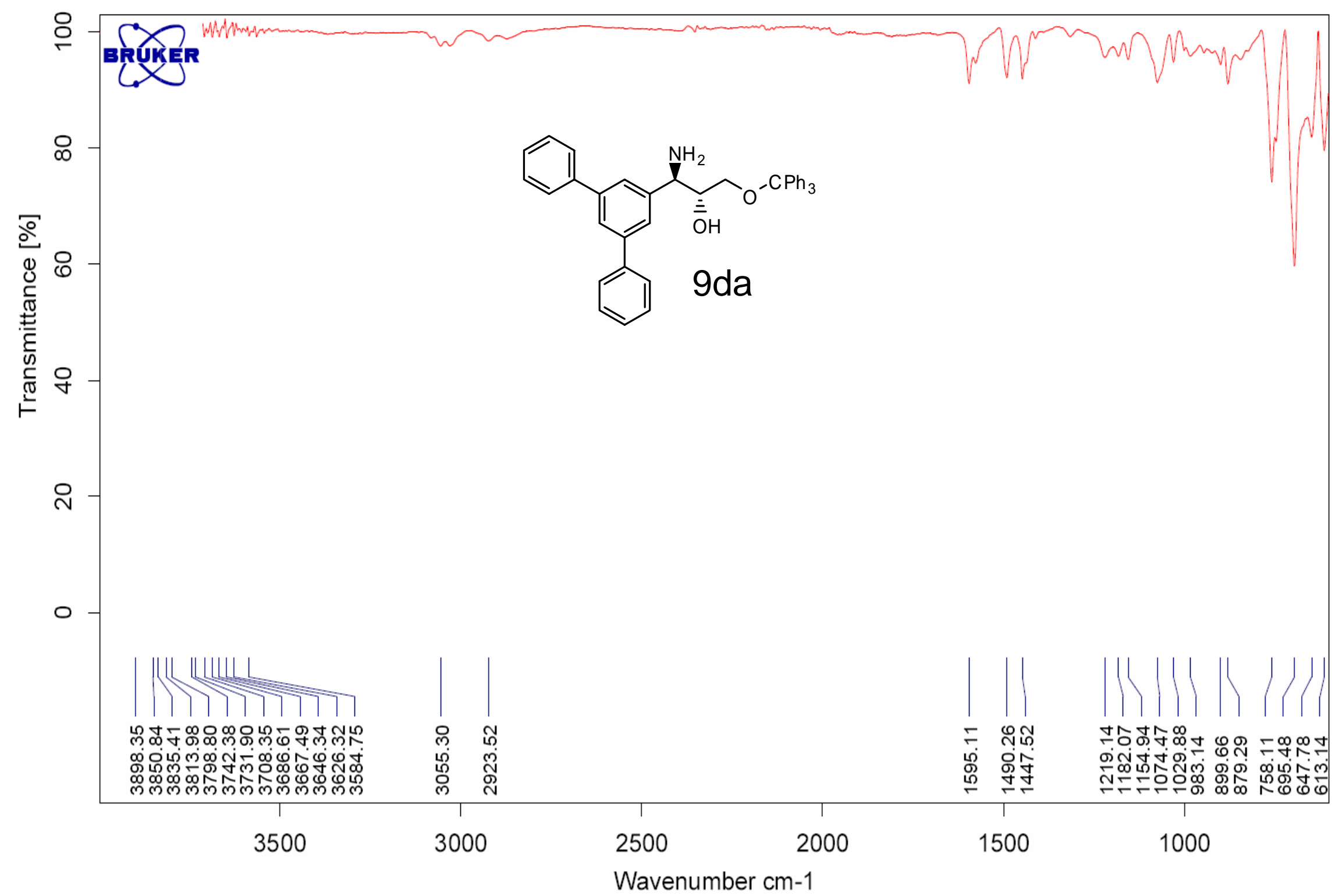




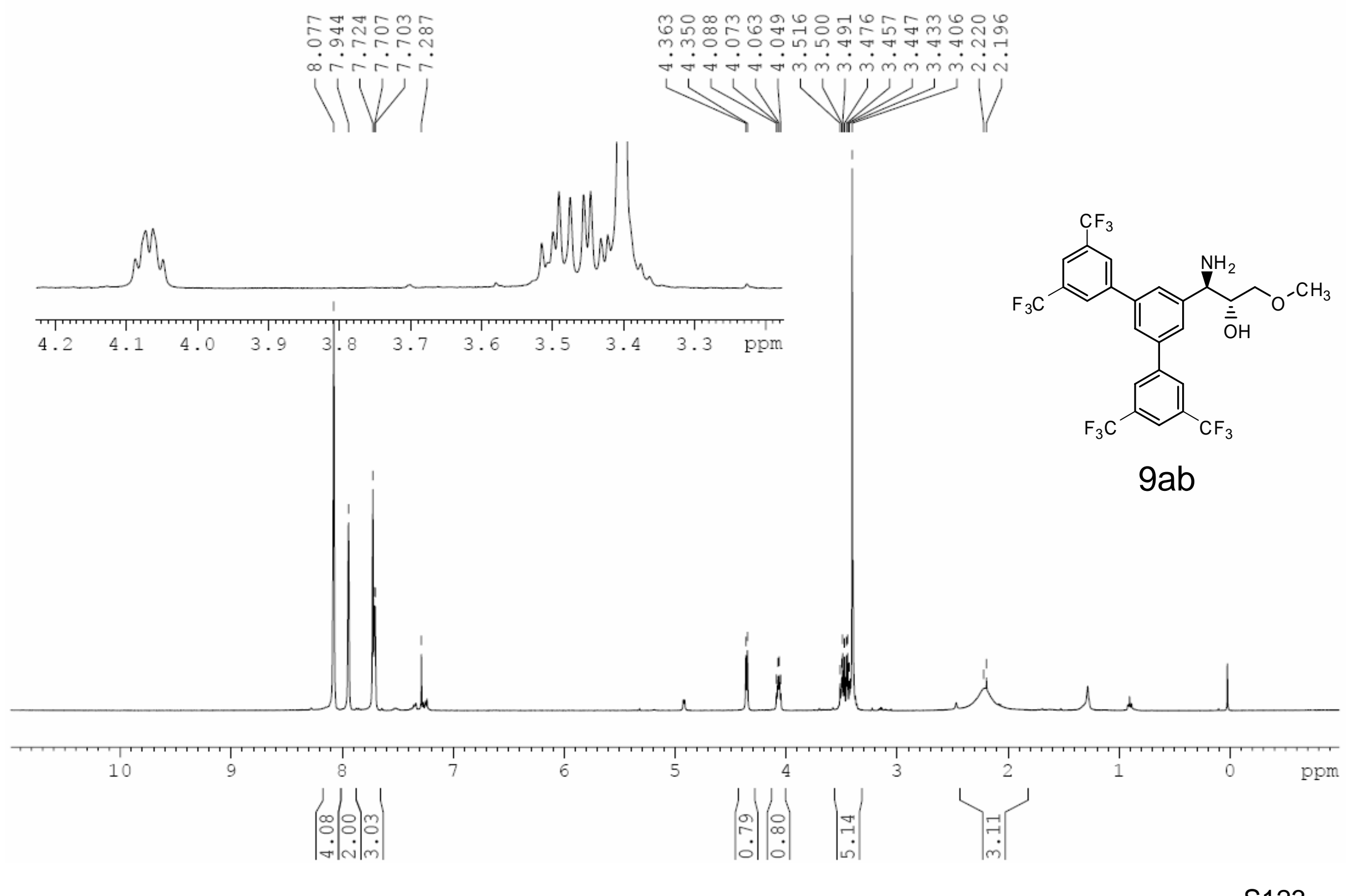




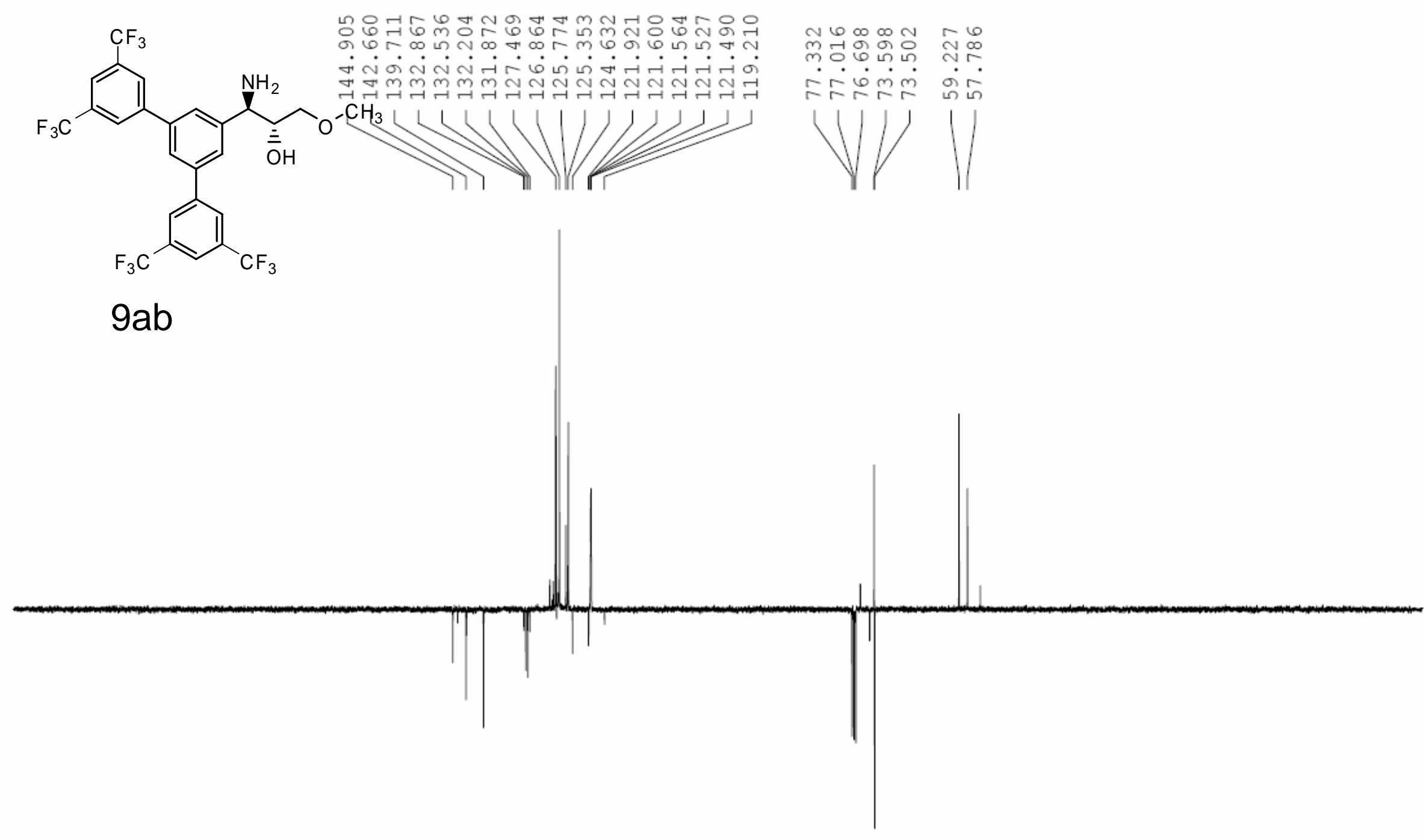

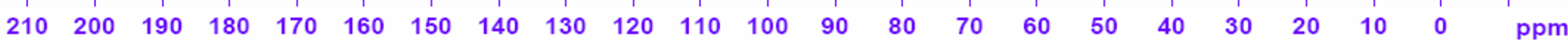




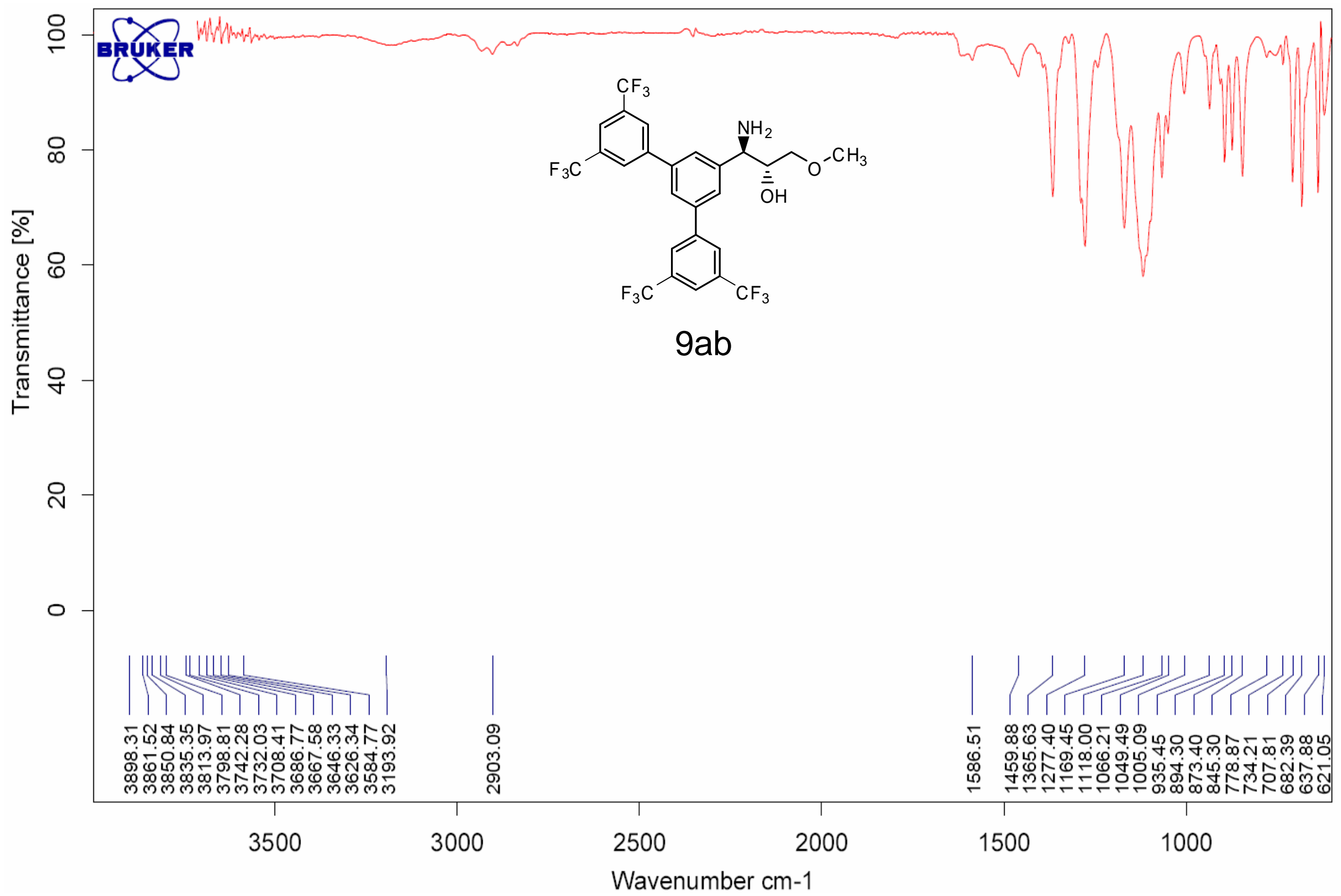




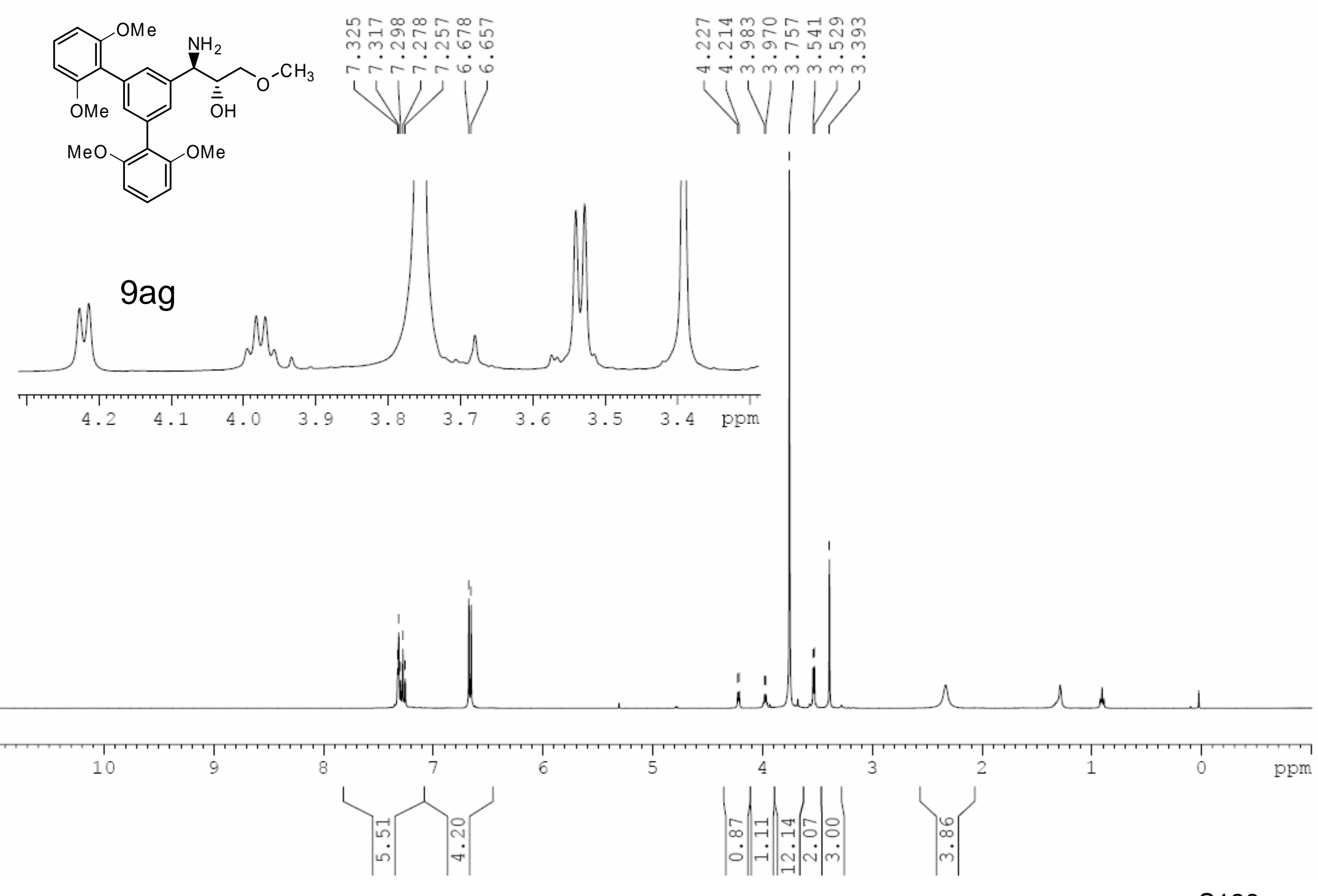




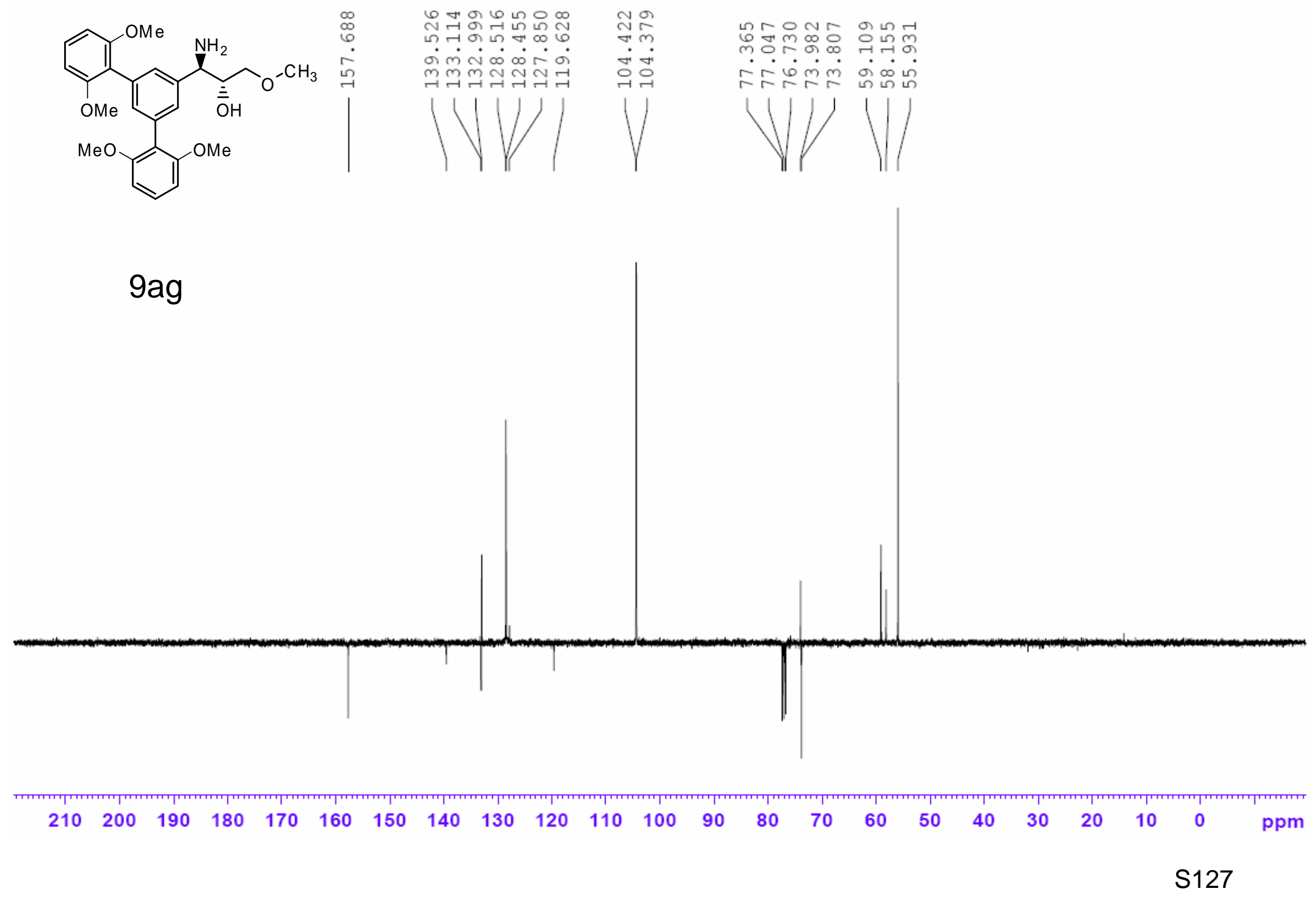




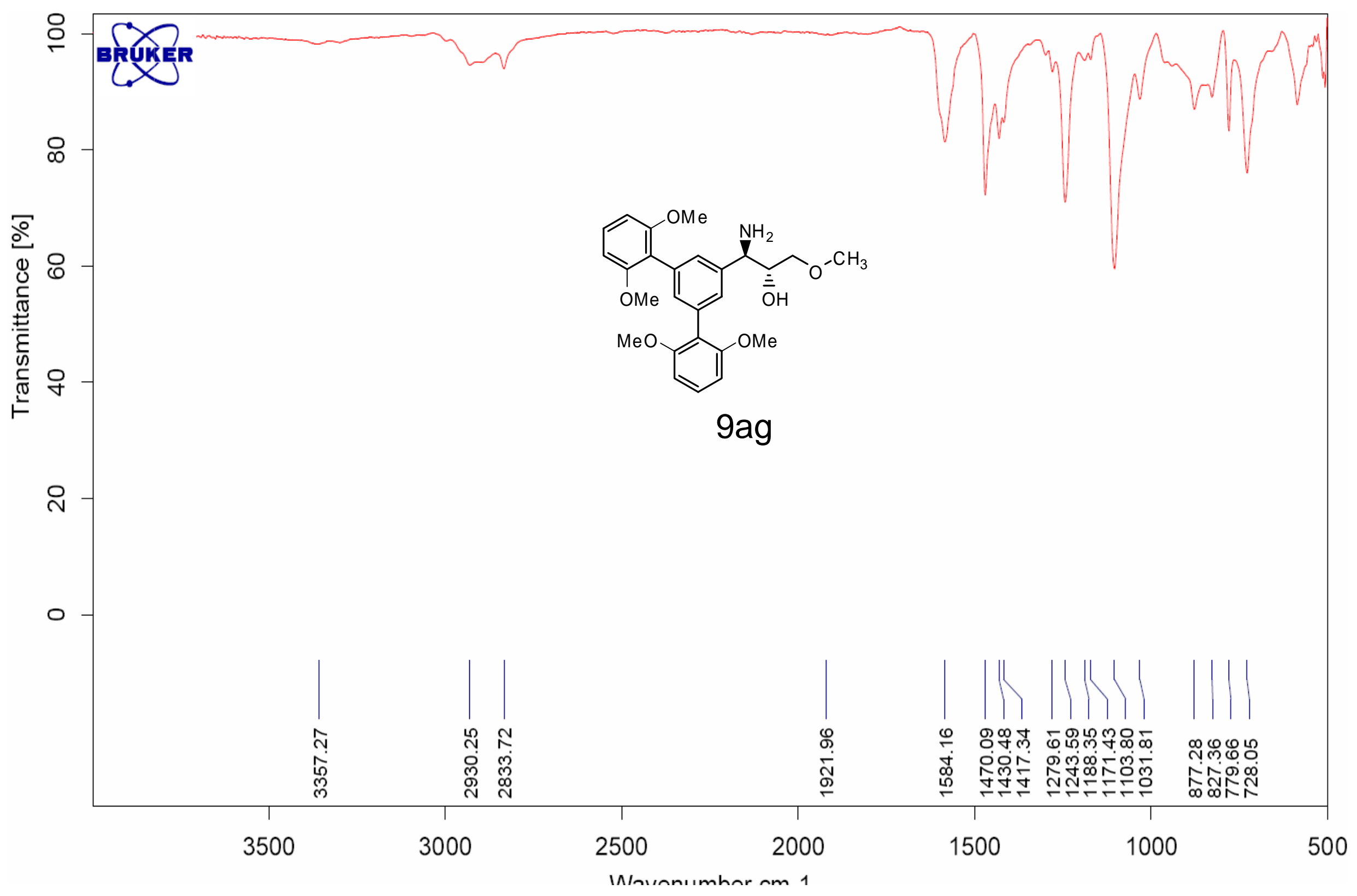




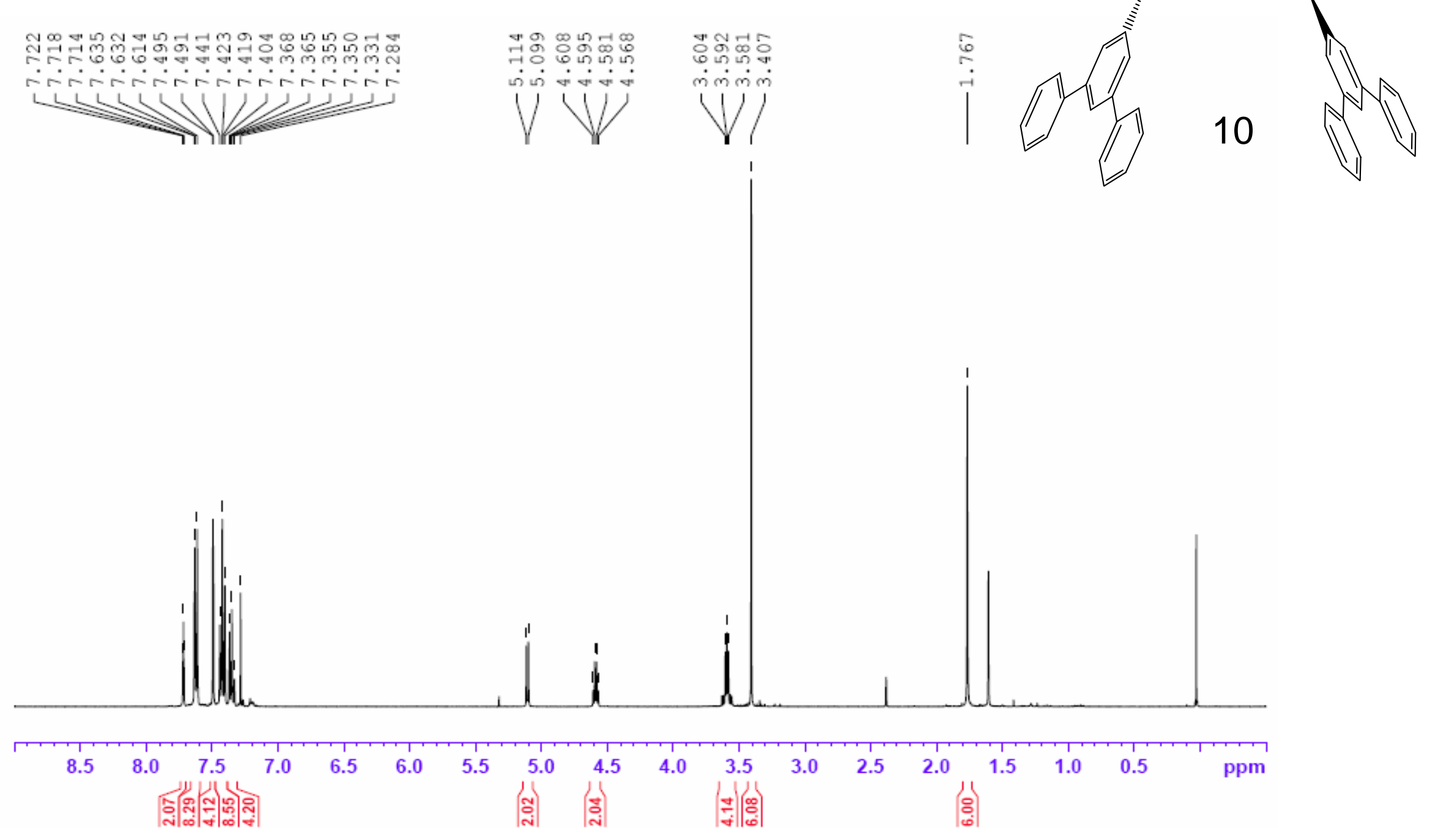




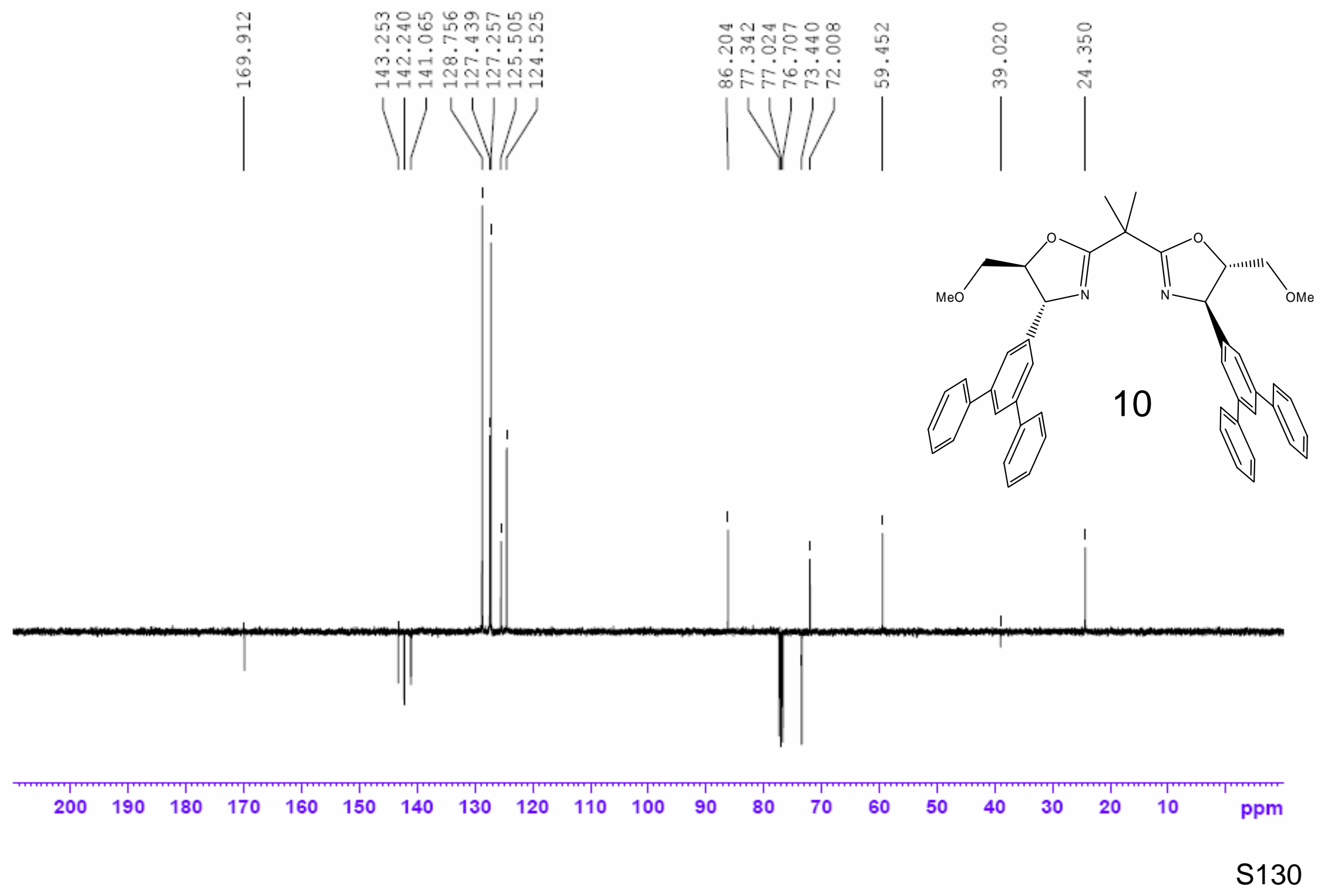




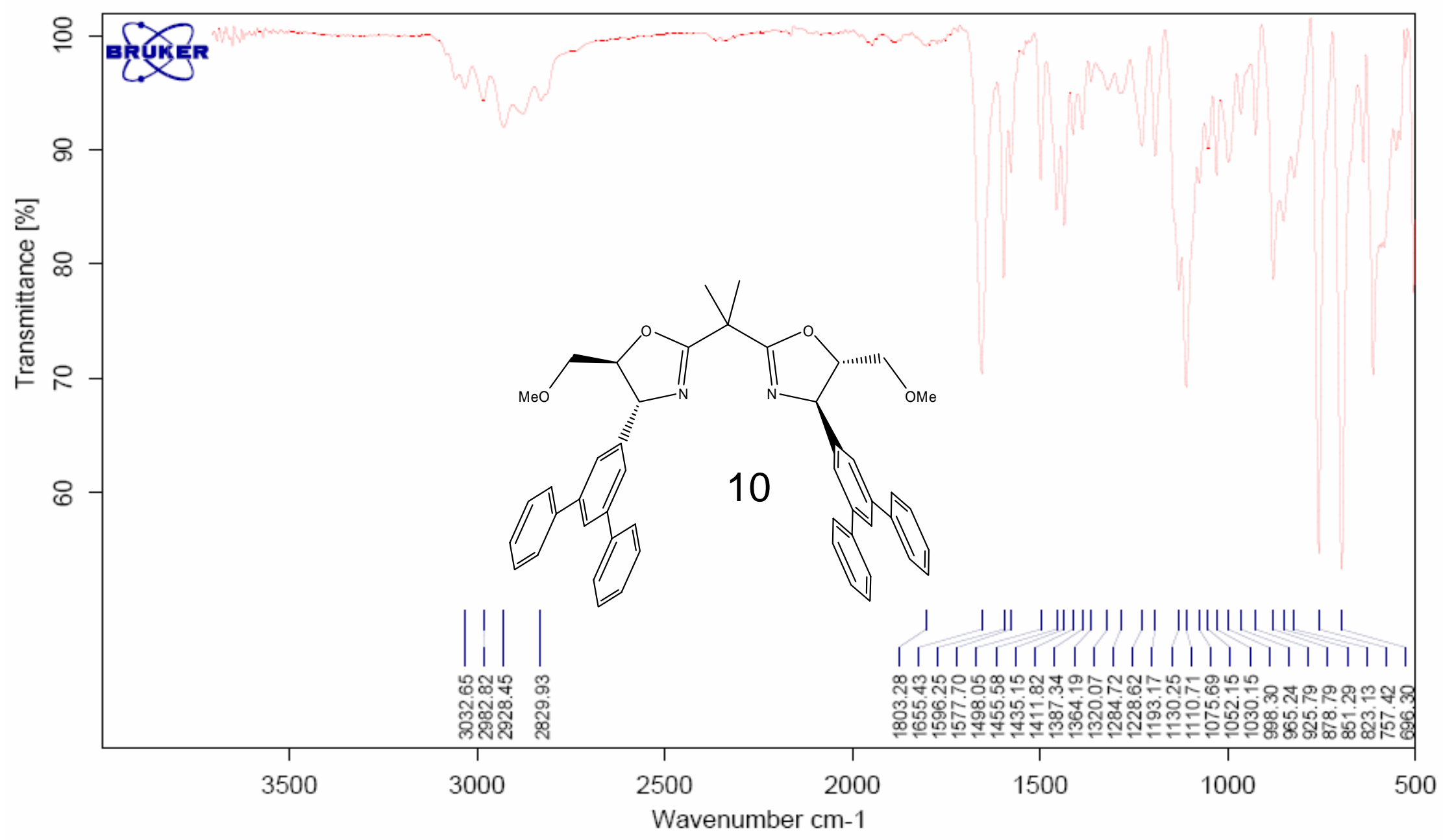

